UNIVERSIDADE DE SÃO PAULO

FFCLRP - DEPARTAMENTO DE PSICOLOGIA

PROGRAMA DE PÓS-GRADUAÇÃO EM PSICOLOGIA

\title{
A relação entre a Educação Infantil e as famílias do campo
}

\section{Luciana Pereira de Lima}

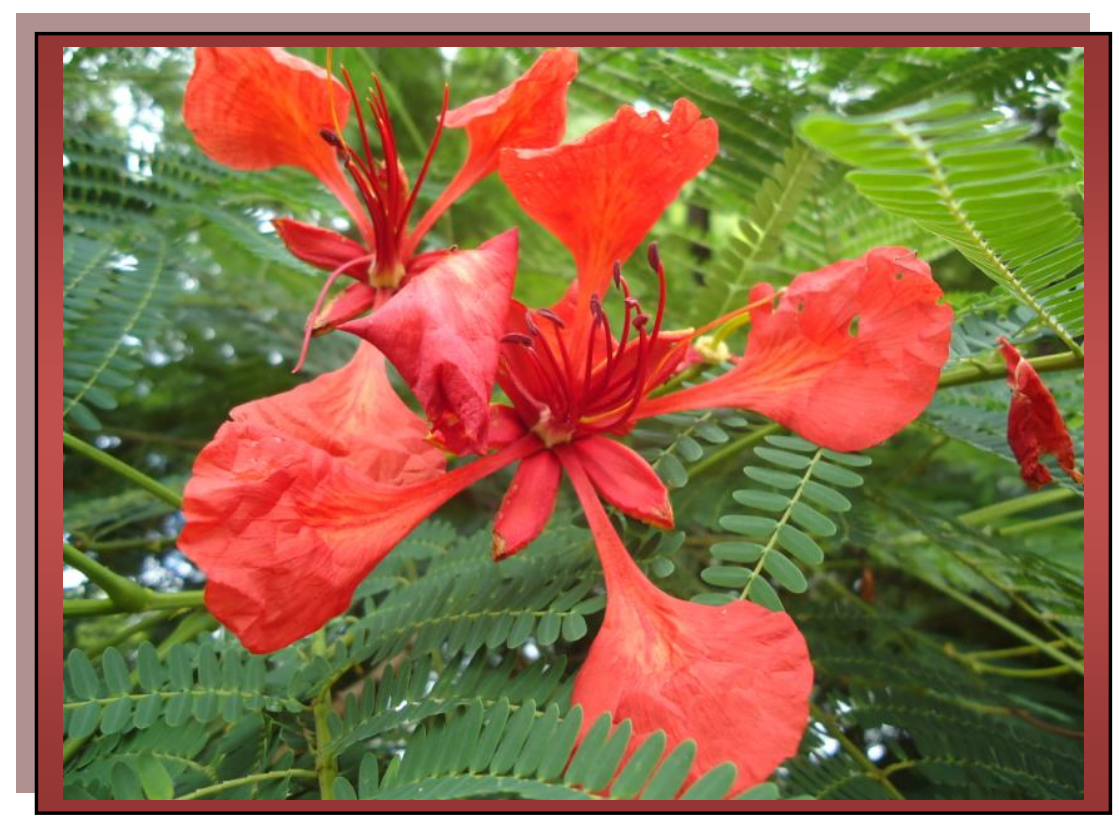

Tese apresentada à Faculdade de Filosofia, Ciências e Letras de Ribeirão Preto da USP, como parte das exigências para a obtenção do Título de Doutor em Ciências, Área: Psicologia.

Ribeirão Preto - SP 

LUCIANA PEREIRA DE LIMA

\section{A relação entre a Educação Infantil e as famílias do campo}

Tese apresentada à Faculdade de Filosofia, Ciências e Letras de Ribeirão Preto da USP, como parte das exigências para a obtenção do Título de Doutor em Ciências.

Área de concentração: Psicologia

Orientadora: Profa. Dra. Ana Paula Soares da Silva

Ribeirão Preto - SP 
As fotos apresentadas no presente trabalho foram tiradas, ao longo da pesquisa, nas instituições de Educação Infantil no campo.

\section{FICHA CATALOGRÁFICA}

Lima, Luciana Pereira de.

A relação entre a Educação Infantil e as famílias do campo. Ribeirão Preto, 2012.

287p. : il.

Tese de Doutorado apresentada à Faculdade de Filosofia, Ciências e Letras de Ribeirão Preto/USP. Área de concentração: Psicologia.

Orientadora: Silva, Ana Paula Soares da.

1. Educação Infantil 2. Pré-Escola 3.Família 4. Rural

5. Educação do Campo 


\section{FOLHA DE APROVAÇÃ̃o}

Luciana Pereira de Lima

A relação entre a Educação Infantil e as famílias do campo

Tese apresentada à Faculdade de Filosofia, Ciências e Letras de Ribeirão Preto da USP, como parte das exigências para a obtenção do Título de Doutor em Ciências. Área de concentração: Psicologia.

Aprovado em:

\section{BANCA EXAMINADORA}

Prof. Dr.:

Instituição:

Prof. Dr.:

Instituição:

Prof. Dr.:

Instituição:

Prof. Dr.:

Instituição:

Prof. Dr.:

Instituição: 

Dedico este trabalho a todos que lutam por uma Educação de qualidade para a nossa infância. Aos profissionais, famílias, crianças que estão no campo, são do campo elou defendem, respeitam e valorizam o campo, suas riquezas, encantos, saberes...

Aos meus pais, meu marido, minha família pelo amor, carinho e apoio ao longo de minha trajetória. Amores eternos! 



\section{AGRADECIMENTOS}

Agradeço primeiramente e especialmente à querida professora Ana Paula. Não há palavras que expressem adequadamente todo respeito, admiração e orgulho que tenho por você! Orientadora, amiga, companheira, que me ensinou o valor da pesquisa e dos grupos de estudo. Que permitiu que vivenciasse de forma apaixonante o Mestrado, o Doutorado, o CINDEDI, o SEITERRA. Que me ensinou e mostrou pelo seu exemplo o valor da ética na academia e na comunidade. Que me permitiu ver e viver a pesquisa de forma articulada com a extensão e o ensino. Sua alegria, paixão, seriedade, compromisso e pleno envolvimento com a educação, com a infância e com o campo nos contagiam e nos ensinam. Sem dúvida, uma pessoa muito especial! Obrigada por tudo!

À querida professora Clotilde, nosso exemplo de pesquisadora e de ser humano. Professora emérita de nossos corações.

Ao CINDEDI, ao SEITERRA, aos filhos da Ana, que permitiriam que vivenciasse a riqueza e amizade deste e neste grupo de pesquisa. Vocês tornaram o Mestrado e o Doutorado um caminho "povoado" e "compartilhado" e nunca "solitário".

Às professoras Jaqueline Pasuch, Zilma de Moraes Ramos de Oliveira e Isabel de Oliveira e Silva pelas inúmeras contribuições dadas no Exame de Qualificação e que auxiliaram grandemente no desenvolvimento da presente tese.

À querida Alda (in memoriam), pelo carinho e pelos encontros aconchegantes nas minhas idas e vindas de Uberlândia para Ribeirão Preto. Você está nos nossos corações.

A todos os profissionais da USP que em algum momento me auxiliaram nesta jornada. Ao Ronie pelo apoio dado ao CINDEDI. 

À Universidade Federal de Uberlândia e, em especial, ao Instituto de Psicologia pelas inúmeras experiências e formações proporcionadas ao longo de minha carreira profissional.

Ao município onde a pesquisa foi realizada, pela oportunidade de realização do estudo e de aprendizagem nas suas diversas instituições de Educação Infantil no campo.

À Escola, aos profissionais e às famílias do campo que participaram da pesquisa. Agradeço a confiança, disponibilidade e seriedade que demonstraram ao longo do estudo. Merecedores de nossa admiração e de nosso respeito pela luta cotidiana na Educação. Na nossa relação fui aprendiz e agradeço pela oportunidade. Muito obrigada!!!

Aos meus amados pais, Cleuton e Fatima, que me ensinaram o valor do respeito, do amor e da Educação, e que me acompanharam com ternura em cada passo realizado. Agradeço ainda pelo exemplo de luta e de amor à vida.

Ao meu amor e marido Leandro, companheiro de várias jornadas, pelo amor, carinho e momentos de alegrias que tornam minha vida mais leve e feliz. O maior encontro de minha vida!

Aos meus amados irmãos, Gustavo e Raquel, pelo constante amor, carinho, companheirismo e amizade.

À Leninha, Horácio, Karla e Jane, pela convivência, carinho e atenção.

Aos meus amados sobrinhos, Henrique, Ana Júllia, Letícia e Gabriel pelas alegrias cotidianas, pelas brincadeiras e abraços que tornam o dia mais alegre.

À minha avó que com sua sabedoria, serenidade e amor me apontou sempre o valor do conhecimento e me ensinou muito sobre a vida.

À minha amiga Telma, pelo carinho e apoio incondicional ao longo do Mestrado e Doutorado. Obrigada pelas nossas conversas e por sua amizade. 

À minha família Lima, Pereira, Martins e Costa por todo o amor e carinho. Aos meus amigos que sempre estiverem ao meu lado, mesmo a distância.

A todos aqueles que me incentivaram e possibilitaram a realização deste trabalho.

Obrigada a todos! 

LIMA, Luciana Pereira de. A relação entre a Educação Infantil e as famílias do campo. 2012. 287 p. Tese (Doutorado) - Faculdade de Filosofia, Ciências e Letras de Ribeirão Preto, Universidade de São Paulo, Ribeirão Preto, 2012.

\section{RESUMO}

A relação dialógica e de proximidade entre a Educação Infantil e as famílias do campo é considerada necessária ao atendimento à criança de 0 a 6 anos, em espaços coletivos. No contexto rural, tal relação pode ser atravessada por diferentes elementos que precisam ser compreendidos por aqueles que almejam uma Educação Infantil no campo voltada à sua realidade e às características de suas crianças e famílias. Diante do reduzido número de estudos na área, realizamos a presente pesquisa que teve como objetivo investigar as significações de profissionais da educação e famílias do campo sobre a relação entre a Educação Infantil e as famílias do campo. Partimos da hipótese de que as significações que compõem o universo semiótico das profissionais e das famílias partilham elementos gerais da matriz sócio-histórica, mas que a relação diferenciada no e com o rural e suas condições materiais de existência circunscreve também diferentes possibilidades de significações, em relações de proximidade e distanciamento. A pesquisa foi realizada em um município de Minas Gerais que possuía 13 Escolas que ofereciam Educação Infantil no campo. Em um primeiro momento da pesquisa, foram realizadas visitas às 13 Escolas, nas quais realizamos observações e entrevistas com 13 gestoras. Os dados construídos nessa fase foram analisados e utilizados para selecionar a Escola que foi foco da pesquisa e que atendia crianças no Ensino Fundamental e na Educação Infantil. Em um segundo momento, tivemos como participantes profissionais desta Escola (1 diretora, 2 vice-diretoras, 1 pedagoga e 2 professoras) e famílias (1 morava em assentamento rural, 2 em casas de uma indústria e 2 em fazendas). Os instrumentos utilizados para a construção dos dados foram: observações e entrevistas. As observações foram realizadas na Escola e nas residências das famílias, e as entrevistas foram realizadas com as 5 famílias e as 6 profissionais da instituição escolar. Para a construção, apresentação e análise dos dados, baseamo-nos na perspectiva teórico-metodológica da Rede de Significações. O material foi sistematizado e analisado em 5 eixos temáticos, a saber: 1) Educação Infantil como (não) demanda das famílias; 2) Objetivos da Educação Infantil no campo; 3) Instrumentos da relação Escola e família; 4) Relação Escola e família e distâncias geográficas no campo; 5) Situações problemáticas na relação Escola e família. A análise dos dados mostrou que a relação diferenciada de profissionais e famílias com o rural contribuía para a construção de significações pelas participantes marcadas por movimentos de aproximações e distanciamentos e que iam ora em direção a elementos da matriz sóciohistórica, ora a elementos da concretude do campo. Identificamos que a relação entre as instituições escolar e familiar no campo investigado era constituída por elementos por vezes semelhantes e por vezes distintos dos encontrados no contexto urbano e em outros contextos rurais. O tipo de rural e suas características geográficas e econômicas, as diversidades das famílias, suas demandas e concepções, as relações de trabalho no campo, as condições de vida parecidas e/ou distintas das urbanas são elementos evidenciados nesta pesquisa e que atravessam a relação Escola e família. As concretudes e características de cada rural, e suas (des)continuidades com outros contextos, emergiram como importantes aspectos a serem considerados e compreendidos por profissionais, gestores e instituições que almejam a melhoria da relação entre a Educação Infantil e as famílias do campo.

Palavras-chave: Educação Infantil. Pré-Escola. Família. Rural. Educação do Campo. 

LIMA, Luciana Pereira de. The relationship between early education and rural families. 2012. 287 p. Thesis (Ph.D.) - School of Philosophy, Sciences and Letters of Ribeirão Preto, University of São Paulo, Ribeirão Preto, 2012.

\begin{abstract}
The dialogic relationship and closeness between families and early childhood education in rural area is considered necessary when referring to child 0-6 years in collective spaces. In the rural context, such relationship can be traversed by different elements which need to be understood by those who aim child education in rural area focused on the children and their families' reality and characteristics. Given the small number of studies in the area, we conducted the present study aimed to investigate the meanings of education professionals and field families on the relationship between early childhood education and rural families. The assumption is that the meanings that make up the semiotic universe of professionals and families share common elements of socio-historical matrix, but with a different relation in and with the countryside and its material conditions of existence also circumscribes different possible meanings in relations of proximity and distance. The research was conducted in a municipality of Minas Gerais, with 13 schools that offered early education in rural areas. At first in the research, visits were made to the 13 schools in which observations and interviews were conducted with 13 managers. The data constructed in this phase were analyzed and used in order to select the focus School of the research, serving children in Elementary Education and Early Childhood Education. In a second step, the selected participants of the interview were professionals of this School (1 director, two vice-directors, one educator, and 2 teachers) and families ( 1 lived in a rural settlement, 2 in homes in an industry, and 2 in farms). The instruments used for the data construction were: observations and interviews. The observations were conducted in the School and at the families' homes and the interviews were conducted with five families and six school professionals. For the data construction, presentation and analysis, we rely on theoretical and methodological perspective network of meanings. The material was systematized and analyzed in 5 thematic areas, namely: 1) Early Childhood Education as (not) family demand, 2) Objectives of Early Childhood Education in the field, 3) Instruments of school and family relationship; 4) School and family relationship and geographical distances in the field, 5) problematic situations regarding School and family. Data analysis showed that the different ratio of professionals and families with the rural contributed to the construction of meanings by participants marked by movements of closeness and distance and they would go once toward elements of socio-historical matrix, once towards elements of concreteness in the field. We found that the relationship between school and familiar institutions in the investigated field consisted sometimes by similar and sometimes distinct elements from those found in the urban context and in other rural ones. The rural kind and its geographical and economic characteristics, families' diversity, their demands and ideas, labor relations in the countryside, living conditions similar and / or different from urban elements are highlighted in this research and which cross the school and family relation. The concreteness and characteristics of each rural, and their (dis) continuities with other contexts, have emerged as important aspects to be considered and understood by professionals, managers and institutions who want to improve the relationship between families and early childhood education in the rural areas.
\end{abstract}

Keywords: Early Childhood Education; Preschool; Family; Rural; Education in Rural Area. 



\section{LISTA DE SIGLAS}

CINDEDI - Centro de Investigações sobre o desenvolvimento humano e Educação Infantil.

ECA - Estatuto da criança e do adolescente.

EEEICs - Escolas Exclusivas de Educação Infantil localizadas no campo.

EEFEICs - Escolas de Ensino Fundamental e que ofereciam Educação Infantil no campo.

EF - Ensino Fundamental.

EI - Educação Infantil.

EMEI - Escola Municipal de Educação Infantil.

IBGE - Instituto Brasileiro de Geografia e Estatística.

INEP - Instituto Nacional de Estudos e Pesquisas Educacionais Anísio Teixeira.

LDB - Lei de Diretrizes e Bases da Educação.

MST - Movimento de Trabalhadores Rurais Sem-terra.

ONG - Organização não governamental.

RedSig - Rede de Significações.

SEITERRA - Subjetividade, Educação e Infância nos Territórios Rurais e da Reforma Agrária. 



\section{LISTA DE QUADROS}

Quadro 1 - Cargo das entrevistadas nas instituições que ofereciam, no município, Educação Infantil no campo.

Quadro 2 - Cronograma de execução da pesquisa .90

Quadro 3 - Nomes fictícios utilizados para identificar as profissionais da Escola Flamboyant

Quadro 4 - Nomes fictícios utilizados para identificar membros das famílias do campo

Quadro 5 - Número de entrevistas realizadas e analisadas

Quadro 6 - Instituições de Educação Infantil da cidade no município, no ano de 2010 100

Quadro 7 - Instituições de Educação Infantil do campo no município, no ano de 2010 100

Quadro 8 - Caracterização das EEEICs 102

Quadro 9 - Ocupação das famílias atendidas pelas EEEICs 103

Quadro 10 - Caracterização das EEFEICs 104

Quadro 11 - Dados sobre a Educação Infantil nas EEFEICs 105

Quadro 12 - Ocupação das famílias atendidas pelas EEFEICs 107

Quadro 13 - Elementos que influenciam a demanda por EI - Relatos das profissionais 130

Quadro 14 - Critérios para avaliar a necessidade de EI no campo - Relatos das profissionais. 131

Quadro 15 - Elementos que influenciam a demanda por EI - Relatos das famílias..... 142

Quadro 16 - Critérios para avaliar a necessidade de EI no campo - Relatos das famílias 143

Quadro 17 - Elementos que influenciam a demanda por EI - Relatos das profissionais e famílias..... 145

Quadro 18 - Critérios para avaliar a necessidade de EI no campo - Relatos das profissionais e famílias

Quadro 19 - Objetivos da Educação Infantil - Relatos das profissionais 159

Quadro 20 - Objetivos da Educação Infantil - Relatos das famílias. .165

Quadro 21 - Objetivos da Educação Infantil - Relatos das profissionais e famílias 166

Quadro 22 - Instrumentos da relação Escola e família - Relatos das profissionais 181

Quadro 23 - Instrumentos da relação Escola e família - Relatos das famílias 193

Quadro 24 - Instrumentos da relação Escola e família (Finalidades) - Relatos das profissionais e famílias. 

Quadro 25 - Como ocorria a relação Escola e famílias com o uso dos instrumentos - Relatos das profissionais e das famílias.

Quadro 26 - Elementos que se associam à distância geográfica e influenciam a ida da família à Escola

- Relatos das profissionais

Quadro 27 - Elementos que se associam à distância geográfica e influenciam a ida da família à Escola

- Relatos das famílias

Quadro 28 - Elementos que se associam à distância geográfica e influenciam a ida da família à Escola

- Relatos das profissionais e famílias

Quadro 29 - Elementos envolvidos na ocorrência das situações problemáticas - Relatos das profissionais

Quadro 30 - Elementos que dificultavam a resolução das situações problemáticas - Relatos das profissionais

Quadro 31 - Elementos envolvidos na ocorrência das situações problemáticas - Relatos das famílias

Quadro 32 - Elementos que dificultavam a resolução das situações problemáticas - Relatos das famílias.

Quadro 33 - Elementos envolvidos na ocorrência das situações problemáticas - Relatos das profissionais e famílias.

Quadro 34 - Elementos que dificultavam a resolução das situações problemáticas - Relatos das profissionais e famílias. 



\section{CAPÍTULO 2 - ELEMENTOS DA MATRIZ SÓCIO-HISTÓRICA}

2.1. A Educação Infantil no Brasil: elementos históricos da complementaridade do cuidado e educação da criança entre Creches/Pré-escolas e famílias.

2.3 A relação entre a Educação Infantil e as famílias do campo e os objetivos da pesquisa.....

CAPÍTULO 3 - METODOLOGIA

3.1. Os instrumentos da pesquisa e o pesquisador.

3.2. A construção do corpus da pesquisa......

3.3. Os participantes da pesquisa.

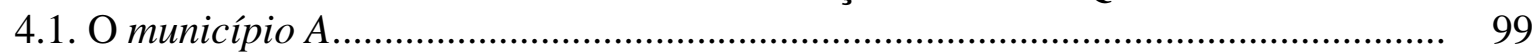

4.2. A Educação Infantil no campo do município A .................................................. 101

4.3. A Escola Flamboyant.................................................................................. 108

4.4. As famílias atendidas pela Escola Flamboyant e participantes da pesquisa............ 109

\section{CAPÍTULO 5 - A RELAÇÃO ENTRE A ESCOLA FLAMBOYANT E AS} FAMÍLIAS DO CAMPO.

5.1. A Educação Infantil como (não) demanda das famílias do campo.......................... 118

5.2. Objetivos da Educação Infantil no campo para as crianças/famílias do campo...... 152

5.3. Os instrumentos da relação entre a Escola Flamboyant e as famílias do campo..... 172

5.4. A relação Escola e famílias e as distâncias geográficas no campo........................... 201

5.5. Situações problemáticas na relação entre a Escola Flamboyant e as famílias do campo. 

CAPÍTULO 6 - DISCUSSÃO.

CAPÍTULO 7 - CONSIDERAÇÕES FINAIS

REFERÊNCIAS

APÊNDICES.

279 



\section{Apresentação}

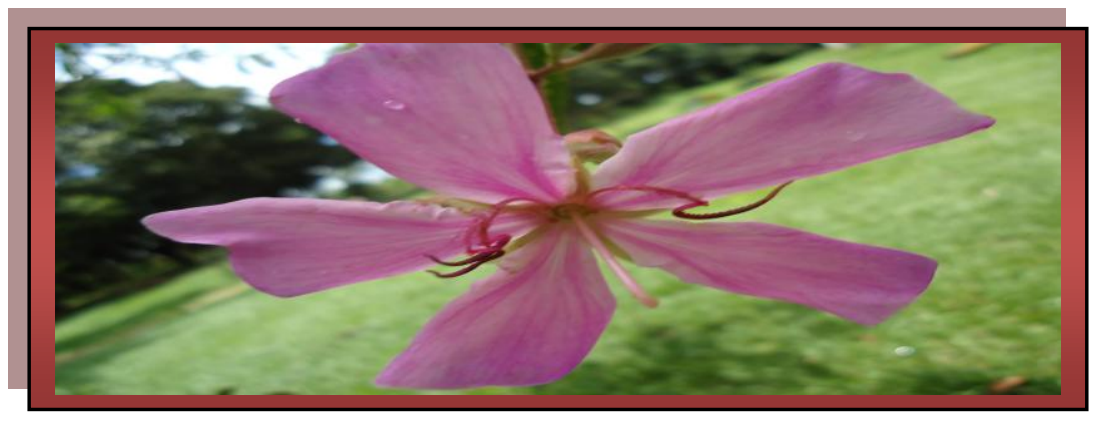





\section{TECENDO A MANHÃ}

\section{João Cabral de Melo Neto}

Um galo sozinho não tece uma manhã: ele precisará sempre de outros galos.

De um que apanhe este grito que ele e o lance a outro; de um outro galo que apanhe o grito de um galo antes e o lance a outro; e de outros galos que com muitos outros galos se cruzem

os fios de sol de seus gritos de galo, para que a manhã, desde uma teia tênue, se vá tecendo, entre todos os galos.

E se encorpando em tela, entre todos, se erguendo tenda, onde entrem todos, se entretendo para todos, no toldo (a manhã) que plana livre de armação.

A manhã, toldo de um tecido tão aéreo que, tecido, se eleva por si: luz balão. 



\section{APRESENTAÇÃO}

Começo o presente trabalho apresentando o poema Tecendo a manhã de João Cabral de Melo Neto, utilizado pela professora Maria Clotilde Rossetti-Ferreira na Introdução do livro Rede de Significações e o estudo do desenvolvimento humano, organizado por esta pesquisadora juntamente com as professoras Katia de Souza Amorim, Ana Maria Almeida Carvalho e Ana Paula Soares da Silva.

Ao iniciar a Introdução do livro sobre a Rede de Significações (RedSig) com o poema Tecendo a manhã, que nos aponta para o caráter coletivo e dialógico das produções humanas, Maria Clotilde Rossetti-Ferreira indica como a perspectiva teórico-metodológica da RedSig, que é discutida na referida publicação e adotada nesta pesquisa, "vem sendo tecida a múltiplas mãos, em um trabalho conjunto de vários anos" (ROSSETTI-FERREIRA; AMORIM; SILVA; CARVALHO, 2004, p. 15) pelos membros do Centro de Investigações sobre Desenvolvimento Humano e Educação Infantil (CINDEDI) e por outros profissionais do país, a partir de diversos debates que permitem o aprofundamento dessa perspectiva teóricometodológica constituída por consensos e contradições.

O presente trabalho de doutorado está vinculado ao CINDEDI e, mais especificamente, a um de seus subgrupos, o SEITERRA: Subjetividade, Educação e Infância nos Territórios Rurais e da Reforma Agrária, e adota essa perspectiva e postura em relação à construção do conhecimento. João Cabral de Melo Neto afirma que um galo sozinho não tece uma manhã. Reconhecemos que uma pesquisadora sozinha não tece um trabalho que se quer científico: este é sempre composto de diversas vozes e olhares. Vozes e olhares daqueles que encontramos na nossa revisão de literatura (em livros, artigos, dissertações, teses e outras publicações), em diversos momentos de discussão de nosso estudo e nos grupos de pesquisa.

A própria temática da presente pesquisa emergiu da inserção no CINDEDI/SEITERRA, indo ao encontro de interesses e vivências ocorridas em minha trajetória ao longo da Graduação e Mestrado em Psicologia. Durante e após o curso de Graduação em Psicologia, realizado na Universidade Federal de Uberlândia - UFU, estive envolvida em atividades de extensão e pesquisa em territórios rurais. Avalio que minha vivência nesses contextos, além de trazer importantes aprendizagens referentes ao campo, foi de fundamental relevância para que me aproximasse da perspectiva teórica com a qual dialogo atualmente: a perspectiva histórico-cultural. Até então me embasava na perspectiva cognitivista que não mais respondia a minhas perguntas de pesquisadora. Penso que esta foi uma conquista importante deste período de trabalho. 
Foi a perspectiva teórica que, em um primeiro momento, aproximou-me do CINDEDI. Por isso, considero que, de certa forma, "o campo levou-me ao CINDEDI/SEITERRA". E, integrando-me ao CINDEDI, realizei o Mestrado. No Mestrado, investiguei sentidos e práticas da Educação Infantil diante da violência doméstica contra a criança e ali também já se encontrava o interesse pelas questões da relação família-Creche/Pré-escola. Na ocasião, contudo, as instituições investigadas eram localizadas em área urbana.

No Doutorado, propomos dar continuidade ao estudo da relação entre a Educação Infantil e famílias, agora voltando-nos para o contexto da Educação Infantil nos territórios rurais. A temática da Educação Infantil em contextos rurais aos poucos vem sendo aprofundada pelo SEITERRA, a partir de diferentes olhares. No exercício de aproximação com este tema e contexto, a relação com as famílias constitui-se em necessária mirada. Neste cenário, o presente trabalho de Doutorado tem como objetivo investigar as significações de profissionais da educação e de famílias do campo sobre a relação entre a Educação Infantil e as famílias do campo.

Como afirmei anteriormente, ao falar da minha inserção no Mestrado, considero que, de certa forma, "o campo levou-me ao CINDEDI/SEITERRA" e hoje penso que "o CINDEDI/SEITERRA levou-me ao campo" em uma condição tão singular e intensa, que é a de doutoranda.

Dessa forma, é com prazer que vimos neste momento compartilhar o presente trabalho. No capítulo 1, realizamos a Introdução ao mesmo para o leitor, apresentando os fundamentos teórico-metodológicos que guiaram o desenvolvimento do estudo, bem como a escolha pelo formato de apresentação escrita desta pesquisa.

No capítulo 2, inicialmente, optamos por apresentar e discutir elementos históricos da complementaridade do cuidado e educação da criança entre Creches/Pré-escolas e famílias no nosso país. Falarmos desta história é falarmos da história da relação entre a Educação Infantil e as famílias brasileiras. Discutimos ainda, nesta parte do trabalho, outros elementos da matriz sócio-histórica e que estão relacionados ao nosso objeto de investigação, tais como leis, publicações nacionais e estudos relativos à temática da pesquisa, e apresentamos os objetivos e a tese. No presente estudo, partimos da hipótese/tese de que as significações que compõem o universo semiótico dos profissionais da educação e das famílias do campo partilham elementos da matriz sócio-histórica, mas que a relação diferenciada no e com o rural e suas condições materiais de existência circunscrevem também diferentes possibilidades de significações, em relações de proximidade e distanciamento. Interessa-nos investigar este 
processo e compreender os elementos que compõem e caracterizam a relação família e Escola no contexto particular do rural.

No capítulo 3, discutimos aspectos da metodologia do trabalho, tais como: os instrumentos utilizados na construção dos dados, a construção do corpus da pesquisa, os participantes da pesquisa e os procedimentos de análise dos dados. Conforme iremos mencionar neste capítulo, tivemos, dentre os participantes da pesquisa, famílias do campo. Cabe ressaltar que, neste trabalho, partimos da concepção de família indicada por Casey (1992): uma unidade não apenas residencial, mas também econômica, jurídica e moral na qual os membros se identificam e mantêm envolvimento emocional. Utilizaremos o termo famílias do campo para nos referirmos às famílias que residem na área denominada como rural pelo município no qual o estudo foi desenvolvido ${ }^{1}$. No capítulo 4 , buscamos apresentar elementos mais amplos dos contextos nos quais a pesquisa foi realizada, a saber: o município, a Escola no campo e as famílias do campo.

Dando continuidade ao trabalho, no capítulo 5, procuramos apresentar as significações construídas por profissionais da educação e famílias do campo, ao longo da pesquisa, sobre a relação entre a Educação Infantil no campo e as famílias. Propomos ainda compreender e indicar os movimentos de aproximações e distanciamentos de tais significações.

No capítulo 6, buscamos retomar, sintetizar e discutir dados construídos ao longo do estudo, em diálogo com os objetivos e tese estabelecidos na investigação. No capítulo 7, realizamos as considerações finais do trabalho.

\footnotetext{
${ }^{1}$ Utilizamos, ao longo do trabalho, o termo "família rural" como sinônimo de "família do campo". É importante salientar que a literatura científica apresenta diversos debates em torno da categoria "camponês", refletindo sobre a adequação ou não de seu uso para o momento histórico atual e para o caso brasileiro, não existindo portanto um consenso entre estudiosos da área (SHANIN, 2005; MARQUES, 2008; BERNSTEIN, 2011).
} 


\section{CAPÍTULO}

1

\section{INTRODUÇÃO}

FUNDAMENTOS TEÓRICO-METODOLÓGICOS DA PESQUISA

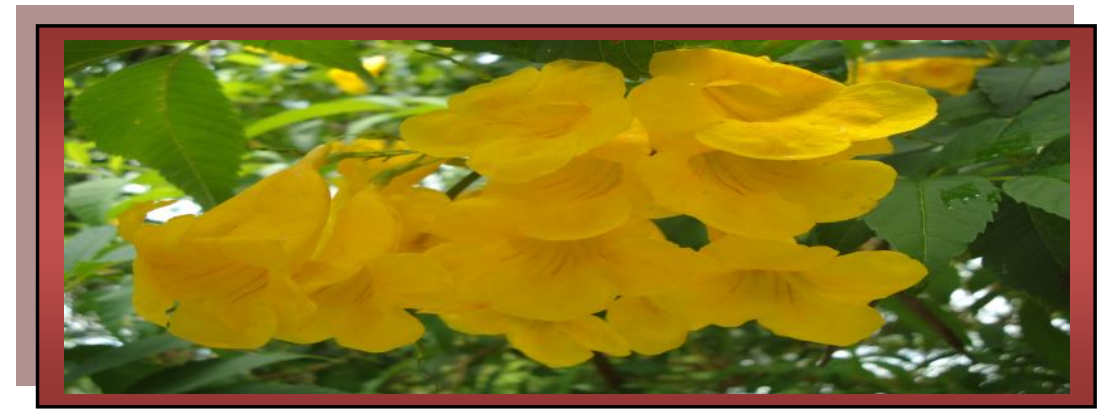





\section{INTRODUÇÃO \\ FUNDAMENTOS TEÓRICO-METODOLÓGICOS DA PESQUISA}

O presente estudo se insere em uma das linhas de pesquisa do CINDEDI, vinculado a um de seus subgrupos, o SEITERRA. O CINDEDI, conforme discutido em diversos trabalhos (AMORIM; VITORIA; ROSSETTI-FERREIRA, 2000; ROSSETTI-FERREIRA; AMORIM; SILVA， 2000; ROSSETTI-FERREIRA; AMORIM; SILVA; CARVALHO， 2004; ROSSETTI-FERREIRA; AMORIM; SILVA; OLIVEIRA，2008; DARAHEM; SILVA; COSTA, 2009), a partir da inserção em instituições de Educação Infantil e em instituições de abrigamento e acolhimento da criança, vem buscando desenvolver um referencial teóricometodológico para o estudo do desenvolvimento humano e para a investigação de processos psicológicos/sociais/culturais, denominado de Rede de Significações (RedSig).

A RedSig vem sendo construída em diálogo com autores histórico-culturais, como Lev Semenovitch Vygotsky, Henri Paul Hyacinthe Wallon e Mikhail Mikhailovich Bakhtin. Esta perspectiva teórico-metodológica defende a centralidade dos processos de significação para a constituição e desenvolvimento humanos. Conforme afirmam as autoras da RedSig, "como o próprio nome da perspectiva faz alusão, posicionamo-nos no mesmo campo de ideias daqueles que acreditam na natureza discursiva e no caráter semiótico da constituição humana" (ROSSETTI-FERREIRA; AMORIM; SILVA; CARVALHO, 2004, p. 24).

Dentre as diversas possibilidades de apropriação dos conceitos da RedSig na construção da pesquisa, alguns aspectos instrumentalizam a discussão do objeto de estudo deste trabalho: os processos de significação, os contextos ou cenários, a matriz sóciohistórica.

Na perspectiva da RedSig os processos de significação são fundamentais para o entendimento das interações e desenvolvimento humano. Envolvem a construção de significados e sentidos.

Para Vygotsky (2009), o significado de uma palavra é um fenômeno tanto do pensamento como da linguagem, sendo a unidade de análise para o estudo da consciência humana. $\mathrm{O}$ autor destaca que o significado modifica-se ao longo da vida de uma pessoa, não sendo, portanto, estático, como afirmava a vertente associacionista do estudo do pensamento e da linguagem. 
Vygotsky, partindo da concepção de dinamicidade do significado e baseando-se nas discussões do psicólogo francês Frederic Paulham sobre a temática, formula e apresenta o conceito de sentido, assim por ele definido:

(...) O sentido de uma palavra é a soma de todos os fatos psicológicos que ela desperta em nossa consciência. Assim, o sentido é sempre uma formação dinâmica, fluida, complexa, que tem várias zonas de estabilidade variada. $\mathrm{O}$ significado é apenas uma dessas zonas de sentido que a palavra adquire no contexto de algum discurso e, ademais, uma zona mais estável, uniforme e exata. Como se sabe, em contextos diferentes a palavra muda facilmente de sentido. O significado, ao contrário, é um ponto imóvel e imutável que permanece estável em todas as mudanças de sentido das palavras em diferentes contextos (VYGOTSKY, 2009, p. 465).

Tal definição permite compreendermos que, ao falarmos de sentido, necessariamente estaremos falando de significado, já que este constitui aquele, sendo impossível, em termos metodológicos, separá-los. A definição nos aponta ainda o sentido como sendo construído na dinamicidade das relações sociais e nelas encarnado, constituído por zonas de estabilidade diferenciadas e necessariamente contextual.

A importância dos contextos, também denominados de cenários na RedSig, na construção das significações é um dos aspectos destacados nesta teoria. Bakhtin (2002) ressalta o caráter contextual do sentido e como o mesmo possui zonas de estabilidade e de instabilidade afirmando que

(...) o sentido de uma palavra é totalmente determinado por seu contexto. De fato, há tantas significações possíveis quantos contextos possíveis. No entanto, nem por isso a palavra deixa de ser una. Ela não se desagrega em tantas palavras quantos forem os contextos nos quais ela pode se inserir. Evidentemente, essa unicidade da palavra não é somente assegurada pela unicidade de sua composição fonética; há também uma unicidade inerente a todas as suas significações. Como conciliar a polissemia da palavra com sua unicidade? (...) Esse problema só pode ser resolvido pela dialética (BAKHTIN, 2002, p.106).

Bakhtin defende, no texto acima, a natureza contextual dos sentidos e concebe os processos de significação como sendo mutáveis e atrelados à realidade. Vygotsky, partindo do materialismo histórico-dialético inspirado em Marx, indica a importância dos contextos, das condições materiais de existência para a constituição de aspectos da consciência humana, como a produção de sentidos e significados. Para expressar e defender tal ideia, Vygotsky referencia a famosa frase de Marx: "não é a consciência que determina a vida, mas a vida que determina a consciência" (MARX; ENGELS, 1979, p.37). O autor, partindo desta premissa, 
afirma, assim como Bakhtin (2002), que a compreensão real de uma palavra tem que ser buscada na correlação viva desta com a realidade objetiva que ela significa (VYGOTSKY, 2009).

As considerações teóricas sobre a relação dos sentidos/significados e os contextos sociais permitem pensarmos como as significações dos participantes desta pesquisa profissionais da Educação Infantil e famílias - estão entrelaçadas com suas condições materiais de existência, com os contextos nos quais estão inseridos (assentamento rural, fazenda, campo, cidade e/ou Escola, dentre outros) e devem ser entendidas tendo em vista tais concretudes contextuais.

Ao discutirem os contextos sociais, as autoras da RedSig afirmam ainda que os mesmos são constituídos

(...) pelo ambiente físico e social, pela sua estrutura organizacional e econômica, sendo guiados por funções, regras, rotinas e horários específicos. Eles definem e são definidos pelo número e características das pessoas que o frequentam, sendo ainda marcados pela articulação da história geral e local, entrelaçadas pelos objetivos atuais, com os sistemas de valores, as concepções e crenças prevalentes. São também definidos por e definem os papéis sociais e as formas de coordenação de papéis/posicionamentos, contribuindo para a construção de relações profissionais, pessoais, afetivas e de poder entre os seus participantes (ROSSETTI-FERREIRA et al., 2004, p. 26).

Elementos materiais, pessoais e relacionais são indicados como constituidores dos cenários sociais. As autoras da RedSig ressaltam que, nessa perspectiva teórico-metodológica, os contextos são concebidos como indissociáveis das pessoas e entendidos a partir da concepção de meio defendida por Wallon (1986), e que teria a função de ambiente (contexto de aplicação de condutas) e a de condição, recurso e instrumento de desenvolvimento.

Aprofundando na discussão dos contextos sociais e dos processos de significação, Rossetti-Ferreira et al. afirmam que os mesmos seriam atravessados por uma matriz sóciohistórica, de natureza material e semiótica e composta por elementos de ordem social, cultural, política e econômica. De acordo com Rossetti-Ferreira et al. (2004), a matriz sóciohistórica é constituída por diferentes práticas, discursos e vozes, muitas vezes contraditórios, e que se constituem e se modificam dialeticamente ao longo da história.

A matriz sócio-histórica, os contextos e os processos de significação são constructos teóricos que estão imbricados na compreensão e constituição do que Rossetti-Ferreira et al. 
(2004) denominam de redes de significações. As redes de significações, para as autoras, seriam compostas

(...) por elementos de ordem pessoal, relacional e contextual, atravessados pela cultura, pela ideologia e pelas relações de poder, isto é, pelo que denominamos de matriz sócio-histórica, de natureza semiótica e polissêmica, a qual tem concretude e se atualiza continuamente no aqui e agora da situação, no nível dialógico das relações (ROSSETTI-FERREIRA et al., 2004, p. 17).

A partir da ocorrência de eventos e acontecimentos, ao longo do processo de desenvolvimento humano, há a rearticulação dos vários elementos das redes de significações e sua reconfiguração, levando à emergência de novos significados e à transformação das trajetórias das interações sociais.

A pessoa, dessa forma, encontra-se imersa em um mundo semiótico que delimita certas possibilidades de significação. Considerando os contextos nos quais está inserida e a matriz sócio-histórica que constitui tais contextos, diferentes redes de significações são disponibilizadas, circunscrevendo possibilidades de interações sociais e de novas significações.

Partir da ideia de que as interações humanas e os processos de significação são atravessados e circunscritos por elementos pessoais, contextuais e da matriz sócio-histórica que estão intrinsecamente relacionados, lança ao pesquisador desafios metodológicos no estudo das interações, significações e desenvolvimento humano.

Segundo Rossetti-Ferreira et al. (2008), considerando os pressupostos da RedSig, caberá ao investigador a tarefa de não simplificar os fenômenos nas suas partes constituintes, ou seja, não reduzir o fenômeno complexo a seus componentes elementares. Para tanto, as autoras ressaltam que

(...) Há que se garantir que o olhar do pesquisador ao micro, ao objeto focalizado, também compreenda a possibilidade de um movimento que o articule aos elementos de outra ordem, às mediações históricas e culturais construídas ao longo das práticas sociais e dos processos desenvolvimentais (...) Trabalha-se com a possibilidade de uma dialética que contemple tanto um esforço mais descritivo dos vários elementos que compõem a situação investigada (buscando-se inclusive compreender as relações de coordenação e subordinação desses elementos), como um empreendimento de busca dos processos de constituição do fenômeno (ROSSETTI-FERREIRA et al., 2008, p.153).

Caberá, então, ao pesquisador compreender os diversos elementos - como os da matriz sócio-histórica e dos contextos sociais - que constituem seu objeto de pesquisa, sejam eles de 
natureza discursiva ou material, bem como suas inter-relações. Tal procedimento não indica, porém, a busca pela completude, o que consideramos impossível, mas sim a consideração e compreensão da complexidade inerente aos fenômenos (MORIN, 1990) e uma tentativa de compreensão das suas totalidades.

Tais pressupostos teóricos fundamentaram o desenvolvimento deste estudo e, também, a forma de apresentação da escrita do trabalho. Nos próximos capítulos, buscamos evidenciar elementos da matriz sócio-histórica e que nos remetem à questão da relação entre a Educação Infantil e as famílias do campo; apresentamos elementos dos contextos nos quais a pesquisa foi realizada e as significações dos participantes da pesquisa sobre a temática abordada. Realizamos a discussão escrita dos mesmos separadamente, conforme indicado na Apresentação da pesquisa, para facilitar o entendimento do estudo. No entanto, consideramos os elementos da matriz sócio-histórica e dos contextos como imbricados nos processos de significação dos participantes da pesquisa. 



\section{CAPítulo}

2

ELEMENTOS DA MATRIZ SÓCIO-HISTÓRICA E A CONSTRUÇÃO DO OBJETO DA PESQUISA

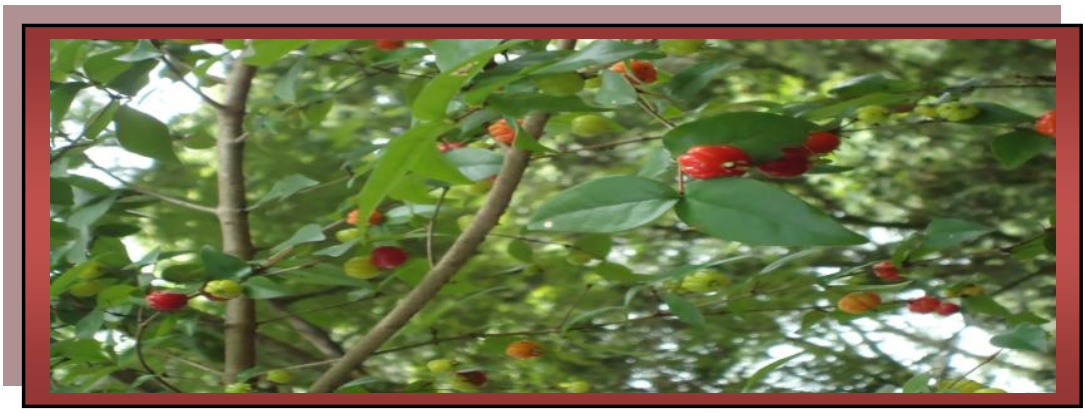





\title{
2. ELEMENTOS DA MATRIZ SÓCIO-HISTÓRICA E A CONSTRUÇÃO DO OBJETO DA PESQUISA
}

\begin{abstract}
"As ideias não surgem do vácuo, mas estão inseridas e são estimuladas e influenciadas pelo momento histórico em que surgem" (Rossetti-Ferreira, 1984).
\end{abstract}

No presente capítulo, buscamos apresentar e discutir elementos da matriz sóciohistórica que atravessam e a partir dos quais emerge o objeto de estudo desta pesquisa: a relação entre a Educação Infantil e as famílias do campo. Para tanto, apresentamos a seguir os seguintes subcapítulos: 2.1. A Educação Infantil no Brasil: elementos históricos da complementaridade do cuidado e educação da criança entre Creches/Pré-escolas e famílias; 2.2. A relação entre a Educação Infantil e as famílias; 2.3. A relação entre a Educação Infantil e as famílias do campo e os objetivos da pesquisa.

\subsection{A Educação Infantil no Brasil: elementos históricos da complementaridade do cuidado e educação da criança entre Creches/Pré-escolas e famílias}

\begin{abstract}
"... Nós não cuidamos, nós cuidamos e educamos. Porque agora as instituições trabalham dessa forma, não é assistencialista. É com... essa forma de... como que fala? De, de educar, cuidar, fazer as duas coisas ao mesmo tempo (...) Mas, as mães, as visões delas é só do cuidar mesmo. Que elas acreditam que estando aqui, é... está bem alimentada, as crianças...". (Gestora de uma instituição de Educação Infantil no campo)
\end{abstract}

O relato acima foi construído por uma gestora de uma instituição de Educação Infantil localizada no campo do município no qual a presente pesquisa foi realizada. A gestora, em sua fala, evidencia a existência de mudanças nos objetivos das instituições de Educação Infantil, afirmando que "agora", neste período histórico, Creches e Pré-escolas teriam a função de cuidar e educar as crianças. A gestora indica como, em sua concepção, as famílias defenderiam objetivos diferenciados da Educação Infantil, da relação destas instituições com suas crianças. Tal fala nos incita a considerar, compreender e discutir a Educação Infantil e sua relação com as crianças/famílias na sua historicidade.

No nosso país, até meados do século XIX, o cuidado e educação da criança eram realizados fundamentalmente nas residências familiares, localizadas, em sua maioria, no âmbito rural. Neste contexto, eram inexistentes as instituições de Educação Infantil. Segundo Oliveira (2002), predominava, nesse período, a concepção de que o ambiente doméstico seria 
o mais adequado para a criação das crianças pequenas, cabendo à mulher o papel de cuidar e educar seus filhos. Foi a partir da segunda metade do século XIX que começamos a assistir, na realidade brasileira, o surgimento das primeiras instituições que se dedicavam a receber as crianças. Podemos afirmar que a origem de tais instituições esteve entrelaçada com o desenvolvimento das grandes cidades, devido ao êxodo rural, e que trouxe novas condições de existência para a infância brasileira. Oliveira (2002) pontua que a abolição da escravatura e a grande migração da população do campo para a cidade originaram demandas e dificuldades nas cidades em relação à infância. A existência de crianças libertas, filhos de pais escravos, resultou no aparecimento, nos centros urbanos, de uma população de crianças abandonadas. Tal população era ainda composta, segundo Paschoal e Machado (2009), por crianças que eram abandonadas por motivos como o fato de a mãe ser solteira, o que era moralmente condenado pela sociedade. As autoras enfatizam ainda que a infância, nos grandes centros urbanos, também era ameaçada por altas taxas de mortalidade, devido às precárias condições de vida oferecidas nestes locais.

De acordo com Paschoal e Machado (2009), a fim de resolver a questão do abandono e mortalidade das crianças nas cidades, foram criados, nos centros urbanos, Asilos, Internatos e Creches, que eram igualados na sua função social: proteger e cuidar das crianças pobres e abandonadas. Conforme indicam diversos autores (CRAIDY; KAERCHER, 2001; OLIVEIRA, 2002; SOUZA; KRAMER, 1988; PASCHOAL; MACHADO, 2009), essas primeiras instituições que recebiam as crianças realizavam um trabalho de cunho assistencialista e eram vistas como uma solução possível, mas não adequada para cuidar da infância. A visão de que a família deveria ser a única responsável por seus filhos ainda predominava. A construção das Creches justificava-se, no imaginário social da época, como uma forma de suprir falhas dos pais no que tange ao cuidado e à educação das crianças.

Além da criação dos Internatos, Asilos e Creches, na segunda metade do século XIX constatamos ainda o surgimento dos jardins de infância. Tais instituições baseavam-se nas propostas do movimento da Escola Nova e eram voltadas para o atendimento da população privilegiada economicamente. Os jardins de infância possuíam, ao contrário das instituições que atendiam as crianças das camadas populares, uma proposta pedagógica pautada nas ideias de Froebel, pedagogo e fundador do jardim de infância na Alemanha em 1840 (OLIVEIRA, 2002).

Ainda na segunda metade do século XIX, com a Proclamação da República, em 1889, mudanças sociais acentuaram a demanda por instituições de Educação Infantil. Após esse período, houve um acelerado crescimento das indústrias e das cidades, havendo um forte 
êxodo rural. Nas grandes cidades, houve a entrada da mulher no mercado de trabalho e sua inserção na classe operária.

A alteração na dinâmica familiar, com a ida da mulher para o mercado de trabalho, gerou demandas para o atendimento da criança. No entanto, diante da ausência da atuação das indústrias e do Estado para a solução desta problemática, coube às famílias a busca de soluções particulares para esta questão, sendo que muitas vezes deixavam seus filhos com parentes, vizinhos ou outras pessoas da comunidade. Tais condições de vida e de trabalho das famílias operárias contribuíram para que a questão do atendimento da criança em instituições educativas fosse uma das frentes de luta do movimento operário, que eclodiu no século $\mathrm{XX}$ (OLIVEIRA, 2002).

Nesse século, discursos médicos também se somaram às vozes que falavam a favor da estruturação de melhores formas e condições de atendimento para as crianças pobres que eram afetadas, na visão higienista, pelo surgimento de novas configurações familiares devido à saída da mulher de suas residências para a inserção no mercado de trabalho. Vasconcelos e Sampaio $(1938)^{2}$, que eram cientistas e pediatras da época no Estado do Rio de Janeiro, teceram críticas ao trabalho extradoméstico das mulheres das camadas populares, afirmando que tal prática contribuía para lançar as crianças a uma situação de abandono e de falta de cuidados. Tais autores, ao se referirem à situação das famílias da sua época, pautavam-se em um modelo de família nuclear burguesa, vistas como superiores às demais, conforme indica o relato abaixo:

(...) As classes mais abastadas têm uma relativa facilidade para conseguir viver em harmonia no lar, não só por que a situação econômica é mais favorecida como também porque há mais probabilidade de marido e mulher serem dotados de mediana educação, quando não é boa, além de moral hereditariamente sadia. No nosso meio a forma mais perfeita de lar é aquela em que o marido trabalha para a manutenção e a mulher cuida da higiene e educação dos filhos (...) Ora, nas classes pobres essa forma de lar é materialmente irrealizável. Para cooperar no sustento da casa a mulher é sempre forçada a trabalhar (VASCONCELOS; SAMPAIO, 1938, p.15).

As famílias de camadas populares eram consideradas como sendo "desestruturadas" e suas práticas ameaçadoras para a saúde e a educação corporal e moral das crianças. Neste cenário, a abertura de instituições de Educação Infantil para assistir as crianças enquanto as

\footnotetext{
${ }^{2}$ Esta referência, assim como outras utilizadas neste trabalho (ver item Referências), foi obtida por meio de consulta à página virtual História da Educação e da Infância - Portal Fundação Carlos Chagas (http://www.fcc.org.br/pesquisa/jsp/educacaoInfancia/index.jsp), que tem como objetivo divulgar documentos históricos (textos e imagens) e resultados de pesquisas sobre a infância e sua educação.
} 
mães trabalhavam, bem como para intervir nas práticas familiares junto à infância, era justificada por discursos médicos. Para estes autores, a existência de tais instituições era essencial como forma de combater a mortalidade infantil que assolava a população dessa época. Dados desse período indicam que a mortalidade de crianças em cidades brasileiras crescia de $20 \%$ a $30 \%$ ou até mais em algumas cidades (VASCONCELOS; SAMPAIO, 1938).

Na opinião de Vasconcelos e Sampaio (1938), um dos fatores que também contribuía para manter a alta taxa de mortalidade das crianças nas cidades, e que também estava associada à "desestruturação" familiar, era a persistência do comércio das criadeiras, já existente no século anterior. A criadeira, também chamada de tomadeira de conta, foi assim definida por estes médicos:

(...) Uma tomadeira de conta ou criadeira não é uma mulher qualquer. Sobralhe esperteza e ascendência moral sobre aquelas que lhe confiam os filhos. Tem seu preço fixo e não transige. O Dr. Massilon Saboia, num dos muitos trabalhos que tem feito em defesa da criança, com palavra autorizada diz: 'São geralmente velhas vizinhas das empregadas ou moradoras das mesmas estalagens que durante o dia, mediante retribuição, cuidam dos filhos das que vão trabalhar. Algumas são ignorantes e más, outras portadoras talvez de doenças contagiosas, que só por interesse e necessidade sujeitam-se a tal mister; outras, finalmente, serão boas e carinhosas' (VASCONCELOS; SAMPAIO, 1938, p. 83).

(...) A criaderia é uma mulher ignorante dos mais comezinhos preceitos de higiene. Essa ignorância é lhe apanágio próprio. Pouco se incomoda que o lactente tenha ou não apetite, durma regular ou irregularmente. Descuida da alimentação e do trato das crianças (...) A ânsia no lucro faz com que receba nos seus cômodos maior número de crianças do que eles podem comportar (VASCONCELOS; SAMPAIO, 1938, p. 87).

Segundo os autores, as criadeiras cuidavam das crianças em ambientes insalubres e inadequados para a infância, conforme consta no relato abaixo:

(...) A residência da criadeira, por força da sua situação econômica, limita-se, via de regra, a um quarto aberto no corredor duma casa de cômodos, ou a um barracão levantado com folhas de zinco na raiz de um morro. $\mathrm{O}$ ar e a luz primam pela ausência em ambas essas moradas (...) É nesse ambiente que vamos encontrar, entregue às criadeiras, um punhado de crianças dispersas fora e dentro do barracão, oferecendo um espetáculo de desconforto e miséria. Os lactentes jazem, choramingando, em berços feitos de tábuas de caixotes, os narizinhos sempre sujos, donde escorre um catarro crônico, a pele desidratada, coberta de cascões, de eczemas e de furúnculos (...) Os maiorzinhos espalham-se pelo chão (...) roendo pedaços de pão ou 
escarafunchando a terra com as mãos, mostrando desde já um ventre abaulado tenso de vermes (VASCONCELOS; SAMPAIO,1938, p. 84).

Para Vasconcelos e Sampaio (1938), as precárias condições dos ambientes onde as criadeiras assistiam as crianças, bem como suas práticas equivocadas junto à infância, eram responsáveis pelo surgimento de doenças infantis e que poderiam levar as crianças ao óbito. Por isso, as criadeiras foram conhecidas também por "fazedoras de anjos". Baseados em tais discursos sobre as criadeiras e sobre suas ações junto às crianças, os pediatras afirmaram veementemente que o comércio das criadeiras deveria ser combatido pelo Estado por meio da criação de Creches na zona urbana.

A abertura de Creches na zona rural, com caráter médico-sanitário, também foi defendida por Vasconcelos e Sampaio (1938) que apontavam para precárias condições de vida destas populações e que, na visão dos mesmos, contribuiriam para manter altos índices de mortalidade neste contexto, “... Não devemos esquecer o abandono em que vivem as pequenas cidades e as imensas zonas rurais de nosso país (...) Nas zonas rurais do Brasil a mortalidade infantil é de $50 \%$ (...) Esse fato demonstra exuberantemente a situação precária da vida nos campos, onde o homem vive na permanente expectativa do fatalismo das endemias" (VASCONCELOS; SAMPAIO, 1938, p. 206). Baseando-se em tais colocações os autores defendem a necessidade de haver, no campo, os Centros de Saúde Rural, composto por várias seções como a de assistência à maternidade e à infância, possuindo para tal finalidade maternidade e Creche.

Nesse contexto, Vasconcelos e Sampaio (1938) defenderam a abertura de Creches nas cidades e nos campos para proporcionar melhores condições de atendimento para a infância do século XX. No entanto, apesar da defesa destes autores pela abertura de Creches urbanas e rurais, a referência do surgimento e da expansão destas instituições está vinculada fundamentalmente às cidades.

No que tange à expansão das Creches nas cidades, de acordo com documentos da época, a mesma ocorreu ancorada na concepção de que eram um "mal necessário". Em uma Revista do Serviço Social, publicada em 1944, notamos como a abertura de Creches era vista e justificada nessa época:

(...) Considerando a situação moral e econômica da família, principalmente tratando-se das classes mais pobres, reconhecemos a necessidade da existência das Creches. São elas um mal necessário. Dizemos um mal porque são o sintoma de um desajustamento moral ou econômico; porque nos falam de uma sociedade mal organizada, onde a mulher precisa abandonar a 
formação e educação dos filhos, para ajudar o marido a sustentar o lar; falam-nos do desamparo em que se encontram as famílias numerosas (...) Dizemos que são um mal necessário porque a sua existência acarretaria males maiores, como por exemplo a dissolução da família, a delinquência infantil, um sem número de crianças débeis físicas e quem sabe mentais. A Creche, pois, é necessária. É necessária como auxiliar da família, que por um motivo moral ou econômico esteja desorganizada (MANCINI, 1944, p.84).

De acordo com Mancini (1944), a Creche deveria atender famílias de camadas populares "desorganizadas". Tal atendimento deveria ser transitório, sendo desejável que a criança voltasse ao lar quando a família se reestruturasse, cabendo à Creche auxiliá-las para superar suas dificuldades. Ao defender as Creches como auxiliares das famílias, a autora afirma:

(...) Não adianta, pois para ajudar a família contentar-se a Creche em ficar com a criança pelo tempo e horário conveniente às mães. Ela deve ajudar a família nas suas outras necessidades, promovendo o quanto possível a união familiar. Não se há de supor que a única necessidade em uma família seja colocar o filho em uma Creche. Poderá esta, em algum tempo, ser a maior, nem sempre a única (MANCINI, 1944, p.102).

O auxílio às famílias, nessa conjuntura, tinha como meta a adequação das famílias populares a um modelo de família nuclear burguesa e deveria ocorrer com base nos preceitos médicos e higienistas, difundidos no Brasil desde o final do século XIX. Segundo Martins (2008), no século XX, há a consolidação, na realidade brasileira, da autoridade do especialista em crianças com a emergência da pediatria e da puericultura, ocorrendo a popularização do saber médico no que tange ao cuidado da criança. Ao mesmo tempo, segundo a autora, foi difundida a desconfiança em relação aos conhecimentos e práticas maternas, defendidos e compartilhados pelas mães, sogras, parentes, vizinhas, consideradas inadequadas e perigosas para a saúde e bem-estar da criança. A mãe, colocada nesse cenário como principal cuidadora da criança, deveria seguir os preceitos médicos e não os populares, para evitar males comuns na época como a mortalidade infantil.

(...) Consideradas as responsáveis diretas pelo bem e pelo mal das crianças, as mulheres sofreram um processo de culpabilização pelas doenças e morte dos filhos, pois segundo os médicos, algumas eram teimosas, ignorantes e apegadas às práticas da medicina popular, fonte de abusos e de erros, segundo a interpretação da medicina clínica. Cabia aos médicos, apoiados pelo Estado e pela iniciativa privada, orientar as mães, conduzi-las pelo reto caminho da puericultura, disciplinando-as e fiscalizando-as (MARTINS, 2008, p.140). 
As Creches, nesse contexto, eram vistas e reconhecidas em documentos legais da época como importantes instituições do Estado para a divulgação e implementação dos preceitos médicos sobre o cuidado da criança de camadas populares. Nesse período, as Creches eram defendidas como elementos da puericultura social e que poderiam cumprir uma importante meta: combater o comércio da criadeira (VIEIRA, 1988). Tal papel social atribuído às Creches contribuiu para o crescimento dessas instituições nos centros urbanos.

Oliveira (2002) pontua ainda que, nessa época, além da expansão das Creches, surgiram classes pré-primárias junto às instituições escolares em diversas cidades do Brasil, havendo, dessa forma, o atendimento da criança em diferentes contextos tais como Parques infantis, Escolas maternais, Jardins de infância, Creches e Classes pré-primárias. Para a autora, a origem das Creches e Pré-escolas, nesse período, vinculou-se às concepções assistenciais, possuindo, entretanto, outros objetivos como a prevenção da marginalidade e criminalidade das crianças, pobres e filhos de operários, bem como a intervenção direta nas práticas familiares.

Durante a segunda metade do século XX, com a maior industrialização e urbanização, houve o crescimento do contingente de mulheres que trabalhavam fora do âmbito doméstico e aumento da demanda por atendimento das crianças em instituições de Educação Infantil. Segundo Oliveira (2002), as Creches que atendiam crianças em período integral passaram a ser mais procuradas, tanto por operárias e empregadas domésticas, como por outras profissionais como as trabalhadoras do comércio e funcionárias públicas.

Devido às mudanças sociais e pressões das comunidades pela Educação Infantil, avanços na legislação começaram a ocorrer. Com a promulgação da Lei de Diretrizes e Bases da Educação em 1961, a educação pré-escolar foi definida como aquela que se destina às crianças menores de 7 anos, devendo ser ministrada em Maternais ou Jardins de infância. Nesta legislação, afirmava-se que as empresas seriam estimuladas a manter, por iniciativa própria ou em parceria com o poder público, instituições de educação pré-primária para atender os filhos das funcionárias (OLIVEIRA, 2002).

No entanto, com o Golpe Militar em 1964, houve mudanças no movimento em prol da Educação Infantil. De acordo com Oliveira (2002), no período dos governos militares, as políticas adotadas em nível federal continuavam a propor que Creches e mesmo Pré-escolas fossem equipamentos sociais de assistência à infância pobre. Segundo Kuhlmann Jr. (2000), tais governos incorporaram diretrizes de organizações internacionais, como do Fundo das Nações Unidas para a Infância (UNICEF) que incentivava a criação de instituições para atendimento à criança, baseando-se em um modelo de baixo custo. 
Figueiras (1994) afirma que até os anos de 1970 as ações do Estado brasileiro no que tange às Creches atingiam de forma precária uma pequena parcela da população de crianças. Tais ações consistiam, em sua maioria, no oferecimento de subvenções às Creches fundadas pela população em localidades carentes dos centros urbanos com o intuito de compensar supostas carências sociais destas populações. No mesmo sentido, Nunes (2009) afirma que

(...) os espaços físicos inadequados, a falta de recursos e materiais pedagógicos, o pessoal mal remunerado e a parceria entre o público e o privado sem fins lucrativos formaram a rede de atendimento que, durante muitos anos, dominou a educação voltada para as crianças pequenas e pobres na faixa de zero a seis anos. Esta rede foi iniciada ainda nos anos 1930, sob a égide das Creches empresariais e/ou assistenciais e filantrópicas, e ampliouse entre os anos 1950 e 70, sob a influência da Legião Brasileira de Assistência (LBA) numa perspectiva de ampliação da rede em parceria com entidades comunitárias (NUNES, 2009, p. 87).

Para Kuhlmann Jr. (2000), no entanto, tais políticas que visavam à solução dos problemas sociais não foram suficientes para conter os conflitos no país. Oliveira (2002) afirma que, nessa época, diante das precárias condições de vida da população nas cidades e da falta de políticas sociais eficientes, houve a mobilização de vários segmentos sociais reivindicando os direitos dos trabalhadores e de suas famílias e, dentre eles, o atendimento da criança na Educação Infantil.

(...) Nesse período, o crescimento do operariado, o começo da organização dos trabalhadores do campo para reivindicar melhores condições de trabalho, a incorporação crescente também de mulheres no mercado de trabalho, a redução dos espaços urbanos propícios às brincadeiras infantis, como quintais e ruas, fruto da especulação imobiliária e do agravamento do trânsito, e a preocupação com a segurança contribuíram para que a Creche e Pré-escola fossem novamente defendidas por diversos segmentos sociais (OLIVEIRA, 2002, p.108).

Para a autora, tais mobilizações contribuíram para o crescimento da Educação Infantil no país, porém desarticulado das propostas educacionais. Assistimos, nessa época, a um crescimento das instituições filantrópicas, assistenciais e comunitárias e das classes préescolares nas Escolas de Ensino Fundamental. Tal expansão ocorreu com a implementação dos programas em massa, voltados à população pobre, que funcionavam em condições estruturais precárias e que contavam com profissionais com baixo nível de escolaridade e sem formação específica (SILVA, 2008). Outra tendência da época foi o surgimento de 
instituições de Educação Infantil que, pautadas em uma visão tecnicista, buscavam realizar um trabalho de cunho escolar (OLIVEIRA, 2002).

Com a municipalização do atendimento, na década de 1970, a ideia das Creches e Préescolas como sendo instituições educativas, mesmo as voltadas para as classes menos favorecidas, passou a ser defendida também nesta esfera de atendimento (OLIVEIRA, 2002).

Segundo Souza e Kramer (1988), a coexistência de atendimentos não formais e formais de Educação Infantil e que ofereciam diferentes formas e condições de atendimento às crianças possibilitou que comunidades confrontassem propostas assistenciais e educacionais de atendimento à criança pequena, criando parâmetros de qualidade utilizados no processo de escolha e de demanda de serviços que iam ao encontro de suas necessidades e anseios.

Avanços científicos também contribuíram para a mudança nos olhares no que tange às instituições que recebiam as crianças. Nessa época, discursos médicos e psicológicos indicavam a relevância da qualidade nos contextos frequentados pelas crianças, afirmando a primeira infância como momento importante do desenvolvimento humano. Discursos científicos apontavam ainda que o desenvolvimento da criança iniciava-se com o seu nascimento, podendo ocorrer em contextos não familiares, como as Creches e Pré-escolas (OLIVEIRA, 2002).

Tais concepções construídas sobre a Educação Infantil contribuiriam para que, nas décadas de 1970 e 1980, houvesse a demanda da população por Creches e Pré-escolas com qualidade. Essas décadas foram marcadas por uma grande mobilização nacional, incitada pelos movimentos sociais - como o sindical, o feminista e o estudantil - em prol da democratização do país e da educação, que contribuíram para a derrocada do regime militar.

De acordo com Kuhlmann Jr. (2000), a reivindicação pela Educação Infantil nesse período estava articulada também a objetivos sociais mais amplos:

(...) As instituições de Educação Infantil tanto eram propostas como meio agregador da família para apaziguar os conflitos sociais, quanto eram vistas como meio de educação para uma sociedade igualitária, como instrumento para a libertação da mulher do jugo das obrigações domésticas, como superação dos limites da estrutura familiar. As ideias socialistas e feministas, nesse caso, redirecionavam a questão do atendimento à pobreza para se pensar a educação da criança em equipamentos coletivos, como uma forma de se garantir às mães o direito ao trabalho. A luta pela Pré-escola pública, democrática e gratuita se confundia pela luta com as transformações sociais mais amplas (KUHLMANN JR, 2000, p.11). 
Rosemberg (2001) afirma que a Educação Infantil, nessa época, é entrelaçada à questão dos direitos da criança e, concomitantemente, aos direitos de igualdade de oportunidades entre homens e mulheres.

Podemos considerar que as reivindicações dos movimentos sociais por uma Educação Infantil pública, gratuita e de qualidade foram contempladas juridicamente após o fim da ditadura, com a aprovação, em 1988, da Constituição Federal. Tal legislação afirma a Educação Infantil como direito de todas as crianças, opção das famílias e dever do Estado. A Educação Infantil é indicada ainda nesta legislação como direito social de trabalhadores rurais e urbanos. Os artigos que versam sobre esta temática na Constituição de 1988 são apresentados a seguir:

Art. $7^{\circ}$. São direitos dos trabalhadores urbanos e rurais, além de outros que visem à melhoria de sua condição social:

(...) XXV - assistência gratuita aos filhos e dependentes desde o nascimento até 5 (cinco) anos de idade em Creches e Pré-escolas (BRASIL, 1988).

Art. 208. O dever do Estado com a educação será efetivado mediante a garantia de:

(...) IV - educação infantil, em Creche e Pré-escola, às crianças até 5 (cinco) anos de idade (BRASIL, 1988).

Ainda na década de 1990, houve a aprovação, no país, do Estatuto da criança e do adolescente (ECA), em 1990, e da Lei de Diretrizes e Bases da Educação (LDB), em 1996, que reafirmam a Educação Infantil como direito da criança e opção da família. A LDB indica ainda que a Educação Infantil tem como objetivo complementar a família no cuidado e educação da criança, promovendo seu desenvolvimento integral, inserindo-a no sistema de ensino como primeira etapa da educação básica.

Para Haddad (2002) e Fortkamp (2008), os dispositivos legais citados acima inovaram ao indicar a função da Educação Infantil de complementar e compartilhar com a família a tarefa de cuidar e educar a criança, o que significa a necessidade de participação do Estado no processo educativo das crianças de 0 a 5 anos, anteriormente atribuída exclusivamente às famílias. Resguardando-se as especificidades e papéis diferenciados da família e da Educação Infantil enquanto instituições socializadoras da infância, ambas foram responsabilizadas pela educação e pelo desenvolvimento global da criança.

Outros importantes documentos legais elaborados no país e referentes à Educação Infantil foram as Diretrizes Curriculares Nacionais para a Educação Infantil (BRASIL, 1998, 2009b). A revisão das Diretrizes Curriculares Nacionais para a Educação Infantil, aprovada 
em 2009, também indica o dever do poder público no oferecimento da Educação Infantil por meio da expansão da rede pública de atendimento (BRASIL, 2009b). Tendo em vista a trajetória histórica do surgimento das instituições de Educação Infantil no Brasil - por meio da parceria com instituições criadas pela população, principalmente no que tange às crianças de 0 a 3 anos - a LDB permite o atendimento da Educação Infantil oferecido em instituições privadas sem fins lucrativos, comunitárias, filantrópicas e confessionais, por meio de convênio com as Prefeituras municipais (BRASIL, 1996). O Ministério da Educação indica, porém, que as mesmas devem estar de acordo com as orientações nacionais sobre a política de conveniamento para a oferta de Educação Infantil, normatizadas por este órgão da administração federal (BRASIL, 2009d). Vale destacar que, atualmente, a regulamentação nacional entende que a Educação Infantil é um tipo de atendimento oferecido à criança em Creches e Pré-escolas, sendo as mesmas espaços institucionais não domésticos, públicos ou privados, que educam e cuidam de crianças de 0 a 5 anos de idade no período diurno, em jornada integral ou parcial, regulados e supervisionados por órgão competente do sistema de ensino e submetidos a controle social (BRASIL, 2009b).

Legislações do país (BRASIL, 1996, 2009b) e publicações realizadas pelo Ministério da Educação, tais como os Padrões de Infra-estrutura para instituições de Educação Infantil e Parâmetros de qualidade para a Educação Infantil (BRASIL, 2004) e os Indicadores da qualidade na Educação Infantil (BRASIL, 2009c), determinam ainda critérios de qualidade a serem seguidos pelas instituições de Educação Infantil. Tais documentos indicam parâmetros a serem contemplados pelas instituições no que tange à sua estrutura física, formação dos profissionais, proporção adulto e criança, alimentação, relação com a família, tendo em vista a promoção de um atendimento com qualidade das crianças, famílias e comunidades em instituições de Educação Infantil.

As legislações e publicações citadas acima (BRASIL, 1988, 1990, 1996, 2004, 2009b, 2009c, 2009d) são de abrangência nacional. Dessa forma, as mesmas são direcionadas para todas as instituições brasileiras de Educação Infantil, seja ela pública ou privada, da cidade ou do campo. No que tange às instituições de Educação Infantil localizadas no âmbito rural, é importante mencionarmos que outras legislações e documentos nacionais referentes à Educação Básica no campo foram publicados, regulamentando também a questão da Educação Infantil no campo juntamente com as outras modalidades de ensino que compõem a Educação Básica. Dentre estes documentos, destacam-se as Diretrizes Operacionais para a Educação Básica nas Escolas do Campo (BRASIL, 2002) e as Diretrizes Complementares, Normas e Princípios para o Desenvolvimento de Políticas Públicas de Atendimento da 
Educação Básica do Campo (BRASIL, 2008). Estes reafirmam a Educação Infantil no campo como direito das crianças e das famílias, indicando o dever do Estado em oferecer o atendimento das crianças do campo em Creches e Pré-escolas localizadas na zona rural e que atendam com qualidade à população, respeitando-se as diversidades culturais e sociais das comunidades.

Outra importante conquista legal referente às instituições de Educação Infantil no campo foram as Diretrizes Curriculares Nacionais para a Educação Infantil, promulgadas em 2009, e citadas anteriormente. Tal documento representa avanços conquistados pelos movimentos sociais ligados à Educação Infantil e à Educação do Campo, já que vem defendendo uma proposta de educação que valoriza o protagonismo dos povos do campo no processo de construção do conhecimento, bem como as suas especificidades culturais no planejamento e realização das práticas institucionais e na construção do projeto político e pedagógico das Escolas no campo (BRASIL, 2009b). A nosso ver, a indicação e valorização das especificidades dos povos do campo na construção das propostas pedagógicas de Creches e Pré-escolas rurais, realizadas neste documento, contribuem para colocar em evidência, no âmbito legal e social, a questão da Educação Infantil no campo.

O processo de reconhecimento da Educação Infantil no campo, no contexto social, foi ainda impulsionado após a aprovação das Diretrizes Curriculares Nacionais para a Educação Infantil (BRASIL, 2009b), pelas discussões surgidas no processo de elaboração das Orientações Curriculares Nacionais para a Educação Infantil. Para orientar os municípios na aplicação das Diretrizes Curriculares Nacionais para a Educação Infantil, o Ministério da Educação solicitou a diversos pesquisadores nacionais a elaboração de vários textos temáticos, sendo um deles específico sobre Orientações Curriculares Nacionais para a Educação Infantil do Campo (SILVA; PASUCH, 2010). Tal documento foi feito a partir de discussões realizadas em reuniões técnicas promovidas nas diferentes regiões do país, com a participação do poder público, universidades e movimentos sociais, e aborda pontos importantes referentes à Educação Infantil no campo, como a questão das práticas pedagógicas; organização dos tempos, espaços e atividades; formulação do projeto políticopedagógico; relação com a família e comunidade.

Evidenciamos, dessa forma, no século XXI, avanços legais referentes à Educação Infantil e à Educação Infantil no campo. No que tange à Educação Infantil no campo percebemos que a mesma se desenvolveu, no âmbito jurídico, atrelada à Educação Infantil e à Educação do campo. Nestas duas áreas, a Educação Infantil vem sendo defendida como 
direito das crianças e famílias moradoras em territórios rurais, cabendo às Creches e Préescolas complementarem o cuidado e educação das crianças com as famílias do campo.

O presente trabalho, conforme já mencionado anteriormente, propõe discutir especificamente a questão da relação entre a Educação Infantil no campo e as famílias do campo. Ao apresentarmos, neste item, elementos históricos da complementaridade do cuidado e educação da criança entre a Educação Infantil e famílias, da cidade e do campo, consideramos que demos início a tal debate. A fim de aprofundar a discussão da relação entre a Educação Infantil e famílias trazemos, no próximo item, dados mais gerais sobre a temática, a partir da discussão de documentos nacionais que a norteiam, bem como de pesquisas da área. Posteriormente, propomos aprofundar na questão da relação entre a Educação Infantil e famílias no âmbito rural.

\subsection{A relação entre a Educação Infantil e as famílias}

“... Eles falam assim que a Escola e os pais têm que ser juntos, né? Então assim, a Escola ajuda também a gente, né? Com tudo, né? Questão de educação (da criança), com tudo...". (Família do campo)

No primeiro item deste capítulo, discutimos como o surgimento da Educação Infantil (urbana) esteve atrelado a uma ideia de que suas instituições teriam como meta assistir as crianças e, concomitantemente, intervir na educação ofertada pelas famílias de camadas populares para a melhoria das suas práticas no que tange ao cuidado e à educação da criança. De acordo com Kuhlmann Jr. (2000), na sua origem, as Creches foram concebidas como um meio de educar as famílias das camadas populares, "para os pobres as Creches seriam um meio para promover a organização familiar, e por isso sempre se colocou como complementar a ela”. O autor destaca que, até o início da década de 1980, as Creches tinham o intuito de interferir na vida familiar, "extrapolando o necessário intercâmbio entre família e instituição" (KUHLMANN JR., 2000, p.12).

No final da década de 1980 e na década de 1990, porém, com a promulgação do Estatuto da Criança e do Adolescente (1990) e da Lei de Diretrizes e Bases da Educação (1996), assistimos, na realidade brasileira, ao surgimento de discursos legais diferenciados referentes à Educação Infantil e à relação entre Creches/Pré-escolas e famílias.

A fala citada acima, de uma das famílias participantes desta pesquisa, se alia às concepções jurídicas defendidas na atualidade sobre a necessidade da Educação Infantil e famílias atuarem conjuntamente no processo de cuidado e educação da criança, a partir do 
estabelecimento de uma relação de proximidade. No Estatuto da Criança e do Adolescente afirma-se que é direito dos pais ou responsáveis ter ciência do processo pedagógico, bem como participar da definição das propostas educacionais das instituições escolares (BRASIL, 1990). No mesmo sentido, na LDB indica-se que as instituições de educação deverão realizar um trabalho articulado com as famílias, tendo como um de seus princípios a gestão democrática da instituição. Neste documento, pontua-se ainda, no que tange às Creches e Préescolas, que tais instituições devem complementar a ação da família, compartilhando com as mesmas o cuidado e a educação da criança (BRASIL, 1996), o que pressupõe a existência de uma relação mais próxima entre instituições familiares e Creches/Pré-escolas.

No Parecer do Conselho Nacional de Educação do Brasil no 20/2009 (BRASIL, 2009e), que versa sobre a revisão das Diretrizes Curriculares Nacionais para a Educação Infantil, e nas Diretrizes Curriculares Nacionais para a Educação Infantil (BRASIL, 2009b), afirma-se que Creches e Pré-escolas devem assumir a responsabilidade de complementar e compartilhar a educação e cuidado das crianças com as famílias, devendo garantir a participação, o diálogo e a escuta cotidiana destas na organização e desenvolvimento de sua proposta político-pedagógica, respeitando-se e valorizando-se suas diferentes formas de organização. Para garantir o estabelecimento de uma relação próxima entre as instituições de Educação Infantil e famílias, destaca-se a necessidade de criação, pelas Creches e Pré-escolas, de instrumentos que garantam a constante presença da família na instituição (BRASIL, 2009b).

Ressaltamos que a relação entre Educação Infantil e famílias é concebida atualmente como indicador de qualidade do serviço oferecido por Creches e Pré-escolas (BRASIL, 2009c). Em publicação do Ministério da Educação sobre os indicadores de qualidade da Educação Infantil, afirma-se que

(...) a instituição de educação infantil é um espaço de vivências, experiências, aprendizagens. Nela, as crianças se socializam, brincam e convivem com a diversidade humana. A convivência com essa diversidade é enriquecida quando os familiares acompanham as vivências e as produções das crianças. Estando aberta a essa participação, a instituição de educação infantil aumenta a possibilidade de fazer um bom trabalho, uma vez que permite a troca de conhecimento entre familiares e profissionais em relação a cada uma das crianças. Assim, família e instituição de educação infantil terão melhores elementos para apoiar as crianças nas suas vivências, saberão mais sobre suas potencialidades, seus gostos, suas dificuldades (BRASIL, 2009c, p. 57). 
O diálogo e a troca de conhecimentos entre famílias e profissionais da Educação Infantil, no texto citado, são mencionados como relevantes para o aprimoramento das instituições familiares, Creches e Pré-escolas no que tange ao processo de cuidar e educar a criança.

Percebemos, dessa forma, que atualmente a Educação Infantil é concebida, nos documentos legais, como instituição educativa que deve complementar as famílias na tarefa de cuidar e educar os filhos devendo, para tanto, ter como um dos eixos de seu trabalho o estabelecimento de uma relação democrática, de cooperação e de diálogo com as famílias.

Consideramos que tais avanços legais foram conquistas importantes na história da Educação Infantil, constituindo-se como instrumentos políticos na luta por sua qualidade e expansão no país. No que tange à expansão da Educação Infantil no Brasil, dados do Instituto Brasileiro de Geografia e Estatística - IBGE indicam que a taxa de frequência à Escola ou Creche de crianças de 0 a 6 anos de idade subiu, no período de 1991 a 2007, de 27,5\% para 44,5\% (IBGE, 2007). No entanto, apesar de tal expansão ainda verificamos, na realidade brasileira, o não oferecimento do atendimento na Educação Infantil para todas as crianças, principalmente para as de 0 a 3 anos. Há ainda no Brasil uma grande demanda das famílias por vagas na Educação Infantil. Segundo Rosemberg (2001), tal demanda de Educação Infantil é geralmente constatada por meio da lista de espera e não reflete a realidade, que pode ser ainda mais drástica. A autora, em diálogo com Bloch e Buisson (1998), define demanda como sendo:

(...) uma necessidade sentida e expressa. Ela pode ser explícita ou latente: a explícita é avaliada através da procura de um serviço. A demanda latente é aquela que não se expressa espontaneamente, por alguma razão (distância entre domicílio e equipamento, qualidade ou tipo de serviço oferecido, etc.) (...) Confunde-se, frequentemente, necessidade com demanda: considera-se que, desde que sejam pobres, todas as famílias de crianças pequenas têm demanda por serviços, olvidando-se da mediação de valores para que uma necessidade se configure em demanda (ROSEMBERG, 2001).

A autora afirma ainda que, no nosso país, são escassos os estudos para identificar a demanda latente, o que traduz um desconhecimento sobre a dimensão desta, bem como sobre quais modalidades de serviços são preferidos pela população. Nesse cenário, são levantados dados apenas através do que denominamos de "lista de espera", por meio da demanda "explícita".

Além da existência de uma grande demanda "explícita" por Educação Infantil no Brasil, o que fragiliza a relação de complementaridade entre poder público e famílias no 
cuidado e educação da criança, diversos estudos têm indicado ainda dificuldades na relação entre pais e Creches/Pré-escolas. Ao analisarmos pesquisas realizadas desde o período de 1987 até a atualidade (no contexto urbano), percebemos que, de uma forma geral, as mesmas vêm apontando a relação entre a Educação Infantil e famílias como sendo distante e/ou permeada por problemáticas que prejudicam a realização de um trabalho integrado e dialógico entre pais e profissionais da educação, tendo em vista o desenvolvimento integral da criança (HADDAD, 1987; VITORIA, 1997, 1999; BHERING; NEZ, 2002; MEIRA, 2004; CORREA, 2006; FORTKAMP, 2008). Em tais estudos, foram ausentes ou raros os aspectos identificados e que indicam a existência de uma relação de cooperação, de diálogo entre famílias e Creches/Pré-escolas e que contribuem para a melhoria das práticas junto à criança nas famílias e na Educação Infantil. Em estudos que se propuseram a ter como participantes profissionais e famílias, outro elemento observado foi a existência de diferenças e confrontos de concepções de profissionais e famílias sobre a Educação Infantil e a relação desta com os pais.

Haddad (1987), a partir do desenvolvimento de uma pesquisa-ação sobre a relação família e Educação Infantil, realizada em uma Creche da Prefeitura do município de São Paulo e que atendia crianças de 0 a 3 anos de camadas populares, constatou em um primeiro momento da pesquisa - por meio de sua vivência enquanto diretora da instituição - que a relação entre as instituições familiares e de Educação Infantil era distante, sendo que as famílias desconheciam o que ocorria no interior da Creche, e os profissionais defendiam visões estereotipadas das famílias. De acordo com a autora, a Creche não reconhecia a família como legítima, assim como a família não reconhecia a Creche enquanto legítima. Havia na relação Escola e família a vigilância das mães sobre a Creche, devido à curiosidade de saber o que se passava no interior da Creche, e da Creche sobre as mães para julgar e controlar o comportamento das famílias. Existia por parte dos profissionais, nas palavras da pesquisadora, "um sentimento de que as mães não reconhecem e não valorizam o trabalho da Creche, de que as mães 'largam' seus filhos, não querem saber das dificuldades e dos problemas que os funcionários enfrentam" (HADDAD, 1987, p.72). Partindo desta realidade, houve a proposição e realização, em um segundo momento do estudo, de práticas para a "abertura" da instituição para as famílias. Nesta parte da pesquisa, constatou-se que a médio e longo prazo, tal "abertura" gerou incômodos nas profissionais diante da presença da família na Creche e da manifestação de agressões às mães. Por outro lado, as famílias manifestaram ciúmes da criança em relação às profissionais e sentimento de culpa por deixarem suas crianças na Creche, o que também contribuiu para tornar a relação conflituosa e tensa entre pais e 
profissionais. Segundo a pesquisadora, tais problemáticas envolvendo a Creche investigada se relacionavam com a existência, nas famílias e na Creche, da concepção da Educação Infantil como sendo substitutiva das funções maternas - e não de que tais instituições seriam complementares -, o que gerava rivalidades entre mães e profissionais da educação no que tange ao cuidado e à educação da criança. Cabe ressaltarmos que, no período de realização deste estudo, as Creches eram concebidas como instituições de guarda e proteção dos filhos das famílias de camadas populares e que prevalecia a ideia de que as mesmas tinham como objetivo substituir a família a partir de uma prática compensatória.

Após uma década de realização do estudo de Haddad (1987), na qual assistimos à aprovação de legislações que indicam o papel educacional da Educação Infantil em relação às crianças e complementar a família na tarefa de cuidar e educar seus filhos (BRASIL, 1988, 1990, 1996), Vitória (1997), ao investigar as representações sociais de educadoras sobre as famílias das crianças de uma Creche pública (Creche 1) e de uma Creche filantrópica (Creche 2) localizadas em municípios distintos de São Paulo e que atendiam, respectivamente, famílias de camadas médias e de camadas populares, encontrou alguns resultados semelhantes. Vitória (1997) constatou, em seu estudo, a existência de concepções equivocadas sobre o papel da Creche em relação à criança e à família. Na Creche 1 , houve a defesa da Creche como sendo potencialmente promotora de desenvolvimento, já, na Creche 2, ocorreu a defesa da Creche como sendo assistencial e substituta das funções maternais. Em ambas as instituições, verificou-se a existência de um posicionamento superior da Creche em relação às mães atendidas, o que, segundo a pesquisadora, pode desencadear conflitos entre profissionais e pais. Apesar de avaliarem a relação Creche e família como sendo relevante, devendo ser próxima para a troca de informações, as entrevistadas indicaram um distanciamento entre as instituições e defenderam concepções negativas das famílias atendidas, como sendo desinteressadas em relação aos filhos. A pesquisadora constatou ainda, no seu estudo, a defesa pelas profissionais de ambas as instituições de que a genitora seria a principal promotora do desenvolvimento infantil, sendo o ambiente familiar o ideal para educar a criança.

Assim como nas pesquisas de Haddad (1987) e Vitória (1997), notamos que estudos mais atuais sobre a relação entre a Educação Infantil e famílias também vêm indicando afastamentos entre as instituições, bem como a existência de conflitos e queixas nesta relação que não contribuiriam para melhorias das práticas conjuntas direcionadas às crianças. Bhering e Nez (2002), ao realizarem uma pesquisa com profissionais e famílias de uma Creche de iniciativa voluntária de Itajaí/Santa Catarina, constataram que as opiniões de pais e 
profissionais sobre as exigências, expectativas e responsabilidades de cada instituição (escolar e familiar) pareciam distanciar-se, havendo ainda a existência de falhas na comunicação entre pais e profissionais e que, segundo as pesquisadoras, impossibilitam a proximidade e dificultam o compartilhamento de informações sobre a criança. As pesquisadoras verificaram a existência de uma conduta dos pais de gratidão ao serviço prestado, de retraimento para dialogar com a Creche sobre a criança, e de passividade e conformidade frente ao serviço oferecido. Segundo Bhering e Nez (2002, p.68), para as famílias, a Creche continua sendo um local "seguro e de suprimento das necessidades básicas, havendo pouco interesse e envolvimento da parte dos pais em saber o que a Creche oferece à criança em termos pedagógicos e sociais, e oportunidades em geral". Já a Creche se coloca na posição daquela que oferece assistência às famílias e que confronta com os pais, vistos, pelas profissionais, como sendo aqueles que não respeitam regras da instituição (como horário de entrada e saída) e que omitem dados sobre a criança. De acordo com as pesquisadoras, pais e profissionais encontram-se cotidianamente na instituição, nos momentos de entrada e saída. No entanto, tais momentos são indicados como sendo curtos para a troca de informações sobre a criança. Outro momento de encontro seria em reuniões, porém estas não são consideradas como espaços de troca de informações sobre a criança, mas sim de comunicação pela Creche aos pais de problemas de comportamento da criança no âmbito institucional. As autoras indicam a relação Creche e família como sendo de confronto e distanciada.

Meira (2004), ao realizar uma pesquisa em um Centro de Educação Infantil de Foz do Iguaçu que atendia crianças de 3 a 6 anos pertencentes às camadas populares e que teve como participantes profissionais e mães de crianças que frequentavam a instituição, também verificou que a relação entre a instituição e as famílias era avaliada como sendo distante. A pesquisadora afirmou ainda que as participantes defenderam diferentes concepções relativas ao objetivo da Educação Infantil e à relação entre a Creche e famílias, sendo praticamente inexistente a comunicação entre as instituições. De acordo com a autora, os profissionais vislumbravam o oferecimento da Educação Infantil como sendo um favor, uma caridade prestada às famílias pobres que necessitam trabalhar no âmbito público, ora defendendo a concepção de Creche como sendo assistencial, ora como sendo substitutiva das práticas maternas de cuidado e educação da criança e ora como sendo educacional. As educadoras defenderam ainda concepções das famílias atendidas como sendo desinteressadas e inadequadas em relação ao cuidado e à educação da criança e não participativas na instituição, havendo a iniciativa de pais de conversarem com os profissionais somente para queixar-se do trabalho da Creche e para resolver situações de conflitos envolvendo a criança. Profissionais 
afirmaram que seria importante a participação da família no âmbito institucional, mas para prestar serviços (como reformar, limpar), auxiliar na organização de eventos, receberem reclamações sobre o comportamento da criança na Creche, ou quando a criança está doente. Já as famílias, na sua maioria, segundo Meira, veem a Creche como instituição assistencial, educacional e como ambiente que promove a socialização e proteção da criança e indicam que a permanência da criança na Creche ocorre pela falta de condições financeiras para contratarem uma babá, vista como sendo uma opção mais adequada para assistir as crianças. As famílias apontaram, ainda, a comunicação com as educadoras como sendo precária, não havendo a escuta da família e a discussão do cotidiano da criança na instituição, e mencionaram receios de expressar suas opiniões e críticas sobre a Creche no âmbito institucional. As mães afirmaram ainda que desejam participar das atividades da Creche, contribuindo com o cuidado e educação de seus filhos.

Sobre a participação familiar no âmbito da Educação Infantil, Côrrea (2006), ao observar práticas existentes ou potenciais de participação das famílias em uma Escola municipal de Educação Infantil localizada na cidade de São Paulo e que atendia crianças de 4 a 6 anos, verificou que a instituição buscava realizar um trabalho de qualidade com a participação das famílias, dispondo de meios institucionalizados para viabilizar tal participação com o Conselho da Escola, a Associação de Pais e Mestres, e a realização de reuniões periódicas para discussão do trabalho pedagógico. A pesquisadora verificou, porém, que nestes espaços, muitas vezes, as famílias não tinham poder, sendo subjugadas e persuadidas pelos profissionais nos momentos de decisão sobre aspectos do atendimento, não havendo de fato a existência de uma gestão democrática na instituição e do compartilhamento do cuidado e educação da criança entre Educação Infantil e famílias.

Dificuldades no compartilhamento do cuidado e educação da criança entre famílias e Educação Infantil também foram mencionadas em estudo realizado por Fortkamp (2008). O pesquisador, ao investigar se e como acontece a complementaridade na relação entre a Educação Infantil e família em uma instituição de uma cidade de Florianópolis, que atendia crianças de 1 a 6 anos provenientes de família de baixa renda, constatou que a complementaridade é pensada e desejada de uma forma equivocada pelos pais. Na perspectiva das famílias, a Educação Infantil é concebida como local de cuidado e educação da criança, havendo, porém, a exigência de que a instituição também acolha as mais variadas necessidades familiares e que não cabem à Creche/Pré-escola, como acesso aos serviços de saúde, o que gera, por vezes, conflitos entre pais e profissionais. Tais conflitos também ocorrem pelo não atendimento na Creche de todas as famílias que demandam vagas, 
indicando uma fragilidade na ação do poder público de garantir o direito da criança e da família a esta modalidade de educação, ou seja, de possibilitar o compartilhamento do cuidado e educação da criança entre as instituições de Educação Infantil e familiares.

Diferentemente das pesquisas acima mencionadas, que apontam dificuldades, tensões e problemas na relação entre a Educação Infantil e famílias, Saisi (2010) e Gallo (2010), ao investigarem tal temática, relataram a existência de uma interação mais positiva entre famílias e Educação Infantil nos contextos por elas estudados. Saisi (2010), ao realizar uma pesquisaação em uma instituição pública de Educação Infantil de São Paulo e que atendia crianças de 4 a 6 anos, verificou que famílias atendidas atribuíam um papel educacional à instituição e apreciavam o trabalho pedagógico dos profissionais junto às crianças. Pais indicaram ainda que as famílias consideravam que a Escola Municipal de Educação Infantil (EMEI) era aberta para receber as famílias e que mantinha um diálogo satisfatório com os pais, por meio de momentos como as reuniões e no Conselho Escolar. No entanto, de acordo com a pesquisadora, tal diálogo restringia-se ao recebimento de informações sobre a criança pela família, ficando evidente que, para os pais, a relação família e Escola centra-se na escola, que detém informações sobre a criança desconhecidas pelas famílias, devendo informá-las e orientá-las, visão esta compartilhada pelos educadores. A investigadora afirma que não havia um movimento da instituição de incorporar no seu projeto pedagógico informações advindas das famílias. Gallo (2010), ao pesquisar o que famílias, pertencentes a camadas populares e atendidas por três instituições de Educação Infantil de um município da região de Ribeirão Preto-SP, entendem por qualidade da instituição de Educação Infantil, constatou que a relação Escola e família era vista pelas famílias como um parâmetro de qualidade, sendo avaliada como tranquila e acolhedora, havendo a escuta pela instituição de críticas e questionamentos dos pais. No entanto, a autora afirma que as famílias também indicaram preocupações sobre a aprendizagem e desenvolvimento dos filhos e realizaram queixas sobre a não comunicação pela Creche da rotina das crianças. Houve a manifestação, pelas participantes, do desejo de obter mais informações sobre seus filhos e de que, para tanto, ocorresse uma maior abertura da Creche às famílias, uma aproximação entre pais e educadoras, e uma ampliação das suas possibilidades de participação no âmbito institucional.

Notamos, nesse contexto, como a relação entre a Educação Infantil e as famílias é indicada pelas pesquisas como sendo ainda aquém do desejado e preconizado nas legislações e publicações brasileiras, mesmo nos casos em que existem avaliações positivas desta relação. Foram poucos os momentos de encontros entre a Educação Infantil e famílias, avaliados por pais e profissionais como sendo proveitosos para o processo de cuidar e educar a criança 
conjuntamente, como os citados no estudo de Saisi (2010) e Gallo (2010). Ao analisarmos as pesquisas mencionadas acima, notamos que, de uma forma geral, as mesmas indicaram a relação entre a Educação Infantil e famílias como sendo permeada por confrontos e que estariam relacionados a diferentes elementos, tais como a falta de comunicação entre as instituições escolar e familiar e a precariedade de vagas oferecidas às famílias. Os diversos estudos apontaram que tal relação parece se configurar, muitas vezes, a partir de concepções da Educação Infantil como sendo superior aos pais e de ideias sobre as famílias de camadas populares como sendo desinteressadas pela Escola, ausentes no cotidiano escolar e passivas na relação com a instituição escolar.

A relação entre a Educação Infantil e as famílias foi indicada ainda, por estudos, como sendo distanciada. Tal distanciamento ocorreria tanto em casos em que a família não comparece à instituição, como em casos em que a família está presente na mesma, mas que não há formas de comunicação eficientes para a troca de informações.

No entanto, é importante reafirmamos que tais pesquisas foram realizadas em instituições localizadas em contextos urbanos. E em instituições situadas nos territórios rurais, como profissionais e famílias avaliam e vivenciam esta relação? A relação entre a Educação Infantil e famílias do campo aproxima-se do que é preconizado nas legislações nacionais que tratam esta questão?

Conforme discutido anteriormente, a importância de haver uma relação próxima, dialógica e democrática entre a Educação Infantil e as famílias é uma questão abordada e discutida no ECA (1990), na LDB (1996) e nas Diretrizes Curriculares Nacionais para a Educação Infantil (2009) e que deve, dessa forma, ser considerada por todas as instituições de Educação Infantil, seja ela da cidade ou do campo. Documentos da área da Educação do campo - em consonância com o ECA, com a LDB e com as Diretrizes Curriculares Nacionais para a Educação Infantil - também vêm indicando a necessidade de existência de uma relação de qualidade entre a Escola do campo e as famílias (BRASIL, 2002, 2008). Nas Diretrizes Operacionais para a Educação Básica nas Escolas do Campo, afirma-se que o projeto institucional das Escolas deve vincular-se à realidade das comunidades atendidas e garantir a gestão democrática, constituindo mecanismos que possibilitem estabelecer relações entre a Escola e a comunidade local (BRASIL, 2002). O estabelecimento de uma relação próxima entre a Educação Infantil e famílias atendidas é indicado, nas Orientações Curriculares para a Educação Infantil do campo (2010), como parte da função sociopolítica e pedagógica das Creches e Pré-escolas. Para Silva e Pasuch (2010) isso significa 
(...) um posicionamento da instituição no sentido de ter a compreensão de vida a respeito das especificidades dos fazeres educativos, dos cuidados das crianças, assim como das especificidades das famílias. Portanto, os projetos familiares e institucionais se complementam. A ideia de complementaridade reconhece, portanto, a importância das duas instituições, cada uma cumprindo sua função. Isso se traduz em uma abertura da instituição para a participação da família e de sua comunidade, conforme os princípios legais da gestão democrática (SILVA; PASUCH, 2010).

As autoras afirmam que se a participação da família é desejável e necessária nas diversas modalidades de educação, na Educação Infantil ela é indispensável para a qualidade do atendimento considerando-se as características desenvolvimentais das crianças da faixa etária dos 0 a 6 anos de idade. Para tanto, Creches e Pré-escolas no campo devem buscar um profundo conhecimento da comunidade, a partir do estabelecimento de uma relação dinâmica e cotidiana com as famílias, por meio de conversas e de ações planejadas (SILVA; PASUCH, 2010).

A relação próxima, dialógica e cotidiana entre as famílias e a Educação Infantil ofertada no campo é indicada tanto nos documentos reguladores da Educação Infantil (BRASIL, 2009b, 2009f) como da Educação das populações do campo (BRASIL, 2002, 2008). Esta relação é vista como parte de um processo de construção nos últimos anos do que vem sendo chamado de Educação do campo. A legislação atual sobre a educação para os povos do campo (BRASIL, 2002) foi estabelecida a partir das contribuições dos movimentos sociais de luta pela Reforma Agrária, no país, que reivindicam a superação histórica do tratamento dos povos do campo como inferiores, para os quais a educação sempre foi a imposição de um modelo urbano e pouco refletido da realidade do campo. Esse paradigma procura distanciar-se criticamente da chamada Educação rural, que, segundo diversos autores militantes da Educação do campo, esteve ligada aos interesses das classes dominantes e voltada à produção capitalista. A Educação do Campo propõe e expressa um movimento amplo de luta dos povos do campo por uma educação que reconheça o protagonismo desses sujeitos no processo de construção do conhecimento (FERNANDES; MOLINA, 2004; FERNANDES, 2006; CALDART, 2009). Construída pelos movimentos do campo e hoje presente nas regulamentações nacionais, a Educação do Campo prima pela autonomia e saberes dos povos moradores dos territórios rurais. Existem evidentemente debates em torno dessa concepção de educação e sabemos que essa concepção não é necessariamente homogênea entre os meios acadêmicos. Neste trabalho, tomamos como fato que a Educação do campo é o marco legal atual e nos aliamos a uma concepção de Educação Infantil do 
campo tal como proposto por Silva e Pasuch (2010), como sendo aquela voltada para as populações moradoras em territórios rurais e que

(...) valorize suas experiências, seus modos de vida, sua cultura, suas histórias e suas famílias, que respeite os tempos do campo, os modos de convivência, as produções locais. Uma educação infantil que permita que a criança conheça os modos como sua comunidade nomeia o mundo, festeja, canta, dança, conta histórias, produz e prepara seus alimentos. (SILVA; PASUCH, 2010).

Segundo as autoras, a Educação Infantil no campo deve ter o "corpo" e a "alma" do campo, estando articulada aos saberes de seus povos (SILVA; PASUCH, 2010).

Partindo do diálogo com tais publicações e preceitos legais nacionais referentes à Educação Infantil, à Educação Infantil no campo e à Educação do campo, bem como com pesquisas sobre a relação entre a Educação Infantil e famílias no contexto urbano, nos questionamos: Como vem ocorrendo a relação entre a Educação Infantil e as famílias nos territórios rurais?

\subsection{A relação entre a Educação Infantil e as famílias do campo e os objetivos da pesquisa}

“... Ah, eu acho que deveria ter sim, na zona rural. Tipo assim, perto da Escola ter uma Creche...". (Familia do campo)

“... Eu não entendo porque que lá (Escola da cidade) aceita até de quatro anos e aqui não, sendo que é Escola municipal do mesmo jeito, mesma coisa...”. (Família do campo)

Nos itens anteriores, discutimos como a Educação Infantil no Brasil foi se constituindo historicamente como direito da criança e da família, seja da cidade ou do campo, cabendo ao Estado a garantia de vagas em Creches e Pré-escolas para todas as crianças, bem como o oferecimento de um serviço de qualidade. No que tange à Educação Infantil no campo, apontamos ainda como os aparatos legais foram sendo construídos, tanto na área da Educação Infantil como na área da Educação do Campo, para resguardar e regulamentar o direito das famílias rurais a esta modalidade de educação.

No entanto, apesar de tais avanços legais, ainda encontramos, na realidade brasileira, uma carência no que se refere ao oferecimento da Educação Infantil para famílias moradoras 
em territórios rurais e, ainda, uma nítida desvantagem das populações do campo em relação às da cidade no que tange ao acesso às Creches e Pré-escolas. Optamos por iniciar este item com as falas de uma família do campo participante desta pesquisa, por considerar que as mesmas tocam nesta questão. Os relatos da família do campo indicam a necessidade de também haver Creche no campo e constituem-se como uma crítica ao oferecimento desigual da Educação Infantil e que é atravessada pela questão da territorialidade, sendo o mesmo mais precário no meio rural.

Os dizeres da família do campo, que nos remetem à precariedade da Educação Infantil no campo, fazem alusão a uma realidade nacional. Apesar do não acesso à Educação Infantil ser também uma realidade das cidades (CERISARA; ROCHA; SILVA FILHO, 2002), no campo ele vem se configurando de uma forma mais drástica. A desigualdade no oferecimento da Educação Infantil no nosso país é evidenciada por dados do IBGE que indicam que, em 2008, a taxa de frequência à Creche era de 18,1\% e à Pré-escola de 79,8\%, sendo o oferecimento do serviço mais precário para populações rurais e mais pobres. Das crianças de 0 a 3 anos da zona urbana, frequentavam Creche 20,5\%; já na zona rural essa taxa era de $7,2 \%$. Apenas 10,7\% das crianças com renda familiar mais baixa frequentavam Creche, já o percentual das crianças com renda mais alta era de 37,0\%. Das crianças de 4 a 6 anos, 82,2\% das crianças da zona urbana frequentavam Pré-escola, enquanto da zona rural a taxa era de 69,6\%. A taxa de frequência à Pré-escola das crianças mais pobres era de 72,7\% e das mais ricas, de 93,8\% (IBGE, 2009).

No que tange à pobreza, um dos elementos avaliados como estando relacionado ao não acesso das famílias à Educação Infantil, é importante ressaltarmos que a mesma atinge mais drasticamente as populações rurais. Segundo dados organizados pelo Inep, em 2004, cerca de 30,8 milhões de brasileiros viviam no campo em franca desvantagem social. Apenas 6,6\% da população rural economicamente ativa apresentava rendimento real médio acima de 3 salários-mínimos. Na zona urbana, nessa mesma faixa de renda, concentrava-se $24,2 \%$ da população (BRASIL, 2007). Dados da Pesquisa Nacional por Amostra de Domicílios (IBGE, 2009) revelaram que 8,4 milhões de pessoas da população rural total (30,7 milhões de pessoas) eram enquadradas como pobres (renda per capita mensal de até meio saláriomínimo, que em valores de setembro de 2009 correspondia a R 207,50 ); e 8,1 milhões de pessoas eram classificadas como extremamente pobres (renda per capita mensal de até um quarto de salário-mínimo que, em valores de setembro de 2009, correspondia a R\$103,75). Isso significa que, no ano de 2009 , aproximadamente $54 \%$ da população rural total era classificada como pobre. 
Para os especialistas, é nítida a vulnerabilidade da população do campo, resultante do desamparo histórico a que vem sendo submetida, a qual se reflete nos altos índices de analfabetismo, no baixo desempenho escolar (BRASIL, 2007) e na precariedade de vagas em diversas modalidades de educação, como na Educação Infantil.

No que se refere à precariedade de vagas da Educação Infantil no campo, a Pesquisa Nacional da Educação na Reforma Agrária (BRASIL, 2005) apontou que, dentre as crianças assentadas na faixa etária de 0 a 6 anos, apenas $0,1 \%$ frequentava Creche familiar ou informal, 0,8\% frequentava Creche organizada como Escola e 5,1\% frequentavam Préescolas. Silva e Pasuch (2010) afirmam que abrir vagas da Educação Infantil no campo constitui um grande desafio nacional na atualidade, tendo em vista que, em muitas localidades rurais brasileiras, não existe atendimento desse segmento social.

Tal realidade evidencia lacunas na ação do Estado em relação ao compartilhamento do cuidado e educação das crianças com as famílias moradoras em territórios rurais. De acordo com Nascimento (2009), o que constatamos na atual conjuntura brasileira é a ausência de políticas, ditas "públicas", de Educação Infantil em territórios rurais, o que contribui para manter a questão da educação da infância do campo em uma invisibilidade do ponto de vista social, cultural e político.

E do ponto de vista científico, será que a questão da Educação Infantil do campo possui também fraca visibilidade no nosso país? Apesar de termos constatado um aumento do número de pesquisas no Brasil sobre a Educação Infantil (SILVA et al., 2010; STRENZEL, 2000), parece que as mesmas vêm investigando questões e experiências das cidades. A nosso ver, a área da Educação Infantil no Brasil enquanto campo de conhecimento vem se desenvolvendo ancorada em um referencial urbanocêntrico de sociedade. Ao estudarmos a literatura sobre a história da Educação Infantil no Brasil/a história da complementaridade do cuidado e educação da criança entre família e Creches/Pré-escolas, por exemplo, notamos que o ambiente rural é citado pontualmente, sendo destacado como contexto de cuidado e educação da criança quando ainda se constituía como principal local de moradia das famílias brasileiras. Na medida em que se inicia a discussão do crescimento das grandes cidades e do surgimento das primeiras instituições de Educação Infantil, percebemos que o campo praticamente some deste cenário - é como se desparecesse da história da Educação Infantil no Brasil - assim como suas crianças e famílias. A partir de então, discutir Educação Infantil vem predominantemente limitando-se à discussão das demandas, peculiaridades e experiências do contexto urbano. 
A visão urbanocêntrica da Educação Infantil, neste cenário, vem influenciando as trajetórias de pesquisa no Brasil, podendo contribuir para manter crianças e famílias do campo em certa invisibilidade científica. Em 2011, o Ministério da Educação aprovou um projeto de Pesquisa Nacional, ainda em andamento, que tem exatamente como objetivo realizar um mapeamento acerca das práticas educativas ofertadas pelo poder público, famílias e comunidades às crianças de 0 a 6 anos de idade, moradoras em territórios rurais, com vistas a subsidiar políticas nacionais nesta área ${ }^{3}$. A realização de tal projeto foi justificada, tendo em vista a escassez de pesquisas científicas existentes no Brasil sobre a temática e que indicassem como vem se configurando o (não)atendimento das crianças do campo na Educação Infantil.

O presente trabalho foi desenvolvido nesse cenário, caracterizado pela precariedade de pesquisas acadêmicas sobre a Educação Infantil no campo. Identificamos e apresentamos, porém, para a discussão de nosso objeto de estudo, pesquisas que possuíam como objetivo investigar a relação Escola (de uma forma geral) e família (OLIVEIRA, 2009; FARIA, 2007; FERRAZ, 2010). Nessas pesquisas, a Escola rural oferecia o Ensino Fundamental, a Educação Infantil e, em alguns casos, outras modalidades de educação. Identificamos e apresentamos ainda outros estudos que, apesar de não terem como objetivo discutir a relação entre a Educação Infantil e famílias, trazem dados sobre a temática (POJO, 2003; MARTINS, 2009; VARGAS, 2003).

Ao lermos os trabalhos citados acima, é importante mencionarmos que buscamos nos atentar para as formas como a relação entre a Escola (Educação Infantil) e as famílias do campo é concebida, avaliada e discutida, ao longo dos estudos. No caso de pesquisas que tiveram como participantes famílias e profissionais das Escolas, buscamos ainda identificar como, segundo os autores, os mesmos descreveram e vivenciaram essa relação.

Ao analisarmos pesquisas que discutem a relação entre a Escola rural e as famílias do campo, um dado interessante observado foi o fato de tal relação ser indicada como sendo mais próxima do que a observada no contexto urbano (VARGAS, 2003; FARIA, 2007). Segundo Faria (2007), apesar da escassez de estudos na área que possibilitem uma maior compreensão da realidade no campo, parece haver uma relação mais acolhedora e menos dissonante entre

\footnotetext{
${ }^{3}$ Ressaltamos que nós - doutoranda e professora orientadora deste trabalho - compomos a equipe desta Pesquisa Nacional denominada "Caracterização das práticas educativas com crianças de 0 a 6 anos moradoras nos territórios rurais brasileiros". A professora Ana Paula Soares da Silva compõe a coordenação adjunta da Pesquisa Nacional e eu faço parte de uma equipe de pesquisadores, coordenada pela professora Ana Paula Soares da Silva, que é responsável por uma das ações (a Ação 1) desta Pesquisa. A Ação 1 tem como meta a realização de uma pesquisa bibliográfica acerca da produção científica nacional sobre a Educação Infantil no campo. Participam desta pesquisa Universidades Federais e Estaduais do país, a saber: UNEMAT, UFMG, UFRGS, UFCG, UFPA e USP.
} 
as populações de camadas populares e a Escola no meio rural. De acordo com a autora, historicamente, a Escola vem denegrindo e desvalorizando as crianças e famílias das camadas populares, contestando seus valores e sua dinâmica e desqualificando suas ideias, lutas e participação no âmbito escolar. A depreciação das famílias de camadas populares em Escolas urbanas, avaliadas por seus profissionais como sendo desorganizadas, desestruturadas, equivocadas na criação de seus filhos e/ou desinteressadas em relação à Escola, é evidenciada e discutida por diferentes autores (PATTO, 1990; ZAGO, 1997; NOGUEIRA; ABREU, 2004; LIMA, 2008).

Um dos estudos que indica a existência de uma relação mais acolhedora entre Escola e família no meio rural foi o de Vargas (2003). Esta pesquisadora realizou uma investigação com 19 profissionais (que haviam cursado no máximo o $5^{\circ}$ ano do Ensino Fundamental) que exerciam a função docente, atuantes em 14 escolas rurais de Ensino Fundamental e de classes multisseriadas, localizadas nos municípios de Janaúba e Jequitaí (MG), e buscou evidenciar as estratégias pelas quais as professoras rurais aprendem a arte de ensinar. Ao ouvir as histórias de vida e as experiências de professoras rurais, Vargas constatou a existência de um continuum família-escola em territórios rurais, marcado por grande proximidade. A proximidade das professoras atuantes em Escolas rurais com a comunidade contribuía para a realização de práticas que expressavam, nas palavras da autora, "um elevado grau de entendimento da dinâmica sociofamiliar rural e das condições de trabalho no campo" (VARGAS, 2003, p. 99). Dentre essas práticas, a pesquisadora indicou a aceitação pela instituição, que atendia crianças que tivessem acima de 6 anos, de crianças de 4 e 5 anos não inscritas oficialmente nas turmas. A justificativa dada pelas professoras era de que esta era uma forma de liberação da mulher para a realização de trabalhos externos ao âmbito doméstico, como os ligados à agricultura. Além disso, tendo em vista que, no contexto rural investigado, comumente cabia às crianças mais velhas cuidar das mais novas, a ida das crianças pequenas, como as da Educação Infantil, para a Escola junto com seus irmãos que já cursavam o Ensino Fundamental era vista de forma natural pelas professoras, o que permitia a frequência de todas as crianças na instituição escolar. Outra prática que evidenciava a estreita ligação da Escola à realidade das crianças estaria relacionada à alimentação. Segundo Vargas, as professoras, partindo do conhecimento das precárias condições de vida e de subsistência das famílias, buscavam oferecer merenda a todas as crianças. A Escola, dessa forma, complementava as práticas de cuidado das famílias em relação à criança.

O estudo de Faria (2007) também encontrou dados semelhantes à pesquisa de Vargas (2003) referentes à relação Escola e família no meio rural. Faria (2007) realizou uma pesquisa 
com famílias, professoras e direção de uma Escola localizada em um assentamento do MST em Minas Gerais e teve como objetivo descrever e compreender a relação Escola e família. A Escola do assentamento, fundada a partir da mobilização da comunidade, era anexa a uma Escola da cidade e atendia Educação Infantil e as primeiras séries do Ensino Fundamental (1 ${ }^{\text {a }}$ a $4^{\mathrm{a}}$ ), contando com três professoras da comunidade, sendo que duas haviam concluído o Magistério e cursavam Licenciatura em Educação do Campo e uma havia concluído o Ensino Superior em Pedagogia. A supervisora e a diretora não eram da comunidade e possuíam, respectivamente, formação em Pedagogia e em Engenharia Sanitária. A pesquisadora constatou, na realidade investigada, que havia um continuum família-escola, não ocorrendo uma demarcação entre ambiente escolar e familiar. De acordo com famílias e profissionais, o assentamento seria uma grande família, cabendo a todos a responsabilidade pelo cuidado e educação da criança. A não distinção entre Escola e família, a gratidão e a cumplicidade caracterizavam a relação entre profissionais e pais, fazendo com que ocorressem um estreitamento de laços e uma amenização de conflito nessa relação. De acordo com a investigadora, a relação de cumplicidade, oriunda da pertença e participação no MST (tanto das famílias como das professoras), amenizava o convívio e evitava o conflito. O mesmo não ocorria na relação das professoras e famílias com a direção (representantes do Estado na comunidade). A direção, na relação com as famílias, apresentava uma postura assistencialista e de caridade. Para as famílias, a direção era vista de forma indiferente. Já a relação entre direção e professores era tensa e conflituosa, sendo tais conflitos de natureza cultural, política e ideológica. Havia na comunidade o desejo da direção da Escola ser composta por representantes do MST. A pesquisadora concluiu que a principal marca da Escola no assentamento era identitária, sendo a natureza das relações entre famílias e Escola atravessada pelo pertencimento ao MST. No que tange à participação das famílias na Escola, Faria (2007) constatou que as menos participativas seriam aquelas que não se envolviam com a dinâmica do assentamento devido, principalmente, à distância geográfica. Já as famílias mais participativas (a maioria) seriam aquelas que internalizaram as concepções e práticas do MST e que fizeram uma ocupação da Escola, no sentido de se sentirem parte dela.

A prática de ocupação da Escola pelas famílias foi investigada e conceituada por Martins (2009). Segundo o autor, o movimento de ocupação da Escola pelos movimentos sociais é anterior à própria estruturação da instituição escolar e expressa uma consciência dos movimentos do papel da educação para a construção de um novo projeto de sociedade. A ocupação da Escola não se faz distintamente da ocupação da terra, havendo uma articulação destas com um projeto de sociedade. Nesse contexto, a relação entre família e Escola rural, no 
âmbito dos movimentos sociais, é vista como sendo intrínseca à existência e ao funcionamento da instituição escolar.

A existência de uma relação próxima entre famílias e Escola também é indicada em estudos que se propuseram a investigar comunidades ribeirinhas. Pojo (2003) realizou uma pesquisa junto a membros das comunidades (educadores, coordenadores, gestor, pais, líder comunitário) de três Escolas ribeirinhas municipais de Belém - região amazônica, localizadas nas ilhas de Jutuba e Paquetá. As Escolas atendiam Educação Infantil e Ensino Fundamental, sendo que havia a junção de crianças da Educação Infantil e do Ciclo I do Ensino Fundamental em uma mesma sala. Um dos objetivos da pesquisa era caracterizar as práticas pedagógicas presentes nas salas de aula de Escolas ribeirinhas e refletir o quanto as mesmas estavam implicadas com o contexto das comunidades atendidas. A pesquisa indicou que os educadores ora realizavam práticas contextualizadas e prazerosas junto às crianças, ora realizavam práticas que consistiam na transmissão de conteúdos com o uso de livros didáticos. Tendo em vista que as turmas possuíam crianças de níveis de ensino diferenciados, os educadores procuravam diversificar as atividades, respeitando os ritmos das crianças. Segundo a pesquisadora, os educadores buscavam realizar um trabalho pedagógico em diálogo com os saberes das comunidades e com as características locais, havendo uma participação da comunidade na Escola, que a via como um espaço social legítimo de intercâmbio cultural.

Ferraz (2010), ao investigar o cotidiano de uma Escola rural ribeirinha na Amazônia, tendo como participantes do estudo moradores da comunidade e profissionais da instituição escolar, constatou, ao contrário do que foi verificado no estudo de Pojo (2003), que a Escola realizava atividades desconectadas com a realidade local e com os saberes e cultura das comunidades ribeirinhas. As famílias indicaram, contudo, a Escola como sendo uma instituição importante e que possibilitava a construção de conhecimentos relevantes para a ascensão social e melhoria das condições de vida da população rural. Essas concepções foram também defendidas pelos profissionais que afirmaram a importância da Escola enquanto responsável pela socialização e transmissão de conhecimentos acumulados pela humanidade. Famílias e profissionais indicaram, ainda, que a participação da família era restrita aos momentos de reuniões, festas e outros eventos. Profissionais avaliaram que tal participação seria grande, em contraponto ao observado em instituições da cidade, mas indicaram como sendo necessária a efetiva contribuição dos pais na melhoria da qualidade na Escola e na continuidade do trabalho que desenvolvem na instituição escolar. No entanto, indicaram que a construção de uma gestão democrática era dificil, pois a comunidade era evasiva e não 
possuía organização política. Já as famílias mencionaram dificuldades de integração da comunidade para melhor participarem da Escola, mas afirmaram que buscavam ir às atividades na instituição escolar e que gostariam de estar mais presentes no seu cotidiano, o que nem sempre era possível devido às condições de trabalho. No entanto, de uma forma geral, a comunidade foi indicada como participativa na instituição escolar, o que evidenciou proximidades na relação Escola e família.

No estudo de Oliveira (2009), encontramos dados distintos das pesquisas acima mencionadas no que tange à relação entre Escola e famílias no meio rural, sendo esta descrita, pela autora, como permeada por distanciamentos. A pesquisadora realizou um estudo com profissionais, famílias/genitoras e outros membros da comunidade da instituição escolar da Ilha da Marambaia, situada em Mangaratiba, litoral sul do Estado do Rio de Janeiro. A Ilha de Marambaia é, desde 1971, administrada pela Marinha do Brasil que criou e mantém o Centro de Adestramento da Ilha de Marambaia do Corpo de Fuzileiros Navais, o que vem, desde a década de 1980, gerando conflitos pela posse definitiva das terras da Ilha, já que os ilhéus consideram suas como herança de seus antepassados. A Escola da Ilha de Marambaia é municipal e atende Educação Infantil, Ensino Fundamental e Ensino Médio. O objetivo da investigação foi compreender a relação entre a população que lá reside - composta por remanescentes de quilombo, caiçaras - e a Escola, no que tange aos aspectos pedagógicos, aos anseios da comunidade, às questões curriculares e às possibilidades de projeto educacional. Dados da pesquisa indicaram que as famílias possuíam preocupações quanto ao futuro profissional dos filhos da Ilha e a permanência dos mesmos neste local e mencionaram formas de melhorar a qualidade da Escola, para que a mesma estivesse articulada com as necessidades locais (ligadas à pesca), permitindo a formação dos jovens para que os mesmos pudessem continuar e trabalhar na Ilha. Já os profissionais afirmaram que existia um desinteresse das famílias pela escolarização dos filhos e pela melhoria de suas condições de vida, havendo o uso do termo "acomodados" para se referirem às famílias e aos alunos caiçaras. Tanto famílias como profissionais avaliaram a relação entre a Escola e a comunidade como sendo frágil. A participação das famílias no cotidiano escolar se restringia às reuniões de pais, festas ou em situações eventuais devido às questões relativas ao aprendizado e/ou comportamento. Segundo a autora, contribuíam para tal distanciamento questões políticas fortes e tensas na Ilha, como a relação com a Marinha. A Marinha se fazia presente no cotidiano da Escola, realizando, por exemplo, o transporte dos profissionais e alunos nas suas embarcações. O conflito existente entre famílias e Marinha pela posse da terra da Ilha parecia inibir a participação da família na Escola. Uma das famílias, por exemplo, ao manifestar o 
desejo de a Escola oferecer curso profissional de pesca para os jovens continuarem na Ilha, questionou se a Marinha permitiria já que a mesma estaria realizando, na sua concepção, um movimento de expulsão da comunidade da Ilha. Segundo Oliveira (2009), a Escola não atendia, dessa forma, aos anseios e às necessidades da comunidade local, seguindo diretrizes curriculares homogêneas do município, o que contribuía ainda mais para tornar a relação Escola e comunidade como sendo dissonante.

Dessa forma, observamos que as pesquisas acima indicam importantes dados sobre a relação Escola e família no meio rural e nos permitem visualizar como a relação é vivenciada de forma diferenciada nas instituições escolares. Ao contrário do que foi evidenciado em estudos realizados em instituições urbanas, discutidos anteriormente, notamos que a relação Escola e família rural parece ser, de uma forma geral, permeada por menos confrontos e desencontros entre pais e profissionais e que dificultariam o processo de educação conjunta da criança. Notamos, contudo que, nos mesmos, não há uma atenção, uma consideração das especificidades da Educação Infantil no processo de investigação e de discussão dos dados. A Educação Infantil e a relação desta com as famílias possuem características e especificidades, construídas historicamente e discutidas nos itens anteriores deste trabalho, que não são mencionadas nessas pesquisas.

Nesta conjuntura, questionamo-nos sobre como se dá a relação entre a Educação Infantil no campo e as famílias do campo, como se configura a demanda das famílias rurais por Educação Infantil no campo e quais são as significações dos profissionais e pais sobre tal relação.

Nas pesquisas que abordam a relação Escola e família no meio rural e que se propuseram a ouvir profissionais e famílias, outro dado observado é que, muitas vezes, as concepções dos participantes relacionadas à temática se aproximam ou se distanciam, não havendo, porém, uma análise e discussão mais aprofundada nos trabalhos sobre este movimento e como o mesmo contribui ou não para a construção de uma relação próxima e dialógica entre as instituições escolar e familiar e, ainda, para a promoção de uma Educação Infantil no e do campo.

Para nós interessa compreender esses movimentos de aproximação e distanciamento. Partimos da hipótese de que as significações que compõem o universo semiótico dos profissionais da educação e das famílias do campo partilham elementos da matriz sóciohistórica, mas que a relação diferenciada no e com o rural e suas condições materiais de existência circunscrevem também diferentes possibilidades de significações, em relações de proximidade e distanciamento. Interessa-nos investigar esse processo e compreender os 
elementos que compõem e caracterizam a relação família e Escola, no contexto particular do rural.

Assim, tendo em vista esta tese/hipótese, o objetivo geral da pesquisa foi investigar as significações dos participantes do estudo sobre a relação Educação Infantil e família do campo, buscando indicar e compreender se e como as significações de profissionais e famílias se aproximam e se distanciam. Ao olharmos para tais movimentos de aproximações e distanciamentos das significações, pretendemos evidenciar em que medida os mesmos contribuem ou não para a melhoria da relação Escola e família, em consonância com os pressupostos legais sobre a temática. Como objetivos específicos, procuramos investigar as significações de profissionais e das famílias do campo em relação: à (não)demanda de Educação Infantil no campo; aos objetivos e à relevância da Educação Infantil no campo para as crianças e famílias; aos momentos de (des)encontros entre a Educação Infantil no campo e as famílias do campo, buscando compreender dificuldades, facilidades, tensões e desafios relacionados a tais momentos.

Com a realização deste estudo, almejamos contribuir com a construção de conhecimentos sobre a relação entre a Educação Infantil e família rural e procuramos nos aliar aos movimentos atuais que vêm se configurando no âmbito nacional na busca por conhecer e dar visibilidade à Educação Infantil que vem sendo realizada no campo. 


\section{CAPÍTULO}

3

METODOLOGIA

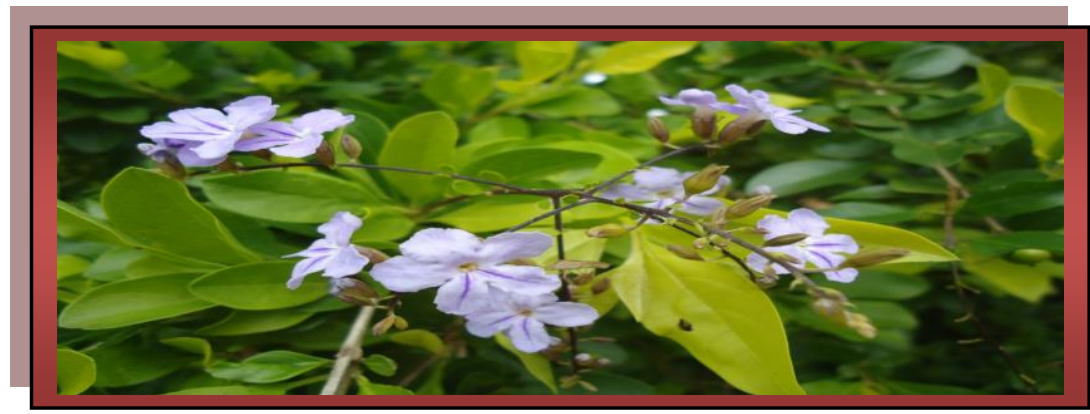





\section{METODOLOGIA}

Esta pesquisa parte de um pressuposto fundamentado na perspectiva vygotskyana que considera que o método é concomitantemente pré-requisito e produto (VYGOTSKY, 1984). O autor russo, em diálogo com Marx, afirma que o método é algo a ser praticado e não aplicado. Ambos rejeitam a ideia de método como sendo um meio para um fim ou um instrumento para obter um resultado, sendo, na visão dos autores, "instrumento-e-resultado".

\subsection{Os instrumentos da pesquisa e o pesquisador}

A perspectiva da RedSig, conforme discutido anteriormente, permite afirmar que as interações humanas e os processos de significações são atravessados e circunscritos por elementos pessoais, contextuais e da matriz sócio-histórica a que estão intrinsecamente relacionados. Nessa perspectiva, cabe ao investigador considerar a complexidade intrínseca dos fenômenos ao longo do processo de investigação. Para tanto, Rossetti-Ferreira et al. (2004, 2008) ressaltam que é necessário ao investigador, a depender de seu objeto de estudo, utilizar diferentes instrumentos de pesquisa, tais como entrevistas, videogravações, observações, análise de documentos e outros. A utilização de diversos instrumentos de pesquisa pode possibilitar a construção de dados distintos e que se relacionam a diferentes nuanças do fenômeno investigado, enriquecendo nosso entendimento sobre o mesmo.

As autoras da RedSig vêm defendendo o conceito discutido por Newman e Holzman (2002) e inspirado em Vygotsky de pesquisador ferramenteiro, ou seja, aquele que constrói seu instrumento de pesquisa, bem como as formas de sua utilização ao longo da investigação. Neste cenário, a pesquisa é vista também como um processo criativo do pesquisador, que a todo o momento (re)formula sua metodologia de trabalho, para a melhor compreensão do objeto investigado.

No presente trabalho, para respondermos às questões levantadas, utilizamos os seguintes instrumentos de pesquisa: entrevistas e observações. 


\subsubsection{A entrevista}

Para iniciarmos nossa discussão sobre a entrevista enquanto instrumento de pesquisa, consideramos importante destacar sua natureza dialógica. A entrevista é, primordialmente, uma interação humana e um importante momento de produção de sentidos pelos participantes sobre temas abordados. Daí decorre, a nosso ver, seu principal objetivo e qualidade: a investigação das significações.

Partindo dos pressupostos defendidos pela RedSig de que o desenvolvimento humano se dá nas e pelas interações, consideramos ainda que o momento da entrevista também se constitui como possibilidade de desenvolvimento para os participantes: entrevistador e entrevistado. Partimos da ideia de que, enquanto interação humana, a entrevista possibilita processos de (re)ssignificação, pelos participantes, sobre si, sobre o outro e sobre o mundo.

Assim como outras interações humanas, ressaltamos que a entrevista é atravessada por elementos pessoais, contextuais e da matriz sócio-histórica. Dessa forma, consideramos, por exemplo, que os cargos profissionais ocupados pelo entrevistado e entrevistador, o sexo dos participantes, o local onde a pesquisa é feita, o período histórico de sua realização e os significados existentes na cultura dos participantes sobre a temática abordada são alguns elementos importantes que constituem a interação no momento da entrevista. Defendemos a ideia de que tais elementos pessoais, contextuais e da matriz sócio-histórica circunscrevem possibilidades de interações entre os participantes e de produção de sentidos sobre assuntos abordados.

Destacando o fato de que concebemos que os sentidos sobre o tema da pesquisa são construídos ao longo da entrevista, entendida como interação humana, e em contextos sóciohistóricos específicos, fica evidente que, para a RedSig, a entrevista não tem como objetivo coletar "dados preexistentes na realidade", mas sim possibilitar a construção de conhecimentos sobre a temática investigada. Conforme pontua Silva (2003), o pesquisador

\footnotetext{
(...) não é concebido como alguém que de fora da situação, produz conhecimento sobre ela. Ele está implicado nesse processo de produção da narrativa do participante, com suas intervenções, sorrisos, posturas, enfim, com a simples presença e com os discursos que essa presença evoca quando e no confronto com o participante. Discursos sobre a cor da pele, gênero, classe social, profissão (SILVA, 2003, p. 79).
}

Nesse cenário, pesquisador e participante são considerados como pessoas ativas ao longo da entrevista. 
$\mathrm{Na}$ presente pesquisa, a entrevista teve como objetivo investigar significações construídas por profissionais da Educação Infantil e por famílias do campo sobre a relação entre a Educação Infantil no campo e famílias do campo. Para sua realização, foram formulados guias de entrevista, que continham tópicos abordados ao longo da entrevista (Apêndices A, B e C).

\subsubsection{A observação}

Consideramos que a observação também possui como característica fundamental seu caráter interacional. Observar pressupõe o estabelecimento de interações entre o pesquisador e aspectos dos contextos investigados, tais como objetos e pessoas. A nosso ver, observar é se relacionar.

Entendemos que a observação é um importante instrumento de pesquisa, pois permite ao pesquisador investigar elementos de naturezas distintas. Defendemos a ideia de que a observação possibilita o conhecimento de significações e, ainda, de aspectos relacionais e materiais que se concretizam no cotidiano dos contextos estudados.

Ao adentrar no seu campo de investigação, por exemplo uma instituição, o pesquisador poderá observar sua estrutura, a organização espacial dos objetos, as atividades realizadas, as significações presentes no cotidiano, as interações estabelecidas entre os diversos atores presentes no cenário. Pensamos que o conhecimento destes diferentes elementos pode auxiliar o investigador na compreensão de temáticas relacionadas com a dinâmica institucional. O levantamento de dados sobre o contexto investigado pode ainda contribuir com outros momentos da pesquisa como, por exemplo, na elaboração dos guias de entrevistas a serem realizadas com membros do contexto estudado.

Destacamos que, no processo de investigação, conforme evidenciado anteriormente, o pesquisador/observador não é neutro, mas sim ativo no processo de investigação. No caso da observação, acreditamos que os saberes do pesquisador (apropriados na sua inserção na cultura) e suas características influenciam seu olhar no campo de estudo. Elementos pessoais atuariam como circunscritores no processo de observação, delimitando possíveis olhares do pesquisador para e sobre o cenário investigado.

Pensamos ainda que outros elementos, como os que compõem o contexto investigado, podem se constituir como circunscritores no processo de observação. Ao adentrar em uma instituição, por exemplo, o pesquisador poderá, devido a normas ou concepções desta instituição, ser convidado a participar de determinados ambientes, podendo, entretanto, ter sua 
circulação limitada ou até restrita em outros cenários, o que delimita possibilidades de construção de dados sobre o cotidiano institucional.

Dessa forma, destacamos a observação como sendo um processo interativo, contextualizado e circunscrito, construído ao longo do processo de pesquisa, e que permite o conhecimento do investigador a respeito de diversos aspectos da situação investigada.

Tendo em vista a diversidade da natureza dos dados construídos na observação, destacamos a possibilidade de existência de diferentes formas de registro, pelo pesquisador, dos mesmos. Consideramos de fundamental importância o registro sistemático dos dados construídos pelo observador ao longo da pesquisa, como forma de garantir o rigor metodológico do estudo.

$\mathrm{Na}$ presente pesquisa, a observação foi realizada nas instituições que ofereciam Educação Infantil no campo e nas residências das famílias do campo. Os dados construídos nas observações foram registrados em diário de campo. No diário de campo, foram registrados dados dos ambientes investigados, bem como impressões pessoais.

No próximo item propomos discutir a construção do corpus da pesquisa, o que amplia o entendimento de como os instrumentos de investigação foram utilizados ao longo do estudo.

\subsection{A construção do corpus da pesquisa}

A presente pesquisa foi realizada junto a uma Escola localizada no campo, que chamaremos de Escola Flamboyant ${ }^{4}$, e famílias atendidas por esta instituição escolar. A Escola está situada em um município do Estado de Minas Gerais, e que denominaremos de município A.

Inicialmente, para a escolha do município para o desenvolvimento do estudo, realizamos uma sondagem, feita por nós em 2010 em 10 cidades do Triângulo Mineiro/Minas Gerais, na qual contatamos, por via telefônica, coordenadores da Educação ou da Educação Infantil dos municípios com o intuito de verificarmos se e como estava ocorrendo o

\footnotetext{
${ }^{4}$ Ao iniciar a pesquisa, pensei o quanto seria bom adentrar no campo, que imaginava estar repleto de ipês amarelos - árvores típicas da região. No entanto, para minha surpresa, na maioria dos trajetos, o que vi - além de grandes empresas - foram árvores grandes com flores vermelhas, que depois descobri que se chamavam Flamboyant. No trajeto da Escola, que selecionamos para dar prosseguimento à pesquisa, algumas dessas árvores me serviram como referência para chegar à mesma. Dentro desta instituição também podíamos desfrutar de sua presença. Dessa forma, resolvi chamar a Escola, em que permaneceria mais tempo, de Escola Flamboyant e, por isso, na capa do presente trabalho apresento a foto da flor desta árvore. Cabe pontuar que não é minha intenção fazer uma analogia da Escola com árvores floridas. Pensei neste nome, pois o mesmo remete a elementos do contexto pesquisado.
} 
atendimento das crianças do campo na Educação Infantil. Para tanto, questionamos se havia o atendimento e, em caso positivo, para qual faixa etária e em qual contexto (cidade e/ou campo).

A partir da realização dessa sondagem, verificamos que:

- 1 município oferecia o atendimento para crianças de 4 a 5 anos do campo no próprio campo e na cidade;

- 4 municípios transportavam crianças do campo para instituições na cidade, sendo que destes 3 transportavam crianças de 4 a 5 anos e 1 crianças de 0 a 5 anos;

- 5 municípios ofereciam Educação Infantil no campo, sendo que em 4 havia o atendimento de crianças de 4 a 5 anos e em 1 de crianças de 0 a 5 anos.

Nos municípios que ofereciam Educação Infantil no campo, o número de instituições existentes nesse contexto variava de 2 a 13 .

O município A era um dos que atendia crianças do campo no campo, destacando-se neste cenário, pois era o que possuía o maior número de instituições no campo - 13 instituições - e o que atendia crianças de 0 a 5 anos. Tendo em vista o objetivo da presente pesquisa, optamos, então, pela escolha desse município para a realização do estudo, já que consideramos que havia ali uma política pública de Educação Infantil voltada para o atendimento das famílias rurais e práticas de complementaridade do cuidado e educação da criança do campo entre famílias e instituições de Educação Infantil no campo.

Depois da escolha do município para a realização da pesquisa, entrei em contato, por via telefônica, com a coordenadora de Educação Infantil do município $A$ e agendamos um encontro, para que pudesse explicar o estudo e solicitar autorização para a realização do mesmo. Neste encontro, a coordenadora de Educação Infantil aprovou a proposta de realização da pesquisa, prontificando-se a auxiliar para sua consecução. Posteriormente, em outro momento, apresentei o projeto escrito e os Termos de Autorização para o desenvolvimento do estudo (Apêndice D), que foram assinados pela Coordenadora de Educação Infantil e pelo Secretário de Educação.

Após definir e acordar a realização da pesquisa junto à Secretaria de Educação do município $A$, comecei a planejar as visitas às instituições do campo que possuíam Educação Infantil. Minha intenção, naquele momento, era realizar uma visita a todas as instituições de Educação Infantil no campo, para conhecê-las, por meio de observações e entrevistas com as diretoras/coordenadoras. Com a realização desses procedimentos, pretendia levantar elementos do contexto (município) no qual a pesquisa seria desenvolvida e, ainda, 
selecionar uma das instituições para iniciar a investigação sobre a relação entre a Educação Infantil e as famílias do campo.

Sabendo de minha intenção de visitar as instituições do município de Educação Infantil no campo, a coordenadora de Educação Infantil me forneceu uma listagem de todas as instituições de Educação Infantil existentes no campo, na qual continha os endereços e telefones de contato, e solicitou que sua secretária avisasse, a todas as diretoras/coordenadoras das mesmas, sobre minha ida. A coordenadora forneceu ainda um documento, destinado às instituições, que afirmava que a pesquisa tinha sido autorizada pela Secretaria de Educação, desde que, ao final do estudo, os dados fossem apresentados à mesma.

Com a realização desses procedimentos junto à Secretaria de Educação do município, comecei então a minha longa e, a meu ver, aventureira, ida às instituições do campo. As mesmas se localizavam em diferentes pontos do município, sendo que o tempo para chegar até elas, depois de sair da cidade, variava de 20 minutos a 2 horas. As condições de acesso também eram diferentes, sendo que, para chegar a algumas instituições, contávamos com estradas asfaltadas, na maioria do trajeto, enquanto para chegar a outras, havia somente estrada de chão. Em muitos pontos desses trajetos, não havia sinal de telefonia móvel.

Antes de ir às instituições, telefonei para diretoras/coordenadoras das mesmas e agendei os encontros. No entanto, motivos diversos, tais como o não funcionamento do telefone de instituições, fizeram com que fosse sem dia e horário agendados em algumas delas. Porém, o fato de ter ou não agendado com as diretoras/coordenadoras não foi decisivo para o encontro com as mesmas. Houve casos que, mesmo tendo marcado com antecedência, ocorreu de, ao chegar à instituição, não encontrar a diretora, que teria saído para resolver assuntos institucionais. Aconteceram ainda situações em que, apesar de não ter confirmado, por telefone, dias e horários possíveis de participação da diretora/coordenadora na pesquisa, ao chegar à instituição, tal encontro e participação foram possíveis. De qualquer forma, nos casos em que não foi possível realizar entrevistas com as diretoras/coordenadoras, fizemo-las com suas representantes, tais como vice-diretora, pedagoga e supervisora. A seguir, apresentamos o Quadro 1 que indica o total de instituições visitadas e os cargos das pessoas que participaram da pesquisa em cada instituição. 


\begin{tabular}{|c|c|}
\hline INSTITUIÇÃO & CARGO DA ENTREVISTADA \\
\hline $\mathbf{A}$ & Coordenadora \\
\hline B & Coordenadora \\
\hline C & Coordenadora \\
\hline D & Vice-diretora \\
\hline $\mathbf{E}$ & Coordenadora \\
\hline $\mathbf{F}$ & Supervisora \\
\hline G & Diretora \\
\hline $\mathbf{H}$ & Diretora \\
\hline I & Pedagoga \\
\hline $\mathbf{J}$ & Pedagoga \\
\hline $\mathbf{L}$ & Diretora \\
\hline M & Diretora \\
\hline $\mathbf{N}$ & Diretora \\
\hline
\end{tabular}

Quadro 1 - Cargo das entrevistadas nas instituições que ofereciam, no município, Educação Infantil no campo

Ao todo, foram realizadas 13 entrevistas. Tais entrevistas foram feitas nas próprias instituições e no horário de funcionamento das mesmas, o que contribuiu para que muitas fossem interrompidas algumas vezes para que as profissionais pudessem resolver situações do cotidiano institucional. Por se tratar de um primeiro e único encontro, solicitei e realizei a gravação das entrevistas em casos que percebi que a minha relação com a participante estava tranquila e que não havia receios, por parte das entrevistadas, em relação à pesquisa. Destacamos que, das 13 entrevistas, 9 foram gravadas em aparelho digital.

As entrevistas tiveram como objetivo investigar aspectos dos contextos institucionais, tais como: informações gerais sobre a instituição (histórico, localização, horário de funcionamento, estrutura, tipo de vinculação com a Prefeitura); transporte das crianças; profissionais; oferecimento da Educação Infantil no campo; crianças atendidas (faixa etária e número); famílias atendidas (ocupação, nível socioeconômico).

Em todas as visitas, foram realizadas anotações em diário de campo que se referiam às falas de profissionais, aos dados do contexto institucional e às impressões pessoais. $\mathrm{O}$ material obtido nessa fase da pesquisa influenciou na seleção de questões a serem investigadas nas demais fases do estudo. Tais dados possibilitaram ainda caracterizarmos o contexto no qual a Educação Infantil era oferecida no campo para as crianças e famílias rurais (ver item 4.2. A Educação Infantil no campo do município A) e foram utilizados para a seleção da instituição na qual iríamos prosseguir a investigação.

Após as idas às instituições que ofereciam Educação Infantil no campo, selecionamos então a Escola Flamboyant para dar prosseguimento à construção dos dados. Esta instituição era uma Escola de Ensino Fundamental que possuía uma sala de crianças de 5 anos. A seleção da Escola Flamboyant se justificou pelo fato de a mesma atender a famílias com diferentes 
ocupações profissionais (fazendeiros; funcionários de fazendas; acampados; assentados; trabalhadores em indústrias), conforme será mais bem discutido no item 4.3. A Escola Flamboyant. Considerando os objetivos do presente estudo achamos que seria interessante ter como participantes da pesquisa famílias que viviam em diferentes contextos e condições sociais e econômicas. Além da Escola Flamboyant, outras instituições também apresentaram essa diversidade no que tange à ocupação e ao local de moradia das famílias (ver Quadros 9, 10 e 12). No entanto, escolhemos a Escola Flamboyant, dentre essas instituições, por considerarmos que ela atendia a nosso critério de seleção e, além disso, possuía melhores condições de acesso que as demais.

Após a escolha da instituição para a realização do estudo, solicitei autorização à gestora da Escola Flamboyant para dar continuidade à pesquisa. A diretora se mostrou simpática e colaborativa, autorizando o prosseguimento do estudo. A partir desse momento, iniciei as visitas à Escola Flamboyant, que ocorreram durante 4 meses. No primeiro mês as visitas foram semanais, sendo intensificadas nos meses posteriores. As visitas tinham como objetivo conhecer a estrutura e a dinâmica da instituição. Para tanto, observei aspectos gerais da Escola e participei de atividades que envolviam todas as crianças e famílias atendidas. No entanto, na maioria das visitas, observei a dinâmica e o cotidiano da sala de Educação Infantil e aspectos relacionados ao atendimento desta faixa etária. Nessas visitas, diversos aspectos do contexto institucional foram observados, tais como: estrutura da Escola e da sala de Educação Infantil; atividades realizadas com as crianças; transporte das crianças e dos profissionais; relação entre as crianças e entre as crianças e os profissionais; relação com as famílias.

No que tange às famílias atendidas pela instituição, busquei, ao longo das visitas à Escola Flamboyant, conhecer os familiares das crianças de 5 anos, bem como observar a participação dos mesmos no cotidiano escolar. Nesse momento do estudo, procurei ainda selecionar as famílias para participarem do mesmo. Essa fase da pesquisa será descrita no item 3.2.1. A seleção e a ida às famílias do campo.

Nessa etapa da pesquisa, foram ainda explicados aos profissionais da Escola os objetivos da pesquisa e foram estabelecidas relações de proximidade com os mesmos. Posteriormente, todos os gestores e professores ${ }^{5}$ da Educação Infantil foram convidados para participar da pesquisa. Foram feitas entrevistas com 6 profissionais: 1 diretora, 2 vicediretoras (uma era vice-diretora no período vespertino; a outra exercia este cargo no período

\footnotetext{
${ }^{5}$ Utilizaremos, no presente trabalho, os termos professor e educador adotados pelo município no qual a pesquisa foi realizada. O professor é o profissional que atua na Escola de Ensino Fundamental ou na de Educação Infantil e que possui nível superior de ensino. Já o educador é aquele que atua em instituições específicas de Educação Infantil e que possui formação em nível médio.
} 
matutino e, ainda, era professora da Educação Infantil no período vespertino), 1 pedagoga e 2 professoras da Educação Infantil ${ }^{6}$. As entrevistas com as profissionais da Escola Flamboyant tiveram como objetivo investigar as seguintes temáticas: a Escola/Educação Infantil (objetivos; oferecimento da Educação Infantil no campo); as famílias atendidas e a relação Escola e famílias do campo.

Apesar de sugerir a realização das entrevistas em locais e/ou horários diferentes daqueles de trabalho das participantes, as mesmas optaram pela realização das entrevistas na Escola e em horários em que não estavam exercendo suas atividades. Antes da realização das entrevistas, foram apresentados às participantes os Termos de Consentimento Livre e Esclarecido (Apêndice D), sendo os mesmos discutidos e assinados.

Após a realização das entrevistas solicitei à diretora da Escola Flamboyant documentos da instituição. A mesma forneceu o Projeto Político-Pedagógico da Escola de 2007 e o Regimento Interno da Escola de 2010, disponibilizados na forma digital.

Ao longo das visitas à Escola Flamboyant, todos os dados construídos foram anotados em diário de campo.

\subsubsection{A seleção e a ida às famílias do campo}

Conforme afirmado anteriormente, pretendíamos ter como participantes da pesquisa famílias que viviam em diferentes contextos e condições sociais. Para tanto, fazia-se necessário conhecer onde as mesmas moravam e com o que trabalhavam.

Ao longo das visitas à Escola Flamboyant, busquei então obter informações sobre as famílias das crianças de 5 anos e, mais especificamente, sobre suas ocupações e locais de residências. No entanto, ao conversar com os profissionais da Escola, constatei que os mesmos não tinham estes dados. No cadastro dos alunos existentes na instituição, também não havia informações sobre a ocupação das famílias, havendo somente o endereço que, muitas vezes, era difícil de ser localizado, já que se referiam, por exemplo, a nomes de fazendas.

Durante as visitas à Escola, procurei ainda verificar a presença das famílias das crianças na instituição, para que pudesse conhecê-las. No entanto, ao longo da pesquisa, pude entrar em contato, no âmbito escolar, com mães de crianças de apenas 4 famílias da Educação

\footnotetext{
6 Um dos participantes da pesquisa era do sexo masculino. Porém, com o intuito de evitar possíveis identificações, ou seja, por questões éticas, iremos nos referir a todos os participantes da pesquisa no feminino (Exemplos: as entrevistadas, as profissionais).
} 
Infantil $^{7}$, sendo que 2 destas depois vieram a participar do estudo (mãe de Flávio ${ }^{8}$ e mãe de Fabrício), conforme será mais bem relatado no item 4.4. As famílias atendidas pela Escola Flamboyant e participantes da pesquisa.

Neste cenário, para que pudesse localizar as moradias das crianças e das suas famílias, para dar prosseguimento à pesquisa, optei por ir buscá-las juntamente com os motoristas das vans e ônibus, que realizavam o transporte na Escola. Estes saíam mais cedo da instituição escolar e depois retornavam com as crianças. A instituição contava com aproximadamente 13 vans e com 2 ônibus escolares, que eram contratados pela Prefeitura e disponibilizados à Escola para o transporte dos profissionais e das crianças. Porém, a partir de conversas com os profissionais da Escola, pude verificar que não havia, na instituição, uma listagem na qual constassem quais veículos as crianças utilizavam. Muitos motoristas também não sabiam o nome e/ou a idade das crianças que transportavam.

Dessa forma, para localizar os locais de residência das crianças da Educação Infantil, tive de realizar diversas estratégias, a saber:

1) Perguntei para todas as crianças da Educação Infantil o nome dos motoristas que as transportavam. Algumas não souberam informar, outras me disseram quais eram seus motoristas. Fui, então, aos veículos destes motoristas, indicados pelas crianças;

2) Descobri, observando as crianças no horário de saída, em quais veículos algumas entravam. Posteriormente, em outro dia, fui com estes veículos buscar as crianças em casa. Destacamos que verificar qual veículo era utilizado pelas crianças era uma tarefa dificultada devido à forma como as crianças iam para as vans e ônibus: após a instituição tocar o sinal, que indicava o encerramento do dia escolar, muitas crianças saíam das suas salas sozinhas e, muitas vezes, correndo na direção do transporte que iria levá-las;

3) Fui aleatoriamente, em alguns veículos da Escola, buscar as crianças em suas residências;

4) Segui, com veículo próprio, uma das vans no horário de saída, para ver onde ia deixar uma das crianças da Educação Infantil. Neste caso, cabe ressaltar, que houve o consentimento do motorista para que pudesse acompanhá-lo.

\footnotetext{
${ }^{7}$ Conheci estas famílias (mães das crianças) em momentos distintos: uma em um dia que a genitora veio deixar o filho na Escola; duas mães em um evento promovido pela Escola e outra mãe em uma reunião realizada pela instituição escolar. Destacamos que no evento e na reunião realizados pela e na Escola, nos quais estive presente, não pude identificar se havia outras famílias de crianças da Educação Infantil, já que em tais momentos todas as famílias atendidas pela Escola se encontravam "misturadas". Consegui identificar três famílias das crianças de 5 anos por vê-las, ao longo do evento realizado e ao deixar o filho na Escola, junto às suas crianças, as quais já reconhecia como sendo da Educação Infantil. Identifiquei outra mãe a partir de uma conversa informal antes da reunião realizada pela instituição escolar.

${ }^{8}$ Por questões éticas, todos os nomes, apresentados no presente trabalho, são fictícios.
} 
Utilizadas as estratégias mencionadas anteriormente, pude conhecer onde diversas crianças da Educação Infantil e suas famílias moravam: fazendas, vilas em indústrias e assentamentos. Escolhemos então 5 destas famílias para serem convidadas para participarem da pesquisa, sendo que duas delas já havia conhecido na Escola, conforme citado anteriormente.

Após escolher as famílias participantes da pesquisa fui às suas residências. Essa etapa da pesquisa se apresentou como um desafio, pois o acesso às mesmas, em alguns casos, não foi fácil. Dirigir no campo se constituiu como uma experiência nova, já que ainda não havia passado, na condição de motorista do carro, em mata-burros, pontes - estreitas e rústicas - e por locais onde não avistava pessoas/moradias/comércio. Além disso, apesar de ter ido algumas vezes com os veículos da Escola para memorizar os trajetos, em alguns casos, devido às chuvas, tive de modificar a rota. Em outros, tive dificuldades de lembrar os caminhos. Dessa forma, algumas vezes fiquei perdida e tive de contar com a ajuda de pessoas que fui encontrando no trajeto.

De qualquer forma, consegui ir até as 5 famílias. Ao chegar as suas residências apresentei os objetivos da pesquisa para os responsáveis das crianças que se encontravam em casa, e os convidei para participarem do estudo. Todos aceitaram e, após assinarem os Termos de Consentimento Livre e Esclarecido (Apêndice E), realizamos as entrevistas que foram gravadas em aparelho digital. Ao todo, foram realizadas 5 entrevistas com as famílias do campo, ou seja, uma com cada família. Tais entrevistas tiveram o intuito de investigar as seguintes temáticas: a família (origem; trajetórias; configuração; ocupação; cotidiano); a Escola/Educação Infantil (objetivos; oferecimento da Educação Infantil no campo); a relação Escola e famílias do campo.

Nas visitas às famílias, foram ainda observados elementos dos contextos nos quais as famílias residiam, que foram registrados em diário de campo. Maiores informações sobre as famílias que participaram do estudo, bem como dados sobre as mesmas no momento da pesquisa, serão discutidos no item 4.4. As famílias atendidas pela Escola Flamboyant e participantes da pesquisa.

Para que o leitor possa visualizar o caminho percorrido ao longo de toda a pesquisa, desde a escolha do município até a realização das visitas à Escola Flamboyant e às famílias do campo, apresentamos o Quadro 2: 


\begin{tabular}{c|c}
\hline MÂE & ATIVIDADES(S) \\
\hline Abril de 2010 & Escolha do município para realização da pesquisa \\
\hline Julho de 2010 & Autorização da Secretaria de Educação para a realização da pesquisa \\
\hline Agosto de 2010 & Visitas às instituições que ofereciam EI no campo \\
\hline Setembro de 2010 & $\begin{array}{c}\text { Visitas às 13 instituições que ofereciam EI no campo e escolha da } \\
\text { instituição para realização da pesquisa (Escola Flamboyant) }\end{array}$ \\
\cline { 2 - 2 } & Autorização da pesquisa pela Escola Flamboyant \\
\cline { 2 - 2 } & Visitas à Escola Flamboyant /Observação \\
\hline Outubro de 2010 & Visitas à Escola Flamboyant /Observação \\
\hline Novembro de & Visitas à Escola Flamboyant /Observação \\
2010 & Visitas às Famílias/ Entrevistas \\
\hline Dezembro de 2010 & Visitas à Escola Flamboyant /Observação \\
& Visitas à Escola Flamboyant /Entrevistas \\
& Visitas à Escola Flamboyant/ Obtenção de documentos institucionais \\
\hline
\end{tabular}

Quadro 2 - Cronograma de execução da pesquisa

\subsection{Os participantes da pesquisa}

Conforme apresentado no item anterior, a ida às instituições que ofereciam Educação Infantil no campo no município ocorreu em dois momentos distintos. Em um primeiro momento, realizei visitas às instituições do campo que ofereciam Educação Infantil (n=13) e, em um segundo momento, realizei visitas à Escola Flamboyant, bem como às famílias atendidas por esta instituição.

Nesse primeiro momento de ida às instituições no campo, tivemos como participantes 13 gestoras de instituições localizadas no campo do município A e que ofereciam Educação Infantil, sendo as mesmas diretoras/coordenadoras das instituições ou suas representantes. Não utilizamos nomes fictícios para nos referirmos a estas participantes, pois, conforme será mais bem discutido no próximo item, os dados construídos neste momento da pesquisa são apresentados de forma compilada.

Já no segundo momento da pesquisa, realizado na Escola Flamboyant, tivemos como participantes profissionais desta instituição, a saber: 1 diretora, 2 vice-diretoras (sendo que 1 era também professora da Educação Infantil), 1 pedagoga e 2 professoras. Enfatizamos que a maioria destas profissionais - diretora, vice-diretoras e 1 professora - trabalhava há muito tempo na instituição (mais de 10 anos). No entanto, a pedagoga e 1 professora estavam na Escola Flamboyant há pouco tempo (menos de 1 ano).

Ainda nesse momento do estudo, participaram da pesquisa 5 famílias, moradoras no campo, cujas crianças de 5 anos eram atendidas na Escola Flamboyant. Das 5 famílias participantes do estudo, 1 morava em um assentamento rural, 2 residiam em uma área de uma indústria granjeira e 2 moravam em fazendas e eram funcionárias das mesmas. Destas 
famílias, participaram do estudo 5 mães, 1 pai e 1 avó. Vale destacar que a participação do pai e da avó foi pontual (ver item 4.4. As famílias atendidas pela Escola Flamboyant e participantes da pesquisa).

Para facilitar a identificação das falas das profissionais e famílias da Escola Flamboyant, bem como de pessoas citadas pelas mesmas, optamos por utilizar nomes fictícios cujas iniciais se relacionam de alguma forma com as participantes e com as pessoas mencionadas nas entrevistas, conforme apresentado a seguir:

1) Nomes fictícios das profissionais da Escola Flamboyant: As letras iniciais dos nomes fictícios correspondem às letras iniciais dos cargos ocupados pelas participantes na Escola Flamboyant.

\begin{tabular}{c|c}
\hline CARGO PROFISSIONAL & NOME FICTÍCIO \\
\hline Diretora & Dirce \\
Vice-diretora & Vivian \\
Vice-diretora & Vilma \\
Pedagoga & Patrícia \\
Professora & Paula \\
Professora & Poliana \\
\hline
\end{tabular}

Quadro 3 - Nomes fictícios utilizados para identificar as profissionais da Escola Flamboyant

2) Nomes fictícios das famílias atendidas pela Escola Flamboyant: As letras iniciais dos nomes dos membros das famílias do campo correspondem às letras iniciais dos locais onde as famílias residiam. 


\begin{tabular}{|c|c|c|}
\hline $\begin{array}{c}\text { LOCAL DE MORADIA DA } \\
\text { FAMÍLIA }\end{array}$ & MEMBRO DA FAMÍLIA & NOME FICTÍCIO \\
\hline \multirow[t]{4}{*}{ Fazenda } & Criança da EI & Fabrício \\
\hline & Mãe & Fabíola \\
\hline & Avó & Fabiana \\
\hline & Avô & Fabiano \\
\hline \multirow[t]{3}{*}{ Fazenda } & Criança da EI & Flávio \\
\hline & Mãe & Flaviana \\
\hline & Pai & Flaviano \\
\hline \multirow[t]{3}{*}{ Indústria } & Criança da EI & Iago \\
\hline & Mãe & Inês \\
\hline & Pai & Inácio \\
\hline \multirow[t]{3}{*}{ Indústria } & Criança da EI & Íris \\
\hline & Mãe & Irene \\
\hline & Pai & Irineu \\
\hline \multirow[t]{4}{*}{ Assentamento rural } & Criança da EI & Artur \\
\hline & Mãe & Adriana \\
\hline & Pai & Adriano \\
\hline & Irmã & Alice \\
\hline
\end{tabular}

Quadro 4 - Nomes fictícios utilizados para identificar membros das famílias do campo

As formas de análise do material construído junto as participantes da pesquisa, citados acima, são apresentadas a seguir.

\subsection{Procedimentos de análise}

No presente trabalho, foram analisados materiais construídos nas visitas às instituições de Educação Infantil no campo do município $A$, nas visitas à Escola Flamboyant e nas visitas às famílias do campo, sendo os mesmos: diário de campo e entrevistas. A seguir, apresentamos o Quadro 5 que traz informações sobre o número de entrevistas realizadas e analisadas.

\begin{tabular}{c|c}
\hline ENTREVISTADAS & NÚMERO DE ENTREVISTAS \\
REALIZADAS E ANALISADAS
\end{tabular}

Quadro 5 - Número de entrevistas realizadas e analisadas 
Para a análise dos dados construídos ao longo da pesquisa, utilizamos diferentes procedimentos. Realizamos a discussão dos mesmos em dois tópicos: 3.4.1. Análise dos dados das visitas às instituições do município de Educação Infantil no campo; 3.4.2. Análise dos dados das visitas à Escola Flamboyant e às famílias do campo.

\subsubsection{Análise dos dados das visitas às instituições do município de Educação Infantil no campo}

Conforme indicado anteriormente, o material construído nas visitas às 13 instituições que ofereciam Educação Infantil no campo foi: 9 entrevistas - gravadas em áudio - e o diário de campo. No diário de campo, foram registradas 4 entrevistas realizadas com gestoras das instituições de Educação Infantil, bem como dados observados nas instituições e impressões pessoais.

Tais dados foram analisados qualitativamente e apresentados no presente trabalho para caracterizar os contextos nos quais a pesquisa foi realizada, a partir da descrição da Educação Infantil no campo do município A. Para a realização dessa análise, utilizamos os seguintes procedimentos:

1) Buscamos, no material construído, trechos nos quais eram discutidas as seguintes temáticas: localização e histórico da instituição; modalidade de atendimento e período de funcionamento; faixa etária e número de crianças atendidas; profissionais e sua formação; estrutura; transporte; famílias atendidas; demanda por vagas. Tais temáticas constituíam-se como itens do guia de entrevistas realizadas com as profissionais.

\section{Exemplo:}

Trecho de uma das entrevistas:

\{Pesquisadora: Como que as crianças vêm pra cá?

Entrevistada: Tudo de transporte. A Prefeitura oferece (...)

Temática:

Pesquisadora: E qual que é a distância máxima que você percebe, assim, que elas percorrem?

O transporte

Entrevistada: Ah!, é longe (...) Tem menino que fica quase uma hora e meia dentro da van...\}

2) Posteriormente, sistematizamos os dados de cada entrevista em quadros, para que pudéssemos visualizar todas as falas que se referiam às temáticas mencionadas. 
Para que fique mais clara para o leitor esta etapa da análise dos dados, apresentamos, abaixo, o modelo do quadro utilizado:

\begin{tabular}{|c|c|}
\hline Temas & Falas \\
\hline Localização e histórico da instituição & \\
\hline Modalidade de atendimento e período de funcionamento & \\
\hline Faixa etária e número de crianças atendidas & \\
\hline Profissionais e sua formação & \\
\hline Estrutura da instituição & \\
\hline Transporte & \\
\hline Famílias atendidas & \\
\hline Demanda por vagas & \\
\hline
\end{tabular}

3) Com a sistematização dos dados de cada entrevista no quadro acima apresentado, optamos por construir quadros relativos a cada temática e nos quais constavam os relatos das entrevistadas de todas as instituições, integrando, assim, as informações para composição de uma visão mais geral das instituições, dos contextos nos quais se situavam as Escolas rurais.

Exemplo:

Temática: O Transporte

\begin{tabular}{|c|l|}
\hline Instituição & Falas \\
\hline A & \\
\hline B & \\
\hline Etc. & \\
\hline
\end{tabular}

4) Após a sistematização dos dados de todas as instituições em "quadros temáticos", realizamos a apresentação dos mesmos de uma forma compilada. Tais dados são apresentados no capítulo 4. Contextos de realização da pesquisa e, mais especificamente, no item 4.2. A Educação Infantil no campo do município A.

\subsubsection{Análise dos dados das visitas à Escola Flamboyant e às famílias do campo}

Os dados construídos ao longo das visitas à Escola Flamboyant e às famílias do campo e registrados no diário de campo foram utilizados no presente trabalho para descrever os contextos investigados: a Escola Flamboyant e as famílias do campo. Para a análise do diário de campo, realizamos diversas leituras do mesmo, identificando os registros que se referiam a tais contextos. Tais dados serão apresentados no capítulo 4. Contextos de 
realização da pesquisa, mais especificamente nos itens 4.3. A Escola Flamboyant e 4.4. As famílias atendidas pela Escola Flamboyant e participantes da pesquisa.

Já os dados construídos nas entrevistas realizadas com profissionais e famílias da Escola Flamboyant foram utilizados na discussão da relação entre a Escola e as famílias do campo. Para a análise das entrevistas, utilizamos os seguintes procedimentos:

1) Realizamos diversas leituras do material buscando identificar temáticas sobre a relação entre a Educação Infantil e as famílias do campo e que foram discutidas pelas participantes do estudo. Após a realização dessas inúmeras leituras, evidenciamos/construímos os seguintes eixos temáticos e que direcionaram o tratamento do material:

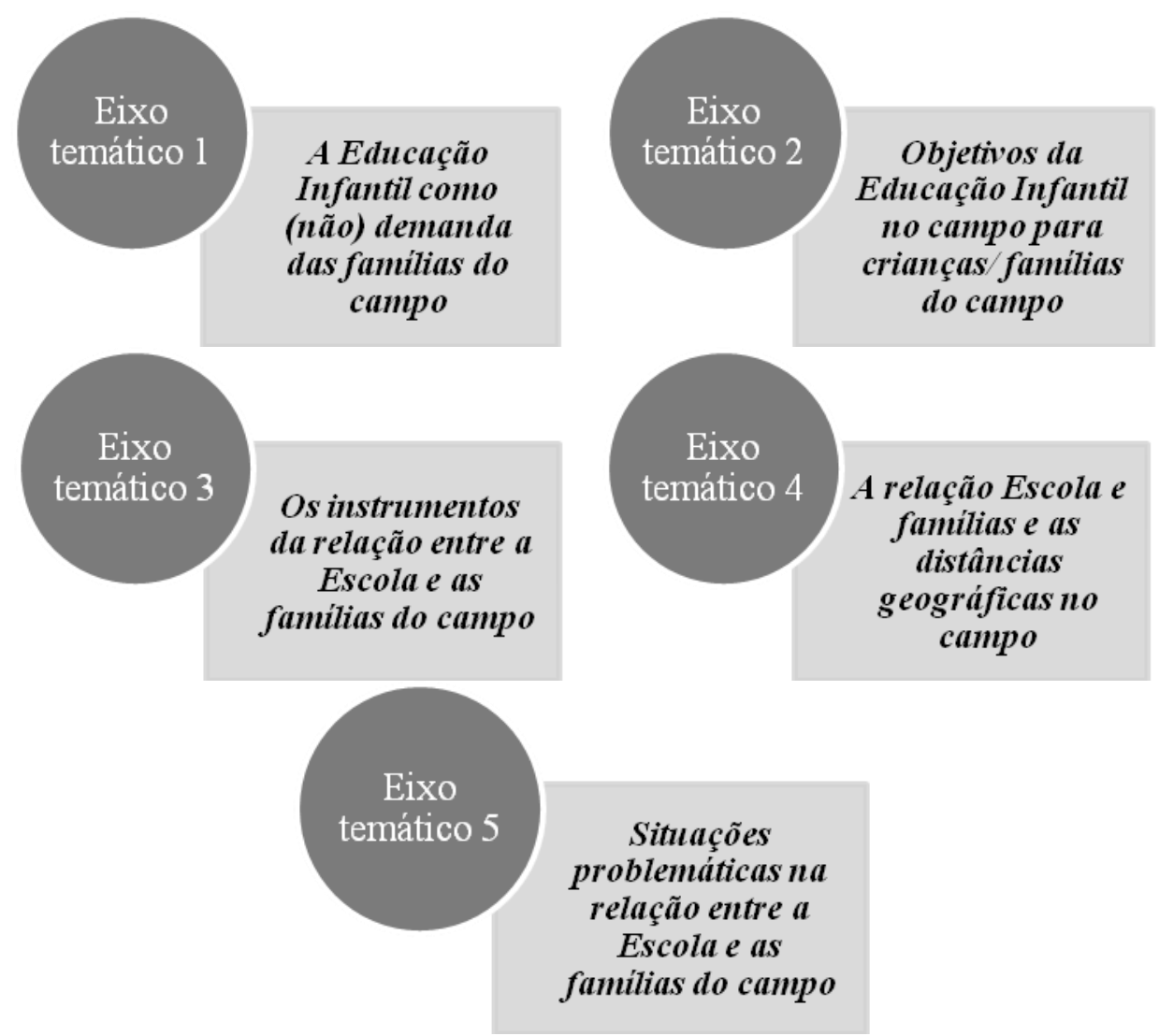

2) Após a identificação/definição dos eixos temáticos presentes no material, buscamos destacar, em cada entrevista (das profissionais e famílias), as significações e as falas das entrevistadas que se referiam a cada eixo temático. Para tanto, elaboramos quadros nos quais fomos registrando tais significações e falas, conforme exemplificado a seguir: 
Exemplo:

\section{Entrevista com Profissional 1}

Eixo temático 1: A Educação Infantil como (não) demanda das famílias do campo

\begin{tabular}{|c|c|}
\hline Significações & Falas \\
\hline $\mathbf{1}$ & \\
\hline $\mathbf{2}$ & \\
\hline Etc. & \\
\hline
\end{tabular}

3) Posteriormente, buscamos discutir as significações construídas pelas profissionais e famílias referentes à cada eixo temático. Tais dados são apresentados no capítulo 5. A relação entre a Escola Flamboyant e as famílias do campo. Neste capítulo, estruturamos subcapítulos e que se referem a cada eixo temático do trabalho, sendo os mesmos assim denominados: 5.1. A Educação Infantil como (não) demanda das famílias do campo; 5.2. Objetivos da Educação Infantil no campo para as crianças/famílias do campo; 5.3. Os instrumentos da relação entre a Escola Flamboyant e as famílias do campo; 5.4. A relação Escola e famílias e as distâncias geográficas no campo; 5.5. Situações problemáticas na relação entre a Escola Flamboyant e as famílias do campo.

Cada subcapítulo possui três itens distintos, sendo que:

- No primeiro item, discutimos as significações das profissionais referentes à temática;

- No segundo item, discutimos as significações das famílias sobre a temática;

- No terceiro item, buscamos discutir as aproximações e distanciamentos existentes entre as significações das profissionais e das famílias sobre o tema abordado no subcapítulo.

A partir da utilização dos procedimentos de análise dos dados da pesquisa citados acima, apresentamos a seguir o capítulo 3. Contextos de realização da pesquisa que contém dados construídos nas visitas às 13 instituições que ofereciam Educação Infantil no campo no município A, à Escola Flamboyant e às famílias do campo e que se referem e caracterizam os contextos investigados. Expomos, em seguida, o capítulo 4. A relação entre a Escola Flamboyant e as familias do campo que contém dados relativos às visitas à Escola Flamboyant e às famílias do campo atendidas por esta instituição e que se referem à relação entre as instituições escolar e familiar. 


\section{CAPÍTULO}

4

CONTEXTOS DE REALIZAÇÃO DA PESQUISA

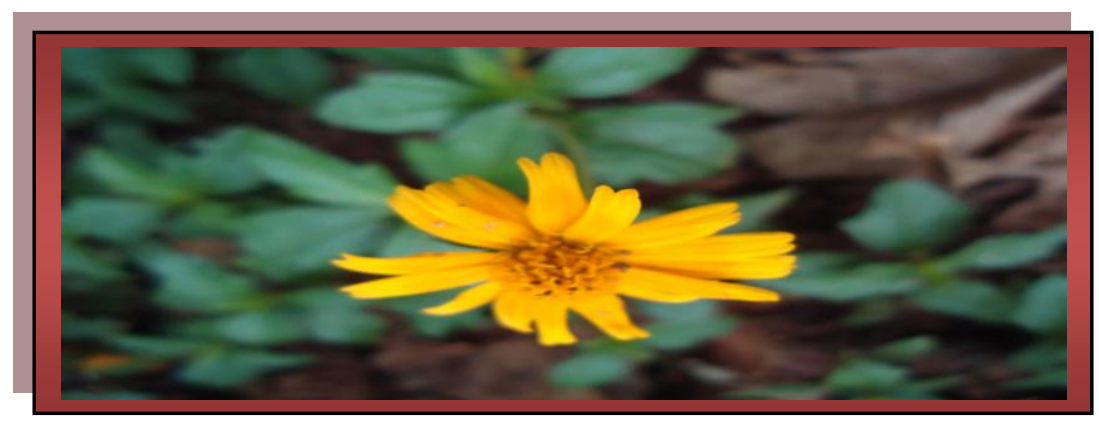





\section{CONTEXTOS DE REALIZAÇÃO DA PESQUISA}

No presente capítulo, realizamos a apresentação de dados dos contextos nos quais a pesquisa foi realizada. A apresentação dos mesmos foi sistematizada nos seguintes itens: 4.1. $O$ município A; 4.2. A Educação Infantil no campo do município A; 4.3. A Escola Flamboyant; 4.4. As famílias atendidas pela Escola Flamboyant e participantes da pesquisa.

\subsection{O município $A$}

O município A, segundo dados do IBGE (2010), possui uma economia voltada para a prestação de serviços e para a indústria, sendo a agropecuária o setor menos relevante da sua economia.

De acordo com dados do Censo 2010 (IBGE, 2011), o município A é de grande porte, sendo $97,2 \%$ de sua população da zona urbana e $2,8 \%$ da zona rural. No que se refere ao número de crianças, de acordo com a faixa etária, o Censo de 2010 apontou as seguintes proporções: $6,5 \%$ da população do município eram crianças de 0 a 4 anos e 6,8\% eram crianças de 5 a 9 anos. Ressaltamos que a forma como os dados são apresentados pelo IBGE dificulta a contagem da população-alvo da Educação Infantil (de 0 a 5 anos) e também não permite sabermos o número de crianças do campo e da cidade.

De acordo com dados da Secretaria de Educação, no município, havia, no ano de 2010, 115 instituições de Educação Infantil, sendo que 81 eram da Rede Direta (Municipais) e 34 da Rede Indireta (Organizações não governamentais - ONGs conveniadas com o município). A Rede Direta era composta por 56 EMEIs (Escolas Municipais de Educação Infantil) e 25 Escolas de Ensino Fundamental que possuíam salas de Educação Infantil. A Rede Indireta era formada por 34 ONGs, responsáveis pelo atendimento de crianças da Educação Infantil.

Nas 115 instituições de Educação Infantil, havia 17.500 crianças matriculadas, sendo que, destas, 14.500 estavam na Rede Direta e 3.000 estavam na Rede Indireta.

No que se refere às instituições de Educação Infantil do campo do município, existiam, em 2010, 3 instituições da Rede Indireta, ou seja, ONGs, que atendiam especificamente crianças de 0 a 5 anos (EEEICs) ${ }^{9}$. No campo do município havia ainda 10 instituições da Rede Direta e que eram Escolas do Ensino Fundamental com salas de

\footnotetext{
${ }^{9}$ Iremos utilizar, neste estudo, a sigla EEEICs para nos referir às Escolas Exclusivas de Educação Infantil no campo no município.
} 
Educação Infantil (EEFEICs) ${ }^{\mathbf{1 0}}$. Vale enfatizarmos que havia, no município, 50 Escolas de Ensino Fundamental, sendo que destas 37 se localizavam na cidade e 13 se localizavam no campo. Das 37 Escolas da cidade, 15 possuíam salas de Educação Infantil, e das 13 Escolas do campo, 10 atendiam à Educação Infantil.

De acordo com dados das gestoras das instituições, havia 207 crianças de 4 elou 5 anos matriculadas nas EEFEICs, e 167 de 0 a 5 anos matriculadas nas EEEICs. Ao todo, tínhamos 374 crianças matriculadas na Educação Infantil no campo, o que correspondia a $\mathbf{2 , 1 \%}$ da população de crianças matriculadas na Educação Infantil do município ( $\mathrm{n}=17.500)$, no ano pesquisado.

Abaixo apresentamos quadros que sistematizam as informações acima, sendo que o Quadro 6 apresenta dados relativos às instituições de Educação Infantil da cidade e o Quadro 7 dados referentes às instituições que ofereciam Educação Infantil no campo.

\begin{tabular}{|c|c|c|c|c|}
\hline \multirow{2}{*}{$\begin{array}{l}\text { Tipo de instituições } \\
N^{o} \text { de instituições } \\
\text { e criancas }\end{array}$} & \multicolumn{2}{|c|}{ Instituições da Rede Direta } & \multirow{2}{*}{$\begin{array}{c}\text { Instituições da } \\
\text { Rede Indireta } \\
\text { Escolas Exclusivas } \\
\text { de Educação } \\
\text { Infantil }\end{array}$} & \multirow[t]{2}{*}{ Total } \\
\hline & $\begin{array}{l}\text { Escolas de Ensino } \\
\text { Fundamental com } \\
\text { sala(s) de } \\
\text { Educação Infantil }\end{array}$ & EMEIs & & \\
\hline $\mathrm{N}^{0}$ de instituições & 15 & 56 & 31 & 102 \\
\hline $\begin{array}{l}\mathrm{N}^{0} \text { de crianças } \\
\text { matriculadas }\end{array}$ & \multicolumn{2}{|l|}{14293} & 2833 & 17126 \\
\hline
\end{tabular}

Quadro 6 - Instituições de Educação Infantil da cidade no município, no ano de 2010

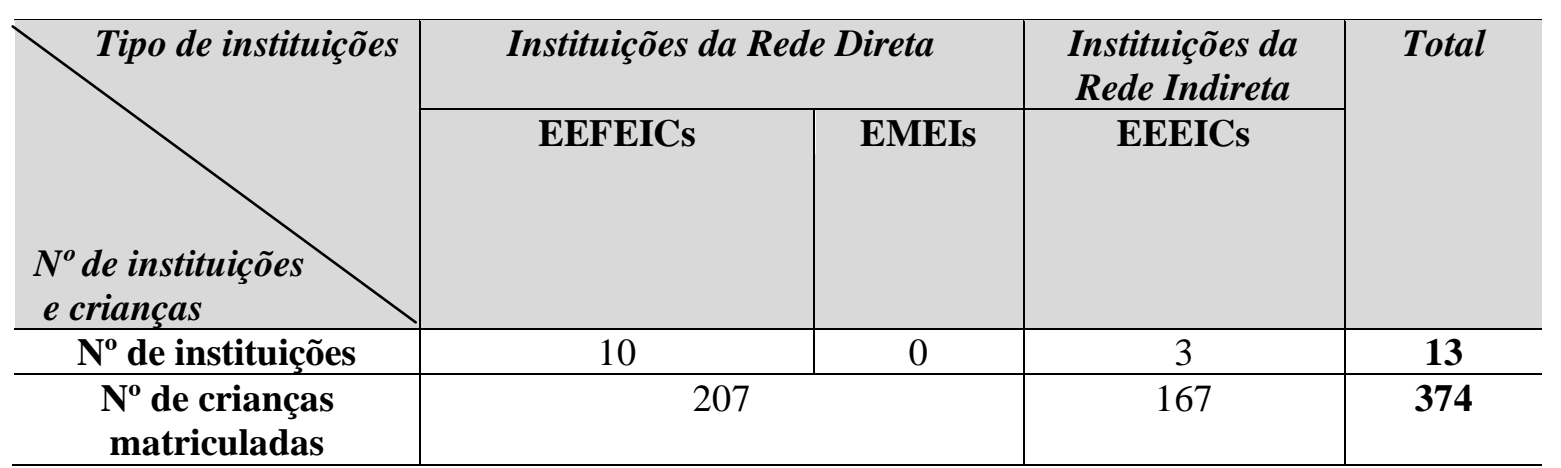

Quadro 7 - Instituições de Educação Infantil do campo no município, no ano de 2010

A classificação das instituições pesquisadas, tanto da rede direta como da indireta, como sendo instituições de educação do campo foi realizada pelo município. Dessa forma,

\footnotetext{
${ }^{10}$ Iremos utilizar, no presente trabalho, a sigla EEFEICs para nos referir às Escolas de Ensino Fundamental no campo do município e que ofereciam Educação Infantil.
} 
consideramos tais instituições como sendo rurais, no presente trabalho, com base na classificação anteriormente realizada pelo município A.

\subsection{A Educação Infantil no campo do município $A$}

A ida às Escolas do campo do município A que ofereciam Educação Infantil permitiu construirmos dados sobre tais contextos de atendimento de crianças e de famílias rurais no município. Optamos por apresentar os dados das EEEICs e das EEFEICs separadamente. Por isso, apresentamos a seguir, no item 4.2.1, dados da Educação Infantil ofertada em EEEICs e, no item 4.2.2., dados da Educação Infantil ofertada em EEFEICs.

No presente trabalho, iremos chamar as EEEICs de instituições: A, B e C. Iremos nos referir às EEFEICs como instituições: D, E, F, G, H, I, J, L, M e N.

\subsubsection{A Educação Infantil ofertada em EEEICs}

No município A, a Educação Infantil era oferecida em instituições voltadas para o atendimento de crianças de 0 a 5 anos, caracterizando-se como Creches/Pré-escolas. As EEEICs no município eram 3 ONGs, conveniadas com a Prefeitura, e que foram fundadas nas décadas de 1990 e de 2000.

Tais instituições de Educação Infantil funcionavam em prédios cuja estrutura contava com: refeitório, cozinha, banheiros, salas e área externa. Duas tinham, além disso, uma sala de recepção, parque infantil e acesso à internet. De forma geral, não possuíam recursos audiovisuais.

Para que o leitor possa melhor conhecê-las, apresentamos abaixo o Quadro 8 que nos informa sobre a localização das instituições e características do atendimento oferecido. 


\begin{tabular}{|c|c|c|c|}
\hline$\underset{\text { DADOS }}{\text { INSTITUIÇÃO }}$ & $A$ & $\boldsymbol{B}$ & $C$ \\
\hline Localização & Distrito. & Distrito. & $\begin{array}{l}\text { Setor de chácaras } \\
\text { localizado ao lado de } \\
\text { bairros da cidade. }\end{array}$ \\
\hline $\begin{array}{l}\text { Idade das } \\
\text { crianças } \\
\text { atendidas }\end{array}$ & 6 meses a 5 anos & 1 a 5 anos & 4 meses a 5 anos \\
\hline $\begin{array}{c}\text { Período de } \\
\text { atendimento }\end{array}$ & $\begin{array}{l}\text { Manhã (crianças de } 0 \text { a } 5 \\
\text { anos) } \\
\text { Tarde (crianças de } 0 \text { a } 3 \\
\text { anos) }\end{array}$ & $\begin{array}{l}\text { Manhã (crianças de } 1 \text { a } 4 \\
\text { anos) } \\
\text { Tarde (crianças de } 1 \text { a } 5 \\
\text { anos e } 11 \text { meses) }\end{array}$ & Integral \\
\hline Número de salas & 2 & $\begin{array}{c}2 \text { (3 estavam sendo } \\
\text { construídas) }\end{array}$ & 4 \\
\hline $\begin{array}{l}\text { Número de } \\
\text { crianças }\end{array}$ & 25 & 34 & 108 \\
\hline $\begin{array}{l}\text { Número de } \\
\text { profissionais }\end{array}$ & 5 & 6 & 14 \\
\hline
\end{tabular}

Quadro 8 - Caracterização das EEEICs

De acordo com o quadro acima, podemos perceber que as EEEICs se localizavam em distritos e setor de chácara, locais onde residiam aglomerados de famílias próximas às instituições. O número de crianças atendidas variava de 25 a 108.

No que tange ao período de atendimento, notamos que, na instituição $\mathrm{A}$, o atendimento era oferecido em tempo integral para as crianças de 0 a 3 anos. Já as crianças de 4 a 5 anos frequentavam a instituição A no período da manhã e uma EEFEIC no período da tarde. $\mathrm{Na}$ instituição B, o atendimento era integral para as crianças de 0 a 4 anos. Já as crianças de 5 anos iam para uma EEFEIC no período da manhã e para a instituição B no período da tarde. $\mathrm{Na}$ instituição $\mathrm{C}$, o atendimento era integral para as crianças de 0 a 5 anos.

Em relação ao número de profissionais existentes nas instituições, percebemos que o mesmo variava de 5 a 14. A maioria dos profissionais das instituições - $\mathbf{8 8 \%}$ - residia na cidade. Ressaltamos que na instituição $\mathrm{C}$ havia professores e educadores, sendo os primeiros com formação superior e os segundos com nível médio. Já as outras duas instituições contavam apenas com educadores.

Nas instituições A e B, não era disponibilizado transporte escolar para os profissionais e para as crianças, sendo o mesmo oferecido apenas para profissionais e crianças da instituição C. O fato de não haver o transporte, de acordo com uma das profissionais, impossibilitava famílias que moravam em fazendas - e que não possuíam meios de trazer a criança para a instituição - de serem atendidas. 
Em relação às famílias atendidas pelas EEEICs, entrevistadas deram informações sobre a ocupação das mesmas apresentadas no quadro a seguir.

\begin{tabular}{|c|c|}
\hline INSTITUIÇÃO & OCUPAÇÃO DAS FAMÍLIAS \\
\hline $\mathbf{A}$ & Funcionários de fazendas; domésticas. \\
\hline B & Funcionários de indústrias e de fazendas; domésticas; profissionais do lar. \\
\hline $\mathbf{C}$ & $\begin{array}{l}\text { Donas de casa; faxineiras; diaristas; serventes; carroceiros; pedreiros; auxiliar de } \\
\text { produção. }\end{array}$ \\
\hline
\end{tabular}

Quadro 9 - Ocupação das famílias atendidas pelas EEEICs

Percebemos que as famílias atendidas possuíam ocupações diversificadas. Os trabalhos das famílias eram realizados tanto no campo (agricultura, pecuária), como na cidade (construção, carretos, serviços domésticos). A maioria das famílias atendidas pelas instituições A e B era moradora dos distritos, e da instituição C eram moradoras do setor de chácaras.

No que se refere à relação dessas famílias com a Educação Infantil, um dado investigado foi se havia a existência de demanda por Educação Infantil no campo. Sobre esta temática, profissionais das 3 EEEICs afirmaram que havia, nas instituições, demanda da comunidade por vagas na Educação Infantil, o que indicou a existência de solicitação de famílias pela ampliação do atendimento oferecido no campo em Creches e Pré-escolas.

\subsubsection{A Educação Infantil ofertada em EEFEICs}

As instituições de EEFEICs eram municipais e compunham o que se denominava de "instituições da rede direta" do município. As EEFEICs foram fundadas em períodos diversos e que nos remetem às décadas de 1920, 1940, 1950, 1960, 1980 e 1990. Algumas das instituições investigadas iniciaram suas atividades com salas multisseriadas e continham poucos alunos. Porém, estas instituições passaram pelo processo de nucleação, recebendo alunos de outras regiões e tornando-se instituições com um número maior de crianças e com salas seriadas.

No que tange ao atendimento à Educação Infantil, as gestoras não souberam ao certo quando o mesmo começou. Nas instituições que já tiveram salas multisseriadas, algumas profissionais disseram que achavam que, na época de existência destas salas, as Escolas já recebiam as crianças da Educação Infantil, mas não tiveram informações precisas sobre esta questão. Nas instituições em que houve o relato do ano de implementação da Educação Infantil, constatamos que o atendimento iniciou-se após 2005. 
Para que o leitor possa compreender como eram as instituições pesquisadas, na época do estudo, apresentamos a seguir o Quadro 10 que contém informações que as caracterizam.

\begin{tabular}{|c|c|c|c|c|c|c|}
\hline ESCOLA & LOCALIZAÇÃO & MODALIDADE & PERÍODO & $\begin{array}{c}N^{o} \\
\text { PROFIS. }\end{array}$ & $\begin{array}{c}N^{o} \\
\text { ALUNOS }\end{array}$ & $\begin{array}{c}N^{o} \\
\text { SALAS }\end{array}$ \\
\hline $\mathbf{D}$ & $\begin{array}{l}\text { A Escola situava-se em uma região cercada } \\
\text { por fazendas, acampamentos, assentamentos e } \\
\text { indústrias. }\end{array}$ & $\begin{array}{c}\text { EI (5 anos) ao } \\
9^{\circ} \text { ano }\end{array}$ & $\mathrm{Me} \mathrm{T}$ & 68 & 500 & 15 \\
\hline $\mathbf{E}$ & $\begin{array}{c}\text { A Escola localizava-se em uma fazenda } \\
\text { particular com plantações de eucaliptos onde } \\
\text { funcionava uma indústria de corte de árvores. } \\
\text { Nesta fazenda, havia uma colônia de } \\
\text { moradores/trabalhadores, bem próxima à } \\
\text { Escola. }\end{array}$ & $\begin{array}{l}\text { EI (4 e } 5 \text { anos) } \\
\quad \text { ao } 9^{\circ} \text { ano }\end{array}$ & M e T & 27 & 168 & 8 \\
\hline $\mathbf{F}$ & $\begin{array}{c}\text { A EEFEIC funcionava em uma Escola } \\
\text { agrotécnica de uma Universidade Federal (em } \\
\text { prédios separados) e que possuía uma colônia } \\
\text { de moradores/trabalhadores da Escola } \\
\text { agrotécnica. }\end{array}$ & $\begin{array}{c}\text { EI (5 anos) ao } \\
9^{\circ} \text { ano }\end{array}$ & $\mathrm{Me} \mathrm{T}$ & 46 & 300 & 7 \\
\hline $\mathbf{G}$ & $\begin{array}{l}\text { A instituição escolar localizava-se em uma } \\
\text { região cercada por fazendas, acampamentos, } \\
\text { assentamentos e indústrias. }\end{array}$ & $\begin{array}{c}\text { EI (5 anos) ao } \\
9^{\circ} \text { ano }\end{array}$ & $\mathrm{TeN}$ & 35 & 240 & 8 \\
\hline $\mathbf{H}$ & $\begin{array}{l}\text { A Escola localizava-se em uma região cercada } \\
\text { por fazendas e indústrias, estando bem } \\
\text { próxima a uma vila da cidade. }\end{array}$ & $\begin{array}{c}\text { EI (5 anos) ao } \\
9^{\circ} \text { ano }\end{array}$ & $\mathrm{M}$ & 33 & 223 & 13 \\
\hline I & $\begin{array}{l}\text { A Escola situava-se em uma região cercada } \\
\text { por fazendas, acampamentos, assentamentos e } \\
\text { indústrias. }\end{array}$ & $\begin{array}{c}\text { EI (5 anos) ao } \\
9^{\circ} \text { ano }\end{array}$ & M & 45 & 280 & 12 \\
\hline $\mathbf{J}$ & A Escola localizava-se em um distrito. & $\begin{array}{c}\text { EI (5 anos) ao } \\
9^{\circ} \text { ano }\end{array}$ & $\mathrm{Me} \mathrm{T}$ & 22 & 80 & 6 \\
\hline $\mathbf{L}$ & A Escola localizava-se em um distrito. & $\begin{array}{c}\text { EI (4 e } 5 \text { anos }) \\
\text { ao } 9^{\circ} \text { ano } \\
\end{array}$ & $\mathrm{Me} \mathrm{T}$ & 32 & 130 & 7 \\
\hline M & A Escola localizava-se em um distrito. & $\begin{array}{c}\text { EI (5 anos) ao } \\
9^{\circ} \text { ano }\end{array}$ & M & 72 & 600 & 22 \\
\hline $\mathbf{N}$ & A Escola localizava-se em um distrito. & $\begin{array}{l}\text { EI (4 e } 5 \text { anos }) \\
\text { ao Ensino } \\
\text { Médio } \\
\end{array}$ & $\mathrm{Me} \mathrm{T}$ & 31 & 131 & 10 \\
\hline
\end{tabular}

Quadro 10 - Caracterização das EEFEICs

Percebemos, no quadro acima, que as EEFEICs, no município A, localizavam-se em regiões com características distintas. É importante ressaltarmos que tais "localizações" se referem às regiões mais próximas das instituições, sendo que as Escolas atendiam regiões também mais distantes.

No Quadro 10, notamos ainda que outro aspecto que diferenciava as Escolas era o número de alunos atendidos, que variava de 80 a 600 , bem como de profissionais existentes, que ia de 22 a 72. A maioria destes profissionais - 93\% - residia na cidade.

No que tange à modalidade de educação oferecida nas EEFEICs, quase a totalidade - 9 Escolas - atendia da Educação Infantil ao Ensino Fundamental, sendo que apenas 1 Escola atendia da Educação Infantil ao Ensino Médio. 
As Escolas pesquisadas funcionavam, geralmente, em prédios com um mesmo padrão de estrutura, inclusive semelhante às da zona urbana do município, e que incluía: salas de aula, sala de professores, secretaria, refeitório, laboratório de informática, quadra esportiva, cozinha, depósitos, pátio, banheiros, "barzinho"11. As instituições possuíam ainda equipamentos como data-show, xerox, máquina fotográfica, aparelho de som e filmadora. Em 7 Escolas havia internet, 4 tinham parque infantil, 1 tinha piscina e 2 tinham horta.

A Educação Infantil nas EEFEICs funcionava com a abertura de uma ou duas salas de crianças de 4 e/ou 5 anos. No ano e período de realização da presente pesquisa existiam, nas 10 instituições pesquisadas, 12 salas de Educação Infantil em funcionamento.

O Quadro a seguir contém características gerais sobre o atendimento existente das crianças de 4 e/ou 5 anos nas EEFEICs, a saber: número de salas de Educação Infantil e idades das crianças atendidas; período de atendimento e número de crianças matriculadas nas instituições escolares.

\begin{tabular}{|c|c|c|c|}
\hline INSTITUIÇÃO & $\begin{array}{c}\text { NÚMERO DE } \\
\text { SALAS/IDADES DAS } \\
\text { CRIANCSAS }\end{array}$ & $\begin{array}{c}\text { PERÍODO DE } \\
\text { ATENDIMENTO }\end{array}$ & $\begin{array}{l}\text { NÚMERO DE } \\
\text { CRIANÇAS }\end{array}$ \\
\hline $\mathbf{A}$ & 1 sala de 5 anos & Tarde & 24 \\
\hline B & $\begin{array}{c}2 \text { salas }(1 \mathrm{de} 4 \text { anos e } 1 \text { de } 5 \\
\text { anos) }\end{array}$ & Manhã & $\begin{array}{c}22 \text { (7 na sala de } 4 \\
\text { anos e } 15 \text { na sala de } \\
5 \text { anos })\end{array}$ \\
\hline $\mathbf{C}$ & 1 sala de 5 anos & Manhã & 15 \\
\hline D & 1 sala de 5 anos & Tarde & 16 \\
\hline $\mathbf{E}$ & 1 sala de 5 anos & Manhã & 11 \\
\hline $\mathbf{F}$ & 1 sala de 5 anos & Manhã & 24 \\
\hline $\mathbf{G}$ & 1 sala de 5 anos & Tarde & 14 \\
\hline $\mathbf{H}$ & 1 sala de 4 e 5 anos & Tarde & 15 \\
\hline $\mathbf{I}$ & 2 salas de 5 anos & Manhã & $\begin{array}{c}48 \text { (1 sala com } 23 \text { e } 1 \\
\text { sala com } 25)\end{array}$ \\
\hline $\mathbf{J}$ & 1 sala de 4 e 5 anos & Tarde & 18 \\
\hline
\end{tabular}

Quadro 11 - Dados sobre a Educação Infantil nas EEFEICs

Percebemos, a partir da análise das informações do Quadro 11, que a maioria das instituições, 7 Escolas, atendia na(s) sala(s) de Educação Infantil somente crianças de 5 anos, sendo que apenas 3 Escolas recebiam crianças de 4 a 5 anos. O atendimento, em todas as

\footnotetext{
${ }^{11}$ Local onde a Escola comercializava alimentos (por exemplo, bolos e salgados assados) e bebidas (sucos), que eram sugeridos e permitidos por nutricionistas que trabalhavam para o município. O termo "barzinho", para se referir a esta parte da Escola, era utilizado no cotidiano da instituição, sendo mantido no presente trabalho.
} 
instituições, era oferecido em período parcial. Notamos ainda que o número de crianças atendidas variava de 11 a 48 .

O quadro apresentado nos aponta ainda que, na maioria das instituições $(n=8)$, os agrupamentos de crianças da Educação Infantil eram compostos por crianças da mesma idade. Em 2 instituições, que atendia crianças de 4 a 5 anos, houve a formação de uma única sala com crianças da Educação Infantil de diferentes idades. Não havia, nas Escolas, o agrupamento de crianças da Educação Infantil com as crianças do Ensino Fundamental.

As crianças de 4 e 5 anos, nas EEFEICs, tinham diversos professores, sendo um regente e vários professores de áreas específicas, tais como de Educação Física, Artes, Informática, Ensino Religioso e Literatura. A maioria dos professores das EEFEICs tinha nível superior e especialização e, conforme mencionado anteriormente, residia na cidade.

O transporte era oferecido gratuitamente, pelo município, aos profissionais e, também, às crianças que eram buscadas e deixadas em suas residências, sendo proibido o uso do mesmo por outras pessoas como, por exemplo, familiares das crianças matriculadas. Sobre os veículos utilizados para o transporte dos profissionais constatamos que os mesmos eram vans e das crianças eram vans elou ônibus. O serviço era oferecido por uma empresa terceirizada, contratada pela Prefeitura. O tempo que as crianças ficavam no interior dos veículos para irem para a Escola variava de $\mathbf{3 0}$ minutos a 2 horas. O tempo total (ida e volta) que permaneciam no transporte na jornada diária variava de 1 hora a 4 horas. O longo período dentro da van ocorria devido à distância e à forma de transporte, que ia pegando e levando as crianças em grupo, o que fazia com que algumas permanecessem mais tempo no veículo, pois tinham que esperar o motorista percorrer as residências das outras crianças. Não havia nas vans e ônibus monitores para acompanharem as crianças, sendo o motorista o único adulto presente nesses veículos.

No que tange às famílias atendidas nas instituições escolares, as entrevistadas mencionaram que as mesmas eram envolvidas com diferentes atividades profissionais, descritas no quadro a seguir. 


\begin{tabular}{|c|c|}
\hline ESCOLA & OCUPAÇ̃̃ DAS FAMÍLIAS \\
\hline $\mathbf{A}$ & $\begin{array}{l}\text { Fazendeiros; Funcionários de fazendas; Trabalhadores em indústrias; Acampados e } \\
\text { Assentados da reforma agrária. }\end{array}$ \\
\hline $\mathbf{B}$ & Trabalhadores em indústrias; Funcionários de fazendas. \\
\hline $\mathbf{C}$ & Funcionários de uma Escola agrotécnica; Funcionários de fazendas. \\
\hline $\mathbf{D}$ & $\begin{array}{c}\text { Fazendeiros; Funcionários de fazendas; Trabalhadores em indústrias; Assentados da } \\
\text { reforma agrária. }\end{array}$ \\
\hline $\mathbf{E}$ & Funcionários de fazendas; Trabalhadores em uma vila próxima à Escola e na cidade. \\
\hline $\mathbf{F}$ & Trabalhadores em indústrias; Trabalhadores na cidade; Assentados da reforma agrária. \\
\hline $\mathbf{G}$ & Trabalhadores no distrito; Funcionários de fazendas; Assentados da reforma agrária. \\
\hline $\mathbf{H}$ & $\begin{array}{l}\text { Trabalhadores no distrito e na cidade; Trabalhadores em indústrias; Funcionários de } \\
\text { fazendas. }\end{array}$ \\
\hline I & Funcionários de fazendas; Trabalhadores em indústrias; Fazendeiros. \\
\hline $\mathbf{J}$ & Trabalhadores no distrito e na cidade; Funcionários das fazendas. \\
\hline
\end{tabular}

Quadro 12 - Ocupação das famílias atendidas pelas EEFEICs

Os funcionários de fazendas podiam estar envolvidos em diferentes atividades ligadas à agricultura (plantio, colheita) e/ou à pecuária (ordenhador de vacas, "peão"). No que se refere às indústrias, nas quais algumas famílias trabalhavam, destacamos que estas podiam ser granjas (porcos ou aves), frigoríficos, pedreiras, produtoras de sementes e empresas de corte de árvores e de reflorestamento. As famílias atendidas pelas EEFEICs moravam em diferentes locais, tais como: acampamentos, assentamentos, fazendas, colônias, vilas e distritos.

As famílias do campo, de acordo com 9 das 10 Escolas investigadas, solicitavam atendimento de crianças da Educação Infantil, sendo maior a procura pelo atendimento de crianças abaixo dos 4 anos. Um fator importante a ser considerado é que o atendimento das crianças de 5 anos ocorria em todas as EEFEICs.

A Escola Flamboyant, na qual desenvolvemos a investigação sobre a relação da Escola no campo e famílias do campo, era uma das EEFEICs. Dados mais detalhados sobre esta instituição são apresentados no próximo item. 


\subsection{A Escola Flamboyant ${ }^{12}$}

A Escola Flamboyant era uma instituição municipal, fundada na década de 1990, localizada próxima a uma rodovia do município $A$ e em uma região cercada por assentamentos, acampamentos, fazendas e agroindústrias.

A Escola atendia cerca de 500 crianças/adolescentes, sendo oferecidas vagas da Educação Infantil ao Ensino Fundamental. No que tange à Educação Infantil a mesma possuía, em 2010, uma sala composta por 24 crianças de 5 anos.

A Escola atendia as crianças de segunda-feira a sexta-feira, com exceção dos feriados e períodos de recesso. A Escola cumpria, anualmente, 200 dias letivos. O horário de funcionamento da Escola era de 7h00min às 17h00min.

No que se refere à sua estrutura física, a Escola possuía energia elétrica, sistema de esgoto e água encanada. A instituição contava ainda com: sala da direção, sala de coordenação, sala dos professores, sala de vídeo, salas de aula, secretaria, laboratório de informática, laboratório de ciências, biblioteca, quadra de esporte coberta, parque infantil, piscina, cozinha, refeitório, banheiros e depósito. As salas da Escola Flamboyant eram agrupadas e localizadas em prédios distintos e, às vezes, distantes uns dos outros. Além desta estrutura física, a Escola contava ainda com alguns recursos digitais e audiovisuais como internet, máquina fotográfica, data-show, som e filmadora.

Para a realização de suas atividades, a Escola possuía 68 profissionais, sendo os mesmos: diretora, vice-diretoras, orientadoras, supervisora, professores, auxiliares de serviços gerais e profissionais da administração. A maioria dos professores da Escola possuía nível superior e pós-graduação. No que tange à Educação Infantil, a Escola contava com 6 professores, a saber: 1 regente $^{13}, 1$ de Informática, 1 de Artes, 1 de Educação Física, 1 de Recreação e 1 de Literatura. Todos estes profissionais residiam na cidade.

O município oferecia aos profissionais da Escola Flamboyant, bem como das outras EEFEICs, transporte para irem e voltarem de suas residências, conforme já discutido no item anterior. O transporte era oferecido ainda para todas as crianças atendidas pela instituição escolar.

\footnotetext{
${ }^{12}$ Por questões éticas, optamos por não apresentar algumas informações da Escola Flamboyant, a saber: dados históricos e da localização da instituição escolar, dados profissionais e pessoais das profissionais.

${ }^{13}$ O termo "regente" era utilizado na Escola para se referir ao professor que ficava maior tempo com as crianças da Educação Infantil. O mesmo se diferenciava dos demais professores da Educação Infantil, que eram de áreas específicas (Exemplo: Informática) pelo tempo de permanência na sala e, ainda, pelo fato de ter a possibilidade de trabalhar temáticas gerais com as crianças e não conteúdos específicos como os demais.
} 
O transporte das crianças da Escola Flamboyant era feito por vans e ônibus. As vans realizavam o transporte das crianças que moravam em locais cujas estradas eram mais estreitas e de difícil acesso para veículos maiores, enquanto os ônibus eram utilizados para irem aos locais de mais fácil acesso. O tempo que os veículos utilizavam para buscar as crianças variava de 1 hora a 2 horas (desde a saída da Escola até a volta à instituição) já que os percursos eram distintos para cada veículo. Os percursos percorridos pelas vans e ônibus eram compostos por estradas de terra e também por trechos da rodovia (próxima à Escola Flamboyant). Tal rodovia era asfaltada e possuía intenso fluxo de carros, caminhões e outros veículos.

No que tange às famílias atendidas pela Escola, verificamos que a maioria era de camada popular, sendo assentados, acampados, funcionários de fazendas e de indústrias da região. Algumas poucas famílias eram proprietárias das terras onde residiam.

A seguir, apresentamos dados mais detalhados sobre famílias atendidas pela Escola Flamboyant e que participaram do presente trabalho.

\subsection{As famílias atendidas pela Escola Flamboyant e participantes da pesquisa}

A apresentação dos dados das famílias que participaram do estudo será realizada em itens separados, a saber: 4.4.1. A família de Artur; 4.4.2.. A família de Iago; 4.4.3. A família de Íris; 4.4.4. A família de Flávio; 4.4.5. A família de Fabrício.

\subsubsection{A família de Artur}

A família de Artur era composta por sua mãe (Adriana), seu pai (Adriano) e sua irmã (Alice) que tinha 10 anos e que também estudava na Escola Flamboyant. Todos residiam em uma casa localizada em um lote de assentamento rural comprados por Adriano em sociedade com um parente. A casa era grande e com uma boa estrutura.

Adriana era natural de outro Estado e estava no município $A$ há 12 anos. Adriano era natural do município A. A família mudara da cidade para o campo havia uns 4 meses, considerando a época da realização da pesquisa. Adriano trabalhava viajando como motorista em uma Empresa de transporte e Adriana trabalhava em casa. Adriana, quando residia na cidade, trabalhava como empregada doméstica. A família tinha um veículo próprio, mas que era dirigido apenas por Adriano, quando o mesmo estava em casa. 
Obtive informações sobre o local de residência da família de Artur em uma das minhas idas aleatórias no transporte escolar, para buscar as crianças. Posteriormente, fui até a casa de Artur duas vezes. Na primeira, não achei ninguém em casa e, na segunda, encontrei com Adriana e Adriano. Expliquei então o motivo de minha ida e os objetivos da pesquisa. Adriano estava trabalhando em uma reforma na sua casa e logo teve que sair. Convidei então Adriana para participar da pesquisa e ela se prontificou a contribuir com a mesma.

Ao longo da pesquisa, Adriana foi simpática e pareceu bem à vontade para dar seus relatos e opiniões.

\subsubsection{A família de Iago}

A família de Iago era composta por sua mãe (Inês) e pai (Inácio). Iago tinha ainda mais duas irmãs, por parte de mãe, resultado da primeira união de Inês. A união de Inês com Inácio constitui-se como seu segundo casamento.

Junto com Iago moravam seus pais, uma irmã (por parte de mãe) e uma sobrinha (filha desta irmã). Todos residiam em uma casa da Indústria onde o pai de Inácio trabalhava e que se localizava ao lado de outras três casas, também pertencentes à Indústria e nas quais residiam três famílias distintas e empregadas na referida Indústria. A casa de Iago era pequena, porém tinha uma estrutura nova. A família de Iago não tinha veículo próprio.

Os pais de Iago eram naturais de cidades da região e haviam se mudado para o município $A$ há mais de 6 anos e para o local onde residiam há uns 2 anos. Conforme mencionamos, Inácio trabalhava como funcionário de uma grande Indústria na zona rural (Granja de porcos), já Inês trabalhava em casa e realizava serviços para outras famílias da região, como passar e lavar roupas. Inês ainda cuidava de outras crianças da comunidade a pedido dos pais destas, que trabalhavam no âmbito extradoméstico e que pagavam a Inês por este serviço. Inês relatou que cuidava de crianças de diferentes faixas etárias, desde bebês até crianças do Ensino Fundamental e que já chegara a ficar com cinco crianças em sua residência. Inês afirmou ainda que, em tempos anteriores, já trabalhara como auxiliar de Enfermagem, em uma cidade do interior, na época que não exigiam curso técnico.

Meu primeiro contato com a família de Iago foi em uma das idas que realizei, na van escolar, para buscar as crianças. Neste dia, vi a mãe de Iago, porém não foi possível conversar com a mesma, pois o transporte da Escola tinha de cumprir seu horário. Posteriormente, retornei de carro até sua residência. Ao chegar, encontrei-a em casa, bem como o pai de Iago. Expliquei o objetivo da pesquisa aos mesmos e convidei-os para participarem do estudo. Os 
dois aceitaram prontamente, porém Inácio explicou que tinha um compromisso (iria à Escola Flamboyant, a pedido da instituição) e que, por isso, poderia ter apenas uma pequena participação.

Senti que ambos estavam ansiosos para falar da Escola e para obter informações sobre a mesma. Porém, já no início da entrevista, ao apresentar os Termos de Consentimento, expliquei que, por questões éticas, não poderia dar informações sobre o que observara na Escola, sendo que o contrário também não ocorreria. Inês demonstrou frustração pelo fato de não dizer sobre como seu filho estava na Escola, sobre como era a relação deste com os profissionais e colegas, e sobre minha opinião a respeito da Educação Infantil na Escola. Porém, ao longo da entrevista, Inês demonstrou muita simpatia e entusiasmo em conversar sobre a temática da pesquisa. Inácio, conforme avisara anteriormente, participou apenas do início da entrevista.

\subsubsection{A família de Íris}

A família de Íris era composta pela mãe (Irene), pai (Irineu) e dois irmãos, um de 8 anos e outro de 13 anos, e que também estudavam na Escola Flamboyant.

Todos residiam em uma das casas pertencente à Indústria (Granja de porcos) onde o pai de Íris trabalhava. A família de Íris era vizinha da família de Iago e a casa de Íris também era pequena e com boa estrutura. A família de Íris tinha carro próprio.

Irineu trabalhava durante o dia na Indústria rural e fazia Faculdade, na cidade, no período noturno. Já Irene trabalhava em sua residência, realizando serviços domésticos.

Irene era natural de outro Estado, porém, de acordo com sua fala, mudou para o município $A$ em busca de melhores condições de vida. Os mesmos moram no campo do município há mais de 15 anos. Anteriormente ela trabalhava na Empresa, junto com o marido, porém, afirmou que abandonou o serviço para cuidar dos filhos.

Os encontros com a família de Íris ocorreram da mesma forma e nos mesmos dias dos realizados com a família de Iago. Dessa forma, primeiramente a vi, em uma das minhas idas na van escolar para buscar as crianças em casa. Posteriormente, fui de carro próprio a sua residência. Ao chegar, somente Irene estava em casa. Expliquei os objetivos da pesquisa e convidei-a para participar da mesma. Já ao final de entrevista, Irineu chegou do serviço, saindo em seguida para ir para a Faculdade na cidade.

Íris ficou à vontade durante a pesquisa, demonstrando tranquilidade ao longo de nosso diálogo. 


\subsubsection{A família de Flávio}

A família de Flávio era composta por sua mãe (Flaviana), seu pai (Flaviano) e seus três irmãos mais velhos. Flávio morava com os pais e dois irmãos que também estudavam na Escola Flamboyant. Um dos irmãos morava em outro Estado, com uma antiga vizinha de Flaviana.

A casa de Flávio localizava-se na fazenda onde Flaviano trabalhava e pertencia ao dono da mesma. A casa era muito simples, antiga e com uma estrutura desgastada e tinha poucos móveis. Na região próxima à residência de Flávio havia a casa de outro funcionário da fazenda (gerente) e a casa dos proprietários da fazenda, que moravam na cidade. A família do gerente era composta pelo mesmo, esposa e duas crianças. Os filhos do gerente, segundo Flaviana, mantinham uma relação próxima com Flávio e seus irmãos.

Flaviano trabalhava na fazenda realizando serviços diversos, como tirar leite de vacas e plantar. Já Flaviana trabalhava em sua residência. A família parecia viver em precárias condições de vida e não tinha muitos bens como, por exemplo, transporte próprio.

Flávio e sua família eram de outro Estado e haviam se mudado para o município A fazia uns 5 meses, considerando a época de realização da pesquisa. Segundo Flaviana, devido a esta mudança, a casa não tinha móveis, já que haviam deixado seus bens no outro Estado, chegando em Minas, conforme seus dizeres, "apenas com a roupa e uma bolsa”. A mesma pontuou que haviam mudado de cidade em busca de melhores condições de vida. Flaviana afirmou que a vida no outro Estado era difícil e que, todo ano, ela e Flaviano eram obrigados a deixar as crianças com a avó materna para irem ao interior de São Paulo em busca de empregos temporários. Em São Paulo, Flaviana trabalhava como doméstica e Flaviano no corte de cana. Devido a essas precárias condições de existência, a família optara pela mudança para Minas Gerais.

Meu primeiro encontro com Flaviana foi em uma reunião da Escola. Nesse dia, expliquei o objetivo da pesquisa e perguntei se gostaria de participar. A mesma disse, com certa timidez, que sim. Em semanas posteriores a este encontro, tentei descobrir qual van Flávio utilizava para que pudesse ir com seu motorista buscá-lo e ver onde morava. No entanto, não obtive essa informação: Flávio não sabia o nome do mesmo e os motoristas e profissionais da Escola também não tinham tal dado. Dessa forma, esperei o final de um dia escolar e, na saída, acompanhei Flávio até a van que iria levá-lo para casa. Ao chegar ao veículo, conheci os irmãos de Flávio que também estudavam na Escola. Após explicar e acordar com as crianças e com o motorista da van a minha ida à casa de Flávio, que foi 
consentida por todos, segui o veículo escolar, utilizando veículo próprio, até chegar à residência de Flávio. Lá encontrei Flaviana. Expliquei novamente a pesquisa e ela se prontificou a participar, autorizando as crianças a brincarem com os vizinhos (filhos do gerente) enquanto conversávamos.

Ao longo da entrevista notei que Flaviana, às vezes, ficava tensa. Em alguns momentos da entrevista, Flaviana manifestou que achava as questões difíceis de responder, buscando, porém, respostas para as mesmas e que, por vezes, foram pontuais. Após o término da entrevista, Flaviano chegou do trabalho. Cumprimentei-o e conversamos assuntos corriqueiros. Posteriormente, agradeci Flaviana pela participação na pesquisa e ao casal pela oportunidade de conhecê-los e pela boa receptividade.

\subsubsection{A família de Fabrício}

A família de Fabrício era composta por sua mãe (Fabíola), avô (Fabiano) e avó (Fabiana). Todos moravam e trabalhavam como funcionários de uma fazenda no município A. O pai de Fabrício havia falecido, porém, mesmo antes deste acontecimento, não chegou a morar com Fabrício e Fabíola, apesar de manter contato e certo convívio com os mesmos.

Fabíola era natural de uma cidade da região e, juntamente com seus pais, havia mudado para a fazenda onde residiam há mais de 20 anos.

Fabíola chegou a estudar até a antiga $8^{\mathrm{a}}$ série, ou seja, havia concluído o Ensino Fundamental. A mesma afirmou que, em grande parte de sua vida, morou na zona rural. $\mathrm{Na}$ época da pesquisa trabalhava auxiliando os pais nos serviços domésticos e da fazenda.

A casa onde moravam localizava-se dentro da fazenda onde trabalhavam e era pequena e muito simples, com uma estrutura antiga e bastante desgastada, o que, de acordo com Fabíola e Fabiana, incomodava e deixava a família constrangida. A família de Fabrício, assim como as famílias de Iago e de Flávio, conforme indicado acima, não tinha carro próprio.

Meu primeiro encontro com Fabíola foi quando fui buscar Fabrício em sua casa na van escolar, porém, nesse dia, não chegamos a conversar. O nosso segundo encontro foi em um evento na Escola, promovido pela instituição junto com alunos de uma Universidade Federal localizada no município A. Nesse dia, Fabíola falou sobre o filho e a Escola, bem como sobre outros assuntos corriqueiros. O terceiro encontro com Fabíola foi em uma Reunião de Pais promovida pela Escola. Antes da reunião conversamos um pouco e a convidei para participar da pesquisa. A mesma, sempre muito simpática, prontificou-se a participar do estudo. Ao final 
da reunião, ao saber que Fabíola iria voltar de mototáxi para casa, ofereci uma carona e fui até a sua casa, onde conheci seus pais. Nesse dia, Fabíola me forneceu seu telefone para que pudesse ligar para marcar nosso quarto encontro. Após ligar, fui novamente à casa de Fabíola e realizei a entrevista. Nesse dia, o pai de Fabíola estava no quintal realizando serviços da fazenda, e a Fabiana estava em casa. Esta ficou o tempo todo conosco e participou em alguns momentos da entrevista.

Fabíola e Fabiana ficaram à vontade ao longo da visita, demonstrando interesse e desejo de contribuir com o estudo, a partir do relato de suas experiências e visões. Em todos os encontros que tive com Fabíola, a mesma questionou-me sobre a Escola, requerendo informações e minha opinião sobre a mesma, assim como a mãe de Iago. Da mesma forma, tive de explicar que, por questões éticas, não poderia discutir e posicionar-me sobre tal temática, o que, a meu ver, foi bem aceito e compreendido por Fabíola. 


\section{CAPítUlO}

5

A RELAÇÃO ENTRE A ESCOLA FLAMBOYANT E AS FAMÍLIAS DO CAMPO

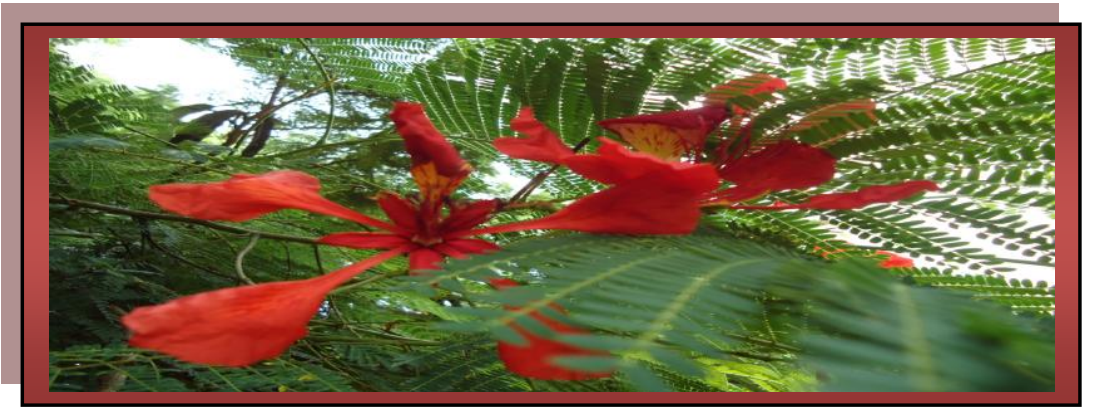





\section{A RELAÇÃO ENTRE A ESCOLA FLAMBOYANT E AS FAMÍlIAS DO CAMPO}

A partir da ida à Escola Flamboyant e às famílias do campo, houve a construção de dados que serão apresentados e discutidos a seguir, nos seguintes subcapítulos:

5.1. A Educação Infantil como (não) demanda das famílias do campo;

5.2. Objetivos da Educação Infantil no campo para as crianças/famílias do campo;

5.3. Os instrumentos da relação entre a Escola Flamboyant e as famílias do campo;

5.4. A relação Escola e famílias e as distâncias geográficas no campo;

5.5. Situações problemáticas na relação entre a Escola Flamboyant e as famílias do campo.

Cada subcapítulo, conforme já indicado anteriormente, é composto por itens que apresentam e discutem: 1) as significações das profissionais sobre a temática; 2) as significações das famílias sobre a temática; 3) aproximações e distanciamentos das significações das profissionais e das famílias sobre o tema do subcapítulo. 


\subsection{A EDUCAÇÃ̃ INFANTIL COMO (NÃO) DEMANDA DAS FAMÍLIAS DO CAMPO}

\subsubsection{Significações das profissionais da Escola Flamboyant sobre a (não) demanda de Educação Infantil no campo pelas famílias do campo}

Ao longo das entrevistas realizadas com profissionais da educação, houve o questionamento às mesmas se havia, na instituição escolar, demanda pelas famílias do campo por vagas na Educação Infantil, bem como a opinião das profissionais sobre a necessidade de ser oferecida esta modalidade de educação no contexto rural para as famílias e suas crianças de 0 a 5 anos.

A análise do material das entrevistas realizadas com as profissionais indicou que a discussão da demanda, pelas famílias do campo, por uma Educação Infantil no campo se diferenciou de acordo com a idade das crianças, ocorrendo diferentes discussões sobre a demanda de vagas para crianças de 5 anos, para as crianças de 4 anos e para as crianças de 0 a 3 anos.

No que se refere à questão da demanda de vagas para crianças de 5 anos pelas famílias do campo, as entrevistadas pontuaram:

“... Desde quando começou a Educação Infantil aqui, deixa eu ver, tem um tempinho... Aí tem a demanda, geralmente dá mais de 24 crianças de inscrição, só que a gente atende só 24 , porque não tem condição de atender mais, porque as salinhas não cabem...”. (Profissional Dirce)

“... Esse ano teve [lista de espera para 5 anos] Por que não teve vaga. Porque a gente só tem uma turma...". (Profissional Vilma)

Notamos que as entrevistadas indicaram a existência de uma demanda pelas famílias por vagas na Escola para as crianças de 5 anos e que não seria totalmente atendida, segundo Dirce, devido à estrutura da instituição. A existência de uma lista de espera na Escola para crianças de 5 anos foi mencionada. Vilma indicou ainda que tal lista às vezes sofria modificações ao longo do ano devido à rotatividade das famílias, que seria intensa, “... igual eu te falei a rotatividade aqui é muita. Então à medida que vai saindo aluno, vai entrando, vai saindo, vai entrando...".

Sobre a rotatividade das famílias e a demanda de vagas na Educação Infantil, Vilma afirmou ainda: 
“... É uma rotatividade grande, né? (...) Ao mesmo tempo em que na mesma região a gente tem uma quantidade ' $x$ ' de aluno, aí a... suponhamos, aí no início do ano a gente fica assim, com algumas vagas ociosas e de repente, chegam, né? De repente vão (...) É... funciona mais ou menos (...) A questão de safra, né? Porque nós estamos na zona rural, a questão de safra (...) De trabalho que é... de proposta de trabalho que tem, às vezes tem ano que não tem tanta proposta de trabalho na região, então ficam só os moradores, os proprietários, né?...”. (Profissional Vilma)

A rotatividade das famílias do campo apareceu como um elemento que influenciava a demanda pela Educação Infantil na Escola. Tal rotatividade é mencionada como estando entrelaçada à questão da oferta instável do trabalho naquele contexto rural, e que, por sua vez, estaria vinculada à questão dos períodos de plantio e colheita. Nesse cenário, a profissional indicou como a existência do trabalho na zona rural e a possibilidade de as famílias permanecerem no campo contribuiriam para o aumento da demanda pela Educação em territórios rurais.

A demanda por vagas para crianças foi indicada como sendo influenciada ainda por outras questões ligadas à vida no campo:

“... Desses anos pra cá que vem diminuindo [a demanda] desses assentamentos. Quando chegou tinha muita criança, mas eles chegaram, venderam os lotes, então é outra clientela, porque diminuiu, mas quando chegou em 96 os assentamentos tudo, aí... Chegou o assentamento Rio Claro e tudo, aí era uma demanda...! Aí davam duas salinhas [de 5 anos]...". (Profissional Dirce)

A profissional de educação afirmou que, com o processo de formação dos assentamentos rurais na região, a demanda por vagas na Escola teria inicialmente aumentado, o que implicou na abertura de mais uma sala de Educação Infantil na instituição. No entanto, posteriormente, de acordo com a entrevistada, houve a mudança da população assentada, o que resultou na diminuição da demanda de vagas na Escola para as crianças de 5 anos. Nesse contexto, evidencia-se a relação estreita entre a questão da Reforma Agrária e a da estruturação da Educação Infantil na Escola Flamboyant.

Sobre a demanda de vagas para as crianças de 5 a 4 anos, uma das entrevistadas pontuou outros motivos que influenciariam a mesma:

“... Olha a maioria a... assim, uma boa parte deles [famílias demandam vagas para Educação Infantil - 4 e 5 anos], é porque realmente querem que o filho comece a, tipo assim, ingressar na Escola um pouco mais cedo, né?, pra ter uma base melhor. Outros às vezes querem deixar ele aqui, porque se eles tiverem um compromisso, eles já têm onde deixar. Tipo assim, um hotelzinho (...) Agora não, mas já teve a... anos anteriores que o pai ia pra cidade, tinha dois filhos aqui, e passava lá e deixava o pequeno pra gente dar uma olhadinha, né?, até ele voltar, porque não sei o que que tem... Então, depois foi proibido essa questão de aluno ouvinte (...) O chamado 'aluno ouvinte'. Porque a gente já teve essa questão de aluno ouvinte. 'Não... tal, tal... ele vai ficar só como aluno ouvinte. A gente não vai fazer a matrícula dele não'. Mas o que que acontece? Com essa questão do transporte, 
do seguro do transporte e a segurança da criança, do Estatuto da Criança e do Adolescente [ECA], isso não é permitido mais...". (Profissional Vilma)

Vilma afirmou que havia famílias que demandavam Educação Infantil para suas crianças de 4 a 5 anos por reconhecerem a importância desta modalidade de educação na trajetória escolar da criança, o que indica a defesa, pela entrevistada, de uma concepção de que as famílias do campo valorizam a Educação de seus filhos. A entrevistada mencionou ainda que havia famílias que demandavam tais vagas para que pudessem deixar suas crianças em momentos que iriam exercer outras atividades, apontando a importância da Escola como instituição que compartilha o cuidado da criança com a instituição familiar.

Vilma relatou que, em tempos anteriores, os pais deixavam suas crianças na Escola esporadicamente, em momentos que necessitavam realizar atividades sem as mesmas, indicando a existência de uma escuta e atendimento da Escola das necessidades das famílias do campo e de outra forma de compartilhamento do cuidado da criança com os pais. No entanto, de acordo com Vilma, tendo em vista as normas vigentes do transporte escolar, tal forma de atendimento foi extinta, sendo obrigatória a matrícula da criança na Educação Infantil para que a mesma possa frequentar a instituição escolar, o que incentivaria a demanda de vagas na Escola para essa faixa etária.

Sobre a demanda de vagas para crianças de 4 anos, uma das entrevistadas afirmou:

“... Tem alguns casos esporádicos (...) de 4 anos, né? Seriam os menores (...) Mais nos 4 (...) 4 anos a 5. Porque a gente tem uma data 'x' pra fazer a inscrição, né? Então a criança nasce dois dias depois. Ai a mãe: 'Ah não, porque não sei o que que tem...' '. A gente tem que obedecer essa data. Ou às vezes quando não... nós já tivemos aqui, anos que não conseguimos montar uma sala, porque não tinha quantidade ' $x$ ' de aluno. Então a gente fez uma sala mista de cinco e quatro anos. Fizemos uma sala mista, que às vezes dava diferença, aquele é... de uma semana, mês só pra completar cinco. Então fizemos uma sala mista...”. (Profissional Vilma)

Notamos que houve indicação da demanda das famílias do campo pelo atendimento da criança de 4 anos na instituição. No entanto, tal atendimento parecia ocorrer em casos em que não se atingia o número de vagas para crianças de 5 anos oferecidas na Escola. Em casos em que não havia esta possibilidade - de preenchimento de vagas ociosas na sala de 5 anos - a Escola parecia recorrer à questão da idade para justificar para a família o não atendimento das crianças de 4 anos.

Sobre o atendimento da criança de 4 anos na instituição, profissionais pontuaram:

“...E Eu falei [para a secretária da Escola]: 'Faz [a inscrição de crianças de 4 anos] mas não vamos colocar eles', aí parece que deu 4 a 5 de 4 anos. Eu falei, 'Não, não vamos colocar porque é uma 
turma única, aí o que que acontece?, o ano que vem, ano que vem eles vão tá estudando aqui, chega no outro ano eles não vão seguir'. A gente pode montar uma turma de 4 e 5 anos, só que os 5 anos vai pra frente os 4 não (...) Até pela estrutura aqui da Escola, né?, fica mais complicado (...) pra gente estar atendendo, entendeu?, os meninos... Então é muito mais difícil, pra você ver, 4 anos é um bebê, né? Precisava ter um lugarzinho pra eles dormirem, né?, um colchãozinho pra hora que eles ficassem cansados, né?, e não tem essa estrutura pra estar... não pode ser dentro da sala, tá lá dentro da sala, 'Tia eu tô com sono', porque eles falam, 'Tia eu tô com sono', 'Eu tô com fome'. Entendeu? Como você coloca eles lá no chão, eles pra dormir ali no meio do outro, né?...”. (Profissional Vivian)

“... Um menino de quatro anos demanda berçário, uma coisa pra dormir, né? (...) Uma ducha, um lugar de tomar banho, porque até quatro anos eu acho que a Educação Infantil lá na cidade tem as professoras regentes e as educadoras infantis, né? A nossa aqui nós não temos, então... E os cinco anos lá também na cidade lá também já é só professora, então aqui só atende os 5 anos por causa disso, porque se não teria que mandar uma educadora infantil, ter o espaço físico com o lugar deles dormirem, porque eles dormem, tem que ser de preferência integral, nós não temos condições de atender crianças integral (...) não tem nem pessoa, estrutura humana... Como fala, estrutura humana, não, é... recurso humano pra ficar com essas crianças nesse intervalo dos que vão embora e dos que vêm, né?...". (Profissional Dirce)

De acordo com a fala de Vivian, notamos que a formação de agrupamentos mistos na Escola - com crianças de 4 e 5 anos - não é defendida pela entrevistada, tendo em vista que as crianças de 4 anos não ingressariam no ano seguinte no Ensino Fundamental. O fato de a instituição escolar seguir uma proposta de educação que se dá por etapas sequenciais e de acordo com a idade da criança, possuindo uma estrutura para este tipo de atendimento, parece constituir-se, para a entrevistada, como um elemento importante para justificar o não atendimento da criança de 4 anos, juntamente com as de 5 anos. Nas falas de Vivian e Dirce, notamos ainda que o reconhecimento de especificidades no atendimento da criança de 4 anos e, concomitantemente, a falta de condições $d a$ e $n a$ instituição escolar em contemplar tais especificidades também são mencionadas pelas entrevistadas para justificar o não atendimento da criança de 4 anos. A diferença entre as condições de atendimento das crianças de 4 anos na Escola Flamboyant e em instituições específicas de Educação Infantil, localizadas na cidade, foi ainda mencionada por Dirce que indicou estas últimas como estando preparadas para atender as crianças dessa idade, ao contrário do que ocorreria na Escola Flamboyant.

Sobre a demanda de vagas para crianças de 4 anos, outra entrevistada pontuou:

“... Não, tem não [demanda pra 4 anos], quando a gente faz inscrição aqui pra quatro dá no máximo 7 ou 6 alunos...”. (Profissional Dirce)

Notamos que Dirce defendeu a ideia de que não há demanda das famílias do campo para o atendimento de crianças de 4 anos na Escola. No entanto, em seguida, a entrevistada 
mencionou a existência de inscrições na instituição de 6 ou 7 famílias para o atendimento de crianças dessa idade. Dessa forma, a fala da entrevistada apontou que a solicitação de “poucas” famílias (6 ou 7) por vagas na Educação Infantil não era considerada pela profissional como sendo uma demanda, o que parece indicar que a entrevistada baseou-se em critérios quantitativos, necessários para montar uma turma, para avaliar o que seria demanda. Tal fato, a nosso ver, não privilegia as solicitações das famílias pela Educação Infantil quando as mesmas ocorrem em menores números. Apesar de ser diferente do que às vezes constatamos nas cidades - números grandiosos de famílias solicitando vagas na Educação Infantil - no campo, podemos lidar com números menores de solicitações por vagas, mas que se constitui como demanda dessas famílias.

No que tange à demanda por vagas para a faixa etária de 0 a 3 anos, a entrevistada pontuou ainda:

“... Não, não, os mais novos [0 a 3 anos] nem dá demanda, a gente nem faz inscrições mais porque eles não procuram, procuram um ou dois, acho que eles ficam mais preocupados com transporte, a criança muito pequena vir no transporte, andar em rodovia e aqui nós estamos ao redor de sete assentamentos, então é tudo muito longe (...) Uma mãe deixar uma criança vir sozinha numa van, quando é menor, eles já ficam assim mais preocupados, né? Então não tem demanda...". (Profissional Dirce)

Notamos que a solicitação por vagas na Educação Infantil para crianças de 0 a 3 anos realizada por uma ou duas famílias do campo não era vista como demanda pela entrevistada, não sendo tais pedidos registrados pela Escola, o que poderia contribuir, a nosso ver, para sua invisibilidade. No trecho mencionado, a "pouca" procura pelo atendimento da criança de 0 a 3 anos foi justificada pela entrevistada por uma suposta preocupação das famílias com o transporte das crianças das suas residências até a Escola, o que indica a concepção de que as famílias do campo estariam atentas com o bem-estar e segurança de seus filhos. No entanto, não houve a indicação, pela entrevistada, de um conhecimento construído pela Escola sobre esta temática a partir do diálogo ou de pesquisa com as famílias e que justificaria o menor número de solicitações pelo atendimento das crianças de 0 a 3 anos, “... acho que eles ficam mais preocupados com transporte...".

O desconhecimento da situação da demanda por vagas para crianças de 0 a 3 anos pelas famílias do campo foi indicado por outras entrevistadas:

“... É, se abrir vaga tem [demanda para 0 a 3 anos] Luciana, se a gente for falar que abre (...) Eu acredito que até tenha, sabe?, é, mas a Escola não tem como, né?, estar atendendo...". (Profissional Vivian) 
“... Pelo pouco tempo que eu tive aqui eu não sei te falar se tem demanda pra atender de 0 a 4. Mas estrutura não tem nenhuma (...) Não tem estrutura, porque de 0 a 3 as crianças ficam período integral (...) Tomam banho, almoçam, jantam, tem café da manhã, almoço, café da tarde, janta, banho no período da manhã, dependendo da necessidade, banho no período da tarde, eles dormem na Escola entre... Após o almoço eles têm o intervalo do sono. Então a estrutura física dessa Escola aqui não permite de 0 a $3 . . . ”$. (Profissional Poliana)

Notamos que Vivian, ao falar da suposição de que havia demanda na comunidade pelo atendimento no campo das crianças de 0 a 3 anos, indicou a impossibilidade de a Escola atender esta faixa etária, nas condições atuais de funcionamento. Poliana pontuou ainda que a tal inviabilidade ocorreria devido à estrutura física da instituição que não atenderia às especificidades desta faixa etária.

Além de discutirem a questão da Educação Infantil como (não)sendo uma demanda das famílias do campo, as profissionais realizaram ainda reflexões sobre a necessidade de haver o atendimento da criança de 0 a 5 anos nos territórios rurais. Sobre esta temática, profissionais afirmaram a necessidade da Educação Infantil no campo para atender aos pais que trabalham e necessitam de apoio no cuidado dos filhos, evitando o deslocamento da família para a cidade, em busca do atendimento na Educação Infantil, “... (A Escola é) um local que a mãe tem pra deixar o filho até pra trabalhar, né? (...) Pra eles né?, a distância também, mais perto do que ir pra cidade, né?..." (Profissional Vivian). Para outra profissional, o fato de haver Educação Infantil no campo traria ainda outros benefícios para as famílias, suas crianças e comunidades:

“... O pai se tiver todo esse, essa estrutura, esse suporte pros filhos dele [Educação Infantil no campo], é... ele vai ficar mais, ele vai ficar cultivando a terra. Se ele não tiver tudo aquilo que o filho dele se propõe a fazer, ou ele se propõe a oferecer pro filho, ele vai deixar sua terra e vai pra zona urbana (...) O homem é... ele ficando fixo na terra, todos nós ganhamos com isso, né? Porque a mão de obra pra zona rural ela é um pouco complicada. Porque todo mundo quer melhorar, quer fazer isso, quer fazer aquilo, aí... deixar o campo e ir pra zona urbana, né? Então se o... o... a criança tem a oportunidade de ficar aqui e ela vai vivendo naquele lugar, eu acredito assim, que a boa parte deles, o que eles aprenderam, eles vão trazer retorno, um bom retorno pra lugar onde eles moram (...) Assim, ser um agrônomo, ser um... um... veterinário, né?...”. (Profissional Vilma)

Vilma pontuou que o oferecimento da Educação Infantil no campo estaria entrelaçado com a questão da permanência do homem nos territórios rurais, o que seria importante para as crianças/famílias (que teriam a possibilidade de residir no campo), para a comunidade rural (que usufruiria o fato de as pessoas continuarem no campo e contribuírem com seus conhecimentos acadêmicos para a melhoria dos territórios rurais) e para a sociedade de uma forma geral (que necessita de trabalhadores no campo). O rural foi indicado pela profissional 
como sendo um lugar que ainda oferece condições de vida mais precárias às famílias em relação ao urbano.

Sobre a necessidade e a importância de haver Educação Infantil no campo, outra profissional afirmou:

“... Ai, eu acho que... Porque de 0 a 3 é Creche e de 4 a 5 é Educação Infantil, eu acho que a Educação Infantil mesmo, 4 e 5 sim, montando uma estrutura direitinho, com um ambiente adaptado para essa... Atendendo... Eu acho essencial [ter EI para 4 e 5 anos], porque a criança que faz a Educação Infantil, a gente nota a diferença quando ela passa pro Fundamental, do que aquela que vai direto pro Fundamental (...) Eu acho essencial, então se tivesse uma estrutura organizada para atendê-los, eu acho que 4 e 5 anos toda criança deveria ter, não só da zona rural como... não só da zona urbana como da zona rural, teria que ter a oportunidade, mesmo se viesse as nove crianças, que ficasse as nove, mas que tivesse os de quatro anos pra eles, né? Com essas salinhas, essas professoras, porque acho que é a base, a Educação Infantil é uma base pra criança, pra vida escolar dela...". (Profissional Dirce)

Notamos que Dirce identifica apenas a Pré-escola como sendo Educação Infantil, cindindo o segmento em Creche e Pré-escola. Evidenciamos fragilidades do conceito defendido pela profissional sobre a Educação Infantil, tendo em vista o que é preconizado nas legislações nacionais. A entrevistada defendeu a importância de haver o atendimento da criança de 4 e 5 anos do campo em instituições de Educação Infantil, sendo preciso o oferecimento de uma estrutura adequada para as crianças. A necessidade de igualdade de acesso da criança do campo em relação à da cidade foi indicada pela entrevistada. Dirce afirmou ainda que o atendimento deveria ser oferecido, mesmo que para um número menor de crianças, “... mesmo se viesse as nove crianças, que ficasse as nove, mas que tivesse os de quatro anos pra eles, né?...”, o que indica um afastamento de modelos urbanos/parâmetros quantitativos para se pensar a Educação Infantil no campo. No entanto, é importante ressaltar que a entrevistada defendeu a Pré-escola no campo, mas não a Creche no campo, “... Eu acho que aqui no campo, não precisaria de Creche não, de 0 a 3 anos não...”.

Sobre a questão do oferecimento da Creche no campo, outra entrevistada pontuou:

“... No pouco que eu, minha pouca convivência com o campo que agora minha mãe tá morando na cidade, mas ela morou também uns quatro anos no campo (...) Eu não acho necessário não, porque as familias do campo trabalham ali ao redor da residência (...) Então porque na cidade as crianças vão pra de 0 a 3 porque a mãe precisa deslocar da casa dela pra ir pro trabalho e aqui pelo pouco que eu conheço a impressão que eu tenho é que não tem essa necessidade de deslocar da casa dela pra ir pro trabalho, o trabalho tá ali ao redor da residência (...) Pode ser que pra um futuro a gente num... mas hoje eu não vejo necessidade não. E é muito melhor pra crianças de 0 a 3 ficar com os pais (...) Que ali que tá a formação todinha da criança, da personalidade da criança tá todinha na faixa etária de 5 até 7 anos, é a formação todinha da criança...”. (Profissional Poliana) 
Poliana, partindo da sua experiência, afirmou que as famílias do campo trabalham nas suas residências e, por isso, mencionou que não considera imprescindível a Creche no campo. A profissional relacionou a necessidade de Creche à distância entre o trabalho da mãe e seu local de residência. A ideia de que a família seria o ambiente mais propício para o cuidado e educação da criança de 0 a 3 anos também foi defendida pela entrevistada. Tal concepção também foi mencionada por outras profissionais, “... Se eu fosse, meus filhos hoje, acho que eu não colocaria assim tão pequenininho na Escola não, eu acho assim, aí acaba sendo ruim, eles cansam mais rápido, sabe? Eu não sei, eu vejo assim a idade acho que ideal pra menino ir pra Escola seria 6 anos” (Profissional Vivian); “... cada vez que o filho vai mais cedo pra Escola ele [pais] tá perdendo o tempinho que ele tem de ficar com a criança (...) de ver crescer..." (Profissional Vilma).

No entanto, diferentemente de Dirce e Poliana, Vivian - apesar de defender a família como sendo o local mais propício para o desenvolvimento da criança de 0 a 3 anos - afirmou a necessidade de ter Creche para tais crianças no campo, “... É eu acho, né? [que deveria ter EI], também ajudaria, né?, os pais, né?, eu acho que sim, que muita gente trabalha, né?, se na cidade tem porque não no campo, né?...". Nesta fala, notamos que Vivian defendeu que a existência de tal atendimento seria importante para possibilitar o trabalho dos pais, sendo ainda uma forma de igualdade de oportunidades para famílias do campo e da cidade.

No mesmo sentido, Paula indicou a necessidade de a Educação Infantil ser oferecida no campo para as crianças de 0 a 3 anos, porém afirmou que tal serviço deveria existir se houver demanda e um número mínimo de crianças a serem atendidas, “... Uai, eu acho que deveria ter que fazer um levantamento pra ver o número de pessoas que seriam atendidas, se tivesse um número mínimo eu acho que [deveria ter o atendimento na $\mathrm{EI}$ ] sim, né?...”.

Para uma das profissionais, a questão do número de crianças que seriam atendidas no meio rural apareceu como um dificultador, para se pensar sobre a questão de ter ou não o atendimento no campo para as crianças de 0 a 3 anos:

“... É difícil, é complicado, sabe? Por quê? Porque não seria praticamente é, seria como se fosse uma Creche, é eu não sei se a demanda seria tanto igual na cidade, porque de repente é um, dois alunos, três não compensa você montar, não que não compense montar turma, mas o prefeito não monta a turma (...) Não, porque como paga um profissional pra trabalhar com quatro, cinco crianças? Que deveria ter acho até que deveria ter sim, porque igual os EMEIs, na zona urbana tem os EMEIS. Aí é aqui na zona rural pode ser que não tenha tanta demanda. Eu acho assim, que se tivesse ele já teria montado...". (Profissional Patrícia) 
Percebemos que a entrevistada, ao pensar sobre a temática da Educação Infantil no campo voltada para o atendimento das crianças de 0 a 3 anos, indicou como a lógica do custo $\mathrm{x}$ benefício na Educação poderia inviabilizar o atendimento no campo. A necessidade de haver uma grande demanda parece despontar como algo necessário para o Poder Público viabilizar o atendimento. A entrevistada defendeu ainda que, se houvesse uma grande demanda das famílias do campo pela Educação Infantil, o município viabilizaria o atendimento nos territórios rurais, indicando a existência de uma gestão municipal que atende às solicitações das famílias por vagas na Educação Infantil nessas condições.

Sobre a questão da viabilização da Creche na comunidade rural, profissionais afirmaram:

“... Isso aí teria que fazer uma pesquisa, um levantamento pra ver o número de crianças que seriam atendidas, porque a Prefeitura ela tem (...) aqueles programas e aqueles limites mínimos pra se criar alguma coisa. Mas isso aí teria que partir no caso, da própria..., sei lá, porque aqui a gente não tem é, presidente, associação, não tem nada que vai dirigir como se diz, uma associação de moradores, alguma coisa... Aqui no caso, são pessoas que moram muito distantes uma da outra (...) dá mais ou menos quase 30 quilometros, perfazendo isso aí, então você fala assim, 'Ah então vamos criar uma Creche aqui e tal', e..., e tentar implantar isso, acho que nem a Prefeitura tem o interesse disso, porque na cidade, que é na cidade, já tem dificuldade pra se montar Creche, imagina na zona rural, que falta, não tem atendimento pra todos. E na zona rural eles, eles não têm interesse de montar isso aí não, não tô falando que não precisava, né?, mas essas crianças aí abaixo de 4 anos, no caso, quem mora na zona rural tem que esperar completar 4 anos pra então depois, hora que tiver de 4 pra 5 anos tem a vaga dela na Escola, mas realmente a possibilidade de criar uma Escola de 0 a 4 acho que na zona rural é meio difícil de acontecer...".

“... Eu acredito que futuramente que deva ter [atendimento para as crianças menores de 5 anos]... Eu acho que é uma questão assim, do... dos pais se mobilizarem, né? Irem até a secretaria de educação, né?, e tipo assim, fazer um abaixo-assinado com os pais daquela região, fazer um levantamento de crianças que tem nessa região, pra é... pedir, né?, uma estrutura que atenda essas crianças...".

Notamos que as entrevistadas defenderam a necessidade de mobilização das famílias, da comunidade para realizar a solicitação do atendimento da criança de 0 a 4 anos na zona rural junto ao Poder Público. Uma das profissionais, no entanto, indicou como tal mobilização pode ser dificultada na região devido à distância entre as residências das famílias do campo. A profissional apontou ainda que outro dificultador seria o não interesse do Poder Público em atender às populações do campo, indo de encontro à ideia, apresentada e discutida acima, de que o município atenderia às demandas do campo por Educação Infantil, caso existissem. O rural é citado como um local que possui acesso mais precário à Educação.

Vilma afirmou a necessidade de a iniciativa privada contribuir com a estruturação do atendimento da criança do campo na Educação Infantil: 
“... Que igual aqui, que nós temos é... essas empresas, né? (...) granjas na região e muitas vezes, a mãe pra trabalhar, trabalha o marido, a mãe vai trabalhar... ela arruma uma pessoa pra ficar com o pequeno (...) Pra ficar na casa de uma pessoa que vai ficar olhando aquela criança pra ela trabalhar. Então se tivesse o... as próprias empresas mesmo... As próprias empresas, que elas têm que contribuir com o social, poderiam criar um espaço desse pra atender essas crianças...". (Profissional Vilma)

Notamos que a entrevistada justificou a necessidade de a iniciativa privada atuar naquele contexto rural para garantir o acesso das famílias à Educação Infantil. A ausência de Creches gerava práticas informais de Educação Infantil como as realizadas por mulheres que tomam conta de crianças em suas residências. Sobre a existência das práticas de tais mulheres na comunidade, Vilma afirmou: “... Tem! Nossa! Muita! (...) É, tipo assim, eu... eu... 'Eu quero trabalhar', 'Então você faz assim, eu trabalho e você fica com o meu filho, e a fulana vai trabalhar, você fica com o meu'. Tipo assim, eu vou fazendo o meu salário, olhando essas crianças pra essas mães poderem trabalhar (...) As mães chegam contando pra gente...”.

Dessa forma, percebemos que houve a defesa pelas profissionais da existência de um atendimento formal de Educação Infantil no campo. No entanto, evidenciamos que as entrevistadas atribuem à iniciativa privada a função de oferecer o atendimento ou ao Poder Público diante da mobilização e demanda das famílias. Não notamos nas falas das profissionais a indicação da própria Escola Flamboyant como sendo também uma das protagonistas no entendimento e sistematização da demanda por Creches e Pré-escolas no campo, para subsidiar a ampliação ou criação de vagas.

Sobre a Educação Infantil existente na Escola, uma das entrevistadas destacou como a Educação Infantil no campo vem sendo estruturada diante da demanda das famílias do campo:

“... A nossa Escola não foi estruturada pra atender crianças do Ensino Infantil, nossa Escola é Ensino Fundamental, nosso regimento é Ensino Fundamental, nós não temos regimento que atenda a Educação Infantil. Aí aqui, a Educação Infantil nessa Escola, ela é implantada só pra atender a solicitação dos pais de demanda de crianças de cinco anos (...) Mas nós não temos espaço, pra você ver, é perigoso pra a criança... o espaço próprio para atendê-las, né? (...) nós pusemos vasos pequenininhos pros meninos, mas na verdade ela não é pra atender as crianças, inclusive a gente faz uma inscrição, só se der uma turma que a gente monta, se não der a gente não monta...”. (Profissional Dirce)

A demanda das famílias apareceu como um elemento importante para a viabilização do atendimento da Educação Infantil no campo. No entanto, no trecho acima, evidenciamos como, para a entrevistada, a estruturação do atendimento da Pré-escola na Escola Flamboyant não resultou na construção de uma identidade da Educação Infantil, já que a Escola ainda é descrita como sendo somente de Ensino Fundamental. A questão da garantia da vaga foi 
indicada, mas não o oferecimento de uma Educação Infantil que garanta a qualidade do atendimento no que se refere à segurança da criança.

Sobre o atendimento da Educação Infantil na Escola Flamboyant, uma das profissionais afirmou ainda:

“... A gente segue as diretrizes [municipais de Educação Infantil], mas muita coisa não dá pra atender, hora de banho, hora de brincadeira, espelho, a gente tenta adaptar da melhor forma, igual é obrigatório ter o espelho grande, então a gente tem só um pequenininho lá pra ver o meni... A criança... Mas não é da forma como são estruturadas as Escolas da zona urbana...".

“... [Profissionais da Prefeitura] falam 'Nós vamos abrir educaçãozinha infantil aí para vocês pra atender a comunidade, mas não é aquela Educação Infantil moderna que nós temos aqui não viu?' (...) 'É para atender a demanda da melhor forma que vocês puderem atender vocês atendem, mas não é toda estruturada pra ser uma Educação Infantil não'...”.

Notamos que a entrevistada relatou dificuldades de oferecer estrutura física apropriada às crianças pequenas e indicou limites na promoção de um atendimento adequado da Educação Infantil na Escola. A profissional afirmou que o Poder Público defenderia a lógica da garantia de vagas - diante da demanda das famílias do campo -, mas reconheceu o oferecimento de um serviço inferior ao disponibilizado na cidade e sem a devida qualidade.

A partir dos trechos apresentados acima, percebemos que as profissionais de educação indicaram a existência de solicitações de vagas na Escola em número maior para crianças de 5 anos (reconhecendo-as como sendo demanda das famílias por Educação Infantil) e a existência de menos solicitações de vagas para crianças de 0 a 4 anos (o que não é considerado, por algumas entrevistadas, como sendo demanda). Profissionais afirmaram ainda a necessidade de ser oferecida Pré-escola no campo. Já no que se refere à Creche, percebemos que houve a defesa de diferentes pontos de vista, sendo que algumas profissionais afirmaram não haver a necessidade de ser oferecida esta modalidade de educação no campo, enquanto outras entrevistadas indicaram a necessidade de existir Creche na zona rural.

Ao discutirem a (não)demanda pelas famílias do campo por Educação Infantil, percebemos que as profissionais de educação apontaram elementos que influenciariam tal demanda pelas famílias, sendo os mesmos diferenciados para Creche e Pré-escola. A demanda por Creche seria atenuada, de acordo com as falas das profissionais, tendo em vista o uso do transporte escolar pelas crianças pequenas, o que seria visto pelas famílias como algo arriscado. Tal risco seria ainda maior considerando as grandes distâncias existentes entre as 
instituições Escola e família, o que também contribuiria para reduzir a demanda dos pais pela Creche. No que tange à Pré-escola, apreendemos que, para as profissionais, contribuiria para atenuar a demanda por esta modalidade de educação a mobilidade dos assentados devido à venda de lotes e, ainda, a precariedade de trabalho na comunidade na época de entressafra, o que também fazia com que famílias se deslocassem para outras regiões em busca de trabalho. Nos períodos de plantio e colheita, ao contrário, a demanda pela Pré-escola seria intensificada. A demanda por vagas na Pré-escola seria intensificada ainda, segundo as falas das profissionais, por características das famílias atendidas que desejam que seus filhos ingressem na Escola, considerada como local de aprendizagem e, ainda, que necessitam que a Escola complemente o cuidado e educação da criança para que possam exercer outras atividades, dentre elas, as de trabalho. Tais elementos, apreendidos nas falas das profissionais e que influenciariam a demanda pela Educação Infantil no campo, se relacionariam com características das crianças (faixa etária), das famílias (concepções sobre transporte escolar e Educação Infantil, condições concretas de vida e de trabalho) e do contexto rural (distância geográfica, oferta de trabalho, dinâmica da Reforma Agrária).

Entrevistadas mencionaram ainda que é a demanda das famílias pelo atendimento dos filhos de 5 anos na Escola que mantém o atendimento de crianças desta idade na instituição escolar. Ressaltaram, porém, que o mesmo é precarizado em relação ao atendimento ofertado em instituições da cidade, sendo que a estrutura da Escola não contempla as especificidades das crianças da Educação Infantil. Tais significações sobre a Educação Infantil no campo parecem ser construídas tendo como parâmetro as experiências do mundo urbano. A referência às cidades ainda ocorre em diversos momentos e parece influenciar não só a forma como veem o atendimento da Educação Infantil na Escola Flamboyant (inferior ao oferecido no contexto urbano), como concebem o que é demanda (numerosas solicitações por vagas, como ocorre na cidade), mas também como avaliam a necessidade de haver Educação Infantil no campo. Segundo profissionais, deve ser oferecida Educação Infantil no campo (Creche e Pré-escola), tendo em vista a necessidade de garantir uma igualdade de direitos entre famílias e crianças do campo em relação às citadinas.

Ao opinarem sobre a necessidade ou não de haver Creches e Pré-escolas na zona rural percebemos ainda que as profissionais mencionaram critérios para avaliarem a necessidade de Educação Infantil no campo, sendo os mesmos ora semelhantes e ora diferenciados para Creche e Pré-escola. Segundo as profissionais, tanto a Creche como a Pré-escola seriam necessárias no campo como forma de garantir uma igualdade de direitos entre campo e cidade, conforme citado acima, e, ainda, para viabilizar o trabalho dos pais, permitindo a 
permanência da família no campo e evitando o êxodo rural. A Pré-escola também seria necessária para possibilitar processos de aprendizagem e desenvolvimento da criança. Houve profissionais que argumentaram que a Creche seria desnecessária no campo, havendo a defesa da família como melhor local para a criança pequena se desenvolver. Tais critérios pautamse, dessa forma, em questões relativas ao direito da criança e da família; em concepções sobre desenvolvimento infantil e família; e em condições concretas de vida e de trabalho das famílias.

Como forma de sistematizar os dados acima, construímos os quadros apresentados a seguir:

\begin{tabular}{|c|c|c|}
\hline Modalidade & \multicolumn{2}{|c|}{ Elementos que influenciam a demanda por EI } \\
\hline \multirow[t]{2}{*}{ Creche } & $\begin{array}{l}\text { Características das crianças e } \\
\text { famílias }\end{array}$ & $\begin{array}{l}\text { Faixa etária da criança associada à necessidade de } \\
\text { transporte escolar: Famílias avaliam o transporte } \\
\text { escolar para as crianças pequenas como sendo mais } \\
\text { arriscado, o que atenua a demanda. }\end{array}$ \\
\hline & $\begin{array}{l}\text { Características/especificidades do } \\
\text { contexto rural }\end{array}$ & $\begin{array}{l}\text { Grande distância geográfica entre Escola e } \\
\text { família: torna o transporte escolar mais arriscado } \\
\text { para crianças pequenas, o que atenua a demanda. }\end{array}$ \\
\hline \multirow[t]{3}{*}{ Pré-escola } & \multirow[t]{2}{*}{ Características das famílias } & $\begin{array}{l}\text { Concepções sobre Educação Infantil: Desejam que } \\
\text { seus filhos ingressem na Escola para aprenderem, o } \\
\text { que intensifica a demanda. }\end{array}$ \\
\hline & & $\begin{array}{l}\text { Condições concretas de vida e de trabalho das } \\
\text { famílias: Famílias precisam deixar suas crianças na } \\
\text { Escola para trabalhar e exercer outras atividades, o } \\
\text { que intensifica a demanda. }\end{array}$ \\
\hline & $\begin{array}{c}\text { Características/especificidades do } \\
\text { contexto rural }\end{array}$ & $\begin{array}{l}\text { Oferecimento de trabalho no campo: Maior em } \\
\text { período de plantio e colheita, o que permite a } \\
\text { permanência das famílias no contexto rural e } \\
\text { intensifica a demanda para a Pré-escola. Menor em } \\
\text { período de entressafra, o que atenua a demanda. } \\
\text { Dinâmica da Reforma Agrária: Venda de lotes de } \\
\text { assentamentos atenua a demanda. }\end{array}$ \\
\hline
\end{tabular}

Quadro 13 - Elementos que influenciam a demanda por EI - Relatos das profissionais 


\begin{tabular}{|c|c|c|}
\hline Modalidade & \multicolumn{2}{|c|}{ Critérios para avaliar a necessidade de EI no campo } \\
\hline \multirow[t]{3}{*}{ Creche } & Direito da criança e da família & $\begin{array}{l}\text { Necessária - Igualdade de direitos entre campo e } \\
\text { cidade. }\end{array}$ \\
\hline & $\begin{array}{l}\text { Condições concretas de vida e de } \\
\text { trabalho das famílias }\end{array}$ & $\begin{array}{l}\text { Necessária - Famílias precisam deixar suas crianças } \\
\text { na Escola para trabalhar. Permite a permanência da } \\
\text { família no campo. Evita deslocamento para a cidade } \\
\text { em busca da EI. } \\
\text { Desnecessária - Famílias não precisam deixar suas } \\
\text { crianças na Escola para trabalhar. }\end{array}$ \\
\hline & $\begin{array}{l}\text { Concepções das profissionais sobre } \\
\text { desenvolvimento infantil e família }\end{array}$ & $\begin{array}{l}\text { Desnecessária - Família vista como melhor local } \\
\text { para o desenvolvimento da criança. }\end{array}$ \\
\hline \multirow[t]{3}{*}{ Pré-escola } & Direito da criança e da família & $\begin{array}{l}\text { Necessária - Igualdade de direitos entre campo e } \\
\text { cidade. }\end{array}$ \\
\hline & $\begin{array}{l}\text { Condições concretas de vida e de } \\
\text { trabalho das famílias }\end{array}$ & $\begin{array}{l}\text { Necessária - Famílias precisam deixar suas crianças } \\
\text { na Escola para trabalhar. Permite a permanência da } \\
\text { família no campo. Evita deslocamento para a cidade } \\
\text { em busca da EI. }\end{array}$ \\
\hline & $\begin{array}{l}\text { Concepções das profissionais sobre } \\
\text { Educacão Infantil }\end{array}$ & $\begin{array}{l}\text { Necessária - Importante para a aprendizagem e } \\
\text { desenvolvimento da criança. }\end{array}$ \\
\hline
\end{tabular}

Quadro 14 - Critérios para avaliar a necessidade de EI no campo - Relatos das profissionais

\subsubsection{Significações das famílias da Escola Flamboyant sobre a (não) demanda de Educação Infantil no campo pelas famílias do campo}

Ao longo das entrevistas realizadas com as famílias do campo, houve o questionamento às mesmas: sobre qual idade suas crianças começaram a frequentar a Educação Infantil/a Escola Flamboyant e se tal idade foi a desejada pela família; sobre a oferta de vagas da Educação Infantil na Escola Flamboyant; se identificavam na comunidade rural a existência de demanda por vagas da Educação Infantil e se (não) consideravam necessária a oferta de Educação Infantil nos territórios rurais.

No que tange ao ingresso das crianças das famílias entrevistadas na Educação Infantil, a partir da análise das entrevistas, constatamos que houve diferenciações entre algumas famílias no que se refere à idade que matricularam seus filhos na Educação Infantil, bem como em relação ao desejo das mesmas sobre a idade que gostariam que tal fato ocorresse. Para a discussão dessa temática, é importante mencionar que as famílias de Artur e de Flávio residiam na zona urbana quando estes estavam na faixa etária dos 0 a 4 anos. A família de Iago mudou-se para a zona rural quando este estava com 1 ano. Já as famílias de Ísis e Fabrício sempre residiram com seus filhos no campo. 
Adriana afirmou que matriculou Artur aos 2 anos em uma Creche particular na zona urbana do município A. Em relação à idade que Artur ingressou na Educação Infantil, a genitora relatou:

“... Quando ele tinha 2, 3 aninhos, ele ficou na escolinha particular, sabe? A gente pagou a escolinha particular e ele ficou... eu trabalhei um ano aí depois saí (...) Como eu achava injusto eu ficar em casa e ele na escolinha, ai eu ficava pensando, 'Nossa, mas ele é tão pititinho pra ficar lá na Escola e eu aqui em casa, se eu tivesse ao menos trabalhando', aí eu peguei e tirei ele (...) Depois eu mudei pra uma casa lá no Bairro Itacaré que tem uma EMEI pertinho. Aí eu resolvi trabalhar, fazer bico, esses trem, aí eu falei, 'Vou ver se eu consigo uma vaga pra ele'. Aí consegui, né? Aí ele ficou muito tempo (...) Aí ele ficou até eu vir pra cá, né?...”. (Genitora Adriana)

Adriana relatou que a ida do filho para a Creche ocorreu devido ao fato de trabalhar fora do âmbito doméstico, havendo inclusive a retirada da criança da Educação Infantil no período em que trabalhava em sua residência. A matrícula de Artur na Educação Infantil de 2 a 4 anos pareceu ser defendida/justificada pela entrevistada pela necessidade de trabalho da genitora.

Diferentemente da família de Artur, a família de Flávio matriculou a criança com 4 anos em uma instituição localizada em uma cidade da Bahia, na qual residiam em período anterior à sua mudança para o município A. A genitora de Flávio, ao ser questionada se a idade que seu filho ingressou na Educação Infantil correspondia ao desejo/necessidade da família, afirmou:

“... Ah, eu queria colocar ele depois, depois dos, assim, dos cinco, dos quatro anos. Depois dos quatro (...) Coloquei um pouquinho antes (...) Eu coloquei por causa que ele via os outros meninos e ele chorava dizendo que queria ir... Aí eu peguei e deixei porque a Escola era pertinho (...) 'Ai, eu quero ir pra Escola mais os meninos', ele chorava mesmo pra ir, aí eu falei 'Vai, vai'. Aí ele ia, estudar lá...”. (Genitora Flaviana)

Notamos que Flaviana justificou a ida da criança para a Pré-escola com 4 anos, tendo em vista a solicitação de Flávio de acompanhar seus irmãos que frequentavam a mesma instituição escolar. No entanto, a mesma indicou o desejo de que a criança fosse para a Escola após os 4 anos. Em outro relato, a genitora de Flávio defendeu a ideia de que a família seria o melhor local para a criança de 0 a 4 anos se desenvolver, indicando que nesta faixa etária a criança “... é muito pequena pra ir pra Escola...”.

Já as famílias de Íris, Fabrício e Iago matricularam seus filhos com 5 anos na Escola Flamboyant. Para a genitora de Íris, tal idade seria a ideal para a criança ir para a instituição escolar, conforme consta na fala abaixo: 
“... Na realidade pra mim foi na idade certa [5 anos], né? Pra mim. Agora, meu esposo já achava assim 'Ai, vamos deixar pra colocar mais... eles mais... né?, velhos', 'Mas porque mais velhos?', ai ele falou assim: 'Ah, porque eu, quando eu estudei, comecei com sete anos'. Eu quando estudei fui com sete anos, mas não tinha isso na minha época, né? Porque eu creio que se tivesse meus pais teriam me colocado também (...) Então a minha sogra achava um horror eu colocar meus meninos com cinco anos, porque... 'Ah porque tá tirando a liberdade deles, porque eles tão muito pequinininho, não brinca mais... Por isso e tal...' (...) 'Porque a partir do momento que eles começam estudar, nunca mais para'. Falei 'Gente, mas um dia vai ter que estudar!' (...) Então se tem agora... Não é uma coisa assim... Eu sou obrigada a colocar? Não, eu não sou obrigada a colocar. Mas pra eles depois... Já pensou? A Íris entrasse com sete anos? O ano que vem ela ia entrar ainda! (...) Então eu achei que eu coloquei na idade boa assim (...) Não, eu nunca pensei [em colocar antes]. Era essa idade pra mim (...) O certo foi essa idade...". (Genitora Irene)

Irene indicou como a definição/decisão da idade da criança ir para a Educação Infantil/Escola foi um ponto de dissensos no âmbito familiar, sendo que a mesma avaliou que a idade adequada seria 5 anos, porém o genitor e a avó de Íris consideravam que seria 7 anos, justificando tal escolha a partir do argumento de que a Escola restringiria a liberdade e as atividades lúdicas das crianças. No relato apresentado, notamos ainda que os argumentos utilizados pelos familiares para justificar a (não) ida de Íris para a Escola se vinculam com a questão do bem-estar da criança e com a concepção de Educação Infantil como Escola que prioriza o estudo e que limita o tempo da criança para brincar e viver a infância.

Ao contrário de Irene, Inês e Fabíola manifestaram o desejo de que suas crianças tivessem frequentado a Educação Infantil a partir dos 4 anos de idade:

“... Se tivesse jeito eu tinha colocado ele com 4 porque eu acho muito importante a Escola (...) Se tivesse opção tinha posto ele com 4 na Escola. Então quando ele completou 5, antes dele completar eu tinha feito a matrícula, né? (...) Logo que começou a fazer a matrícula eu fiz a matrícula dele lá...". (Genitora Fabíola)

“... Eu queria ter posto ele com 4 anos justamente por causa do problema dele (...) Que nem o médico falou: 'Quanto mais rápido ele, ele entrar dentro de uma Escola, pra trabalhar com outras crianças, pra ele ter contato com outras crianças ele tanto ia melhorar a fala, né?', porque ele ia ter contato com outras crianças, como [ia melhorar] o comportamento dele (...) Tanto é que ele, a fala dele melhorou noventa por cento... A gente entende praticamente tudo que ele fala (...) Aí eu não pus o ano passado, por isso, por que ali não tinha de quatro (...) E na cidade tinha mas não tinha como estar levando...". (Genitora Inês)

Nos trechos apresentados, notamos que famílias indicaram que o desejo de que seus filhos tivessem tido a oportunidade de frequentar a Pré-escola com 4 anos se relaciona com a concepção de que esta modalidade de educação possibilita aprendizagens para as crianças. No relato de Inês, percebemos ainda que discursos médicos sobre a importância da Pré-escola para o desenvolvimento da criança - no caso de Iago, para o desenvolvimento da fala - por 
meio das interações criança-criança despontaram como um elemento importante que interfere na demanda da família pela Pré-escola no campo, para crianças de 4 anos. Apesar de ser uma demanda de famílias do campo, o oferecimento da Educação Infantil para as populações rurais foi indicado como sendo precário pela genitora de Iago, que afirmou que tal atendimento existe na cidade, mas que é inacessível às famílias do campo, tendo em vista a impossibilidade de deslocamento para o meio urbano.

Apesar de demandarem o atendimento na Educação Infantil para as crianças de 4 anos no campo, as famílias de Fabrício e Iago afirmaram que não desejaram que seus filhos frequentassem a Creche na faixa etária dos 0 a 3 anos, conforme consta nos relatos abaixo:

“... Não. Antes dos 4 eu não teria coragem não [de matricular o filho na EI], pra mim criança acho que tem que é... pra mim tem que ficar em casa, assim com o pai, com a mãe e... e... hoje em dia a maioria dos pais é um tal de colocar com dois aninhos, já coloca na escolinha já, né? Aí você vê aquelas criança pititinha já de mochilinha nas costas, de uniforme, não sei o quê... Eu acho que tira um pouco da liberdade da criança ser criança (...) Você entendeu? Por mais que eu sei que nessas escolinhas, eles brincam tal, mas tem as regras e eu acho que criança muito pequenininha não tem muito que ter regras, apesar que tem que ter limite...”. (Genitora Inês)

“... Não. Aí eu não colocaria não [antes dos 4 anos] (...) Não. Não colocaria, por eu não estar trabalhando fora, eu não ia precisar deixar ele com ninguém. Eu não colocaria (...) Não, eu acho que não havia necessidade mesmo, né? Você vê, tem eu, a mamãe pra olhar ele. Então não precisaria por lá (...) Além de estar ocupando vaga de outras mães que estão trabalhando e também ia até judiá dele, né?, sendo que ele podia ficar mais tempo aqui com a gente, que ele não estava atrapalhando em nada. Igual tem mãe que manda o filho pra Escola pra se ver livre dele, né? Eu mando o Fabrício pra Escola pra aprender mesmo. Portanto pra você ver que está conversando comigo, que eu luto mesmo pelas coisas dele, pelos interesse dele...". (Genitora Fabíola)

Percebemos que as genitoras de Iago e de Fabrício defenderam a concepção de que a família seria o melhor lugar para a criança de 0 a 3 anos ser cuidada e educada. A ida para a Escola nesta faixa etária foi considerada por Inês e Fabíola como sendo algo que pode trazer prejuízos para a criança, “... Eu acho que tira um pouco da liberdade da criança ser criança...”, “... também ia até judiá dele...”. A frequência da criança na Creche foi justificada por Fabíola em casos que a genitora necessita trabalhar fora do âmbito doméstico.

Em outros relatos, Inês e Inácio apontaram ainda que houve a opção pelos genitores de que Inês abdicasse de seu trabalho em uma empresa da região para trabalhar no ambiente doméstico e se dedicar a Iago:

“... Pedi pra eles me mandar embora e resolvi não trabalhar mais, ficar quieta em casa cuidando do Iago... Aí eu comecei a pegar olhar criança em casa, né? (...) É, aí depois que saiu as crianças, aí eu falei, 'Ah, vou pegar umas roupas pra lavar e passar, né? '...". (Genitora Inês) 
“... Ela não optou por trabalhar, porque ela queria trabalhar, porque justamente por motivo do Iago do jeito dele não tinha condições de deixar ele com ninguém, não tinha confiança de deixar ele com alguém do jeito que ele é (...) Ia trabalhar que jeito, né? Tinha que cuidar dele (...) Vamos supor que fosse trabalhar, que jeito que ia trabalhar?, e deixar ele em Creche? Ele não ia conseguir às vezes, ficar na Creche..." (Genitor Inácio)

“... A gente podia ver com algum vizinho pra olhar ele, mas como ele é muito agitado, custoso, então nós não confiava não deixar ele com ninguém, ele quebrou o braço com dois anos de idade (...) Ixe, $e$ isso junto com nós (...) A gente vive um pouquinho mais apertado, mas pelo menos a gente tem a consciência de que é a gente que cuida dele...". (Genitora Inês)

Percebemos que os pais de Iago, apesar de indicarem outros ambientes para a criança ser cuidada e educada dos 0 a 3 anos - como Creche e em residências de vizinhos - não os consideraram os mais adequados para o desenvolvimento do filho e optaram pela reestruturação da dinâmica e do orçamento familiar, para que Iago fosse cuidado e educado exclusivamente pela família até os 5 anos, quando tornou possível a ida da criança para a Préescola na Escola Flamboyant. Os pais de Iago mencionaram que a permanência de Iago exclusivamente na família dos 0 a 3 anos foi importante, tendo em vista o fato de considerarem o filho como sendo "muito agitado, custoso".

Notamos, dessa forma, que as famílias entrevistadas defenderam idades ideais diferenciadas para que as crianças frequentassem a Pré-escola. No entanto, percebemos que há um consenso de que a família é o local mais adequado para a criança de 0 a 3 anos se desenvolver. Apesar de defenderem tal concepção, entrevistadas indicaram que há na comunidade rural uma demanda por Educação Infantil para crianças de 0 a 4 anos, conforme indicam os relatos abaixo:

“... Tem uma menina ali, o menino dela é... Sabe esses meninos bem formadão, parecendo que tem uns 6 anos? (...) Aí toda vez que eu chego lá na casa dela eu pergunto assim: 'Você não foi pra Escola?'. Eu esqueço que o menino tem 4 anos... Aí ela: 'Não, mas esse menino vai pra Escola só o ano que vem'. Ai eu falei assim: 'Nossa, eu esqueço que ele tem 4 anos'. Ai ela fala assim: 'Eu não vejo a hora de chegar o ano que vem pra esse menino ir pra Escola' (...) Então ela queria que tivesse. Igual a mulher do caseiro também tem uma menininha de dois anos e ela também queria que a menininha já tivesse na escolinha, mesmo que fosse igual... tipo uma coisinha, pra ela entreter...". (Genitora Adriana)

“... Eu tenho uma irmã que a menina dela mais nova tá com quatro anos. Ela foi lá [Escola Flamboyant] pra fazer inscrição da menina. Ai eles falaram assim: 'Ah, porque a gente não pega e tal... Porque ela é muito pequenininha, mas vamos pôr o nome dela aqui na lista. Mas não vamos garantir que a gente vai pegar ela não... Pela idade dela, então a gente dá preferência pros outros mais velhos que ela' (...) Então, aí é difícil... porque eu acho que a menina igual ela vai fazer cinco anos naquele ano, por causa de um mês eles não pegam (...) Eu acho que eles poderiam pegar sim...”. (Genitora Irene) 
“... Já teve caso de vizinho nosso do outro lado do... da fazenda aqui que já precisou de vaga pelo fato que eu te falei, da mãe trabalhar, né?, e não ter com quem ficar a criança, não tinha onde colocar (...) Trabalhava num laticínio que tinha aqui do lado. Até já fechou agora mas já houve mais casos. Tem vizinho que você sabe de fazenda assim que você conversa de longe, que já precisou de colocar criança menor de 5 anos e não tem como, não tem onde...". (Genitora Fabíola)

Notamos que as famílias mencionaram a existência de demanda na comunidade rural por Creche e Pré-escola no campo que chegava inclusive à Escola Flamboyant, havendo a formação da lista de espera na instituição escolar. Tal demanda, segundo entrevistadas, relacionava-se com a necessidade de os pais trabalharem. Diante da ausência de tal atendimento, famílias entrevistadas apontaram que pais do campo buscavam alternativas para resolver tal problemática:

“... Tinha [família com criança menor de 3 anos], na época tinha, e não tinha onde deixar a criança, por que a Escola Flamboyant só pega com 5 (...) Ela ficou com a criança em casa, trabalhando, olhando a criança e trabalhando, porque não tinha com quem deixar (...) Teve um tempo que a nossa vizinha aqui, a mãe do Pedro Henrique que eu estou te falando, deixou, chegou a levar o filho dela pra mãe dela, porque ela precisou trabalhar pra ajudar o marido porque eles ficou meio com dificuldade... Só que eles tinha carro próprio e ela levava o menino dela lá pra mãe dela, lá no Bairro Canápolis [na cidade]... era um sacrifício danado que eles fazia aí pra poder ela conseguir trabalhar (...) Todo dia, ele tinha que sair mais cedo antes do horário dele, né?, pra ele levar o menino lá e depois voltar, levava ela já junto pra ela trabalhar e depois de tarde ia pegar (...) É, na fazenda o trem não é fácil não...". (Genitora Fabíola)

“... A Rejane continua trabalhando, a menina dela fica em Creche, mas na cidade (...) Trabalhava no escritório [da Indústria Granjeira] (...) É... eu cheguei a olhar uma criança, mas cheguei a olhar pouco tempo, porque aí parece que depois ela arrumou alguma coisa na cidade...". (Genitora Inês)

Percebemos que houve a indicação que famílias do campo, diante da falta de atendimento de suas crianças de 0 a 4 anos na Educação Infantil no campo, buscavam soluções para esta questão, tais como: a genitora abandonava o trabalho no âmbito extradoméstico para cuidar e educar a criança; genitores levavam a criança diariamente para ficar com a avó materna, que residia na cidade; genitores levavam o filho para instituição de Educação Infantil localizada na cidade e deixavam o campo. Diante da necessidade de as famílias do campo trabalharem e, concomitantemente, da ausência de Educação Infantil na zona rural, Inês afirmou, inclusive, que vinha realizando o trabalho de tomar conta de crianças da comunidade em sua residência para que os pais, que pagavam pelo serviço, conseguissem exercer suas atividades profissionais: “... Eu cheguei a olhar muitas crianças de funcionários que trabalhava ali (...) Olhava em casa (...) Olhei, por exemplo, a Pâmela, eu olhei a filha da minha vizinha aqui que ela trabalhava. Eu olhei a filha dela, depois eu olhei as duas filhas dela quando ela teve neném, que ela teve que voltar a trabalhar, né? Então eu olhei... teve 
uma época que eu olhei, eu estava com as duas nenéns (...) Eu já cheguei a ficar com... com as duas Samiras, com a Samara, com a Samanta, quatro mais o Iago cinco, com cinco crianças...".

Notamos que as famílias rurais buscavam administrar de diferentes formas, dentro das possibilidades existentes, as questões relativas ao trabalho no campo com o exercício da maternidade/paternidade, tendo em vista a ausência de Creche e Pré-escola para crianças de 0 a 4 anos na região onde moram. Fabíola ressaltou ainda que as condições de vida no campo (como acesso à Educação) eram mais difíceis do que na cidade, “... É, na fazenda o trem não é fácil não...”, o que aponta para uma desigualdade de oportunidades para famílias que é determinada pela questão geográfica, ou seja, pelo local de moradia das mesmas: no meio urbano ou rural. A ida de famílias para a cidade, em busca de melhores condições de vida, foi apontada por entrevistadas: “... aí parece que depois ela arrumou alguma coisa na cidade...”.

As falas mostraram que a ausência da Educação Infantil nos territórios rurais, ao dificultar as condições de existência das famílias do campo, contribui para a saída das mesmas do campo para a cidade em busca de melhores condições de vida e de apoio no cuidado e educação de seus filhos. A falta do atendimento em período integral também contribui com tal fenômeno. Para famílias que permanecem no campo, notamos que uma das alternativas tem sido o abandono do trabalho no âmbito extradoméstico pela mulher, para que possa cuidar e educar suas crianças - em período integral ou meio período, a depender da idade - o que pode contribuir para a desigualdade de gênero entre homens e mulheres nos territórios rurais. Conforme afirmou Adriana, que manifestou na entrevista o desejo de trabalhar no ambiente extradoméstico, “... Lá na cidade, eu falo pro meu marido, que lá na cidade se a gente quiser trabalhar, tem alguém que olhe os filhos, né? Tem uma escolinha, a gente arruma alguém, paga. Na roça não tem, né? Todo mundo tem seu serviço pra fazer (...) Não tem outra opção, né? (...) Aí geralmente, como essas mulheres daqui não têm alguém que olhe os filhos, então elas preferem fazer doce, queijo, esses trem e revender, né?...”. A ausência de serviços públicos de Educação Infantil nos territórios rurais parece atravessar o cotidiano e a dinâmica das famílias do campo. É importante salientar que todas as genitoras entrevistadas manifestaram o desejo de trabalhar no ambiente extradoméstico, conforme consta nos relatos a seguir:

“... Eu saí dia cinco de maio, foi o dia que eu fui na empresa pra acertar. Ai ela [Íris] estava com sete meses (...) Eu até que gostaria de ter continuado, mas como lá dentro eles não liberava a gente pra ir olhar as criança, né? Minha mãe que olhava [irmãos de Íris]. E na época quando eu engravidei, eu tenho uma irmã solteira que engravidou também, morava com a minha mãe, né? Então como eu ia 
tirar a minha mãe de dentro de casa pra olhar o menino dela, porque é um menino o dela... Ela ia pra minha casa olhar o meu, sendo que a outra irmã minha tinha o menino da mesma idade que precisava também? E ela também trabalhava. Ai eu conversei com o meu esposo. 'Não, então... você sai do serviço'...". (Genitora Irene)

“... E vontade de trabalhar eu tenho muito, mas só que aqui não tem condução pra mim trabalhar e voltar... porque é longe... Olha como que é! Não passa nenhum ônibus aqui perto pra mim pegar, se eu for ter que pegar um ônibus pra ir pra cidade eu tenho que ir lá pra Escola, pra de lá eu pegar um ônibus lá pra mim ir pra cidade (...) É longe e fica ruim pra mim trabalhar e ter que arrumar os meninos pra ir pra Escola, tem que fazer comida (...) Trabalhar fica muito difícil, mas eu tenho vontade de trabalhar... Ichi!!! Lá na Bahia eu trabalhava, ficava parada não (...) Era na cidade. Era pequena, mas era uma cidadinha, nós trabalhava direto...". (Genitora Flaviana)

“... É, tem 6 meses que a gente mudou pra cá (...) É eu trabalhava em casa e fazia faxina pra fora (...) $E$, aqui eu, eles, meu cunhado queria que eu fizesse queijo, só que eu não gosto desse trem não (...) É, queijo pra vender, esse trem, doce, eu falei: 'Não, não gosto de mexer com isso não' (...) Até inclusive eu falei que ia no mês que vem, né? Eu ia voltar lá pra cidade, aí eu estou assim: não sei se eu vou, não sei se eu fico (...) É levar meus trem e ficar de mudança lá, chegar lá, arrumar um serviço, e arrumar uma Escola pros meninos, só que eu tô pensando ainda se eu vou ou não (...) Eu tenho vontade de trabalhar fora...". (Genitora Adriana)

Notamos como a ausência de Educação Infantil no campo e em período integral, por vezes, faz com que a mulher permaneça no ambiente doméstico, muitas vezes contra o seu desejo. Diante de tais condições de vida e de trabalho, Adriana mencionou que cogitava, inclusive, a possibilidade de voltar para a cidade com os filhos, “... Eu ia voltar lá pra cidade (...) Levar meus trem e ficar de mudança lá, chegar lá, arrumar um serviço...".

Nesse cenário, famílias entrevistadas indicaram a necessidade de haver no campo instituições de Educação Infantil, e em período integral, para atender às famílias rurais, principalmente aquelas cujas genitoras desejam/precisam trabalhar ou trabalham no âmbito extradoméstico:

“... Aqui no campo deveria sim ter, porque na cidade tem, né? Assim, tem assim escolinha (...) Igual, se eu tivesse quem olhasse meus meninos, eu já estaria trabalhando, né? Igual tem muitas crianças, às vezes que é pequeninha, a mãe quer trabalhar e não tem como, né? Se tivesse uma escolinha, alguma coisa, né?(...) Poderia pôr e trabalhar, né? Igual na cidade (...) A Bete mesmo falou que o rapaz do posto falou que arruma um serviço pra ela, mas ela não tem como deixar os meninos, né? (...) [Na Escola Flamboyant é] Só meio período. Como é que você faz com meio período, né? (...) Não tem como...". (Genitora Adriana)

“... Eu acho que [a Escola Flamboyant] teria que receber a partir de 4 anos, igual a Escola que tem lá no Bairro Jardim Paranaíba [na cidade] recebe de 4 anos (...) Sabe? Então, quer dizer, está certo que não vai ser uma obrigação muito severa mas a criança já vai se adaptando melhor à Escola, né?, de 4 anos (...) Então fica sendo tipo assim um jardinzinho mesmo assim, uma coisa assim tal... Eu não entendo porque que lá aceita até de 4 anos e aqui não, sendo que é Escola municipal do mesmo jeito, mesma coisa (...) Eu, então, pra mim todas Escolas municipais teriam que receber criança... Se uma recebe de 4 anos, todas têm que receber (...) Mas, por exemplo, se for só as particular que recebesse 
de 4 anos e as municipal não, aí sim, aí justifica. De uma não ter... E a outra ter. Agora uma ter e a outra não ter, não justifica... Vai justificar o quê? E eu tenho certeza que se eles abrir ali vai ter criança pra isso...". (Genitora Inês)

“... Ah, eu acho que deveria ter sim, na zona rural. Tipo assim, perto da Escola ter uma Creche (...) Pra atender a criança porque se a Escola só pega de 5 pra cima ter... igual o EMEI [na cidade]. É. O EMEI parece que pega de 0 a 5 anos só, né? Mas o EMEI parece que ele trabalha paralelo à Escola, uma coisa assim, não é?(...) Então, então eu acho que deveria ter sim mais uma escolinha, uma Creche que atenda essas, essas mães principalmente mães que moram em fazendas assim, que às vezes trabalha também...”. (Genitora Inês)

Nos relatos apresentados, evidenciamos que as entrevistadas defenderam a ideia de que deve haver Creches e Pré-escolas nos territórios rurais, possibilitando o trabalho de ambos os genitores no âmbito extradoméstico. Percebemos que a questão do acesso à Educação Infantil parece se relacionar também com a ideia de que deve existir uma igualdade de direitos e oportunidades entre campo e cidade, sendo a precariedade do acesso à Educação existente no campo questionada pelas famílias do campo.

No que tange à Creche no meio rural, Fabíola defendeu, porém, que o oferecimento deste serviço deveria estar atrelado à existência de uma demanda “... igual tem pra Escola...” e pareceu se ancorar em parâmetros quantitativos, de custo x benefício, para se pensar na viabilidade do atendimento no campo, “... Eu acho que se tivesse seria bem melhor, mais fácil, né?, pro pessoal da zona rural também (...) Não, não acho que tem que ter não, se tivesse eu acho que facilitaria, mas se for o caso atrapalhar pra Prefeitura também, né? Tem que ver se tem demanda também, né?...”.

Outra entrevistada defendeu, ainda, a ideia de que atendimentos informais para atender criança de 0 a 3 anos poderiam ser estruturados, apontando/criticando a existência da legislação que estabelece critérios para funcionamento de Creches no Brasil: “... Eu mesmo amaria, eu teria vontade de abrir uma... uma coisa mas hoje em dia pra você abrir uma Creche, você tem que ser pedagoga, você tem que ser mais não sei o quê e eu acho que o que mais você vê por aí é crianças morrendo dentro de Creche, criança sendo espancada dentro de Creche, mais não sei o quê dentro de Creches que tem pedagogo (...) mas falta o principal que é o amor pela criança..." (Genitora Inês). Nesta fala, notamos que a entrevistada pareceu vincular-se à concepção de que o atendimento das crianças de 0 a 3 anos seria mais assistencial e afetivo do que educacional, o que não exigiria formação superior dos profissionais envolvidos.

A nosso ver, as famílias do campo parecem defender a Pré-escola como direito da criança e da família, devendo ser garantida pelo Poder Público. No entanto, quando está em 
pauta a Creche, as famílias parecem flexibilizar suas exigências, refletindo, inclusive, sobre a possibilidade de informalidade no atendimento e sua realização por profissionais com menor formação profissional.

Sobre a importância de ser oferecida a Pré-escola no campo, uma das famílias teceu algumas considerações sobre o atendimento já existente na Escola Flamboyant:

“... Se não fosse pra ele ir pra ali ia ser muito difícil eu pagar pra ele ir pra cidade. Porque aí não tinha outra solução. Pra você ver, a gente ganha pouco, eu tenho ajuda dos meus pais pra criar ele, $e$ estou vivendo da pensão do pai dele agora, né?, mas é pouca coisa, não é grande coisa... Pra pagar pra ir pra outro lugar ia ser mais difícil. E ali pelo menos a gente tem que agradecer de ter de graça, né? Você pagando, não, acho que você está pagando em alguma coisa que você paga imposto, mas ali mesmo eles não cobra nada da gente, então acho que isso é uma vantagem, porque senão ia ter até mesmo que ficar fora da Escola, né?, não só o Fabrício como todas as crianças aqui da fazenda, então isso pra mim é uma vantagem...". (Genitora Fabiola)

“... Mas eu acho muito importante [ter Escola para as crianças de 5 anos], porque tem muita Escola no campo, na minha regra - que eu acho, né? - que não teria, né? Só tinha vaga, eu acho, que pra criança maior, né? Não tinha pra pequenininho, mas pelo menos nessa idade tem, né? Que quando eu vim pra cá, eu fiquei muito preocupada, eu falei assim 'Nossa, a gente... ', porque eu fiquei sabendo da Escola, ai eu pensei: 'Nossa, o Artur vai ficar sem estudar esse ano' (...) Ai depois eu fui lá na Escola. Aí a menina falou: 'Não, aqui tem vaga pra criança de 5 anos, o seu já tem 5?'. Eu falei: 'Tem' e falei 'Que beleza então que ele não vai ficar sem estudar, né?', mas aí já é importante ter pelo menos pra essa idade, né?(...) Porque aí eles não ficam sem estudar, né? Já vai conhecendo um pouco, né? Quando ele chegar na primeira série ele já está sabendo alguma coisinha, né? (...) Pra não, não ter, igual tem muitas crianças que já vai direto pra primeira série ou pra outra série, né? E assim, sem saber de nada, né? E eu acho que é importante já ir sabendo um pouquinho, né?...". (Genitora Adriana)

Conforme notamos nas falas apresentadas, Fabíola indicou que a existência de Educação Infantil na comunidade rural possibilitava o acesso das crianças do campo à Escola. Para Fabíola, tal acesso seria inviável para as crianças do campo se a Educação Infantil fosse oferecida somente na cidade, tendo em vista a ausência de recursos financeiros das famílias para custear o deslocamento das crianças. No mesmo sentido, Adriana afirmou a relevância de haver na Escola Flamboyant o atendimento das crianças de 5 anos. A Pré-escola, na visão da entrevistada, proporciona à criança aprendizagens relevantes para sua trajetória escolar. Ao falar sobre a Educação Infantil na Escola Flamboyant, a genitora mencionou ainda que outro elemento importante do atendimento no campo das crianças de 5 anos seria a facilidade de acesso à vaga em relação às instituições da cidade, “... Eu acho assim que a vantagem também é essa, né? Que no campo a gente consegue Escola, a vaga facinho pro filho da gente e eu acho que na cidade também poderia ser assim, né?...”. No entanto, ao contrário de Adriana, outras famílias indicaram que não havia o atendimento na Escola Flamboyant de todas as crianças de 5 anos cujas famílias demandavam vagas na instituição, “... E o dia que 
eu levei o Fabrício no primeiro dia da Escola eu vi mães com criança que precisava entrar com 5 anos também no segundo período e não conseguiu... teve que ficar na lista de espera...".

Apesar de ressaltar a importância do oferecimento da Educação Infantil para as crianças de 5 anos na Escola Flamboyant, famílias indicaram ainda em suas falas que tal atendimento nem sempre atendia às expectativas das famílias no que se refere à qualidade do serviço oferecido, no que tange à estrutura da Escola, ao transporte escolar, às atividades realizadas junto às crianças e à relação com as crianças e as famílias atendidas, conforme será mais bem discutido nos próximos subcapítulos deste trabalho.

A análise dos dados construídos pelas famílias indicou que as entrevistadas afirmaram que, na comunidade rural, existia demanda das famílias por Creche e Pré-escola no campo, e em período integral, e defenderam a necessidade de haver tais modalidades de educação no campo.

Ao discutirem a demanda pelas famílias do campo por Educação Infantil e opinarem sobre a necessidade de Creches e Pré-escolas na zona rural, notamos que as entrevistadas apontaram elementos que influenciariam a existência de tal demanda e, ainda, mencionaram critérios para avaliarem a necessidade de Educação Infantil no campo.

De acordo com as falas das famílias, intensificaria a demanda pela Creche e Pré-escola no campo elementos comuns, como a necessidade de trabalho dos pais. Tal elemento, que se relaciona com as condições materiais de vida e de trabalho das famílias do campo, se destacou nas falas das entrevistadas que apontaram dificuldades das famílias de conciliar o trabalho no campo e o cuidado e educação dos filhos. A demanda pela Pré-escola também seria intensificada, tendo em vista o desejo dos pais de que a criança pudesse realizar aprendizagens diferenciadas das que acontecem no ambiente familiar, o que indica como tais solicitações estariam relacionadas com as concepções dos mesmos sobre Educação Infantil e família. Tal complementaridade do cuidado e educação da criança entre instituições escolar e familiar foi defendida, pelas entrevistadas, como sendo ideal no caso de crianças da Préescola, mas não da Creche. Percebemos que houve um consenso, entre as entrevistadas, de que a família é o local mais adequado para a criança de 0 a 3 anos se desenvolver. Tal fato indica como as concepções sobre o desenvolvimento infantil, tendo em vista a faixa etária da criança, também podem influenciar a demanda pela Educação Infantil no campo, tornando-a mais intensa para a Pré-escola. Em síntese, percebemos que características das crianças e 
das famílias emergiram nas falas das famílias como elementos que influenciaram a demanda dos pais pela Creche e Pré-escola no campo.

Ao falarem sobre a existência da demanda por Pré-escola e Creche no campo, as entrevistadas foram indicando a precariedade do campo em relação à cidade no que tange ao acesso à Educação Infantil e, consequentemente, no que se refere às condições e vida e de trabalho das famílias do campo. Diante de tal precariedade, a permanência da mulher no âmbito doméstico é mencionada como alternativa encontrada pela família rural para cuidar e educar os filhos. A necessidade de haver Creche e Pré-escola no campo foi indicada, neste contexto, como meio de possibilitar o trabalho de ambos os genitores, garantindo a igualdade de gênero entre homens e mulheres do campo; permitir a permanência da família no campo; e garantir a igualdade de oportunidades para populações rurais e citadinas. As famílias do campo afirmaram ainda a necessidade de haver Pré-escola no campo como forma de possibilitar às crianças processos de aprendizagens. Notamos, dessa forma, que as famílias basearam-se na questão do direito da criança e da família, nas condições concretas de vida e de trabalho dos pais e em concepções sobre a Educação Infantil para avaliarem a necessidade de haver Educação Infantil no campo.

Para auxiliar na sistematização dos dados discutidos, construímos os quadros a seguir:

\begin{tabular}{|c|c|c|}
\hline Modalidade & \multicolumn{2}{|r|}{ Elementos que influenciam a demanda por EI } \\
\hline \multirow[t]{2}{*}{ Creche } & \multirow[t]{2}{*}{$\begin{array}{l}\text { Características das } \\
\text { crianças e famílias }\end{array}$} & $\begin{array}{l}\text { Faixa etária da criança associada às concepções de } \\
\text { desenvolvimento infantil: Famílias avaliam que o âmbito familiar é } \\
\text { o melhor local para o desenvolvimento da criança, o que atenua a } \\
\text { demanda. }\end{array}$ \\
\hline & & $\begin{array}{l}\text { Condições concretas de vida e de trabalho das famílias: Famílias } \\
\text { precisam deixar suas crianças na Escola para trabalhar e exercer } \\
\text { outras atividades, o que intensifica a demanda. }\end{array}$ \\
\hline \multirow[t]{2}{*}{ Pré-escola } & \multirow[t]{2}{*}{$\begin{array}{c}\text { Características das } \\
\text { famílias }\end{array}$} & $\begin{array}{l}\text { Condições concretas de vida e de trabalho das famílias: Famílias } \\
\text { precisam deixar suas crianças na Escola para trabalhar e exercer } \\
\text { outras atividades, o que intensifica a demanda. }\end{array}$ \\
\hline & & $\begin{array}{l}\text { Concepções sobre Educação Infantil: Desejam que seus filhos } \\
\text { ingressem na Escola para aprenderem, o que intensifica a demanda. }\end{array}$ \\
\hline
\end{tabular}

Quadro 15 - Elementos que influenciam a demanda por EI - Relatos das famílias 


\begin{tabular}{|c|c|c|}
\hline Modalidade & \multicolumn{2}{|c|}{ Critérios para avaliar a necessidade de EI no campo } \\
\hline \multirow[t]{2}{*}{ Creche } & $\begin{array}{l}\text { Direito da criança e } \\
\text { da família }\end{array}$ & $\begin{array}{l}\text { Necessária - Igualdade de direitos entre campo e cidade; Igualdade } \\
\text { de gênero. }\end{array}$ \\
\hline & $\begin{array}{l}\text { Condições concretas } \\
\text { de vida e de trabalho } \\
\text { das famílias }\end{array}$ & $\begin{array}{l}\text { Necessária - Famílias precisam deixar suas crianças na Escola para } \\
\text { trabalhar. Permite a permanência da família no campo. Evita } \\
\text { deslocamento para a cidade em busca da EI. }\end{array}$ \\
\hline \multirow[t]{3}{*}{ Pré-escola } & $\begin{array}{c}\text { Direito da criança e } \\
\text { da família }\end{array}$ & $\begin{array}{l}\text { Necessária - Igualdade de direitos entre campo e cidade; Igualdade } \\
\text { de gênero. }\end{array}$ \\
\hline & $\begin{array}{l}\text { Condições concretas } \\
\text { de vida e de trabalho } \\
\text { das famílias }\end{array}$ & $\begin{array}{l}\text { Necessária - Famílias precisam deixar suas crianças na Escola para } \\
\text { trabalhar. Permite a permanência da família no campo. Evita } \\
\text { deslocamento para a cidade em busca da EI. }\end{array}$ \\
\hline & $\begin{array}{l}\text { Concepções sobre } \\
\text { Educação Infantil }\end{array}$ & $\begin{array}{l}\text { Necessária - Importante para a aprendizagem e desenvolvimento da } \\
\text { criança. }\end{array}$ \\
\hline
\end{tabular}

Quadro 16 - Critérios para avaliar a necessidade de EI no campo - Relatos das famílias

\subsubsection{Aproximações e distanciamentos das significações das profissionais e das famílias sobre a (não) demanda de Educação Infantil no campo pelas famílias do campo}

As discussões realizadas acima evidenciaram que as significações construídas pelas profissionais de educação e pelas famílias rurais sobre a demanda da Educação Infantil no campo ora se aproximaram e ora se distanciaram.

No que se refere à questão da existência da demanda por vagas para a Educação Infantil no campo, percebemos que profissionais indicaram que a mesma existiria para crianças de 5 anos, ocorrendo, entretanto, menos solicitações de vagas para crianças de 0 a 4 anos e que não era avaliada como sendo uma demanda. Havia ainda um desconhecimento por parte de profissionais sobre a existência de demanda das famílias por vagas para suas crianças de 0 a 3 anos na Educação Infantil. Já as famílias do campo afirmaram que existia na comunidade demanda de pais por vagas em Creche e Pré-escola para suas crianças de 0 a 5 anos.

A existência da demanda pela Pré-escola no campo, nesse contexto, é mencionada tanto por profissionais como pelas famílias. No entanto, no que tange à Creche, um dado interessante foi que famílias (que residiam no campo quando seus filhos eram bebês) afirmaram que não desejaram colocar as crianças nesta instituição na idade de 0 a 3 anos, indicando o âmbito familiar como sendo local mais propício para o desenvolvimento dos filhos neste período. Tais famílias não demandaram vagas para Creche no campo, o que nos remete à afirmação de Rosemberg (2001) de que existem valores que medeiam a configuração de uma necessidade em demanda. Essa autora realiza críticas ao fato de que, por serem pobres, deduz-se com frequência que todas as famílias populares demandam vagas para seus 
filhos na Educação Infantil, o que pode não ser uma realidade, tendo em vista suas concepções, como foi constatado nesta pesquisa. A concepção da família como ambiente mais adequado para os bebês e da mãe como principal cuidadora - "antiga" historicamente, conforme mencionado no primeiro capítulo desta tese - e que vem sendo indicada por diversas pesquisas como ainda sendo fortemente defendida na atualidade por famílias brasileiras (VITORIA, 1997; DELGADO, 2005; LAVIOLA, 2010), foi evidenciada também no campo investigado.

É importante ressaltarmos que, apesar de famílias entrevistadas não terem demandado vagas para a Creche, percebemos que as mesmas indicaram que há na comunidade muitas famílias que demandam este serviço no campo, enquanto as profissionais afirmaram que chega à Escola uma tênue solicitação por Creche. Tal fato pode indicar a existência de uma demanda latente no âmbito rural por Creche e que não seria explícita e dimensionada pela lista de espera da Escola. Outro fato interessante evidenciado é que as poucas solicitações de vagas por Creche na Escola não eram avaliadas por profissionais como se constituindo como demanda das famílias, não sendo registradas pela Escola. A nosso ver, deparamos, neste caso, com outro tipo de demanda, além das demandas explícita e latente citadas por Rosemberg (2001). Pensamos que, na realidade investigada, existe ainda o que poderíamos chamar de demanda "silenciada", ou seja, que é manifestada pelas famílias na instituição escolar, mas que não é vista e registrada como demanda por Educação Infantil. Tal demanda parece surgir pelo fato de as profissionais se ancorarem em parâmetros urbanos (solicitações têm de ser "grandes" para se configurar como demanda), ao lidarem com a realidade (diferenciada) das comunidades rurais.

Percebemos que a demanda "silenciada" é, no contexto estudado, relativa à faixa etária de 0 a 4 anos. Pesquisadores vêm indicando como os bebês têm tido pouca visibilidade na ciência e nas políticas públicas (ROSEMBERG, 2002; LAVIOLA, 2010). Concepções das profissionais de educação sobre demanda podem contribuir ainda mais para manter os bebês do campo em tal posicionamento social.

Notamos, dessa forma, que significações das famílias e das profissionais sobre a existência de demanda por Educação Infantil no campo se diferenciaram e se aproximaram. Ao apreendermos dos relatos das profissionais e famílias elementos indicados pelas mesmas que influenciariam a demanda por Educação Infantil no campo, constatamos também semelhanças e diferenças em suas significações sobre a temática, conforme indica o quadro a seguir: 


\begin{tabular}{|c|c|c|c|}
\hline $\begin{array}{c}\text { Mod. } \\
\text { EI }\end{array}$ & $\begin{array}{c}\text { Elementos que } \\
\text { influenciam a } \\
\text { demanda por } E I\end{array}$ & Profissionais & Famílias \\
\hline \multirow[t]{4}{*}{ Creche } & \multirow[t]{3}{*}{$\begin{array}{c}\text { Características } \\
\text { das crianças e } \\
\text { famílias }\end{array}$} & $\begin{array}{l}\text { Faixa etária da criança associada à } \\
\text { necessidade de transporte escolar: } \\
\text { Famílias avaliam o transporte escolar } \\
\text { para as crianças pequenas como } \\
\text { sendo mais arriscado, o que atenua a } \\
\text { demanda. }\end{array}$ & --------------- \\
\hline & & & $\begin{array}{l}\text { Faixa etária da criança associada às } \\
\text { concepçôes de desenvolvimento } \\
\text { infantil: Famílias avaliam que o } \\
\text { âmbito familiar é o melhor local para } \\
\text { o desenvolvimento da criança, o que } \\
\text { atenua a demanda. }\end{array}$ \\
\hline & & & $\begin{array}{l}\text { Condições concretas de vida e de } \\
\text { trabalho das famílias: Famílias } \\
\text { precisam deixar suas crianças na } \\
\text { Escola para trabalhar e exercer outras } \\
\text { atividades, o que intensifica a } \\
\text { demanda. }\end{array}$ \\
\hline & $\begin{array}{l}\text { Características } \\
\text { do contexto rural }\end{array}$ & $\begin{array}{l}\text { Grande distância geográfica entre } \\
\text { Escola e família: torna o transporte } \\
\text { escolar mais arriscado para crianças } \\
\text { pequenas, o que atenua a demanda. }\end{array}$ & ( \\
\hline \multirow[t]{3}{*}{$\begin{array}{l}\text { Pré- } \\
\text { escola }\end{array}$} & \multirow[t]{2}{*}{$\begin{array}{l}\text { Características } \\
\text { das famílias }\end{array}$} & $\begin{array}{l}\text { Concepçôes sobre Educação Infantil: } \\
\text { Desejam que seus filhos ingressem na } \\
\text { Escola para aprenderem, o que } \\
\text { intensifica a demanda. }\end{array}$ & $\begin{array}{l}\text { Concepções sobre Educação Infantil: } \\
\text { Desejam que seus filhos ingressem na } \\
\text { Escola para aprenderem, o que } \\
\text { intensifica a demanda. }\end{array}$ \\
\hline & & $\begin{array}{l}\text { Condições concretas de vida e de } \\
\text { trabalho das famílias: Famílias } \\
\text { precisam deixar suas crianças na } \\
\text { Escola para trabalhar e exercer outras } \\
\text { atividades, o que intensifica a } \\
\text { demanda. }\end{array}$ & $\begin{array}{l}\text { Condições concretas de vida e de } \\
\text { trabalho das famílias: Famílias } \\
\text { precisam deixar suas crianças na } \\
\text { Escola para trabalhar e exercer outras } \\
\text { atividades, o que intensifica a } \\
\text { demanda. }\end{array}$ \\
\hline & $\begin{array}{l}\text { Características } \\
\text { do contexto } \\
\text { rural }\end{array}$ & $\begin{array}{l}\text { Oferecimento de trabalho no campo: } \\
\text { Maior em período de plantio e } \\
\text { colheita, o que permite a permanência } \\
\text { das famílias no contexto rural e } \\
\text { intensifica a demanda para a Pré- } \\
\text { escola. Menor em período de } \\
\text { entressafra, o que atenua a demanda. } \\
\text { Dinâmica da Reforma Agrária: } \\
\text { Venda de lotes de assentamentos } \\
\text { atenua a demanda. }\end{array}$ & 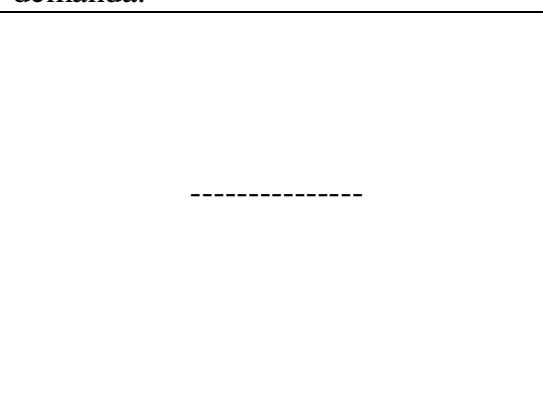 \\
\hline
\end{tabular}

Quadro 17 - Elementos que influenciam a demanda por EI - Relatos das profissionais e famílias

Profissionais e famílias afirmaram que há solicitações das famílias rurais por Préescola e Creche no campo. Alguns elementos que contribuiriam para a intensificação da demanda pela Pré-escola no campo foram indicados tanto por profissionais como pelas famílias, sendo os mesmos: as concepções das famílias de que a Pré-escola seria importante para o desenvolvimento do filho, o que faz com que as mesmas tenham o desejo de que a criança frequente a Escola; e a necessidade dos pais trabalharem. Profissionais afirmaram 
ainda que a possibilidade de as famílias trabalharem e, consequentemente, permanecerem no campo na época do plantio e da colheita também intensificaria a demanda pela Pré-escola. Já no período da entressafa, tal demanda se atenuaria. A mobilidade dos assentados também diminuiria a demanda pela Pré-escola no campo. Tais elementos não foram citados pelas famílias.

No que tange à Creche, profissionais e famílias mencionaram elementos diferenciados e que estariam relacionados com a demanda por este serviço. Para as profissionais, a demanda por vagas na Creche para as crianças de 0 a 3 anos era atenuada devido à necessidade do transporte escolar, tendo em vista a distância geográfica entre Escola e suas residências, o que seria mais delicado para crianças menores. Já as famílias mencionaram que não demandaram Creche para seus filhos quando estavam na idade de 0 a 3 anos, pois consideravam que a família seria o local mais propício para seus filhos se desenvolverem, devendo as crianças permanecerem exclusivamente junto à mesma neste período, o que contribuiria para reduzir a demanda por Creche. Famílias indicaram, porém, que a necessidade de famílias rurais trabalharem era um elemento, presente na comunidade, que intensificava a demanda dos pais por Creche.

Ao opinarem sobre a necessidade de haver Educação Infantil no campo, profissionais e famílias construíram significações que também se aproximaram e se distanciaram. Tanto profissionais como as famílias defenderam a necessidade de haver Pré-escola no campo. No entanto, no que se refere à Creche, houve divergências. Enquanto as famílias indicaram a necessidade de haver Creche na zona rural, houve profissionais que se aliaram a esta fala das famílias, mas outras que afirmaram a não necessidade de existir Creche nos territórios rurais. Os critérios utilizados para argumentarem sobre esta temática foram sistematizados no quadro a seguir: 


\begin{tabular}{|c|c|c|c|}
\hline $\begin{array}{c}\text { Mod. } \\
\text { EI }\end{array}$ & $\begin{array}{l}\text { Critérios para } \\
\text { avaliar a } \\
\text { necessidade de } \\
\text { EI no campo }\end{array}$ & Profissionais & Famílias \\
\hline \multirow[t]{4}{*}{ Creche } & $\begin{array}{l}\text { Direito da } \\
\text { criança e da } \\
\text { família }\end{array}$ & $\begin{array}{l}\text { Necessária - Igualdade de direitos } \\
\text { entre campo e cidade. }\end{array}$ & $\begin{array}{l}\text { Necessária - Igualdade de direitos } \\
\text { entre campo e cidade. } \\
\text { Igualdade de gênero. }\end{array}$ \\
\hline & \multirow[t]{2}{*}{$\begin{array}{c}\text { Condições } \\
\text { concretas de vida } \\
\text { e de trabalho das } \\
\text { famílias }\end{array}$} & $\begin{array}{l}\text { Necessária - Famílias precisam } \\
\text { deixar suas crianças na Escola para } \\
\text { trabalhar. Permite a permanência da } \\
\text { família no campo. Evita } \\
\text { deslocamento para a cidade em busca } \\
\text { da EI. }\end{array}$ & $\begin{array}{l}\text { Necessária - Famílias precisam } \\
\text { deixar suas crianças na Escola para } \\
\text { trabalhar. Permite a permanência da } \\
\text { família no campo. Evita } \\
\text { deslocamento para a cidade em busca } \\
\text { da EI. }\end{array}$ \\
\hline & & $\begin{array}{l}\text { Desnecessária - Famílias não } \\
\text { precisam deixar suas crianças na } \\
\text { Escola para trabalhar. }\end{array}$ & \\
\hline & $\begin{array}{l}\text { Concepções } \\
\text { sobre } \\
\text { desenvolvimento } \\
\text { infantil e família }\end{array}$ & $\begin{array}{l}\text { Desnecessária - Família vista como } \\
\text { melhor local para o desenvolvimento } \\
\text { da criança. }\end{array}$ & \\
\hline \multirow[t]{3}{*}{$\begin{array}{c}\text { Pré- } \\
\text { escola }\end{array}$} & $\begin{array}{l}\text { Direito da } \\
\text { criança e da } \\
\text { família }\end{array}$ & $\begin{array}{l}\text { Necessária - Igualdade de direitos } \\
\text { entre campo e cidade. }\end{array}$ & $\begin{array}{l}\text { Necessária - Igualdade de direitos } \\
\text { entre campo e cidade. } \\
\text { Igualdade de gênero. }\end{array}$ \\
\hline & $\begin{array}{c}\text { Condições } \\
\text { concretas de vida } \\
\text { e de trabalho das } \\
\text { famílias }\end{array}$ & $\begin{array}{l}\text { Necessária - Famílias precisam } \\
\text { deixar suas crianças na Escola para } \\
\text { trabalhar. Permite a permanência da } \\
\text { família no campo. Evita } \\
\text { deslocamento para a cidade em busca } \\
\text { da EI. }\end{array}$ & $\begin{array}{l}\text { Necessária - Famílias precisam } \\
\text { deixar suas crianças na Escola para } \\
\text { trabalhar. Permite a permanência da } \\
\text { família no campo. Evita } \\
\text { deslocamento para a cidade em busca } \\
\text { da EI. }\end{array}$ \\
\hline & $\begin{array}{l}\text { Concepções } \\
\text { sobre Educação } \\
\text { Infantil }\end{array}$ & $\begin{array}{l}\text { Necessária - Importante para a } \\
\text { aprendizagem e desenvolvimento da } \\
\text { criança. }\end{array}$ & $\begin{array}{l}\text { Necessária - Importante para a } \\
\text { aprendizagem e desenvolvimento da } \\
\text { criança. }\end{array}$ \\
\hline
\end{tabular}

Ao afirmarem a necessidade da Creche e Pré-escola no campo, profissionais e famílias foram evidenciando a utilização de critérios semelhantes para manifestarem tal opinião, sendo os mesmos: a necessidade de as famílias trabalharem e contarem com a Educação Infantil para complementar o cuidado e educação dos filhos, permitindo a permanência da família no campo; e a necessidade de garantir uma igualdade de direitos entre campo e cidade. Tanto famílias como profissionais descreveram o campo como sendo carente, precário no que tange ao acesso a uma Educação de qualidade em relação aos centros urbanos. A Educação Infantil como sendo um direito também das populações do campo foi defendida.

Para as famílias, tal acesso à Creche e à Pré-escola, e em período integral, possibilitaria ainda às mulheres trabalharem no âmbito extradoméstico, contribuindo para uma igualdade de gênero no campo. Tal elemento parece emergir nas falas das famílias como sendo importante, tendo em vista suas próprias experiências no campo, já que, nas suas falas, 
fica evidenciada a busca das entrevistadas em conciliar suas atividades como mães e trabalhadoras, diante das condições de vida e de Educação na zona rural. É importante salientarmos que tal desejo de trabalhar no âmbito extradoméstico é indicado por genitoras quando seus filhos estavam na faixa etária da Pré-escola, já que, ancoradas na concepção de que a família seria o melhor local para seus filhos se desenvolverem de 0 a 3 anos, indicaram que optaram por ficar com os mesmos nesse período (famílias que residiam no meio rural nessa época). A discussão da Educação Infantil atrelada à questão de gênero não foi diretamente mencionada pelas profissionais.

Apesar de indicarem que não demandaram Creche no campo para seus filhos de 0 a 3 anos, ao serem questionadas sobre a necessidade de Creche na zona rural, famílias rurais foram enfáticas em afirmar a precisão desta instituição no campo, não só pela perspectiva dos direitos das crianças e das famílias à Educação, mas também pela necessidade de pais do campo trabalharem. Famílias entrevistadas, baseando-se na vivência em suas comunidades, relataram dificuldades enfrentadas por muitos pais que precisam trabalhar para se sustentarem, mesmo quando seus filhos são bebês e que, diante da falta de Creche no campo, passam por dificuldades, sendo forçadas a buscar outros contextos para seus filhos serem cuidados e educados - como nas residências de mulheres que tomam conta de crianças (mantendo práticas antigas historicamente junto à infância, conforme discutido no capítulo 1) - ou ainda, tendo de mudar do campo para a cidade em busca de melhores condições de vida.

Algumas profissionais aliaram-se às falas das famílias sobre a necessidade de Creche na zona rural, tendo em vista a necessidade de trabalho dos pais. No entanto, outras profissionais afastaram-se de tais significações, afirmando não ser necessária Creche no campo. Para justificar esta opinião, uma das profissionais pontuou que a Creche não seria necessária no campo já que seria melhor as crianças permanecerem sob os cuidados das famílias nesta faixa etária e, ainda, pelo fato de as famílias trabalharem nas suas residências. Sobre este segundo argumento, percebemos que o mesmo indica a precariedade de conhecimentos mais aprofundados da profissional sobre as diversidades de condições de vida e de trabalho daquelas famílias atendidas pela Escola, tendo em vista que muitas delas exerciam atividades profissionais em agroindústrias da região e não na agricultura familiar. Nas famílias que participaram da pesquisa, percebemos que as genitoras trabalhavam no ambiente doméstico. Porém, enquanto a profissional afirmou que a Creche seria dispensável, pois as mães do campo trabalham em casa, uma das famílias indicou que mães do campo muitas vezes são obrigadas a trabalhar nas suas residências, em afazeres domésticos (cuidado 
com as crianças e com a casa) justamente pela falta de Educação Infantil em período integral e no campo.

Um dado importante constatado sobre essa temática é que, para as genitoras, as possibilidades de realização de serviços diferenciados dos afazeres domésticos parecem ser vislumbradas no ambiente extradoméstico. Não constatamos a referência, pelas mães, sobre a possibilidade e/ou consecução de atividades no âmbito de suas residências e voltadas, por exemplo, à agricultura familiar, cuidado com os animais, dentre outras. A demanda pela Educação Infantil e em período integral pelas famílias, no contexto investigado, relaciona-se com o desejo de realização de trabalho assalariado, não relacionado, portanto, com o trabalho direto na e com a terra. Na nossa investigação, o trabalho no campo aparece fortemente vinculado à prestação de serviços, em indústrias e em fazendas. $\mathrm{Na}$ época da pesquisa, os genitores de quatro das cinco famílias participantes do estudo prestavam tais serviços no campo, sendo que um dos genitores trabalhava como motorista em uma Empresa de transporte, enquanto as mães dedicavam-se ao cuidado e à educação dos filhos e aos afazeres domésticos.

No que tange à Pré-escola, tanto profissionais quanto as famílias afirmaram a necessidade de a mesma ser oferecida no campo a fim de possibilitar processos de aprendizagem e desenvolvimento à criança.

A partir das discussões realizadas acima evidenciamos que as significações das profissionais ora se aproximaram e ora se distanciaram das concepções das famílias do campo relativas à demanda. Nos relatos das famílias e profissionais, pudemos apreender que, ao falarem sobre a existência de demanda por Educação Infantil no campo, indicarem elementos envolvidos na existência desta demanda e apontarem critérios utilizados para avaliarem a (não)necessidade da Educação Infantil no âmbito rural, houve a construção de diferentes significações quando estava em pauta as crianças de 0 a 3 anos e as crianças de 4 e 5 anos. Evidenciamos que a faixa etária das crianças se constituiu como importante circunscritor no processo de construção de significações das profissionais e famílias sobre a Educação Infantil no campo.

Outro dado observado na discussão da demanda por Educação Infantil no campo foi o de que os movimentos de aproximações e distanciamentos das significações das famílias e de profissionais sobre a temática deste subcapítulo parecem ser influenciados pela forma como estabelecem diálogos com elementos da matriz sócio-histórica (e urbanos) e com elementos 
do campo, da concretude dos territórios rurais. Tais movimentos de aproximações e distanciamentos são indicados nas figuras a seguir:

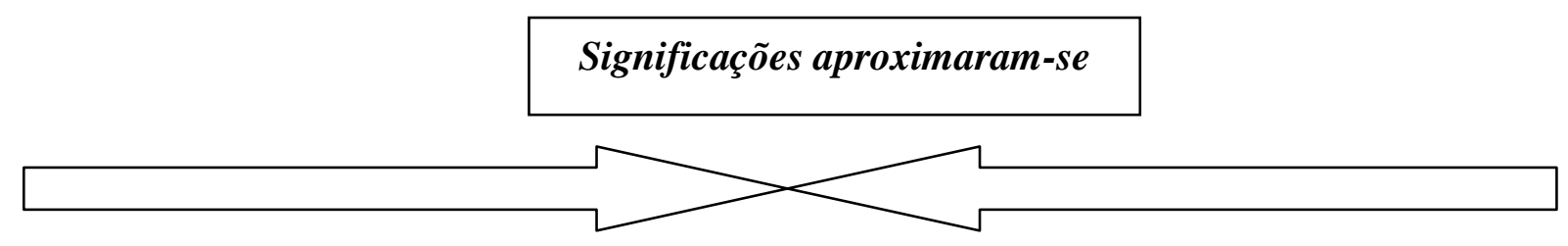

- A aproximação das significações das profissionais em relação às significações das famílias pareceu se relacionar com momentos em que dialogam:

- Com elementos da matriz sócio-histórica. Exemplos: Defenderam a Creche e a Préescola como direito da criança e família do campo. Conceberam a Pré-escola como sendo importante para o desenvolvimento da criança.

- Com a realidade concreta do campo e das famílias do campo. Neste caso, evidenciamos a existência de conhecimentos dos profissionais de educação sobre o contexto rural no qual as crianças vivem. Exemplos: Avaliaram que a demanda por Educação Infantil no campo ocorria devido ao desejo das famílias de que seus filhos ingressem na Escola para aprenderem. Avaliaram que há demanda pela Pré-escola no campo e conceberam a Creche e a Pré-escola importantes no âmbito rural, tendo em vista a necessidade de os pais trabalharem. Indicaram que a Educação Infantil no campo é necessária para possibilitar a permanência das famílias no campo.

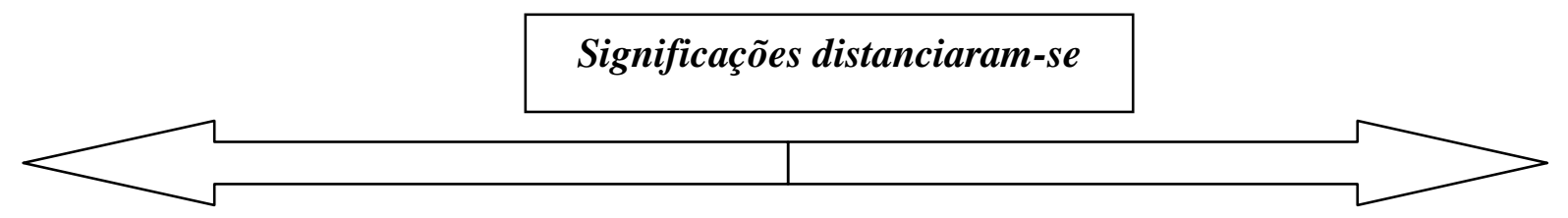

- O distanciamento das significações das profissionais em relação às significações das famílias pareceu se relacionar com um afastamento das profissionais de características do contexto rural e da realidade, desejos, concepções e necessidades das famílias atendidas. Exemplos: Profissionais não avaliaram as poucas solicitações de vagas em Creche no campo como sendo demanda, enquanto as famílias mencionam que existe uma demanda no campo por Creche. Profissionais afirmaram a não necessidade de Creche no campo devido ao fato da mulher trabalhar na sua residência, já as famílias indicaram a necessidade de Creche na zona rural justamente para possibilitar a mulher trabalhar fora do âmbito doméstico e mencionaram a importância da Educação Infantil como forma de igualdade de gênero no campo. 
Dessa forma, evidenciamos que, nos momentos em que há um distanciamento das significações das profissionais e das famílias sobre a temática da demanda no campo por Educação Infantil, as famílias parecem se ancorar mais na concretude dos contextos que vivem para a construção de suas significações, enquanto as profissionais parecem se ancorar mais em concepções gerais sobre famílias do campo e Educação Infantil e vinculadas ao mundo urbano, indicando a precariedade de conhecimentos sobre as famílias atendidas. Já nos momentos em que há uma aproximação das significações das profissionais e famílias percebemos que as entrevistadas parecem dialogar com elementos mais gerais da matriz sócio-histórica (como concepções sobre a Pré-escola, desenvolvimento infantil, dentre outras) e com a concretude do contexto rural no qual se encontram. 


\subsection{OBJETIVOS DA EDUCAÇÃO INFANTIL NO CAMPO PARA AS CRIANÇAS/ FAMÍLIAS DO CAMPO}

\subsubsection{Significações das profissionais sobre objetivos da Educação Infantil no campo para as crianças/famílias do campo}

Ao longo das entrevistas com profissionais da Escola Flamboyant foram questionados, às participantes da pesquisa, quais seriam os objetivos da Educação Infantil. No que tange aos objetivos da Educação Infantil para a criança, profissionais afirmaram:

“... Começam assim, a socialização, o conhecimento geral das coisas...”. (Profissional Vivian)

“... Você vai trabalhar essa parte de socialização, aí é onde você vai desenvolver a parte motora conjunta, e também em conjunto com a parte intelectual, afetiva (...) [Nós realizamos atividades] visando à formação total do ser humano, onde vai trabalhar esses quatro aspectos que eu te falei: o cognitivo, o afetivo, o social e o motor...". (Profissional Paula)

Notamos que Vivian afirmou que a Educação Infantil tem como objetivo possibilitar à criança processos de aprendizagens e de socialização. No mesmo sentido, Paula pontuou que a Educação Infantil possui como meta promover a socialização da criança indicando o desenvolvimento social como estando interligado ao desenvolvimento motor, afetivo e cognitivo. A concepção de que a Educação Infantil deve promover o desenvolvimento integral da criança foi defendida neste cenário.

Sobre a questão da socialização da criança, profissionais afirmaram ainda:

“... Hoje quando você fala pra mim assim, 'Qual a vantagem da criança entrar na Escola mais cedo?'. A vantagem é que ela primeiro vai aprender a socializar com outras crianças (...) Aprender a troca, a dividir, sabe?, a conviver com outras crianças. Então aquele impacto que ela teria que ter mais tarde, ela vai ter mais cedo...". (Profissional Patrícia)

“... [A criança] vai entrar também no primeiro ano com uma base assim, até regrinhas de convivência, né?, regrinhas básicas pra ele vai ser melhor, né? (...) Educação Infantil, essas coisas pros da cidade é normal e pros nossos aqui também acho que acaba sendo as vantagens, né?, de socialização total com eles, né?...”. (Profissional Vivian)

As profissionais indicaram que a socialização da criança, a interação da criança com seus pares e os processos de aprendizagem ocorridos na Educação Infantil seriam importantes para a criança, seja ela residente no campo ou na cidade. Vilma apontou que a ida da criança 
para a instituição de Educação Infantil e o processo de socialização que ocorreriam neste contexto seriam relevantes para a criança, tendo em vista as configurações de famílias atendidas, “... muito dessas crianças (...) ou ele é um filho único, ou ele é um filho temporão...".

Além da questão da socialização e interação com outras crianças, as profissionais relataram ainda que a Educação Infantil tem outras finalidades, conforme pode ser observado nos relatos abaixo:

“... Trabalha-se [na Educação Infantil] a questão das atividades de lateralidade, né? Trabalha... é... a histo... a história de vida, né? Que é todo o trabalho feito com o nome da criança. Trabalha esse... é... contagem, identificação de... de objetos. Trabalha-se também a questão dos cinco sentidos, pras crianças... É... Trabalha-se também aquela questão de... é... princípios de higiene, é... princípios de comportamento, de disciplina...". (Profissional Vilma)

“... A criança que faz a Educação Infantil, a gente nota a diferença quando ela passa pro Fundamental, do que aquela que vai direto pro Fundamental (...) [A diferença é] Muita, gritante, o aluninho que vem cruzim pro primeiro ano, do que passa pela Educação Infantil, é totalmente diferente, ele já vem com cores, né? Com habilidade com lápis, ele já é uma criança bem... é... mais... É desprendida dos pais assim, então já vem (...) a Educação Infantil é uma base pra criança, pra vida escolar dela, nossa...”. (Profissional Dirce)

“... [O objetivo da EI é] Preparar as crianças pra o Ensino Fundamental (...) A gente desde o berçário, a gente trabalha com eles no berçário, a gente estimula eles com objetos coloridos, eles já vão conhecendo as cores, eles não sabem te falar, mas a gente já percebe qual a cor que ele gosta mais, é... musicalização (...) É, não é só a questão do aprender a escrever. A gente vai trabalhando a coordenação motora deles, começa na coordenação motora grossa que é andar, correr, pular até eles chegarem na coordenação motora fina que é o conseguir pegar o lápis, escrever...". (Profissional Poliana)

As entrevistadas apontaram que a frequência da criança na Educação Infantil se constituiria como preparação para o Ensino Fundamental, na medida em que possibilita diferentes aprendizagens para a criança, diversos processos de desenvolvimento e faz com que a criança se adapte, em momento anterior ao ingresso no Ensino Fundamental, à questão do distanciamento da família no período em que está na Escola, “... ele já é uma criança bem... é... mais... É desprendida dos pais...".

$\mathrm{Na}$ fala de Poliana, notamos ainda que a profissional abordou a temática da alfabetização da criança, pontuando que a Educação Infantil não teria como meta somente “... a questão do aprender a escrever...". No que tange à alfabetização da criança na Educação Infantil, profissionais afirmaram: 
“... A gente trabalha mais o lúdico, né? Não no intuito de alfabetizar, não é esse o intuito da Educação Infantil, né? Sair menino lendo e escrevendo... nunca, né?, é esse o intuito, mas é mesmo acho que do desenvolvimento psicomotor, tudo da criança, nessa faixa etária, não focando na alfabetização não (...) Trabalha mais no concreto, né? (...) O foco não é alfabetizar não, é só o menino subir de nível e nesses níveis silábicos e pré-silábicos tem os conteúdos que são ministrados, as atividades que são ministradas pra criança ir avançando de nivel, né?... '. (Profissional Dirce)

“... Aqui, a gente puxa mais um pouquinho porque não é visado mais a Educação Infantil a alfabetização, né?, eles não visam mais (...) Eles acham que isso aí é deixa pro fundamental, tanto é que eles tiraram o pré da Educação Infantil e virou o primeiro ano porque, o primeiro ano já é visando à alfabetização do aluno...”." (Profissional Vivian)

Notamos que Dirce indicou que a Educação Infantil tem como objetivo a realização de atividades lúdicas que proporcionam o desenvolvimento psicomotor e da escrita. A entrevistada pontuou ainda que a Educação Infantil não tem como meta alfabetizar. No entanto, Vivian indicou que a Escola Flamboyant vinha desenvolvendo um trabalho voltado para a alfabetização da criança, “... aqui, a gente puxa mais um pouquinho...”. Sobre esta temática, Poliana pontuou:

“... É que a gente que trabalha, eu trabalho na Educação Infantil muito com o lúdico. É o que está sendo jogado pelo município hoje, pra dar um enfoque mais no lúdico (...) E ela [professora da EI] trabalhava mais com o registro (...) O registro é a folha, o papel e fazer tudo no papel (...) A gente trabalha mais na Educação Infantil o enfoque maior é o concreto, aquilo que você pega. E o dela é mais o papel...". (Profissional Poliana)

“... O que eu achei de diferente é porque a professora que atuava [na Educação Infantil] com eles trabalhava seguindo as regras do fundamental (...) conforme o Ensino Fundamental. Pelo o que eu observei das atividades que eu peguei os cadernos deles pra tá dando uma olhada, ela trabalhava bem o ensino tradicional com eles, que é o de cópia, ela estava praticamente alfabetizando eles (...) Assim, a gente alfabetiza também nesta idade, mas o objetivo dos cinco anos que é passado pra gente nos cursos da Educação Infantil é que os cinco anos o objetivo é eles conhecerem o alfabeto, conseguir escrever as letras do alfabeto, não são todos que conseguem, mas a maioria sai conseguindo o nome completo no final do ano e as noções de matemática que é cores, quantidade (...) tudo isso que é o trabalhado na Educação Infantil, e ela já estava indo além disso (...) E pelo que eu percebi a maioria não estava conseguindo acompanhar...”. (Profissional Poliana)

Nos relatos acima, Poliana teceu críticas à forma como o trabalho na sala de Educação Infantil vinha se desenvolvendo na Escola Flamboyant. De acordo com a entrevistada, tal trabalho seguia princípios do Ensino Fundamental, sendo as atividades da Educação Infantil voltadas para a alfabetização e realizadas dentro de uma perspectiva tradicional de ensino. Atividades lúdicas com materiais concretos - para aprendizagens como o conhecimento do alfabeto e de matemática -, e planejadas conforme os princípios da Educação Infantil, não estariam sendo realizadas. Poliana mencionou ainda que, a seu ver, as crianças não estariam 
conseguindo realizar as atividades propostas na sala de Educação Infantil e que visavam à alfabetização.

O fato de a Educação Infantil seguir princípios e metas do Ensino Fundamental parece ser evidenciado ainda por outras entrevistadas que indicaram em suas falas uma preocupação de preparar as crianças da Educação Infantil para que conseguissem obter resultados favoráveis nas avaliações realizadas no Ensino Fundamental pelo Governo:

“... Então o objetivo [da Escola] é sempre, o foco é o quê? O foco é o quê? É trabalhar mais, pra fazer com que os alunos aprendam mais e o rendimento da Escola seja maior [nas avaliações realizadas da Escola pelo Estado]...". (Profissional Vivian)

“... A gente é cobrado pelas... pelas provas sistêmicas, né? que... que a gente tem que fazer durante o ano. Cada ano é avaliado duas séries na Escola. Então a gente tem que tá preocupado com isso porque todas as verbas que a gente recebe é em cima do... desse aumento de... do aumento de qualificação que essas crianças têm. De qualidade de ensino (...) Se nós estamos preparando eles [crianças da Educação Infantil], então eles vão ser futuros... futuros... nossos futuros alunos que vão nos ajudar nesse número... pra... número de qualidade pra aumento de verba (...) Então se a gente não fizer uma boa base (...) suponhamos que no próximo ano seja avaliado uma primeira série. Então aqueles alunos nossos que eram da Educação Infantil vão pra primeira série. Se eles não tiverem uma base, então eles não vão responder de acordo com aquilo que a gente está esperando...". (Profissional Vilma)

A defesa por uma Educação Infantil escolarizante e vinculada ao desempenho futuro da criança/às avaliações no e do Ensino Fundamental é realizada por entrevistadas. O entrelaçamento dos objetivos do Ensino Fundamental e da Educação Infantil parece ocorrer nesse contexto em que as avaliações das instituições escolares são colocadas em evidência e como algo que demanda a atenção da instituição. A ênfase no ensino de conteúdos como sendo o objetivo da Escola e da Educação Infantil é indicada em outros relatos, nos quais profissionais discutiram o (não) papel da Escola na educação da criança:

“... Existe a palavra ensinar e existe a palavra educar, antigamente o professor ensinava, hoje em dia o professor tá com a responsabilidade de educar, de educar... tem muitos pais que acha que é obrigação do professor da Escola, que é obrigação da Escola educar o filho dele (...) Sabe? Então esse conceito de ensinar e educar eu vejo assim... professora, a Escola em si nós estamos aqui pra que?, pra ensinar o aluno, pra ensinar. Hoje em dia a gente virou, a gente educa e ensina (...) Que normalmente educação vem de casa, a Escola é só o complemento, a Escola só complementa aquela educação, alguma coisinha assim que... muito pouco. Hoje em dia não... pai quer que a Escola educa, Escola tem obrigação. Igual a gente já ouviu muitas vezes o pai falar que a Escola não educa o filho dele, não temos que educar o filho dele, nós estamos aqui pra dar o quê? Pra ensinar ele, dar aprendizagem pra ele...". (Profissional Patrícia)

Notamos que a entrevistada defendeu a ideia de que não caberia à Escola/Educação Infantil a tarefa de educar a criança, mas sim de ensinar, "dar aprendizagem” para a criança, 
vista como um ser passível e não como construtora de conhecimentos. Em sua fala, notamos que às vezes a profissional mencionou que a Escola poderia complementar a educação da criança, no entanto, a mesma defendeu que tal função seria da família. Baseando-se nessa concepção, Patrícia realizou críticas às famílias que, de acordo com sua fala, solicitaria à Escola a educação da criança.

Sobre a questão do educar a criança na e pela Escola, Vivian pontuou:

“... Hoje, a Escola, educar, está sendo assim amplo, a gente está fazendo parte de tudo, entendeu? A Escola hoje ela é um pouco de tudo pro aluno, não adianta, tem gente que fala assim, 'Ah, mas a Escola não é lugar que a gente vai dar educação pro aluno isso traz de casa', mas eu não acho que seja isso, às vezes a minha vivência com aluno você vai estar ajudando, entendeu? (...) Sabe? Eu acho que é um envolvimento total Luciana, né? (...) E você tem que gostar, se você não gostar entendeu?, me dói quando eu vejo o pessoal falando assim, 'Ai, isso não é meu serviço, não é isso que eu tenho que fazer', entendeu? Então eu não vejo a coisa assim, eu acho que, se você pode fazer, porque não? Eu tô ali, 'Ah mas eu não ganho pra isso'. A gente não ganha por tanta coisa, né?...". (Profissional Vivian)

Percebemos que Vivian fez uma distinção entre o ensinar e o educar a criança, defendendo o pressuposto de que a Escola tem como meta ensinar a criança e complementar a família na tarefa de educá-la. Porém, a questão do complementar a família na educação da criança parece ser vista pela profissional não como sendo um objetivo da Escola/Educação Infantil, mas sim como sendo um favor, algo além do que lhe é atribuído como função. Em outros relatos, a profissional aliou-se à concepção de que a Educação Infantil complementaria a família na educação da criança em casos em que a família não consegue desempenhar tal papel adequadamente junto à criança, “... muita das vezes a mãe não consegue também educar ele direitinho, né?, a Escola acaba completando isso pros pais (...) É um complemento...".

Profissionais da educação, em seus relatos, mencionaram que a Escola/Educação Infantil oferece ainda à criança recursos importantes e às vezes diferenciados dos existentes na família do campo:

“... O espaço é muito grande, tem o parquinho pra eles brincarem, tem a piscina, apesar de não ter usado nem uma vez esse ano, porque chuva...”. (Profissional Patrícia)

“... Assim computador a maioria aqui é só aqui na Escola, né?, eles não têm computador (...) Não têm em casa, não é igual na cidade que tem, né? Aqui não, é só aqui...”. (Profissional Vivian)

No relato apresentado, Patrícia ressaltou que a ida da criança para a Educação Infantil possibilitaria que a mesma usufruísse um amplo espaço para seu desenvolvimento e que conta 
com estruturas importantes para a criança como piscina e parque infantil. Vivian apontou ainda como a inserção digital, que ocorreria na Escola Flamboyant, seria importante para a criança do campo, tendo em vista que o acesso à computação estaria restrito à instituição escolar, não estando presente nas residências das famílias do campo. De acordo com a entrevistada, tal fato se constituiria como um elemento positivo da ida da criança para a instituição escolar. A profissional ressaltou, porém, que tal acesso não teria a mesma qualidade existente na cidade, o que limitaria as possibilidades de aprendizagens da criança do campo relativas à informática, “... aqui a nossa internet é muito lenta (...) aqui se você colocar uma atividade de internet pra todo mundo, não aguenta, não dá conta (...) igual eu falei pra menina [no curso de formação para professores], falei 'Oh, eu nem fiz tanta questão de aprender blog, essas coisas porque a internet aqui... Não tem como'..." (Profissional Vivian).

Além de possibilitar o uso de diferentes espaços e recursos pelas crianças, profissionais indicaram ainda outros elementos que apontam para a importância e o intuito da Educação Infantil no campo para a criança e que, de acordo com as entrevistadas, justificaria inclusive a necessidade de o atendimento ser oferecido em período integral:

“... O ano que vem eles tão querendo começar a implantar a educação integral (...) Ah, eu acredito viu?, Luciana [que será oferecido para todas as crianças] (...) É, eu acredito que, assim, eu acho que tanta coisa que está acontecendo, que você acha que a única solução é a Escola, né?, quanto mais tempo o aluno ficar na Escola vai ser melhor, né? (...) Tanto problema que a gente vê,, né?, droga, é isso, é aquilo, então acho que eles pensa que o aluno estando na Escola vai evitar um pouco o problema, eu acredito, entendeu?...".

“... Apesar de que todas [famílias] aqui geralmente trabalham, se não é em casa, né?, se não é em casa é na granja, é em alguma coisa, mas eu acho que [o atendimento integral] é mais por causa da criança, a criança estar aqui, ela está menos vulnerável aos riscos que estão lá no meio que elas moram... por que o meio que ela mora é um lixo, é quase todas é um lixo, então aqui eles estariam mais em contato com um ambiente mais sadio, menos tempo lá onde eles ficam...".

As profissionais indicaram que a Educação Infantil é relevante para a criança na medida em que possibilita que a mesma permaneça menos tempo no ambiente familiar e comunitário, visto, pelas profissionais, como sendo problemático e inapropriado para a criança. A ideia da Educação Infantil como sendo uma substituta da família e como forma de solucionar problemas sociais é defendida nesse cenário. Ancorando-se nessa visão da família do campo, profissionais propuseram o atendimento integral da criança do campo na Educação Infantil, para a proteção da criança. Vale ressaltar que entrevistadas indicaram que a Educação Infantil deve proteger a criança, tanto dos riscos existentes nas famílias e comunidade como 
também no âmbito escolar - devendo, para tanto, oferecer estrutura apropriada e organizar adequadamente seus tempos e espaços -, conforme será mais bem discutido posteriormente.

A existência no campo de uma Educação Infantil com qualidade, segundo Paula, cumpriria ainda outros objetivos para a vida da criança, conforme indica o relato a seguir:

“... A Escola no caso vai servir como um direcionamento pra criança através de..., da realidade que ela vive, a gente procurar dar conhecimento e direcionar a vida dela para que ela tenha um futuro melhor do que esse que ela tá vivenciando aqui no campo (...) pra que no futuro ele se torne uma pessoa onde ela pode no caso, ter um futuro melhor, ter uma vida digna, uma... um trabalho mais valorizado, que a gente sabe que pessoas que tão na zona rural, dificilmente, a maioria chega a cursar uma faculdade, tem poucas familias aqui, no caso, que têm já uma certa estrutura, têm alguns casos de famílias que têm alunos aqui que são donos do lugar onde mora...". (Profissional Paula)

Paula indicou condições de Educação e de trabalho de populações do campo que, muitas vezes, não têm a possibilidade de ingressarem no Ensino Superior e de conseguirem colocações valorizadas no mercado de trabalho. A ideia de que a Educação no campo deve servir para que as crianças consigam melhorar suas condições de vida foi mencionada pela entrevistada. Para tanto, Paula pareceu aliar-se à concepção de que a Educação no campo deve estar atrelada à realidade das crianças do campo.

A partir das discussões realizadas acima, notamos que profissionais da educação mencionaram que a Educação Infantil no campo teria como objetivos promover a socialização da criança com seus pares e possibilitar processos de aprendizagem e desenvolvimento, ampliando as vivências da criança para além do âmbito familiar.

No que tange à questão da alfabetização da criança, percebemos que ocorreu a construção de significações diferenciadas pelas profissionais. Evidenciamos que houve entrevistadas que, apoiando-se em uma concepção mais escolarizante da Pré-escola, defenderam a ideia de que a Educação Infantil teria como meta alfabetizar, enquanto outras profissionais afirmaram que não caberia à Educação Infantil tal papel.

Diferentes significações também foram construídas no que se refere à questão da educação da criança na Escola. Enquanto algumas profissionais afirmaram que a instituição escolar não tem a função de educar a criança, outras profissionais indicaram que a Educação Infantil complementa a família na educação da criança. Uma das entrevistadas defendeu a concepção de que a Escola substituiria a família, vista como problemática e inadequada. 
Tais dados indicam a defesa, na Escola, de diferentes concepções sobre a Educação Infantil e seu papel frente ao Ensino Fundamental e às famílias atendidas. Parece existir, no âmbito escolar, uma indefinição e uma tensão relativa ao papel do Ensino Fundamental, ao papel da Educação Infantil e ao papel da família em relação ao cuidado e educação da criança. Por vezes, as significações construídas pelas profissionais sobre os objetivos da Educação Infantil se afastam dos preconizados pelas legislações nacionais em relação à criança (desenvolvimento integral, a partir da realização de atividades com enfoque no lúdico) e à família (complementá-la no cuidado e educação da criança).

Ao discutirem os objetivos da Educação Infantil no campo, profissionais defenderam ainda a ideia da Educação no campo como forma de ascensão social das crianças e famílias do campo, a partir da ampliação da escolaridade de seus membros. A concepção de que às crianças e às famílias do campo vêm sendo oferecidas oportunidades desiguais de vida é mencionada, havendo a defesa da Educação Infantil como forma de promover uma igualdade de direitos para populações rurais em relação às citadinas.

Para sistematizar os dados construídos nas entrevistas com profissionais sobre os objetivos da Educação Infantil no campo, apresentamos o quadro a seguir:

\section{Objetivos da Educação Infantil}

Possibilitar a socialização, a interação criança-criança

Possibilitar aprendizagens e desenvolvimento da criança, ampliando os que ocorrem na família Preparar a criança para Ensino Fundamental Alfabetizar Não alfabetizar Educar a criança Não educar a criança

Complementar a família no cuidado e educação da criança

Substituir a família no cuidado e educação da criança Melhorar condições de trabalho e de vida da criança e família

Quadro 19 - Objetivos da Educação Infantil - Relatos das profissionais 


\subsubsection{Significações das famílias sobre objetivos da Educação Infantil no campo para as crianças/famílias do campo}

Ao longo das entrevistas com as famílias do campo, houve o questionamento às mesmas sobre quais seriam os objetivos da Educação Infantil. No que tange a esta temática, as famílias afirmaram:

“... Bom o objetivo deles pra mim é ensinar, né? Porque... igual... tem criança que vai sabendo escrever o nominho e tudo bonitinho (...) A alfabetização começa agora, né?, e eles já começam ensinando...". (Genitora Irene).

“... Tipo assim... contar, né? (...) Fazer continha...”. (Genitora Adriana)

“... Eu pensava que já ia ensinar ele até escrever, mas o que eles ensinou esse ano foi escrever, que eu vi mais, foi ensinar a escrever as letras, né?, que ele já conhece todas as letras, os números, tudo ele aprendeu. Era mais ou menos isso mesmo que eu pensava que tinha que ser ensinado já pra ele ir conhecendo...". (Genitora Fabíola)

Notamos, nas falas apresentadas, que a questão do início da alfabetização e da aprendizagem matemática despontou nas falas das mães do campo, como sendo um dos objetivos da Educação Infantil. Fabíola indicou que sua expectativa era de que o filho seria alfabetizado, evidenciando uma distância entre o que a família esperava da Educação Infantil e o que foi realizado na Escola Flamboyant. A genitora de Flávio indicou, ao longo da entrevista, visões diferenciadas sobre o papel da Pré-escola na alfabetização da criança, ora afirmando que esta modalidade de educação tinha o intuito de “... ensinar a ler...”, e ora pontuando que a criança na Escola “... começa mesmo a pegar a ler e assim... depois dos seis anos pra cima. Os cinco anos eu acho que é mais pra brincar, pra poder ir desenvolvendo...”.

No que se refere aos processos de aprendizagem ocorridos na Educação Infantil, famílias defenderam a concepção de que os mesmos seriam relevantes, pois se constituiriam como uma preparação para o Ensino Fundamental: “... Já vai conhecendo um pouco, né? Quando ele chegar na primeira série ele já está sabendo alguma coisinha, né? (...) Pra não, não ter, igual tem muitas crianças que já vai direto pra primeira série ou pra outra série, né? E assim, sem saber de nada, né? E eu acho que é importante já ir sabendo um pouquinho, né?..." (Genitora Adriana). Outras entrevistadas indicaram ainda que a Pré-escola possibilitaria que a criança se adaptasse ao ambiente escolar em período anterior ao Ensino Fundamental: “... Foi com intuito mesmo, agora, desse ano, que ele entrou na Escola (...) enturmar com as outras crianças, ver o que que é a Escola, pro ano que vem já estar 
aprendendo, né?, Luciana, porque o ano que vem já vai começar mesmo (...) É o ano que vem já começa mesmo, né?, a estudar...” (Genitora Fabíola).

Além da questão da alfabetização da criança e de preparação para o Ensino Fundamental, famílias pontuaram que a Educação Infantil teria como meta possibilitar a interação criança-criança, sendo este um elemento importante para a matrícula dos filhos na Pré-escola, conforme consta nos trechos a seguir:

“... Eu levei ele [para a Escola Flamboyant] com esse intuito dele enturmar mesmo com as crianças, pra você ver, ele é criado sozinho, na minha família não tem crianças (...) O único coleguinha que ele tinha era esse que eu te falei o Túlio, às vezes uma ou outra criancinha que aparecia...". (Genitora Fabiola)

“... [Na Escola] ela tem mais coleguinhas, tem mais... porque se ela tivesse em casa era aqui, né? A família é os primos e tal... Pra ela conhecer pessoas diferentes, né? Convive com pessoas diferentes. Isso é muito bom, você conviver com pessoas diferentes (...) Você conviver com pessoas diferentes é bom desde criança, né? É bom pra aprender.Quando crescer já sabe como que é, né?..." (Genitora Irene)

Nos relatos apresentados, notamos que Fabíola indicou que a Educação Infantil possibilitaria a interação entre diferentes crianças, o que seria relevante para Fabrício devido à ausência de outras crianças no âmbito familiar e na vizinhança de sua residência, que pudessem interagir/brincar com o filho, o que era avaliado negativamente pela família. Contribuíam para tal fato - poucas possibilidades de interação criança-criança no âmbito familiar e comunitário - as características do campo onde a família morava, cujas residências eram distantes umas das outras. Nesse contexto, notamos como características de territórios rurais (distâncias geográficas) influenciam a dinâmica familiar e as expectativas de pais do campo no que tange à Educação Infantil.

No que se refere à questão da interação criança-criança na Educação Infantil, Adriana pontuou que a mesma seria importante para a criança, pois permitiria aprendizagens ligadas ao desenvolvimento da moralidade, “... Ah, às vezes é coisa é... a questão do respeito, né?(...) É... Saber dividir com o colega...”. Adriana afirmou ainda que a Educação Infantil teria um papel amplo no desenvolvimento e educação da criança:

“... Eles falam assim que a Escola e os pais têm que ser juntos, né? Então assim, a Escola ajuda também a gente, né? Com tudo, né? Questão de educação, com tudo (...) Às vezes, muitas vezes a gente fala uma coisa e tá errado, às vezes o professor fala e já tá certo, né?...". (Genitora Adriana)

Adriana indicou que a Educação Infantil teria como objetivo complementar a família no que tange à educação da criança, afirmando a necessidade de ambas as instituições - 
escolar e familiar - estarem próximas para a educação da criança. A genitora apontou que tal complementaridade pode gerar tensões na relação entre Educação Infantil e famílias na medida em que, por vezes, as falas da Escola são mais consideradas, ouvidas pela criança. Tal fato parece ser visto por Adriana como sendo uma forma de auxílio da Escola no processo educativo da criança.

Ao longo das entrevistas, notamos que famílias se colocaram como complementares à Escola Flamboyant na tarefa de educar/ensinar a criança, descrevendo-se como auxiliadoras/incentivadoras/promotoras de aprendizagens relacionadas ao contexto escolar, conforme consta nos relatos a seguir:

“... Então, a letra dela eu brigo com ela 'Íris tá ficando feio, uma grande e uma pequena Íris', 'Ah, mãe, mas eu não dou conta'. Mas se ela caprichar, ela consegue...”. (Genitora Irene).

“... Ela [Íris] levanta, toma seu cafezinho e tal... e se tiver alguma tarefinha... ela não é muito assim... 'Oh!! Hoje tem tarefinha e eu vou fazer!' Não... ela não. Ai 'Íris você tem alguma coisa pra fazer?', 'Ah, mãe a tia passou uns dever pra mim', 'Vamos fazer'. Aí começa 'Ah, mãe... que a minha mão tá doendo... ', 'Oh, primeiro, enquanto você não fazer as tarefinhas hoje você não vai poder brincar'. Aí ela faz... 'Ah, mãe dá doendo, posso parar um pouquinho?', 'Primeiro termina'...'. (Genitora Irene).

“... A alfabetização começa agora, né?, e eles já começam ensinando, e ela é louca pra aprender a ler, sabe? Chega aqui e pega alguma coisa, fala que vai ler e tal... E eu gosto muito de ler junto com ela (...) Ela gosta de ler. Não sabe ler não, mas fica lá falando coisa diferente do que tá lá, mas ela gosta...". (Genitora Irene)

“... Eu ensino eles a fazerem às vezes tarefinhas que eles trazem pra casa...”. (Genitora Flaviana)

“... Tem hora que eu estou ensinando os outros meninos ler, falo pra ele [Flávio], termino de ler o livro, 'Fala aquela palavra ali', ele não, 'Fala menino' e eles 'Ai, eu esqueci', e eu falo pra ele e aí ele olha aqui, só que ele não sabe, mas já fala aquela palavra...”. (Genitora Flaviana)

“... Eu pensava que já ia ensinar ele até escrever, mas o que eles ensinou esse ano foi escrever, que eu vi mais, foi ensinar a escrever as letras, né?, que ele já conhece todas as letras, os números, tudo ele aprendeu (...) Além do que eu ensinei pra ele aqui, porque eu ensinava muito pra ele, então ele foi e já sabia escrever o nome dele...". (Genitora Fabiola)

Notamos que as famílias indicaram o uso de diversas estratégias junto às crianças para auxiliá-las e incentivá-las na realização das tarefas escolares e na aprendizagem da leitura e da escrita. Tais falas atestam a importância que os pais atribuem à Educação de seus filhos e destacam a dedicação das mesmas, para que as crianças consigam se desenvolver na instituição escolar/na Educação Infantil. As famílias afirmaram complementar a Escola na educação/ensino de seus filhos. É importante salientar que pais do campo indicaram que há especificidades na ação das famílias e da Escola no que tange à criança, o que justificaria 
inclusive a relevância da ida da criança para a instituição escolar: “... Essa é a vantagem [de Íris ir para a Educação Infantil], que lá ela tá aprendendo as coisas certinhas lá, né? (...) Coisas aqui dentro de casa eu posso ensinar, mas tem coisas que é lá na Escola mesmo (...) Na Escola que ensina..." (Genitora Irene).

Segundo Fabíola, a frequência da criança na Educação Infantil possibilitaria que a mesma usufruísse espaços/recursos importantes para o desenvolvimento infantil e que estão ausentes no ambiente familiar:

“... A Escola leva as criança até pro computador, né?, com 5 anos, desde pequenininho já aprendendo... porque na roça, né?, você vê, a gente não tem computador, né? É mais difícil pra ter acesso (...) Você vê, tem parquinho pra eles. Menino gosta de brincar, né?, de 5 anos, nessa faixa de 5 anos. Tem a quadra coberta que a Escola, muitas não têm, a nossa tem, né?...". (Genitora da Fabrício)

No trecho apresentado, percebemos que a Fabíola indicou que a Escola Flamboyant seria relevante para as crianças, já que permitia que as mesmas tivessem contato com a informática. A inserção digital é destacada na fala de Fabíola como sendo significativa para a criança do campo, devido às características do território rural que possui acesso mais precário a computadores. É importante salientar que uma das famílias do campo, a de Iago, pontuou que em sua residência havia computador e internet.

Fabíola afirmou ainda que a ida da criança para a Educação Infantil na Escola Flamboyant possibilitaria que a criança usufruísse espaços voltados para a ludicidade, como o parque infantil e a quadra de esportes. Percebemos que a genitora de Fabrício indicou a importância do espaço do brincar na Escola Flamboyant. Ao analisarmos as falas das mães sobre o cotidiano de suas crianças no âmbito familiar, bem como a partir das visitas às famílias do campo, notamos que a possibilidade de disponibilização de espaços voltados para a ludicidade e nos quais as crianças possam movimentar-se, explorar os ambientes e a natureza se constitui como uma característica importante da Escola Flamboyant e que às vezes não está presente nas famílias do campo. Nas residências das famílias que vivem nas indústrias e nas fazendas, os espaços para as famílias viverem/para as crianças se desenvolverem são, por vezes, limitados pelas regras de uso estabelecidas pelas empresas ou pelos donos das fazendas, conforme indicam as falas a seguir:

“... O meu filho fez até um campinho ali... Um dia eu até falei pra ele que não era, porque não faz parte aqui das casas, porque aquilo ali é mais da empresa. Mas é aqui que elas brincam, só no pátio mesmo..." (Genitora Irene) 
“... Se o pai dele está em casa ele vai lá pro fundo andar de bicicleta com o pai, né? (...) Mas geralmente fica quieto em casa. Assistindo filme, DVD ou jogando no computador...". (Genitora Inês)

“... E o Flávio quando acorda de manhã já é televisão, deita na cama assistindo televisão. Eles gostam muito de brincar de bola aqui em cima dessa grama (...) Só isso e mais a televisão (...) Às vezes eles nadam, mas só que aí [represa da fazenda] tem peixe e eles não pode, quando não tem eles nadam, mas agora eles colocaram peixe aí ontem, aí não pode (...) Não pode nadar...”. (Genitora Flaviana)

“... Porque campo pra mim é fazenda, né?, roça pra criar gado, galinha, porco, plantar, agora aqui você não pode criar uma galinha (...) Não, não pode, não pode nada, no máximo que pode, o máximo que pode de bicho é os cachorro (...) Eu fiz uma hortinha ali pititinha, mas nem dá pra mexer nada porque é dificil, né? Então pra mim aqui eu considero morar na cidade..." (Genitora Inês).

Nas falas apresentadas percebemos que há, nas residências das famílias que moram nas fazendas e indústrias, a restrição dos ambientes e brincadeiras das crianças do campo, bem como das experiências que seriam possíveis em territórios rurais, como as de plantar/colher, a convivência com animais, dentre outras. Já no assentamento rural notamos, a partir da fala de Adriana, que o espaço para a criança brincar é amplo e permite que a criança esteja em contato com ambientes e recursos da natureza, “... [O Artur] gosta mais é de brincar de terra, ficar jogando pedra, esses trem assim, ir lá pro curral (...) É, tem a represa lá (...) Eles ficam brincando mais no quintal...”; “... Ele gostava, tinha muita vontade de ter um cachorrinho lá na cidade, mas meu marido nunca quis um cachorrinho (...) Aí depois que nós chegou aqui, aí tinha 5 cachorro aqui pititim, ai ele tá assim: 'Nossa mãe agora eu ganhei foi um punhado'...”.

Nesse contexto, notamos que a relevância da Educação Infantil para as crianças e famílias do campo pode se configurar de forma diferenciada, a depender das condições de moradia e de trabalho das famílias do campo.

Uma das entrevistadas ressaltou ainda a importância da Escola/Educação Infantil como forma de ascensão social: “... Pra mim o importante é ele [Artur] não ficar sem ir à Escola, mesmo que seja em qualquer lugar, estando indo na Escola, pra mim já é bom, a gente hoje sem estudo não é nada, né? (...) Assim, pra mim é uma vantagem muito grande, né? (...) Minha mãe sempre fala assim que a gente... o melhor que a gente deixa pro filho da gente é o estudo, né? Então assim, quando ele tiver na idade, ele ter um estudo assim, não passar pelo que a gente passou, né? Por isso que a gente incentiva em ir pra Escola aprender, se interessar, né? Pra ver se na frente consegue arrumar um serviço bom, né? Pra não ter que ficar sofrendo igual a gente sofreu, né?...” (Genitora Adriana). 
Dessa forma, notamos quanto a Escola/a Educação é valorizada por famílias rurais.

A partir dos dados discutidos anteriormente, percebemos que, para as famílias entrevistadas, a Escola teria como objetivo cuidar e educar a criança, complementando a ação da família. Mais especificamente, a Educação Infantil teria como objetivo permitir a interação entre as crianças e processos de desenvolvimento e de aprendizagens, ampliando os que ocorrem no âmbito familiar e comunitário. Diferentes significações foram construídas referentes ao papel da Pré-escola na alfabetização da criança, sendo que houve a defesa por algumas genitoras de que as crianças seriam alfabetizadas neste período, e por outras de que a alfabetização ocorreria no Ensino Fundamental.

Para as entrevistadas, as aprendizagens e desenvolvimentos ocorridos na Educação Infantil se constituiriam como uma preparação para o Ensino Fundamental. O sucesso da criança na Escola foi indicado como sendo importante pelas famílias, que veem a Educação como forma de ascensão social e garantia de um futuro melhor para suas crianças.

Como forma de sistematizar os dados construídos pelas famílias no que tange aos objetivos/relevâncias da Educação Infantil, construímos o quadro a seguir:

\begin{tabular}{c}
\hline Objetivos da Educação Infantil \\
\hline Possibilitar a socialização, a interação criança-criança \\
\hline Possibilitar aprendizagens e desenvolvimento da criança, ampliando os que ocorrem na família \\
\hline Preparar a criança para Ensino Fundamental \\
\hline Alfabetizar \\
\hline Não alfabetizar \\
\hline Educar a criança \\
\hline Complementar a família no cuidado e educação da criança
\end{tabular}

Quadro 20 - Objetivos da Educação Infantil - Relatos das famílias

\subsubsection{Aproximações e distanciamentos das significações das profissionais e das} famílias sobre objetivos da Educação Infantil no campo para as crianças/famílias do campo

A partir das discussões realizadas nos itens anteriores, notamos que significações das profissionais e das famílias sobre os objetivos da Educação Infantil ora se aproximaram e ora se distanciaram, conforme sistematizado no quadro a seguir: 


\begin{tabular}{|c|c|}
\hline \multicolumn{2}{|c|}{ Objetivos da Educação Infantil } \\
\hline Profissionais & Famílias \\
\hline $\begin{array}{l}\text { Complementar a família no cuidado e educação } \\
\text { da criança }\end{array}$ & $\begin{array}{l}\text { Complementar a família no cuidado e educação } \\
\text { da criança }\end{array}$ \\
\hline Não educar a criança & - ------------- \\
\hline $\begin{array}{l}\text { Substituir a família no cuidado e educação da } \\
\text { criança }\end{array}$ & ----------- \\
\hline $\begin{array}{l}\text { Possibilitar aprendizagens e desenvolvimento da } \\
\text { criança, ampliando os que ocorrem na família }\end{array}$ & $\begin{array}{l}\text { Possibilitar aprendizagens e desenvolvimento da } \\
\text { criança, ampliando os que ocorrem na família }\end{array}$ \\
\hline $\begin{array}{l}\text { Possibilitar a socialização, a interação criança- } \\
\text { criança }\end{array}$ & $\begin{array}{c}\text { Possibilitar a socialização, a interação criança- } \\
\text { criança }\end{array}$ \\
\hline Preparar a criança para Ensino Fundamental & Preparar a criança para Ensino Fundamental \\
\hline Alfabetizar & Alfabetizar \\
\hline Não alfabetizar & Não alfabetizar \\
\hline Educar a criança & Educar a criança \\
\hline $\begin{array}{c}\text { Melhorar condições de trabalho e de vida da } \\
\text { criança/família }\end{array}$ & $\begin{array}{c}\text { Melhorar condições de trabalho e de vida da } \\
\text { criança/família }\end{array}$ \\
\hline
\end{tabular}

Quadro 21 - Objetivos da Educação Infantil - Relatos das profissionais e famílias

Percebemos que as significações das famílias e das profissionais se aproximaram mas também se afastaram, quando estava em pauta a questão do papel da Educação Infantil na complementação das práticas educativas familiares junto à criança. As significações de profissionais aproximaram-se das significações das famílias do campo nos momentos em que houve a defesa de que a Educação Infantil complementa a família na tarefa de educar a criança. No entanto, outras significações das profissionais afastaram-se do que foi defendido pelas famílias, ao indicarem que não cabe à Escola educar a criança, mas somente à família. Ao defenderem tal concepção sobre o papel da Escola, tais profissionais aliaram-se a uma visão de Educação Infantil mais escolarizante. Houve profissionais que indicaram ainda que a Escola deve substituir o ambiente e práticas familiares, vistos como sendo inadequados para as crianças.

Conforme discutido no primeiro capítulo, os objetivos legais da Educação Infantil foram se modificando ao longo do tempo. Se antes Creches e Pré-escolas foram concebidas como instituições assistenciais e substitutivas das famílias (CRAIDY; KAERCHER, 2001; OLIVEIRA, 2002; SOUZA; KRAMER, 1988; PASCHOAL; MACHADO, 2009), hoje há a defesa, nas legislações e publicações nacionais, da Educação Infantil como instituição que cuida e educa a criança, complementando as práticas familiares (BRASIL, 1988, 1990, 1996). Porém, pesquisas sobre a relação entre Creches/Pré-escolas e famílias, citadas no primeiro capítulo do presente trabalho, vêm indicando a permanência no âmbito social de significações "novas" mas também "antigas" no que tange aos objetivos da Educação Infantil e, ainda, a defesa, em uma mesma Escola, de concepções semelhantes ou diferentes sobre o papel da 
Educação Infantil. Na investigação de Bhering e Nez (2002), por exemplo, tanto os profissionais como as famílias aliavam-se à concepção da Educação Infantil como sendo uma instituição assistencial. No estudo de Meira (2004), constatou-se que os profissionais ora defendiam a Educação Infantil como sendo assistencial e substitutiva das práticas maternas de cuidado e educação da criança e ora como sendo educacional; já as famílias indicavam a Educação Infantil ora como sendo assistencial e ora como sendo educacional. No estudo de Fortkamp (2008), verificou-se que famílias e profissionais defendiam a ideia da Educação Infantil como tendo o papel de cuidar e educar a criança, havendo, porém, outras demandas das famílias para além do que seria o papel da instituição, como acesso aos serviços de saúde. Os dados da nossa pesquisa indicaram que havia significações das profissionais que se aliavam às significações das famílias, consoantes com o que é defendido atualmente nas legislações nacionais (Cabe à Educação Infantil cuidar e educar a criança, complementando a ação da família), mas que havia também significações das profissionais diferenciadas das defendidas pelas famílias e nas legislações brasileiras (Não cabe à Educação Infantil educar a criança. Cabe à Educação Infantil substituir a família).

Apesar de haver tais distanciamentos, quando está em pauta o papel da Educação Infantil em relação à educação da criança e à família, notamos que outras significações das famílias e profissionais, referentes aos objetivos da Educação Infantil, aproximaram-se. As significações de famílias e profissionais aproximaram-se, ao defenderem a concepção de que a Educação Infantil teria como meta diversificar as interações entre as crianças e promover processos de aprendizagem e de desenvolvimento, preparando-as para o Ensino Fundamental. A alfabetização foi, em alguns momentos, indicada por profissionais e famílias como sendo objetivo da Educação Infantil, mas em outros momentos tal meta não foi atribuída às Creches e Pré-escolas. Ao discutirem tais objetivos da Educação Infantil, chamou-nos a atenção como as significações das famílias do campo, semelhantes às das profissionais de educação, estavam, em sua maioria, afinadas ao que é defendido legalmente como sendo o intuito da Educação Infantil. Outra questão observada na discussão sobre os objetivos da Educação Infantil foi que, em alguns momentos, famílias e profissionais se referiram às características do campo para pensarem sobre a temática. O ingresso da criança na Educação Infantil cumpriria o objetivo, para famílias e profissionais, de proporcionar à criança o acesso a ambientes e recursos que não estão presentes nas famílias residentes no campo, como a internet. Famílias do campo referenciaram ainda o isolamento das crianças do campo de seus pares (devido à distância geográfica entre as residências) para justificarem a importância da 
ida da criança para a Escola, tendo em vista que nesta instituição a mesma poderá interagir com outras crianças.

As significações de famílias e profissionais da Escola Flamboyant também se aproximaram ao indicarem que a Educação Infantil teria como objetivo contribuir com a trajetória escolar das crianças do campo, o que foi visto como meio de garantir melhores condições futuras de trabalho e de vida para as mesmas e a superação das condições precárias de vida às quais as famílias do campo são submetidas. Cabe mencionarmos que outras pesquisas também indicaram que famílias do campo valorizam a Educação dos filhos e veem a Escola como forma de ascensão social e melhoria das condições de vida (WATTE, 2009; FERRAZ, 2010).

Ao falarem da importância da Educação Infantil como forma de ascensão social, percebemos que as famílias construíram suas significações tendo em vista suas condições precárias de existência no campo. Já as profissionais construíram suas significações em diálogo com saberes existentes sobre a realidade das famílias atendidas, bem como em diálogo com discursos mais gerais sobre as famílias pobres e rurais. Conforme debatido anteriormente, o fracasso escolar e a pobreza são fenômenos que atravessam de uma forma geral os campos brasileiros (BRASIL, 2007; IBGE, 2009), sendo tal realidade citada por profissionais para justificar a importância da Educação Infantil também no campo investigado. A ideia de que a Educação Infantil no campo representa uma forma de buscar a igualdade entre campo e cidade também foi defendida pelas entrevistadas.

A partir das discussões realizadas acima, notamos que as significações das profissionais e das famílias sobre os objetivos da Educação Infantil ora se aproximaram e ora se distanciaram, conforme está sistematizado e representado nas figuras a seguir: 


\section{Significações aproximaram-se}

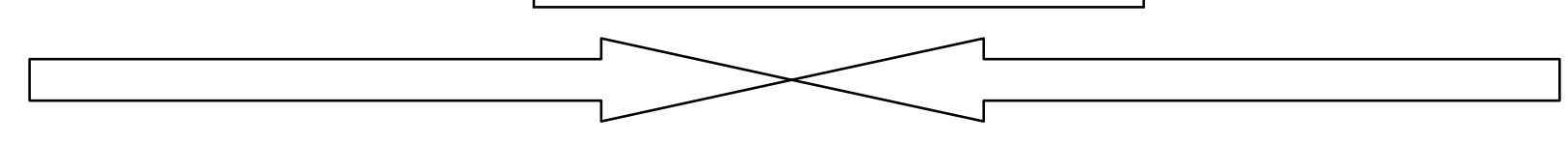

- A aproximação das significações das profissionais em relação às significações das famílias pareceu se relacionar com momentos em que dialogam:

- Com elementos da matriz sócio-histórica, mais especificamente, com concepções construídas historicamente sobre os objetivos da Educação Infantil, sendo algumas destas defendidas juridicamente (Educação Infantil tem como objetivo possibilitar interação entre crianças, aprendizagens, desenvolvimentos. A Educação Infantil deve educar a criança, complementando a família), e outras não defendidas juridicamente, mas ainda presentes no contexto social (A Educação Infantil deve alfabetizar a criança e prepará-la para o Ensino Fundamental).

- Com especificidades do campo, com as condições de Educação e de vida das populações rurais, indicando, por exemplo, a importância da Educação Infantil para as famílias do campo como forma de ascensão social.

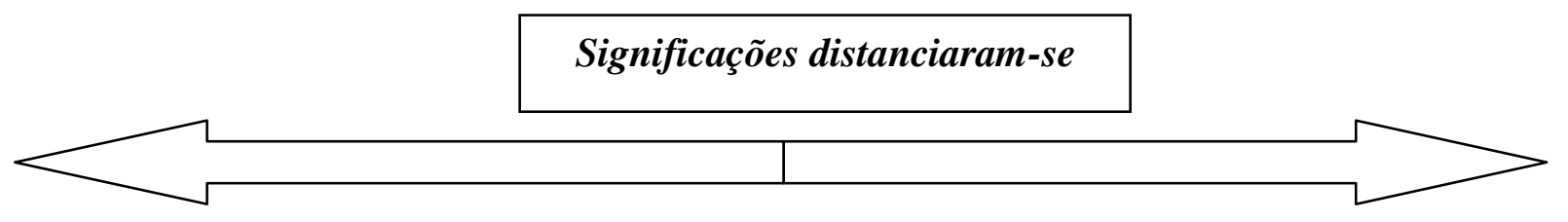

- O distanciamento das significações das profissionais em relação às significações das famílias pareceu se relacionar com momentos em que as profissionais dialogam com concepções presentes na matriz sócio-histórica (significações sobre Educação Infantil e sobre famílias pobres e do campo) e que expressam uma visão equivocada do papel da Educação Infantil, bem como das famílias populares e rurais (Educação Infantil não tem a função de educar a criança. Educação Infantil substitutiva do ambiente familiar, visto como impróprio para a criança). Tal movimento de afastamento parece vincular-se com a não apropriação pela Escola, de forma aprofundada, de objetivos da Educação Infantil (diferenciados do Ensino Fundamental), e com a precariedade de conhecimentos das famílias atendidas. Acreditamos que também contribuía para a defesa de objetivos diferenciados dos legalmente estabelecidos para a Educação Infantil o fato de a Escola estar voltada para o Ensino Fundamental. 
Notamos que tanto profissionais como famílias construíram suas significações em diálogo com elementos mais gerais da matriz sócio-histórica e com elementos do contexto investigado, o rural. Sobre os elementos mais gerais da matriz sócio-histórica, percebemos que os mesmos parecem ser apropriados pelas entrevistadas mantendo, inclusive, suas contradições. As entrevistadas mencionaram objetivos já consolidados e presentes nas legislações nacionais sobre a Educação Infantil e, concomitantemente, indicaram incertezas quanto ao que caberia a esta modalidade de educação e ao Ensino Fundamental no que tange, por exemplo, à questão da alfabetização, contradição esta também vivenciada no âmbito social brasileiro.

Tanto famílias como profissionais mencionaram ainda objetivos da Educação Infantil tendo em vista características das populações do campo. No entanto, percebemos que a concretude do meio rural é mais presente nas falas das famílias, ao construírem suas significações sobre os objetivos da Educação Infantil. Por exemplo, a importância de promover a interação criança-criança é citada como sendo um dos objetivos da Educação Infantil, tanto por famílias como para profissionais. Contudo, para as profissionais, a interação das crianças com seus pares é relevante para qualquer criança, seja ela do campo ou da cidade. Já para as famílias tal interação assume maior importância, é justificada devido às características do meio rural: distância entre as residências no campo e menor possibilidade de interação entre as crianças da comunidade. Cabe ressaltarmos que a relevância da Educação Infantil no contexto rural como meio de promover interações entre crianças e seus pares, tendo em vista o isolamento das famílias imposto pelas condições geográficas das suas comunidades, foi também observada por Teixeira e Alves (2008) em estudo realizado com crianças pré-escolares de uma comunidade ribeirinha da Ilha do Combu, em Belém do Pará.

Apesar de as características do campo estarem presentes em alguns momentos na discussão dos objetivos da Educação Infantil no campo, percebemos ainda que a realidade do campo não se constituiu algo norteador e fundante para se pensar o papel da Escola rural, ou seja, não há a argumentação por uma Escola cuja finalidade expresse e esteja articulada com a "alma" e o "corpo" do campo, conforme aspirado em publicações nacionais relativas à Educação Infantil no campo (SILVA; PASUCH, 2010). Ainda que profissionais tenham indicado a importância da Escola estar atrelada à realidade das famílias do campo e das famílias darem indicações em suas falas desta relevância, não percebemos uma defesa aprofundada de princípios da Educação do campo, mas sim uma maior aproximação dos princípios gerais e nacionais da Educação Infantil. Dessa forma, diríamos que há, no contexto 
estudado, movimentos de incorporação dos princípios da Educação do campo, mas não sua apropriação, conforme almejado nas legislações e publicações da área (BRASIL, 2002, 2008). 


\subsection{OS INSTRUMENTOS DA RELAÇÃO ENTRE A ESCOLA FLAMBOYANT E AS FAMÍLIAS DO CAMPO}

Ao serem questionadas sobre os encontros entre as famílias e a Escola, entrevistadas foram indicando em suas falas o que denominamos "instrumentos" utilizados nesta relação. $\mathrm{O}$ termo "instrumento" significa, de acordo com dicionários de Português: 1) O que é empregado para conseguir um resultado; 2) Meio para obter algo (MICHAELIS, 2012; DICIONÁRIO ON LINE, 2012). Neste item propomos indicar - a partir da análise das falas das profissionais de educação e das famílias do campo - os instrumentos utilizados para o estabelecimento e a construção da relação Escola e família. Intencionamos, ainda, discutir como a relação Escola e família ocorre na utilização de tais instrumentos.

\subsubsection{Significações das profissionais sobre os instrumentos da relação entre a}

\section{Escola e as famílias do campo}

A partir das falas das profissionais de educação, apreendemos que os instrumentos utilizados para o encontro, para a relação entre a Escola e as famílias eram: reuniões; eventos e festas; bilhetes; telefone; a própria criança; o motorista do transporte escolar; e a ida da família à Escola por solicitação de seus profissionais e em momentos não organizados pela instituição escolar. O contato com a Prefeitura para a melhoria do atendimento junto à criança e à família também foi evidenciado como sendo um instrumento da relação Escola e famílias.

No que se refere às reuniões promovidas na e pela Escola, profissionais relataram:

“... Ai a gente tem as reuniões, quatro reuniões pra entrega de notas e conversa com os professores e tem reuniões de conselho, né?, do conselho escolar, tem uma inicial em março, pra montar o conselho escolar, né?, da Escola, mas a representatividade é muito pouca, a dos pais, aí a gente marca pra fazer a reunião com os que estão aqui, às vezes não dá quórum, a gente tem que convocar uns pra vir, pra ver se dá, né?, pra fazer... Aí elege o conselho escolar e o conselho fiscal que é o conselho da caixa escolar, né? Elege os dois conselhos, aí sempre que tem verba a gente faz reunião do conselho, pra ver pra onde vai e com que que vai, né? (...) A gente faz reunião pra ver o destino do dinheiro, depois pra apresentar, falar (...) São mais as reuniões [os momentos de encontro com as famílias]...”. (Profissional Dirce)

“... Quando a gente tem reunião assim, reunião igual daquele tipo que você viu, né?, pra você vê, uma Escola inteira, né?, 400 e poucos alunos. Tinha o que...? Quantos pais tinha aquele dia? Se tivesse uns 30 aquele dia, ainda tinha muito. Devia ter uns 30, 40 pais, né? (...) É bem pouco, né? (...) A gente faz [reunião] bimestral, né? (...) Pra mostrar as notas pros pais e tudo, né? Porque antes o transporte o pai andava tranquilo, hoje não (...) Hoje o transporte é só para os alunos...”. (Profissional Vivian) 
Na fala de Dirce, observamos que a entrevistada indicou que o encontro da Escola com os pais ocorria por meio das reuniões do Conselho Escolar e das reuniões com as famílias, sendo estas realizadas bimestralmente, segundo as profissionais, devido à falta de transporte para os pais irem à Escola. Dirce e Vivian afirmaram que uma pequena parcela das famílias atendidas comparecia às reuniões. Entrevistadas pontuaram, conforme será mais bem discutido no próximo subcapítulo, que para garantir a presença da família na Escola, esta vinha buscando junto à Prefeitura a disponibilização de transporte escolar para os pais. $\mathrm{O}$ desinteresse das famílias em ir à Escola também é indicado por profissionais como um dos elementos que contribuía para a ausência das famílias nas reuniões escolares, "... [Os pais não vêm à Escola devido] à falta de interesse..." (Profissional Patrícia).

Diante da falta dos pais nas reuniões, Dirce indicou o uso pela Escola Flamboyant de recursos de autoridade junto às famílias: a convocação. A ida dos pais à Escola se daria por meio do uso do poder da instituição escolar em relação à instituição familiar. A realização da reunião do Conselho Escolar juntamente com a Reunião de Pais (para entrega de notas e conversa com os professores) apareceu também como uma estratégia da Escola para conseguir a representatividade suficiente de pais na reunião do Conselho Escolar. Sobre o fato de a realização da reunião com os pais ocorrer conjuntamente com a reunião do Conselho Escolar, Poliana afirmou: “... Eu não gosto não, de misturar não, porque acaba que conversa só coisas do Conselho, os repasses que às vezes as professoras querem fazer para os pais a maioria das vezes não faz...”. A profissional, nesta fala, realizou uma crítica à junção das reuniões do Conselho Escolar e dos pais, que reduziria o tempo para os professores se encontrarem e conversarem com as famílias.

De acordo com Dirce e Vivian, as reuniões do Conselho Escolar seriam realizadas para discutir a questão orçamentária da Escola, já as reuniões bimestrais com as famílias ocorreriam "pra entrega de notas e conversa com os professores". Vivian mencionou ainda que, em tais reuniões, havia a reafirmação de regras da Escola para as famílias e a escuta de pedidos ou queixas destas em relação à instituição escolar. Não evidenciamos, nas falas das entrevistadas, uma indicação das reuniões como troca de saberes sobre o cuidado e educação da criança. As reuniões, dessa forma, parecem mais voltadas para a discussão de questões relativas à gestão orçamentária, à organização da Escola, ao desempenho das crianças nas avaliações realizadas na instituição, bem como para a escuta de reclamações e solicitações das famílias atendidas.

Segundo Vivian, queixas relativas à Escola e que se referiam ao transporte escolar das crianças eram realizadas pelos pais nas reuniões: 
“... Com pai assim, hoje eu vejo assim, porque quando a gente faz reunião, geralmente pergunta pro pai: 'Você quer alguma coisa, reclamar alguma coisa...?'. Então assim, a reclamação geral é transporte [das crianças] (...) O pai assim, 'Ah o diretor é bom, o professor é maravilhoso, tudo é bom, só...', entendeu? (...) Vamos supor, né?, se o pai vai, ele mora aqui nessa ponta. Aí o motorista vai, mas o motorista chega até aqui, mas aqui não dá pra ir, porque igual você acompanhou você viu. Tem lugar que é estreito, não tem como o ônibus virar, não tem como a van virar. Não, mas o pai quer que pega na porta, entendeu? 'Ah porque que o fulano pega?'. Entendeu? Então eu acho assim, infelizmente a gente vive nunca sociedade que o que, quanto mais a pessoa recebe, mais ela quer receber e nunca está satisfeita...". (Profissional Vivian)

De acordo com Vivian, as famílias do campo manifestavam, nas reuniões, estarem satisfeitas com diversos aspectos da Escola, indicando, porém, que as mesmas questionavam o trajeto percorrido pelo transporte escolar/a distância em que buscavam as crianças em suas residências. Na fala de Vivian, notamos que esta mencionou que tal queixa por parte das famílias seria equivocada e defendeu que a família adotava a postura de "estar sempre pedindo" e de "estar sempre insatisfeita", o que expressaria, segunda a entrevistada, uma tendência social. Nesse contexto, o que talvez seja para os pais uma solicitação pela melhoria da qualidade do atendimento oferecido às crianças e às famílias do campo era vista, pela profissional de educação, como sendo algo excessivo na relação Escola e família. No entanto, apesar da existência de diferentes pontos de vista de pais e profissionais sobre temáticas trazidas pelas famílias nas reuniões, Vivian evidenciou que havia, nestes espaços, falas das famílias sobre o atendimento na Escola e a escuta das mesmas pelos profissionais da instituição escolar.

Vivian indicou, ainda, em outros relatos, que as reuniões com as famílias na instituição escolar, por vezes, se constituíam como um espaço de tensões entre a Escola e pais atendidos, conforme indica o trecho a seguir:

“... A Escola, fica uma coisa desgastada que eu lembro que no dia da reunião chegou um pai em mim e falou assim: 'Ah, vocês não vão ficar no blá, blá, blá não, vocês vão entregar as notas?'. Entendeu? (...) A Escola, a gente tem muito hábito assim de ler o que pode, o que não pode. Então geralmente o pai que vai na reunião é aquele pai que acompanha mais os filhos. Eu te falo experiência minha enquanto mãe. Quando eu chego na reunião que a diretora começa a ler aquele tanto de coisa lá pra gente, ai você pensa assim: 'Ai que vontade de sair correndo'. Sabe?, porque assim, a gente vai pra saber como o filho da gente tá específico, né? Acho assim, precisa supor então assim, os nossos pais também eu vi a cobrança deles, eu falei: 'Ah, então não é só a gente que reclama, né?' (...) Os pais também sentem esse lado...". (Profissional Vivian)

Vivian afirmou que já ouvira críticas dos pais no que tange ao formato da reunião promovida pela e na instituição escolar. Para a entrevistada, as famílias iam às reuniões para buscar informações sobre a criança e não sobre a Escola, suas regras. A fala do pai poderia 
indicar um incômodo frente à atividade de reafirmação das regras da instituição escolar. Ao falar sobre tal acontecimento, a entrevistada pareceu aproximar-se da visão dos pais sobre a reunião, colocando-se no lugar dos mesmos, o que indica uma postura da profissional de escuta e de busca pelo entendimento das reivindicações das famílias. Vivian manifestou ainda compreender a posição de pais que, segundo a profissional, deixariam de ir à Escola quando vislumbram que irão ouvir queixas da instituição sobre o filho: "... é muito difícil o pai vir, do [aluno] custoso. O pai pensa assim, 'Porque que eu vou na Escola, pra ver reclamar do meu filho?'..." (Profissional Vivian).

Diante da ausência das famílias nas reuniões, uma das entrevistadas pontuou que seria necessário que a Escola planejasse e realizasse encontros com as famílias em outros formatos, sendo estes mais prazerosos para os pais, o que aponta para um movimento da profissional de reflexão, sobre novas possibilidades de relação com as famílias e de garantir a presença das mesmas no âmbito institucional: “... Então às vezes eu penso assim, que como fazer, o que fazer pra trazer esses pais pra Escola? Não convocando pra uma reunião, mas sim pra um lanche, pra um café da tarde, tipo uma confraternização. Pra uma conversa mais agradável, não a palavra reunião porque se você fala a palavra reunião eles não vêm..." (Profissional Patrícia).

Além das reuniões, profissionais afirmaram que outros meios de encontro entre Escola e famílias seriam os eventos e festas promovidos pela e na instituição escolar, tal como indicam os relatos a seguir:

“... Festividades também, né? (...) Nós fizemos festividades, nós convidamos a comunidade, eles vem, aqueles que têm transporte vêm...". (Profissional Vilma)

“... Festa, a gente sempre faz a Festa Junina, né? (...) E tem a Feira de Ciências, onde faz a amostra dos meninos (...) A participação da comunidade... é convidada mas eles vêm em transporte próprio (...) É pouca também. É, os que têm [transporte próprio] (...) é uma minoria que tem (...) E quando tem também talvez não tem dinheiro pra pôr a gasolina. Às vezes compra o carro mas não tem como andar no carro...". (Profissional Dirce)

A presença dos pais nos eventos e festas promovidos pela Escola era percebida, pelas profissionais, como restrita. As famílias que compareciam nesses momentos, de acordo com as entrevistadas, seriam aquelas que possuíam carro próprio e condições financeiras de abastecê-lo. Tais falas indicam como condições materiais de vida de pais do campo (ausência de carro próprio e dinheiro) e características do campo (distância geográfica entre Escola e 
família) constituem-se como elementos que atravessam e configuram a relação entre as instituições escolar e familiar e contribuem para distanciamentos entre as mesmas.

Tendo em vista o distanciamento com as famílias, a profissional mencionou que a Escola Flamboyant também utilizava outros instrumentos para comunicar com os pais das crianças atendidas:

“... O contato com os pais ficou muito restrito (...) Tanto é que assim, na questão da rematrícula, a gente manda a rematrícula pelo aluno, né? E ele traz de volta...”. (Profissional Vilma)

“... Eu tenho contato com a família é um... um... um maior contato através de bilhetes... Telefone, né?, que a maioria deles agora tem telefone rural, quando pega, né? (...) Às vezes a gente liga, mas é raro o celular atender, porque tem uns lugares que o celular não pega...”. (Profissional Vilma)

Vilma apontou a criança como uma mediadora na relação Escola e família. A realização de outras estratégias pela instituição escolar para comunicar com as famílias do campo também é mencionada, como a utilização de bilhetes e de telefone. Sobre o uso do telefone, Vilma afirmou que a maioria das famílias possuía telefone rural. No entanto, o uso do mesmo, segundo a entrevistada, era dificultado pelo fato de estarem no campo, o que fazia com que o telefone não funcionasse adequadamente. A entrevistada indicou, dessa forma, como características do meio rural do município - qualidade da telefonia - também é um elemento que atravessa e configura a relação Escola e família.

No que se refere ao uso do bilhete pela Escola, outra profissional pontuou:

“... Geralmente quando é algum problema que envolve tipo uma agressão, alguma coisa assim que o aluno machuca, tudo, é feito um bilhete pros pais, aonde no caso é explicado o que, que aconteceu tudo, explicando direitinho. Se for o caso de uma coisa mais séria a gente chama a presença dos pais aqui pra gente procurar resolver, mas quando a gente não pode resolver. Mas quando tem algum tipo assim, de agressão ou de qualquer outro problema que seja um pouquinho mais sério isso é passado pra direção e a gente faz no caso, um bilhete pros pais e quando fica como se diz um pouquinho mais sério o problema a gente chama até os pais pra conversar e procurar resolver...". (Profissional Paula)

“... Porque a criança é, não é porque ela tem cinco anos que ela não dá trabalho não porque dá trabalho (...) Dá trabalho, briga, bate, inclusive que você já presenciou muito, você sabe até alunos que nós temos lá da sala que dá trabalho, é um dos que eu mandei vários bilhetes pra mãe, então o que que acontece? É... é você chama a mãe pra saber o porquê... Os de cinco anos é assim normalmente some... às vezes um coleguinha bate, dá pedrada, morde, ou qualquer coisa, então você manda o bilhete pra comunicar o pai o que que aconteceu (...) Às vezes, você manda o bilhete pra chamar o pai porque um outro coleguinha bateu, mordeu, sabe? Quando o caso fica mais grave um pouquinho (...) Então os bilhetes é variados... Ou às vezes porque a criança cai, igual a Escola é muito grande eles correm muito (...) Vai pro parque, cai do balanço, cai de não sei aonde, machucam, então esses são os casos (...) Manda o bilhete por isso...". (Profissional Patrícia) 
De acordo com Paula e Patrícia, o uso de bilhetes pela Escola se daria em situações pontuais e problemáticas como a ocorrência de acidentes com as crianças e de conflitos entre as crianças que resulta em ferimentos. Em casos mais graves, os bilhetes seriam utilizados para solicitar aos pais o comparecimento à instituição.

Sobre a solicitação da presença dos pais na Escola, profissionais afirmaram:

“... E a gente assim, quando a gente precisa de... é... às vezes tem... a gente precisa de... um... é trabalho... ver... assunto específico, a gente convoca aquele pai até a Escola... A gente convoca, fica aguardando, ou... é... é... A gente convida ele, né? Pra vir (...) Ou às vezes quando o caso tá muito agravante, a gente... Aí você condiciona... Aí você condiciona a... a ... a criança vir na Escola com a presença dos pais...". (Profissional Vilma)

“... [Os pais vêm à Escola também] quando são convidados, porque é... Às vezes a criança não está apresentando uma... uma... uma disciplina desejável, né?, e a gente convida o pai (...) Pra estar na Escola pra gente relatar... pra fazer o relatório do... do, da situação... daquela criança...". (Profissional Vilma)

“... Tem alunos que chegam aqui na Escola muito assustados, sabe? Começa a dar trabalho, mas não sei o que, mas você vai ver lá atrás na história dele tem muita coisa, então às vezes por a criança (...) por passar por alguma coisa, chega aqui ela não confia em você, ela não confia nos colegas então ela começa a dar trabalho, começa a querer bater, começa a querer morder, sabe? Aí é onde você tem que chamar os pais, pra saber se tá acontecendo alguma coisa com ele fora daqui, porque que aqui ele tá agressivo, ou porque que às vezes ele está batendo muito, porque que ele não presta atenção... Tem toda uma história aí atrás assim...”. (Profissional Patrícia)

Nos relatos acima, Vilma indicou que, diante da necessidade de a Escola conversar com a família, a instituição "convoca" os pais. O uso do verbo "convocar" evidencia a utilização de recurso de autoridade da Escola em relação à família. No mesmo relato a profissional afirmou que "convida" a família a ir à Escola, o que poderia indicar uma (re)avaliação dela mesma sobre a fala da relação da instituição e suas práticas junto aos pais. No entanto, a entrevistada mencionou ainda que outra forma de a Escola garantir a presença da família na instituição seria: “... Aí você condiciona $a$... a... a criança vir na Escola com a presença dos pais...", o que novamente nos aponta para o uso do poder da Escola sobre a família. Cabe pontuarmos que, em outros relatos, Patrícia apontou que a Escola às vezes utilizava outras estratégias para garantir a presença dos pais na instituição, como a intervenção de Assistentes Sociais da Prefeitura e das Indústrias onde as famílias residiam e trabalhavam. Tais estratégias serão mais bem discutidas no item 5.5. Situações problemáticas na relação entre a Escola Flamboyant e as famílias do campo.

Vilma pontuou que a convocação da família para comparecer à instituição escolar ocorreria para que esta pudesse “... relatar (...) [a] situação... daquela criança...” para os pais, 
evidenciando a condição de ouvinte das famílias sobre os problemas apresentados pela criança no âmbito escolar.

Nas falas apresentadas, notamos ainda que a convocação dos pais para comparecerem à Escola ocorria em casos que a criança apresentava, na visão das entrevistadas, comportamentos não almejados pela instituição. A manifestação de tais comportamentos, para Patrícia, se daria em função de problemas vivenciados pela criança em ambientes diferenciados do escolar. Para garantir a presença dos pais na Escola, em tais casos, Patrícia relatou que solicitava ao motorista do transporte escolar que comunicasse aos pais sobre a convocação:

“... Então já teve vez aqui de eu ter que ir lá no motorista da van, entregar o bilhete na mão dele e falar assim 'Pelo amor de Deus entrega na mão do pai', do pai, porque justamente pelos pais não virem à Escola, às vezes muitos não têm telefone, não têm contato com eles. Quando você manda um bilhetinho, o menino pega o bilhete joga fora no meio do caminho. Não tem como a gente falar com o pai dele mesmo. Principalmente de granja, porque o quê que acontece? Na granja a gente não entra (...) Só até a portaria. Só até na portaria....”. (Profissional Patrícia)

Patrícia mencionou que o uso de instrumentos na relação com as famílias às vezes era dificultado pelo fato de estas residirem dentro de indústrias que não permitiam a entrada de profissionais da instituição escolar e de outras pessoas em seu interior, o que, a nosso ver, mantêm tais famílias em certo isolamento social.

Além da solicitação às famílias para comparecer à Escola, promoção de reuniões, eventos e festas, uso de bilhetes, de telefone, da criança e do motorista do transporte escolar para se relacionarem com os pais, profissionais afirmaram ainda que a instituição colocava-se “aberta" para receber as famílias em momentos que as mesmas podiam/desejavam ir à Escola:

“... São mais as reuniões [os momentos de encontro com as famílias]. E agora a Escola tá sempre aberta para atendê-los (...) Qualquer dia que ele vir ele vai ser atendido pelo professor, arruma pessoa pra ficar na sala que a gente sabe que a disponibilidade deles é pouca, né? A dificuldade pra vir também é pouca, o poder aquisitivo pra vir também é pouco, então quando mais liberdade e mais chance de vir, que possa contribuir com eles...". (Profissional Dirce)

Dirce defendeu a ideia da "Escola Aberta" como forma de possibilitar a ida das famílias à instituição escolar. A entrevistada mencionou que as famílias do campo teriam pequena disponibilidade e condições financeiras para irem à instituição escolar. Partindo da concepção de que as famílias teriam obstáculos para irem à instituição escolar, Dirce indicou que a Escola buscava contribuir com os pais, tendo em vista suas características e condições de vida, flexibilizando sua rotina para recebê-los. 
Sobre tais momentos que as famílias buscavam ir à Escola por iniciativa das mesmas, outra profissional afirmou, baseando-se na sua experiência como docente na instituição:

“... Não, basicamente eu não tenho nenhum [momento de encontro com as famílias], porque o período que eu estou aqui dando aula eu estou exclusivamente... pra ministrar minhas aulas... Eu não tenho nem módulo, não tenho nem como atender. É claro que se algum dia ou outro, um pai ou a mãe quiser falar comigo pra... pra querer algum esclarecimento com relação a minha disciplina, qualquer coisa, querer conversar, e a direção da Escola no caso, arruma alguém pra ficar no meu lugar enquanto eu tenho..., desde que seja também um assunto que seja..., que a direção veja como um assunto importante que vai me tirar lá, como se diz, do grupo de alunos que eu estou ministrando, pra tentar no caso, sentar e resolver o problema com os pais...". (Profissional Paula)

Paula mencionou que sua atuação na Escola estaria voltada para o atendimento da criança e que não haveria condições de atender às famílias, tendo em vista sua carga horária na instituição, suas condições de trabalho. O foco no ensino/nas aulas parecia caracterizar a atuação da profissional, aproximando-a de uma visão mais escolarizante da Educação Infantil. O distanciamento das famílias foi indicado por Paula que trouxe elementos, em sua fala, que apontam para a existência de uma série de condições para que haja o encontro com a família (em situações que os pais vão à Escola em momentos não organizados pela instituição) e que seriam: 1) que tais encontros sejam pontuais, 2) que a direção da Escola envie um professor substituto para ficar com as crianças possibilitando o encontro de Paula com a família, 3) que a direção da Escola avalie que a solicitação da família para conversar com a professora é pertinente e justifique o afastamento da docente da turma de Educação Infantil. Ao afirmar que tais encontros - entre professora e pais - se dariam em casos em que a direção da instituição escolar considerava a temática trazida pela família como sendo relevante, a profissional indicou a existência, nesse momento, de uma relação de maior poder da Escola em relação à família, já que caberia à direção da instituição escolar decidir se a família teria ou não a possibilidade de conversar com aquela (docente) que trabalhava junto à sua criança. A ideia de que tal encontro ocorreria para solucionar situações problemáticas também apareceu na fala de Paula.

Em um relato de Vivian, evidenciamos a menção, pela entrevistada, de que pais iam à Escola por iniciativa dos mesmos em casos de acidente na instituição escolar envolvendo a criança, conforme será mais bem discutido no item 5.5. Situações problemáticas na relação entre a Escola Flamboyant e as famílias do campo. Ao analisarmos as falas das profissionais, percebemos ainda que famílias do campo, por iniciativa das mesmas, relacionavam-se com a Escola em outras circunstâncias, por meio da realização de intervenções junto à Prefeitura municipal, conforme consta na fala a seguir: 
“... Assim, em época de chuva, quando as estradas estão muito ruins (...) tem umas vans que vão em uns lugares muito ruins aí, ou o ônibus que não descem lá no assentamento. Os últimos lotes do assentamento são bem dentro de uns buracos assim e o ônibus não desce (...) Esse ano não deu problema de chuva que o ônibus não descesse... Toda vez ele conseguiu descer, e eles vão arrumando, né? A Prefeitura procura cascalhar, onde... Os pais chamam, onde vão descer pra cascalhar, né? Esse ano não tive problemas...". (Profissional Dirce)

No trecho acima, notamos que Dirce relatou que havia a demanda dos pais à Prefeitura pela melhoria das estradas utilizadas pelo transporte escolar. Este caso apontou-nos uma busca, pelas famílias do campo, pelo oferecimento de uma Escola com maior qualidade no campo e, concomitantemente, evidenciou um envolvimento e uma aproximação dos pais com a instituição escolar.

Nas discussões realizadas anteriormente, percebemos que profissionais da educação mencionaram que diferentes instrumentos eram utilizados na relação Escola e família e que expressavam uma mobilização da instituição para receber e conversar com os pais atendidos e, ainda, uma busca pela família de melhoria do atendimento oferecido. O uso de tais instrumentos cumpriria diversos objetivos, tais como: possibilitar conversas entre famílias e profissionais sobre o atendimento; informar a família sobre desempenho e problemas de comportamento do filho na Escola; informar aos pais sobre acidente envolvendo a criança; informar aos pais sobre regras e orçamento escolares; realizar a rematrícula da criança e solicitar à Prefeitura melhorias do atendimento na Escola. É importante salientar que não houve a menção, pelas profissionais, de que tais instrumentos seriam utilizados para a discussão do projeto, das propostas políticas e pedagógicas da instituição. Ressaltamos, ainda, que tais instrumentos, na sua maioria, foram citados como sendo meios de a Escola contemplar suas metas e finalidades junto às famílias.

Ao falarem sobre os instrumentos da relação Escola e família, profissionais ressaltaram que a reunião com os pais seria um dos principais meios para se encontrarem com as famílias do campo. No entanto, entrevistadas afirmaram que a participação das famílias em tais momentos era escassa. A pouca participação das famílias nas reuniões foi relacionada, nas falas das profissionais, à distância geográfica entre a Escola e as residências das famílias associada à falta de transporte dos pais, bem como ao desinteresse das famílias em se envolverem com as atividades da Escola. Profissionais afirmaram, ainda, que o formato das reuniões restringia o tempo para os professores conversarem com as famílias e, ainda, tornava 
desestimulante a participação dos pais nesses momentos promovidos pela instituição escolar, contribuindo para desgastar a relação família e Escola.

Como forma de sistematizar os dados discutidos neste item, apresentamos o quadro a seguir:

\begin{tabular}{|c|c|c|}
\hline $\begin{array}{l}\text { Instrumentos da } \\
\text { relação Escola e } \\
\text { família }\end{array}$ & $\begin{array}{c}\text { Finalidades da } \\
\text { utilização dos } \\
\text { instrumentos }\end{array}$ & $\begin{array}{c}\text { Como ocorria a relação Escola e famílias com o uso } \\
\text { dos instrumentos }\end{array}$ \\
\hline Reuniões & \multirow{9}{*}{$\begin{array}{l}\text { - Escola: } \\
\text { - Entregar notas. } \\
\text { - Informar regras da } \\
\text { instituição. } \\
\text { - Discutir com pais } \\
\text { orçamento escolar. } \\
\text { - Informar acidente ou } \\
\text { problema de } \\
\text { comportamento da } \\
\text { criança. } \\
\text { - Realizar rematrícula. } \\
\text { - Família: } \\
\text { - Opinar sobre } \\
\text { atendimento. } \\
\text { - Prefeitura: } \\
\text { - Melhorar a qualidade do } \\
\text { atendimento da Escola. }\end{array}$} & \multirow{9}{*}{$\begin{array}{l}\text { Relação entre pais e profissionais não era estabelecida } \\
\text { devido à não mobilização e presença dos pais na Escola. } \\
>\text { Relação era estabelecida com alguns pais que se } \\
\text { mobilizavam para irem à Escola. } \\
>\text { Relação era estabelecida devido à mobilização da } \\
\text { Escola para receber os pais e para se comunicar com os } \\
\text { mesmos, por meio da abertura da Escola e uso de diversos } \\
\text { instrumentos. } \\
>\text { Relação era restrita, mas estabelecida com algumas } \\
\text { famílias por meio do uso de diversos instrumentos. } \\
>\text { Relação era distanciada devido a desinteresse da } \\
\text { família. } \\
>\text { Relação era distanciada devido à distância geográfica } \\
\text { entre Escola e famílias e falta de transporte para/dos pais. } \\
>\text { Relação era desgastada devido ao formato das } \\
\text { reuniões. } \\
>\text { Relação era restrita devido ao pouco tempo disponível } \\
\text { para professores conversarem com pais nas reuniões. }\end{array}$} \\
\hline Festas e eventos & & \\
\hline Bilh & & \\
\hline Telef & & \\
\hline Cria & & \\
\hline Motorista esc & & \\
\hline $\begin{array}{l}\text { Ida da família à } \\
\text { Escola por } \\
\text { solicitação da } \\
\text { instituição }\end{array}$ & & \\
\hline $\begin{array}{l}\text { Ida da família à } \\
\text { Escola por } \\
\text { iniciativa dos pais }\end{array}$ & & \\
\hline $\begin{array}{l}\text { Contato com } \\
\text { Prefeitura } \\
\text { Municipal }\end{array}$ & & \\
\hline
\end{tabular}

Quadro 22 - Instrumentos da relação Escola e família - Relatos das profissionais

Dessa forma, percebemos que características do campo (distância geográfica); características do município (não disponibilização de transporte escolar para os pais); características da Escola (formato das atividades realizadas junto às famílias); características das famílias rurais (precárias condições econômicas das famílias rurais e desinteresse pela Escola) foram indicadas, por profissionais da educação, como elementos que atravessavam a relação Escola e família e contribuíam para a pouca participação dos pais, percebida pelas entrevistadas, no âmbito escolar. Diante da participação dos familiares aquém da desejada pela Escola, profissionais relataram que a instituição recorria a recursos de autoridade para conseguir a presença dos pais no âmbito escolar, tais como convocar a família e condicionar a ida da criança à Escola à presença dos pais, tornando maior o poder da Escola na relação com as famílias. Profissionais mencionaram ainda a solicitação pela Escola, junto ao Poder Público, da disponibilização do transporte escolar para possibilitar a ida e maior participação das famílias nos eventos da instituição. Não evidenciamos, a partir dos relatos das profissionais, uma mobilização da comunidade escolar visando modificar os formatos dos 
encontros entre Escola e famílias com o intuito de torná-los mais dialógicos e atrativos, contribuindo para uma maior e melhor participação dos envolvidos nesses espaços.

\subsubsection{Significações das famílias sobre os instrumentos da relação entre a Escola e as famílias do campo}

A partir das falas das famílias, apreendemos que os instrumentos utilizados para o encontro e relação entre a Escola e as famílias do campo eram: reuniões; eventos e festas; bilhetes; telefone; irmã da criança; motorista do transporte escolar; e ida da família à Escola por solicitação de seus profissionais e em momentos não organizados pela instituição escolar. O contato com a Prefeitura para a melhoria do atendimento junto à criança e à família também foi indicado como sendo um instrumento da relação Escola e família.

Sobre as reuniões promovidas na e pela Escola, famílias relataram:

“... [Encontramos com a Escola] Só nas reuniões. Inclusive esses dias, sexta-feira, teve reunião e eu não pude ir (...) Foi... de três a duas [reuniões] com essa...”. (Genitora Irene)

“... Ah, esse ano nunca chamou pra reunião de pais. Uma vez chamou mesmo, mas aí não fui...”. (Genitora Inês)

“... Reunião com os pais, eles fez só duas esse ano. Mas a professora, a diretora já avisou que é por falta de mesmo, de transporte pros pais, que é muito difícil de ir, mas sempre eles chamam pra alguma coisinha ou outra eles chamam...". (Genitora Fabíola)

Notamos que Irene afirmou que as famílias encontravam com a Escola “... só nas reuniões...", indicando tais momentos como sendo os únicos. No entanto, Irene, ao longo da entrevista, e outras famílias participantes do estudo ressaltaram que havia a utilização de outros instrumentos de encontro com profissionais da instituição escolar.

No que tange às reuniões realizadas pela Escola Flamboyant, notamos que Irene e Inês indicaram incertezas quanto ao número das mesmas. Já Fabíola afirmou que a Escola promoveu duas reuniões com as famílias, no ano de realização da pesquisa. Ao falarem da última reunião realizada na Escola, Fabíola e Flaviana indicaram a ida à mesma por meio, respectivamente, de "carona" e de mototáxi. No entanto, outras entrevistadas afirmaram que não compareceram à reunião tendo em vista a ausência de transporte, “... E dia de sexta meu esposo vai de carro pra faculdade, então aí eu também... não teve como... porque era cinco e 
meia, aí pra mim ir eu teria que ir de carro e ele tinha que ir pra Escola e não teve como eu ir. Mas quando tem a oportunidade eu vou...” (Família de Íris); “... Não fui... Ir que jeito? Pra ir até que dava pra ir, eu ia no ônibus, mas ia voltar de que jeito? (...) Esperar achar uma carona de lá pra cá?, muito difícil...” (Genitora Inês).

Ao serem questionadas sobre a opinião a respeito da última reunião realizada pela instituição escolar, as famílias afirmaram:

“... Até boa. A Dirce é muito boa, fala muito bem, explica muito as coisas, apresenta as coisas da Escola, achei boa...”. (Genitora Fabíola)

“... Eu achei legal, bonita a reunião delas (...) [Não conheci a professora] do Flávio não. Só a professora do Florival e do Florindo (...) Nem o nome dela eu sei direito... Eu perguntei pra ele aqui 'Como é que chama sua professora?'. Aí um dia ele fala, diz que é tia Pamela, e a outra? Não sei, e eu nem sei o nome dela ...". (Genitora Flaviana)

No relato acima, percebemos que Fabíola avaliou positivamente a reunião promovida na instituição escolar, indicando que a mesma se constituiu como um momento da Escola falar para as famílias, de fornecer informação aos pais sobre o atendimento na instituição escolar. Flaviana, que possuía mais dois filhos na Escola, resumiu que tal reunião, seria um dia “... de pegar os boletins...” das crianças: as do Ensino Fundamental.

Além das reuniões, famílias indicaram que outros instrumentos de encontro entre famílias e instituição escolar seriam as festas e eventos promovidos pela e na Escola:

“... Chamada pra ir, chamada, direto eles chamam quando tem festinha, eles fazem muita festinha, já fez festinha pras mães. No Dia dos Pais, eles fez festinha, chamou os pais, no caso do Fabrício não foi ninguém porque ele tinha acabado de perder o pai dele, eu não mandei ninguém, nem representante. Meu primo até queria ir, brincar de futebol lá, eu não deixei ir, porque tinha acabado de perder o pai. Eles chamam sempre que faz alguma comemoraçãozinha, faz dia da família, e sempre eles me chamam pra alguma coisa...". (Genitora Fabiola)

“... Aqui eu nunca fui chamada [para festa] ainda não, porque... eu acho que aqui teve já, mas eu não fui não, por causa da... aqui não tinha condução pra gente ir. Teve uma festinha aqui no São João $e$ eu não pude ir por causa que não teve, não tinha carro pra nós irmos (...) Porque o carro aqui que entra aqui é só van que vem pegar eles. Ela não leva, não dá carona pra ninguém... E se nós quiser ir, não tem como nós ir, só se for a pé... A pé, ichi!, é longe...”. (Genitora Flaviana)

“... É, teve uma vez que teve uma Festa das Crianças que, né?, eu fui. Esses dias, não sei se foi mês passado, ou no começo do mês agora, teve um negócio lá só que não deu pra mim ir porque ele [Adriano] estava viajando e quando ele está aqui, dá pra mim ir, porque daí a gente vai...". (Genitora Adriana) 
Percebemos que as famílias mencionaram que a instituição escolar promovia eventos e festas, tais como do Dia das Crianças, das Mães, dos Pais, da Família e Festa Junina, e indicaram a realização de diversos convites da Escola para a ida das famílias nestas circunstâncias. Notamos que novamente as famílias afirmaram a impossibilidade de participar de atividades na Escola, tendo em vista a distância geográfica entre a instituição escolar e suas residências associada à falta de transporte.

Além das festas e reuniões, a análise das entrevistas das famílias indicou que pais compareciam à Escola em outros momentos por solicitação da instituição escolar. Estes encontros, de acordo com as falas das famílias, eram requisitados pela instituição escolar para conversar sobre problemas, identificados pelos profissionais de educação, relacionados a comportamentos da criança no âmbito escolar, conforme será mais bem discutido no item 5.5. Situações problemáticas na relação entre a Escola Flamboyant e as famílias do campo.

Em relato da mãe de Íris, constatamos ainda que as famílias iam à Escola por solicitação da instituição escolar e mediante pedido da criança, em casos envolvendo a saúde da criança: “... A Íris esses dias arrancou um dente e tive que ir levar ela no dentista pra arrancar o dente. Aí ela... eu creio que onde deu a anestesia doeu. Aí ela chorou e pediu pra ligar e eles ligaram pra mim ir buscar. Aí eu fui lá buscar ela..." (Genitora Irene).

Segundo as famílias entrevistadas, pais também compareciam à Escola por iniciativa/desejo/necessidade dos mesmos, conforme consta nas falas a seguir:

“... Nos dois primeiros dias eu fui junto (...) Eu perguntei pra Vilma se eu, eu não usei o transporte sem perguntar pra Vilma, porque o transporte não é liberado pros pais, igual você deve saber lá. Eu perguntei pra ela, ela falou, 'Conversa com o motorista, se o motorista te trouxer, você pode vir'. Eu conversei com o motorista, por isso que ele me levou (...) Foi eu que quis... [A Escola] Não, não pede, não pede [para ir], mas também não opõe. Igual o dia que eu fiz a matrícula eu perguntei se eu podia ir, ela falou que podia, se a gente quiser ir, visitar a Escola, a Escola está aberta... Igual o dia da reunião... A diretora mesmo falou, né?, que se quiser ir pode ir...". (Genitora Fabíola)

“... Eu fui também na Escola esse ano, nesse dia que o Fabrício deu febre, depois quando ele voltou, eu levei ele porque tinha atestado médico de muitos dias, porque ele ficou afastado 15 dias (...) Por causa da pneumonia. Aí eu fui pra conversar com a professora, que a médica tinha passado as regrinhas pra evitar mais atividade, as coisas pra ele estar voltando... Aí eu fui também, fiquei o dia inteiro na Escola...". (Genitora Fabiola)

“... Eu já fui... Ixi, eu nem tenho muitas continhas, eu já fui lá muitas vezes (...) Eu vou lá direto, não, vou lá direto. Direto eu vou lá e... Aí eu falei até com a... Uma vez que eu fui lá, eu falei com uma professora, ela falou assim que ele [Artur] estava muito desobediente na sala de aula, não estava deixando nem a tia, sabe?, teimoso demais, não fazia tarefa e batia nos meninos e tal. Aí eu conversei com ele, fui lá conversei com a tia e tal. Aí depois eu voltei lá de novo pra perguntar se ele tinha melhorado, aí a tia falou assim que ele tinha melhorado, só que na hora do recreio ele estava jogando pedra nos meninos. Aí eu falei pra ela que... fui lá, voltei de novo, aí ela falou assim que ele estava 
mais ou menos, mas assim que estava... Aí eu falei pra ela que toda semana eu ia lá até ele...". (Genitora Adriana)

“... Eu vou porque eu resolvo ir mesmo. Tem vez que eu vou lá na cidade, igual uma vez eu fui lá na cidade, aí nós estávamos passando mais cedo, era umas quatro horas, cinco horas, aí eu falei assim: 'Adriano, vamos passar lá na Escola e vamos pegar os meninos de surpresa'...'. (Genitora Adriana)

Notamos que Fabíola mencionou que compareceu à instituição escolar nos primeiros dias de ida do filho para a Escola, bem como para dialogar com a professora de Fabrício sobre a necessidade de cuidados especiais com a criança na Escola, de acordo com prescrições médicas, tendo em vista o adoecimento da criança. Já Adriana afirmou que comparecia na instituição escolar, com frequência, para acompanhar o filho na Escola. De acordo com seus relatos, em tais momentos, houve a queixa da professora sobre o comportamento de Artur na Escola. Nas falas de Adriana, notamos a mobilização da família para acompanhar/solucionar problemáticas da criança no âmbito escolar - indicadas pela Escola - por meio de visitas à instituição.

Além das idas à Escola para acompanhar/obter informações sobre o filho no âmbito escolar, Adriana mencionou ainda que ocorreu seu comparecimento à instituição em um episódio ocorrido no transporte escolar, conforme consta no relato abaixo:

“... Esses dias no ônibus tinha umas meninas lá da granja lá que estava pegando na bunda dos meninos (...) Aí eu fui lá na Escola, falei pra elas (...) Aí eu fui lá na Escola e reclamei..., falei pra elas que que estava acontecendo dentro do ônibus e que se não parasse eu ia lá na casa da mãe delas... Aí a menina que fica lá [profissional da Escola], que é essa que eu esqueci o nome dela, falou que não, que era pra gente ficar despreocupada, né? Que ela ia conversar com as meninas e que se não resolvesse ia chamar a mãe delas. Aí parou...". (Genitora Adriana)

$\mathrm{Na}$ fala citada, percebemos que encontros entre família e Escola, por iniciativa dos pais, tinham também como intuito solucionar conflitos existentes entre as crianças no interior dos veículos escolares, ao longo do trajeto entre a Escola e as residências. Nessa situação, percebemos que Adriana indicou que, ao reivindicar a melhoria do atendimento da criança no transporte escolar, foi ouvida pela Escola, que solucionou a problemática relatada pela família.

Sobre a ida das famílias à Escola em momentos não organizados/planejados pela instituição escolar, Irene pontuou que os mesmos seriam autorizados pelos profissionais da Educação que afirmavam que a Escola estaria aberta para recebê-los, “... É aberto lá pra mim ir a hora que eu quiser ir. Tanto de manhã quanto a tarde. Eles falam 'O dia que vocês quiser vim aqui conversar com os professores vocês pode vir'...”. 
A análise das entrevistas indicou ainda que a Escola e os pais, além de se encontrarem no âmbito escolar, utilizavam outros instrumentos para comunicar-se, tais como bilhetes, conforme consta nos relatos a seguir:

“... Eles [profissionais da Escola] mandaram bilhete pra ir lá fazer a matrícula e eu fui...”. (Genitora Irene)

“... Como que fiquei sabendo [da reunião]? Elas avisaram. Elas mandaram o bilhetinho...”. (Genitora Flaviana)

“... O Fabrício teve febre esse ano na Escola, eles preferiu dar banho no Fabrício na Escola (...) Ele tinha um bilhetim que ela mandou pra mim...". (Genitora Fabiola)

“... A Escola só manda bilhete pra ir conversar quando acontece alguma coisa de grave lá...”. (Genitora Inês)

As famílias mencionaram que a Escola utilizava bilhetes para informar aos pais sobre a rematrícula da criança na instituição, sobre eventos realizados na mesma (como as reuniões), sobre o adoecimento da criança no âmbito escolar e sobre comportamentos da criança vistos como inadequados pela Escola. Em outro relato, a genitora de Iago ressaltou que a instituição escolar também utilizava o telefone para realizar queixas sobre a criança, “... Quando eu preciso eu que tenho que estar ligando, a Escola só me ligou acho que uma ou duas vezes durante esse ano inteiro pra reclamar do Iago...". Em tais relatos notamos que Inês teceu críticas aos momentos/motivos de a Escola comunicar com os pais e que estariam restritos a episódios problemáticos.

Sobre o uso do telefone para se comunicar com os pais, a genitora de Artur mencionou que a Escola não utilizava desta forma de comunicação:

“... Não, eles nunca me ligaram não. Sempre eles mandaram um recado pela minha menina, 'Fala pra sua mãe pra ela...'. Nunca falou pra eu ir lá não, sempre mandou recado pela minha menina, porque eu falo pra ela: 'Alice, pergunta lá pra tia como que tá o Artur e tal, fala pra tia isso, então é... Fala pra tia que se tiver precisando de alguma coisa, pra falar que eu compro e tal, se o lápis sumiu'... estes trem, mas eles nunca ligaram pra mim ir lá não...”. (Genitora Adriana)

No trecho apresentado, percebemos que Adriana apontou que a irmã de Artur era uma mediadora na relação Escola e família, ora levando mensagens da família para a instituição escolar, ora trazendo mensagens da Escola para a família. De acordo com Adriana, tal estratégia de comunicação seria utilizada pela família para obter informações sobre o cotidiano da criança na instituição escolar, “... eu falo pra ela: 'Alice, pergunta lá pra tia 
como que tá o Artur...". Em outro relato de Adriana evidenciamos que, diante do questionamento da família sobre o filho, a Escola enviava informações por Alice sobre o comportamento da criança:

“... Como minha menina estuda ali, então às vezes quando elas (profissionais da educação) precisam falar algum recado, então elas mandam pela menina, elas não me ligam e nem manda bilhetinho, né? Porque tem a menina, né? Aí [a Pamela] fala: 'Alice fala pra sua mãe pegar esse Artur e dar uns conselhos nele, dar umas varadas nele, conversar com ele que ele tá muito teimoso, muito desobediente' (...) Aí sempre eu mando perguntar pra mim: 'Alice pergunta lá a tia, como é que tá o Artur'. Às vezes ela fala, 'Nossa, agora não sei que que aconteceu com o Artur, o Artur tá tão bom e tal'. Agora tem época que 'Nossa, o Artur tá custoso demais, fala pra sua mãe que pelo amor de Deus, fala pra sua mãe vir aqui pra nós conversarmos'. Então, assim, elas têm comunicação com minha menina, né? Então o ano que vem, porque o ano que vem minha menina vai estudar de manhã e ele à tarde, então acho que não vai ter mais a menina pra dar o recado, então acho que elas vão comunicar através de ligação ou bilhetinho, né?...". (Genitora Adriana)

Segundo Adriana, a Escola comunicava-se com a família por meio de Alice informando à genitora sobre comportamentos do filho, avaliados pela profissional como ruins ou bons. Percebemos que a instituição escolar buscava intervir nas práticas familiares junto à criança, por meio de tais recados, incentivando a utilização, pela genitora de Artur, de meios democráticos (diálogo) mas também autoritários (castigos físicos) de educação. Notamos ainda que, em algumas circunstâncias, a Alice comunicava à família o pedido da Escola de comparecimento dos pais na instituição, tendo em vista os problemas comportamentais de Artur identificados pela professora. De acordo com Adriana, diante da possibilidade de comunicar com a família por meio de Alice, os profissionais de educação não utilizavam o telefone e bilhetes como forma de conversação entre Escola e família.

Adriana indicou ainda, em outra fala, que Alice realizou mediações entre a família e a Escola em casos que a genitora sugeriu mudanças em atividades realizadas pela professora junto a Artur, como a solicitação do envio de tarefas escolares para serem feitas na residência da criança, “... Eu falei pra Alice: 'Alice fala pra professora do Artur pra ela mandar uma tarefinha pro Artur todo o dia, mesmo que não seja uma tarefa, ao menos que seja pra ele fazer o nome dele numa folha pra ele saber que ele tem que fazer tarefa, porque ele tá muito preguiçoso, tá chorando em cima do caderno', ai ela falou assim, 'Não, mãe a tia falou assim que vai mandar'. Ai mandou algumas vezes...". Também nesse caso, percebemos a escuta de pedidos da família pela Escola.

Em outros relatos, notamos que a comunicação entre profissionais da Escola e famílias do campo ocorria ainda por meio do motorista do transporte escolar para a entrega de documentos solicitados pela Escola, “... mandou o trem [documentos pelo transporte escolar] 
pra gente assinar esses dias da rematrícula...” (Genitora Fabiola); “... A professora teve um dia que ela mandou até um papel pra mim levar o documento dos meninos lá, eu não pude [pela falta de transporte], e pedi o motorista pra levar pra mim (...) Aí ele levou. Elas ajeitou lá e mandou de novo..." (Genitora Flaviana).

Além de mediador entre famílias e profissionais da educação, consideramos que o encontro com o motorista escolar também se constituía como um momento de encontro das famílias do campo com a Escola, já que o motorista também era um profissional da mesma. $\mathrm{O}$ motorista apareceu, nas falas das famílias, como profissional com o qual as genitoras se relacionavam e que também tinha seu papel no cuidado/proteção/educação da criança. Tal relação, estabelecida entre famílias do campo e motoristas, foi indicada, pelos pais, como sendo às vezes de diálogo:

“... A van é boa, sabe? Porque igual, aqui passa o ônibus. O certo seria o ônibus pra elas ir (...) Então como lá na granja lá era a van que pegava, era Seu Moisés, não era esse rapaz agora não (...) Aí quando eu mudei ele falou assim: 'Oh, se a senhora quiser, eu continuo levando a Isa, porque como é caminho pra mim não tem... não tem diferença...’. Aí eu falei: 'Oh Seu Moisés, se o senhor não importar eu vou querer sim, porque além dela ser muito pequena, por que dentro do ônibus...'. Porque eu já andei dentro do ônibus eu... Igual quando a gente foi fazer a inscrição pras meninas, a gente foi no ônibus. Então o motorista tem que tá prestando atenção na rodovia e os meninos, é tudo bagunçado... É correndo um pra lá, outro pra cá... Aí eu falei pra... com Seu Moisés 'Se o senhor não importar, o senhor pode passar'. Aí ano passa... ano retrasado ele passou e esse ano ele continuou. Falou pra mim que ia continuar e continuou. Eu achei muito bom, porque na van é mais confortável pra elas, não tem espaço pra elas tá correndo, né? (...) É bem melhor...". (Genitora Irene)

“... É, o transporte assim, tá bom, né? Bom, bom, bom não está mas está bom. Porque eu consegui pôr ele na van, por que até então eles queriam, eles alegou que o Iago tinha que ir no ônibus. Só que o dia que eu fui fazer a matrícula dele eu fui no ônibus, né? Eu falei, 'Se for pro meu filho estudar nessa Escola dentro desse ônibus ele não estuda aqui', porque o ônibus não tem uma estrutura, não tem um cinto de segurança, os meninos ficam todos correndo pra lá e pra cá dentro do ônibus, o ônibus andando na rodovia... Falei 'Deus me livre e guarde! Se o motorista tiver que fazer uma freada brusca ou alguma coisa, vai vazar menino' (...) Falei 'Não deixo nunca'. Ai eu fui, conversei com o motorista da van, porque a Irene, você conversou, a filha dela, a Isa, já ia na van (...) Aí quando ela mudou pra cá eles falou que ela tinha que passar pro ônibus, que é o ônibus que passava aqui. Só que aí a gente foi, eu tive a ideia, 'Vamos conversar com o motorista, né?', foi o Seu Moisés... Aí foi o Seu Moisés falou que não, que ele passava aqui na porta tanto pra ir como pra voltar, falei 'Então não custa nada parar pra pegar aqui as criança'. Aí eu fui tal, conversei, fui e conseguimos (...) Aí até a Pâmela aqui que ia no ônibus, pequenininha também, eu consegui botar ela na van também. Porque a van é um carro menor, né? Eles não ficam correndo lá dentro, nem nada e tem o cinto de segurança, né? Então quer dizer, o risco - corre risco do mesmo jeito na rodovia - só que o risco é bem menor, né?, do que dentro do ônibus... ". (Genitora Inês)

Nos episódios narrados acima, notamos a existência do poder assumido/atribuído ao motorista do transporte escolar na relação Escola e família naquele contexto rural, caracterizado pela dependência das famílias do transporte viabilizado pela instituição escolar 
para que seus filhos tivessem acesso à Educação, tendo em vista a grande distância geográfica existente entre a Escola e suas residências. Segundo famílias, coube ao motorista do transporte escolar - mediante solicitação das genitoras de que seus filhos fossem na van, vista como mais segura e adequada para as crianças - decidir sobre a ida de Íris e Iago no veículo, ainda que a Escola tivesse indicado que tais crianças utilizassem o ônibus escolar, criticado pelos pais como sendo inapropriado para o transporte das crianças pequenas. Segundo as entrevistadas, o diálogo e a negociação com o motorista escolar - "Seu Moisés" - naquela circunstância foram bem-sucedidos, sendo que o mesmo ouviu e atendeu aos pedidos das famílias, havendo o estabelecimento de uma relação democrática entre os envolvidos.

No entanto, diante da mudança do motorista "Seu Moisés" para o "Moacir" para a realização do transporte escolar de Iago, Íris e Fabrício, notamos como a relação das famílias com a Escola/com este profissional tornou-se permeada por frustrações e tensões:

“... O transporte, tá bom, tá bem conduzido as criança... dependente do motorista (...) Você conheceu ele, o Moisés... Tratava as criança de mais bem, né? O Moacir, não sei se ele trata mal, não posso te afirmar isso porque eu nunca vi, eu nunca vi ele maltratar ninguém, mas não tem aquela conduta de ser bom condutor pra criança não. $O$ jeito dele... O jeito dele de conversar com a gente não é de ter paciência com criança não, Luciana (...) Eu acho fundamental uma pessoa que vai lidar com criança tanto professor, o diretor, o... até serviçal que vai fazer comida pra eles tem que gostar de criança, não é?, porque vai lidar com criança, ué. Tá o tempo todo com as crianças, né? E o motorista que, esse que está agora, pra mim não tem paciência...". (Genitora Fabíla)

“... O motorista não ajuda... Esses dias gritou com ele [Iago] e ele chegou muito nervoso aqui em casa... chorando demais, né? Então até com o próprio motorista eu já andei conversando, falando pra ele, né?, que eu estou pedindo 'Por favor, não grite com ele. Eu sei que às vezes vocês acham que o Iago é uma criança...', que tem muita gente que olha pro Iago acha que é uma criança sem educação, que tem que tratar na tapada, né? E não é assim...". (Genitora Inês)

Percebemos que as famílias teceram críticas ao motorista Moacir, indicando-o como sendo inadequado para realizar o transporte das crianças. Inês relatou como o motorista escolar, por meio de suas ações junto à criança, vinha interferindo, de forma equivocada, no processo de educação e desenvolvimento do filho. Ao realizar visitas à família de Fabrício, Fabíola relatou ainda que não concordava com a postura do motorista diante da família, pois, ao ir buscar e deixar as crianças em suas residências não dialogava com a genitora.

Nesse cenário, constatamos como o motorista foi indicado pelas famílias como importante profissional da Escola com o qual se relacionavam e, ainda, como mediador dos pais na relação com outros profissionais da instituição escolar. Em outros relatos, percebemos ainda que as famílias utilizavam outro instrumento para se relacionar com a Escola, sendo o 
mesmo a realização de intervenções junto à Prefeitura Municipal, para a melhoria do atendimento escolar oferecido às populações rurais, conforme indicam os relatos a seguir:

“... No início que começou o ano letivo a Escola estava tampada no meio de mato. E os dois funcionários que trabalham na limpeza (...) Ele contou pra nós que havia matado várias cobras lá na Escola. Aí eu vim embora doidinha. Por que eu fui os dois primeiros dias do Fabrício eu fui na Escola pra mim ver como é que era, porque eu não conhecia. Eles já tinham matado, nos primeiro dias de aula matado um punhado de cobra. Aí eu liguei pro Pedro [Secretário de limpeza da Prefeitura] $\boldsymbol{e}$ pedi pra ele, na quinta-feira, eles foi lá e arroçou...". (Genitora Fabíola)

“... Quando é época de poeira, que chega os transportes, as vans, os ônibus, aquilo lá tampa, some a Escola no meio da poeira. O Fabrício esse ano deu até pneumonia (...) Então, a Prefeitura pelo menos podia jogar um, um trem diferente lá. Agoá, o secretário da Prefeitura do município A não quis agoá pra mim, porque falou que não ia consegui agoá aquilo lá. Aí ele preferiu lavar a praça da cidade, do que agoá aquilo lá pra mim, que eu pedi. Pro Pedro (...) Eu falei com ele [Pedro] por telefone. Ele me ligou, me deu retorno aqui, eu conversei com ele. Duas vezes eu falei com ele, pra você ver o tanto que eu luto por aquela Escola...". (Genitora Fabíola)

Percebemos que Fabíola, mobilizada por uma preocupação com a segurança e saúde das crianças na Escola, relatou que havia solicitado junto à Prefeitura do município $A$ a realização de serviços na instituição. Tais falas indicam formas encontradas pela família de participação no cotidiano da instituição escolar, para a melhoria das condições do atendimento oferecido na Escola do campo. Tal aproximação do cotidiano escolar por meio da demanda de serviços junto à Prefeitura, além de indicar a defesa de uma concepção de que cabe ao Poder Público garantir uma Educação Infantil no campo com qualidade, evidenciou um protagonismo da família junto à Escola, o que pareceu, na fala de Fabíola, ser motivo de alegrias e orgulho para a genitora, “... Eu resolvi ir direto [na Prefeitura], depois comuniquei com a Vilma, falei: 'Eu que consegui arroçar a Escola pra vocês!' (...) Ah, ela nem acreditava, né? Uai, não tem mãe que luta pela Escola, agora vai eu...”. A busca pela visibilidade da família no contexto escolar também foi evidenciada nas falas dessa genitora.

Dessa forma, constatamos que os instrumentos da relação Escola e família eram diversos. Apesar do uso dos mesmos, famílias indicaram ainda que havia na Escola a ausência de momentos e espaços para a discussão/troca de informações sobre as atividades realizadas na instituição escolar junto às crianças da Educação Infantil, “... Não, fico não [sabendo das atividades realizadas na Escola com as crianças] (...) Não teve não [momentos para discussão de tais atividades]..." (Genitora Adriana). As famílias relataram desconhecer as atividades realizadas pelos filhos na Escola, “... Eu não sei te falar realmente assim o que que ele faz o que que deixa de fazer..." (Genitora Inês), e afirmaram que o conhecimento das atividades realizadas na Escola, e também do perfil dos professores, ocorria muitas vezes a partir da 
escuta da criança, “... Não, que eu tenho conhecimento que eles fazem eles brincam lá na Escola, né? Tem muita brincadeira que ele chega aqui e conta..." (Genitora Fabiola).

A falta de diálogos entre Escola e família sobre outras nuanças do atendimento também foi indicada por Fabíola:

“... O transporte é muito importante você saber quem é o motorista que está carregando seu filhou! Numa BR perigosa dessa aí, já houve casos de eu ficar preocupada, você vê acidente no horário, você vê, você escuta um bombeiro um trem qualquer, está no horário do seu filho ir você não preocupa? (...) Aí você tem que saber o telefone do seu motorista pra você perguntar... Igual esses dias a gente não está sabendo, porque o motorista que está trazendo a tarde é outro (...) Não sei (...) E foi feito sem comunicar pra gente, a troca também. Sem comunicar...". (Genitora Fabíola)

Percebemos que a genitora criticou o silenciamento da Escola diante da troca de motorista da criança. Para Fabíola, tal situação demandava uma maior conversa entre pais e Escola, tendo em vista as características do transporte de crianças, naquele meio rural, que trazia perigos no deslocamento das crianças e possibilidades de acidentes.

Dessa forma, genitoras entrevistadas indicaram o desejo de que Escola e famílias estabelecessem uma relação mais próxima, para que estas tivessem mais informações sobre a instituição e sobre acontecimentos envolvendo a criança no âmbito escolar.

A partir das discussões realizadas acima, percebemos que as famílias do campo indicaram a existência e uso de diversos instrumentos na relação Escola e família. Nas falas das famílias, pudemos apreender que o uso dos instrumentos cumpriria diferentes objetivos para a Escola e para as famílias. Para a instituição escolar, os mesmos seriam um meio para: realizar matrícula da criança; informar aos pais sobre o atendimento na Escola; informar a família sobre desempenho e problemas de saúde e comportamento da criança na instituição escolar; e intervir nas práticas familiares de educação da criança. Para as famílias, segundo as entrevistadas, tais instrumentos seriam um meio dos familiares: entregar documentos para a Escola; conhecer a instituição e auxiliar a criança no processo de adaptação à mesma; solicitar à Escola solução de conflitos existentes entre as crianças no interior dos veículos escolares; solicitar à Escola modificações nas práticas pedagógicas junto à criança; acompanhar/obter informações sobre a criança e seu cotidiano na Escola e conversar sobre o estado de saúde ou problema de comportamento da criança indicados pela Escola.

Segundo famílias, nas reuniões, um dos instrumentos de encontro entre a Escola e as famílias, ocorria o fornecimento de informações, pelas profissionais, sobre o atendimento na 
Escola e, ainda, a entrega de notas das crianças do Ensino Fundamental. A ida das famílias às reuniões foi citada como sendo irregular por algumas das genitoras e inexistente por outras, devido à distância entre a Escola e as residências das famílias e à falta do transporte. Houve entrevistadas que mencionaram que compareceram às reuniões escolares, mesmo não possuindo veículo próprio. No entanto, apesar de indicarem que o encontro entre família e Escola (não)ocorria em tais reuniões, apreendemos, nas falas das famílias, que os principais instrumentos da relação Escola e família seriam outros, tais como a irmã da criança da Educação Infantil (mediadora nesta relação) e a ida da família à Escola por solicitação da instituição ou por desejo/iniciativa da mesma. A ida da família à instituição escolar em momentos não organizados pela Escola foi mencionada como sendo frequente por entrevistadas que buscavam superar dificuldades impostas pelas condições geográficas do campo (distância Escola e família), pela política do município (ausência de transporte escolar para os pais) e pelas condições de vida (falta de veículo próprio das famílias), recorrendo a outras formas para estarem presentes na Escola, como, por exemplo, a pé ou por mototáxi, nos horários possíveis para as mesmas.

A ida das famílias, em momentos não organizados pela Escola, foi indicada, pelas entrevistadas, como sendo aceita pela instituição escolar, vista pelas famílias como aberta à presença das mesmas. Tais encontros parecem expressar uma tentativa da família de compartilhar o cuidado e educação da criança com a Escola, na medida em que os mesmos ocorriam, segundo entrevistadas, para que as famílias pudessem conhecer a instituição escolar, bem como discutir, acompanhar e resolver questões relativas ao cuidado e à educação dos filhos ao longo do ano, indo além do que, segundo Irene, a Escola propunha na maioria dos encontros com as famílias: a resolução de problemáticas ocorridas no âmbito escolar.

Como forma de sistematização de tais dados, construídos nas entrevistas com as famílias, apresentamos o quadro a seguir: 


\begin{tabular}{|c|c|c|}
\hline $\begin{array}{c}\text { Instrumentos } \\
\text { da relação } \\
\text { Escola e } \\
\text { família }\end{array}$ & Final & $\begin{array}{c}\text { Como ocorria a relação Escola e } \\
\text { famílias com o uso dos } \\
\text { instrumentos }\end{array}$ \\
\hline Reuniões & \multirow{9}{*}{$\begin{array}{l}\text { - Escola: } \\
\text { - Entregar notas. } \\
\text { - Informar sobre o atendimento na instituição. } \\
\text { - Realizar rematrícula. } \\
\text { - Informar problemas de saúde e comportamento da } \\
\text { criança. } \\
\text { - Intervir nas práticas familiares de educação da } \\
\text { criança. } \\
\text { - Família: } \\
\text { - Conhecer a Escola e auxiliar a criança no } \\
\text { processo de adaptação à mesma. } \\
\text { - Entregar documentos. } \\
\text { - Solicitar solução de conflitos existentes entre as } \\
\text { crianças no interior dos veículos escolares. } \\
\text { - Solicitar modificações nas práticas pedagógicas. } \\
\text { - Acompanhar/obter informações sobre a criança e } \\
\text { seu cotidiano na Escola. } \\
\text { - Conversar sobre estado de saúde ou problema de } \\
\text { comportamento da criança indicado pela Escola. } \\
\text { - Prefeitura: } \\
\text { - Melhorar a qualidade do atendimento da Escola. }\end{array}$} & \multirow{9}{*}{$\begin{array}{l}\text { Relação entre pais e profissionais } \\
\text { era estabelecida com a presença das } \\
\text { famílias na Escola, a partir da } \\
\text { mobilização dos mesmos para irem à } \\
\text { instituição. } \\
>\text { Relaçãa era estabelecida devido à } \\
\text { mobilização da Escola para receber os } \\
\text { pais e para se comunicar com os } \\
\text { mesmos, por meio da abertura da } \\
\text { Escola e uso de diversos instrumentos. } \\
>\text { Relação dificultada devido à } \\
\text { distância geográfica entre Escola e } \\
\text { famílias e falta de transporte para/dos } \\
\text { pais. } \\
>\text { Relação era restrita às situações } \\
\text { problemáticas envolvendo a criança. } \\
>\text { Relação era estabelecida tendo em } \\
\text { vista a busca, pelas famílias, de } \\
\text { conhecer a Escola e discutir, } \\
\text { acompanhar e resolver questões } \\
\text { relativas ao cuidado e à educação da } \\
\text { criança. } \\
>\text { Relação era estabelecida pela busca } \\
\text { da família por melhoria do atendimento } \\
\text { oferecido na Escola. }\end{array}$} \\
\hline $\begin{array}{l}\text { Festas e } \\
\text { eventos }\end{array}$ & & \\
\hline & & \\
\hline Telefo & & \\
\hline $\begin{array}{l}\text { Irmã da } \\
\text { Criança }\end{array}$ & & \\
\hline $\begin{array}{l}\text { Motorista } \\
\text { escolar }\end{array}$ & & \\
\hline $\begin{array}{l}\text { Ida da família } \\
\text { à Escola por } \\
\text { solicitação da } \\
\text { instituição }\end{array}$ & & \\
\hline $\begin{array}{l}\text { Ida da família } \\
\text { à Escola por } \\
\text { iniciativa das } \\
\text { famílias }\end{array}$ & & \\
\hline $\begin{array}{l}\text { Contato com a } \\
\text { Prefeitura } \\
\text { Municipal }\end{array}$ & & \\
\hline
\end{tabular}

Quadro 23 - Instrumentos da relação Escola e família - Relatos das famílias

A partir da visualização do quadro acima, percebemos que as famílias do campo mencionaram elementos que atravessavam e dificultavam a relação Escola e família, sendo os mesmos: características do campo (distância geográfica), características do município (não disponibilização de transporte escolar para os pais), características das famílias rurais (precárias condições econômicas) e características da Escola (momentos estabelecidos para se relacionarem com as famílias).

As famílias indicaram a abertura da Escola para a família e a existência da participação dos pais no âmbito escolar, apesar dos dificultadores citados acima. Evidenciamos, nas falas das famílias, uma mobilização para irem à Escola, acompanharem as práticas escolares de cuidado e educação da criança e contribuírem com a melhoria da qualidade do serviço oferecido pela instituição. Ainda assim, famílias ressaltaram que tal participação era aquém da desejada. 


\subsubsection{Aproximações e distanciamentos das significações das profissionais e famílias sobre os instrumentos da relação entre a Escola e as famílias do campo}

A partir da análise das falas das profissionais de educação e das famílias, verificamos que as entrevistadas indicaram a existência e utilização de diversos instrumentos na relação Escola e família, sendo os mesmos: reuniões; festas e eventos; bilhetes; telefone; motorista escolar; ida das famílias por solicitação da Escola e por iniciativa das mesmas. Tanto profissionais como famílias citaram o uso de crianças como mediadoras da relação Escola e família, no entanto, famílias indicaram a irmã da criança da Educação Infantil, já as profissionais indicaram a própria criança da Educação Infantil como sendo mediadora das instituições escolar e familiar.

Ao analisarmos pesquisas realizadas em instituições de Educação Infantil urbanas (BHERING; NEZ, 2002; MEIRA, 2004; CÔRREA, 2006; SAISI, 2010), observamos que a ida das famílias nos momentos de entrada e saída das crianças foi um dos meios utilizados de encontro entre profissionais e famílias em instituições localizadas nas cidades e que não foi mencionado na nossa pesquisa (já que as crianças iam para a Escola Flamboyant no transporte escolar). No entanto, o uso do motorista do transporte escolar e da própria criança como mediadora da relação Escola e família despontou como importantes instrumentos desta relação no campo investigado e que não foram encontrados nos estudos mencionados.

Nas pesquisas citadas acima, notamos ainda que a realização de reuniões entre pais e profissionais constituiu-se um dos principais instrumentos para a promoção da relação Escola e família. Na nossa investigação, nos chamou a atenção o foco também dado pelas profissionais da Escola Flamboyant às reuniões como sendo um dos principais meios de encontro com as famílias, o que parece indicar uma aproximação com modelos preestabelecidos (diríamos citadinos) de estabelecimento da relação Escola e família. Contudo, nas falas das famílias da Escola Flamboyant, outro instrumento destacou-se como sendo relevante e cumprindo funções significativas para os pais, sendo o mesmo a ida dos familiares em momentos não organizados pela Escola, por solicitação da instituição ou por desejo, necessidade das famílias, nos momentos possíveis para as mesmas.

No que tange às significações construídas pelas entrevistadas sobre as finalidades do uso dos instrumentos citados na relação Escola e família, percebemos que as mesmas ora se aproximaram, ora se afastaram, conforme consta no quadro a seguir: 


\section{Finalidades da utilização dos instrumentos}

\begin{tabular}{|c|c|}
\hline Profissionais & Famílias \\
\hline Escola realizar rematrícula. & Escola realizar rematrícula. \\
\hline $\begin{array}{l}\text { Escola entregar notas. } \\
\end{array}$ & Escola entregar notas. \\
\hline $\begin{array}{c}\text { Escola informar sobre problema de comportamento } \\
\text { da criança. }\end{array}$ & $\begin{array}{l}\text { Escola informar sobre problemas de comportamento } \\
\text { da criança. }\end{array}$ \\
\hline Escola informar sobre $\mathrm{o}$ atendimento na instituição. & Escola informar sobre o atendimento na instituição. \\
\hline Família opinar sobre o atendimento. & 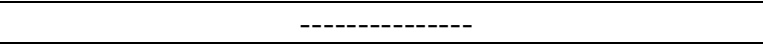 \\
\hline Escola discutir com pais orçamento escolar. & --------------- \\
\hline Escola informar sobre acidente da criança. & 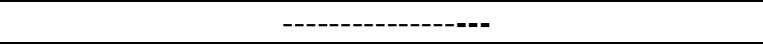 \\
\hline 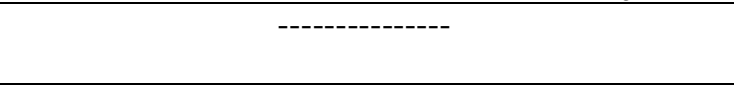 & $\begin{array}{c}\begin{array}{c}\text { Escola intervir nas práticas familiares de educação da } \\
\text { criança. }\end{array} \\
\end{array}$ \\
\hline 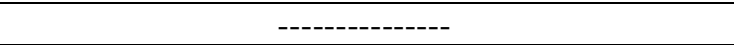 & Escola informar sobre problemas de saúde da criança. \\
\hline ------------- & $\begin{array}{l}\text { Família conhecer a Escola e auxiliar a criança no } \\
\text { processo de adaptação à mesma. }\end{array}$ \\
\hline 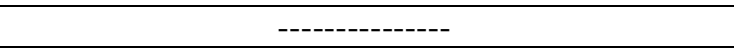 & Família entregar documentos. \\
\hline --------------- & $\begin{array}{l}\text { Família solicitar à Escola solução de conflitos } \\
\text { existentes entre as crianças no interior dos veículos } \\
\text { escolares. }\end{array}$ \\
\hline --------------- & $\begin{array}{c}\text { Família solicitar à Escola modificações nas práticas } \\
\text { pedagógicas junto à criança. }\end{array}$ \\
\hline ------------- & $\begin{array}{c}\text { Família acompanhar/obter informações sobre a } \\
\text { criança e seu cotidiano na Escola. }\end{array}$ \\
\hline -------------- & $\begin{array}{l}\text { Família conversar sobre estado de saúde ou problema } \\
\text { de comportamento da criança indicado pela Escola. }\end{array}$ \\
\hline $\begin{array}{l}\text { Prefeitura melhorar qualidade do atendimento da } \\
\text { Escola. }\end{array}$ & $\begin{array}{l}\text { Prefeitura melhorar a qualidade do atendimento da } \\
\text { Escola. }\end{array}$ \\
\hline
\end{tabular}

Quadro 24 - Instrumentos da relação Escola e família (Finalidades) - Relatos das profissionais e famílias

Tanto para famílias como para profissionais, os instrumentos da relação entre Escola e famílias teriam como objetivos: possibilitar a realização da matrícula da criança na instituição; entregar notas das crianças do Ensino Fundamental; comunicar aos pais sobre problemas de comportamento do filho no âmbito escolar e sobre aspectos do atendimento na instituição, tais como suas regras; solicitar intervenções da Prefeitura no âmbito escolar para a melhoria do atendimento. Tais finalidades parecem se relacionar com aspectos de gestão e atendimento da Escola e relativos à criança, mais especificamente à sua matrícula, desempenho e comportamento na instituição escolar.

No entanto, para as profissionais, tais instrumentos possibilitariam ainda a discussão do orçamento escolar, a comunicação sobre acidente da criança na Escola e a escuta das opiniões das famílias sobre o atendimento. Tais finalidades não foram mencionadas pelas famílias como estando presentes nos momentos de encontro entre Escola e família. Conforme será discutido no item 5.5. Situações problemáticas na relação entre a Escola Flamboyant e as famílias do campo, famílias queixaram-se da falta de informações sobre acidentes ocorridos com a criança na Escola. 
Notamos ainda que, para as famílias do campo, o uso dos instrumentos teriam diversas finalidades - para além da questão da matrícula, desempenho e comportamento da criança não mencionadas pelas profissionais, tais como: possibilitar à Escola informar sobre problemas de saúde da criança e intervir nas práticas familiares de educação da criança; permitir às famílias demandar à Escola solução de conflitos envolvendo o filho; solicitar modificações nas práticas pedagógicas da Educação Infantil e acompanhar o filho no dia a dia escolar. Nas falas das famílias, notamos que o uso de diferentes instrumentos na relação Escola e família parecem significar, para as famílias, uma tentativa de conhecer a Escola e o cotidiano do filho na mesma, bem como uma busca pelo compartilhamento do cuidado e à educação do filho com a instituição escolar. Tais tentativas de compartilhamento parecem não ser constatadas pela Escola, ainda que profissionais da instituição escolar busquem, segundo relatos das profissionais e famílias, ouvir e atender às solicitações dos pais relativas ao cuidado e à educação da criança (Exemplos: Envio de tarefas para serem feitas em casa. Intervenção da Escola em conflitos entre as crianças no transporte escolar). Ressaltamos, ainda, que a mobilização das famílias para compartilhar a educação da criança com a Educação Infantil, por meio do uso de diversos instrumentos, não foi algo encontrado em estudos (urbanos), discutidos anteriormente. Houve pesquisas que indicaram que as famílias adotavam uma posição de passividade frente à Escola e de pouco interesse em conhecer o que a instituição oferecia em termos pedagógicos e sociais (BHERING, NEZ; 2002); enquanto outros estudos mencionaram que os pais possuíam o interesse em conhecer e participar do cotidiano da criança na Escola, mas que possuíam receios de fazê-lo (MEIRA, 2004).

$\mathrm{Na}$ nossa investigação evidenciamos que contribuía para a possibilidade de pais irem à Escola, segundo famílias e profissionais, o fato de a Escola se colocar como aberta à família e mobilizada na busca por encontrar e conversar com as famílias atendidas. No entanto, nas falas das profissionais, a mobilização das famílias para a construção da relação Escola e pais é vista como precária. Profissionais defenderam a ideia de que pais teriam desinteresse em relação à Escola. Já as famílias, em seus relatos, apesar de indicarem suas ausências em reuniões e eventos na Escola, justificadas pela distância geográfica e falta de transporte, indicaram que sua ida à Escola seria frequente, porém em outros momentos, e demonstraram uma grande mobilização para irem à mesma.

Tais afastamentos e aproximações das significações das entrevistadas sobre a relação Escola e família são indicados no quadro, a seguir, que também apresenta outros dados sobre a temática: 


\begin{tabular}{|c|c|}
\hline \multicolumn{2}{|c|}{ Como ocorria a relação Escola e famílias com o uso dos instrumentos } \\
\hline Profissionais & Famílias \\
\hline $\begin{array}{l}\text { Relação não era estabelecida devido à não } \\
\text { mobilização e presença das famílias na Escola, } \\
\text { havendo a ida de poucos pais à instituição. }\end{array}$ & --------------- \\
\hline - -------------- & $\begin{array}{l}\text { Relação entre pais e profissionais era estabelecida } \\
\text { com a presença das famílias na Escola, a partir da } \\
\text { mobilização dos mesmos para irem à instituição. }\end{array}$ \\
\hline $\begin{array}{l}\text { Relação era estabelecida devido à mobilização da } \\
\text { Escola para receber os pais e para se comunicar } \\
\text { com os mesmos, por meio da abertura da Escola e } \\
\text { uso de diversos instrumentos. }\end{array}$ & $\begin{array}{c}\text { Relação era estabelecida devido à mobilização da } \\
\text { Escola para receber os pais e para se comunicar } \\
\text { com os mesmos, por meio da abertura da Escola e } \\
\text { uso de diversos instrumentos. }\end{array}$ \\
\hline $\begin{array}{c}\text { Relação era distanciada devido à distância } \\
\text { geográfica entre Escola e famílias e falta de } \\
\text { transporte dos pais. }\end{array}$ & $\begin{array}{l}\text { Relação dificultada devido à distância geográfica } \\
\text { entre Escola e famílias e falta de transporte dos } \\
\text { pais. }\end{array}$ \\
\hline $\begin{array}{l}\text { Relação era distanciada devido a desinteresse da } \\
\text { família. }\end{array}$ & - -------------- \\
\hline $\begin{array}{l}\text { Relação era desgastada devido ao formato das } \\
\text { reuniões realizadas na Escola. }\end{array}$ & --------------- \\
\hline $\begin{array}{c}\text { Relação era restrita devido ao pouco tempo } \\
\text { disponível para professores conversarem com pais } \\
\text { nas reuniões. }\end{array}$ & --------------- \\
\hline - -------------- & $\begin{array}{c}\text { Relação era restrita às situações problemáticas } \\
\text { envolvendo a criança. }\end{array}$ \\
\hline
\end{tabular}

Conforme consta no quadro apresentado, profissionais citaram ainda outros elementos que contribuiriam para dificultar a relação Escola e família, não mencionados pelas famílias, e que seriam: o formato desgastante das reuniões e que tornava o tempo para pais e professores conversarem escasso. Já as famílias, apesar de não mencionarem tais características das reuniões promovidas na Escola, nas quais relataram estar pouco presentes, queixaram-se que a relação da Escola com os pais ficava restrita à solução de problemáticas. Tanto para famílias como para profissionais a grande distância geográfica entre Escola e as residências das famílias contribuía para dificultar a relação entre as instituições familiar e escolar.

A partir do exposto acima, percebemos que as significações das profissionais e das famílias ora se aproximaram e ora se afastaram, quando houve a discussão dos instrumentos da relação Escola e família. Notamos que tanto famílias como profissionais relataram o uso de instrumentos semelhantes na relação Escola e pais. No entanto, profissionais pareceram dar mais destaque para as reuniões, enquanto as famílias enfatizaram a ida dos pais em momentos não organizados pela Escola. 
No que se refere às finalidades do uso dos diferentes instrumentos na relação Escola e família, percebemos que as significações das profissionais e famílias se afastaram e se aproximaram, conforme representado nas figuras a seguir:

\section{Significações aproximaram-se}

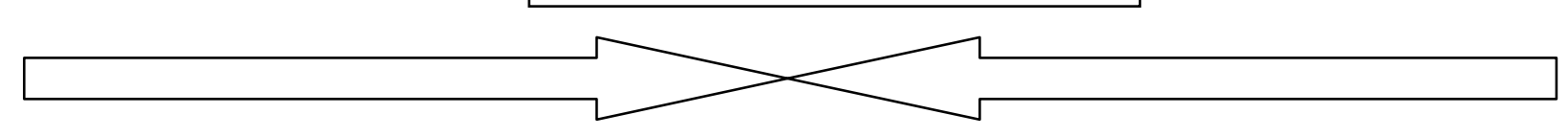

- A aproximação das significações das profissionais em relação às significações das famílias ocorreu em momentos nos quais mencionam que a utilização dos instrumentos na relação Escola e família teria finalidades relacionadas com aspectos da gestão e atendimento da Escola e com a matrícula, desempenho e comportamento da criança na instituição escolar. Consideramos que tais aproximações são importantes e indicam que famílias e profissionais visualizam os mesmos objetivos que atravessariam alguns de seus encontros, ainda que possam não concordar com os mesmos.

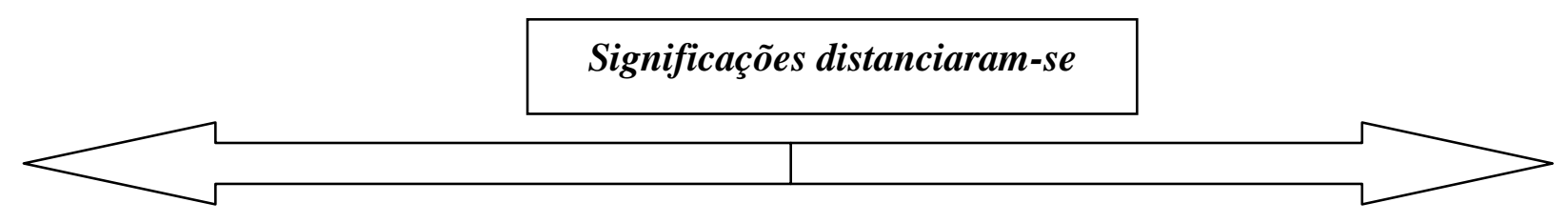

- O distanciamento das significações das profissionais em relação às significações das famílias pareceu ocorrer em momentos que:

- As profissionais mencionam finalidades na utilização dos instrumentos que não foram indicadas pelas famílias e relacionadas às reuniões escolares.

- As famílias mencionam finalidades na utilização dos instrumentos que não foram indicadas pelas profissionais, estando tais objetivos mais relacionados às circunstâncias em que os pais iam à Escola em momentos não organizados por esta instituição.

Tais diferenças nas finalidades dos encontros entre Escola e família podem contribuir para a fragilização da relação entre as instituições familiar e escolar. O fato de a família não vivenciar o que a Escola propõe nos encontros com os pais (pela impossibilidade de ir à Escola, dentre outros motivos) e de a Escola não visualizar a forma como a família deseja e vem buscando a relação com a instituição escolar (forma esta que se aproxima da ideia de compartilhamento do cuidado e educação da criança) pode gerar desencontros de pais e profissionais na relação Escola e família. 
Com a discussão dos instrumentos da relação Escola e família e suas finalidades, profissionais e famílias também construíram significações sobre a relação Escola e família a partir do uso dos instrumentos. Tais significações das profissionais e famílias também se aproximaram e distanciaram, conforme indicam as figuras a seguir:

\section{Significações aproximaram-se}

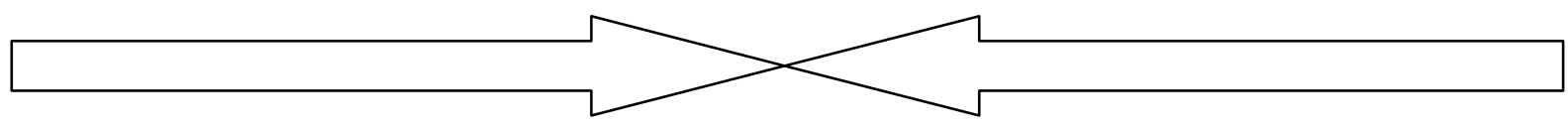

- A aproximação das significações das profissionais em relação às significações das famílias pareceu se relacionar com momentos em que dialogam com características dos contextos nos quais estão a Escola e as famílias para discutirem os instrumentos da relação entre as instituições escolar e familiar. Tanto profissionais como as famílias mencionaram que características do município (não disponibilização do transporte escolar para os pais), características do campo (distâncias geográficas) e características das famílias (precárias condições de vida - falta de transporte) contribuíram para dificultar a relação Escola e família. As significações das profissionais e famílias se aproximaram ainda quando reconheceram, a partir de saberes construídos na vivência na e com a Escola, a mobilização e o papel desta instituição para comunicar e se relacionar com os pais, por meio do uso de diferentes instrumentos e de sua abertura à presença das famílias no âmbito escolar. 


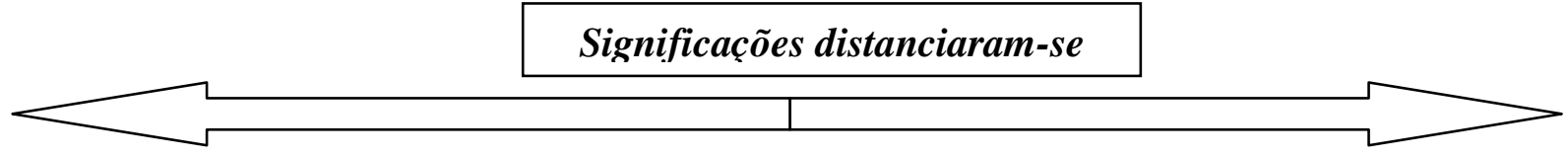

- O distanciamento das significações das profissionais em relação às significações das famílias pareceu se relacionar principalmente com momentos em que as profissionais dialogam com concepções sobre família rural e pobre, presentes na matriz sócio-histórica, para discutir os instrumentos da relação Escola e família. Nesta discussão, aliando-se às significações gerais e negativas sobre família do campo e popular, as profissionais indicaram a ida e participação dos pais no âmbito escolar como sendo precárias e a relação Escola e família como sendo distanciada. Já as famílias, dialogaram com elementos do contexto rural e recorreram às suas vivências concretas junto à Escola para a discussão sobre os instrumentos da relação Escola e família. Os pais apontaram sua presença no âmbito escolar como sendo constante, apesar das dificuldades enfrentadas para irem à Escola. Tais dificuldades, para as famílias, tornava a presença dos pais aquém da desejada mas não a inviabilizava totalmente.

Dessa forma, a vivência na Escola e o conhecimento que as profissionais relataram ter das famílias (como a respeito de suas condições socioeconômicas) contribuíam para a construção de significações atreladas à realidade do campo e semelhantes às construídas pelas famílias. No entanto, a ausência de um conhecimento mais aprofundado das famílias atendidas contribuía para que profissionais se ancorassem em (pré)concepções construídas socialmente sobre as famílias populares e rurais.

A nosso ver, tais distanciamentos nas significações de profissionais e famílias indicam discrepâncias na forma como profissionais e famílias veem seus momentos de encontros, bem como sobre o que esperam e desejam dos mesmos. Apontam ainda para um desconhecimento da Escola sobre concepções e metas das famílias do campo no que tange à Escola e à educação de seus filhos, na medida em que se baseiam em discursos mais gerais sobre as famílias pobres e do campo e não em saberes já construídos sobre a comunidade atendida e seu envolvimento com a Educação das crianças. 


\subsection{A RELAÇÃO ESCOLA E FAMÍLIAS E AS DISTÂNCIAS GEOGRÁFICAS NO CAMPO}

Ao falarem sobre os instrumentos da relação Escola e família, entrevistadas foram indicando em suas falas que um dos elementos que atravessava tal relação é a grande distância geográfica existente entre as instituições familiar e escolar.

Ao analisarmos os relatos das profissionais e famílias, notamos que a distância geográfica apareceu associada a outros elementos, como características do município, da Escola e das famílias, na discussão da relação Escola e família.

Nos próximos itens, buscamos discutir significações das entrevistadas sobre como as distâncias geográficas, somadas aos elementos citados acima, configuravam a relação entre as instituições familiar e escolar.

\subsubsection{Significações das profissionais sobre a relação Escola e famílias e as distâncias geográficas no campo}

Segundo profissionais da Escola, a grande distância geográfica entre as instituições familiar e escolar contribuiria para um distanciamento entre pais e profissionais:

“... A diferença que eu notei aqui assim [de EMEI da cidade], eu não gostei muito não, mas por ser, as residências serem de difícil acesso e longe (...) Não é uma relação direta com os pais (...) Eu acho que a família estando na Escola todo o dia facilita mais a convivência do que igual aqui a gente não vê eles de jeito nenhum (...) [Facilita] Esse contato com a família, que aqui não tem...". (Profissional Poliana)

De acordo com Poliana, a distância geográfica e as condições de acesso às residências das famílias faziam com que a relação Escola e pais não fosse cotidiana e "direta", como ocorre em instituições localizadas na cidade, o que, na visão da entrevistada, dificultaria tal relação. A distância física é indicada, dessa forma, como importante elemento que configura a relação Escola e família no campo e, ainda, que a diferencia da relação existente entre Escola e família na cidade.

Para profissionais, tendo em vista as distâncias geográficas no campo, a não disponibilização do transporte escolar contribuiria para fragilizar a relação da Escola com os pais: 
“... É raro [momentos de encontro com as famílias], porque, o quê que acontece? De primeiro poderia usar o transporte pra vir (...) O motorista podia dar carona... É... a Prefeitura até cedia o transporte de reunião. Agora cortou... Então vem pro... vem pra Reunião de Pais ou vem pra Escola aquele pai que pega uma carona, ou que vem de a pé, ou que... Pode ver aqui oh... Nós estamos aqui o dia todo, apareceu essa menina, né? Que é mãe de aluno, tá de carro, né? (...) Chegou uma de a pé, você viu? (...) É... passou uma mulher aqui perto (...) São poucos. O contato com os pais ficou muito restrito...". (Profissional Vilma)

Vilma afirmou que em outros períodos o transporte era disponibilizado, pela Prefeitura municipal, para os pais irem à Escola Flamboyant. A entrevistada pontuou que a falta de transporte para os pais comparecerem às reuniões, promovidas pela e na instituição escolar, contribuía para o distanciamento entre a Escola e as famílias. Vilma indicou que, diante das distâncias físicas e ausência do transporte escolar para as famílias, alguns pais buscavam utilizar outras estratégias para ir às reuniões, como a pé ou de carona.

Ao falar sobre esta temática Dirce pontuou que, no período que o transporte escolar era oferecido pelo município, havia uma maior participação dos pais no âmbito escolar. A profissional indicou ainda que a Escola Flamboyant, juntamente com outras instituições do campo do município A, vinha solicitando junto à Prefeitura Municipal o oferecimento às famílias do campo do transporte escolar:

"... O que a gente [diretoras] luta lá [Prefeitura Municipal] é pra eles liberarem pelo menos quatro vezes no ano, para quatro reuniões (...) Já fez documentos, pedindo pra eles liberarem ao menos quatro vezes por ano (...) Mas eles têm o problema do seguro, né? Que tem o órgão PENAD que acompanha o transporte escolar, então tem o caso do seguro... Então se acontecer um acidente, tiver um pai que não é... Porque quem é assegurado são as crianças, né? E se tiver um pai lá dentro, aí prejudica todo mundo porque já tava fora da... A gente sabe que a Prefeitura não pode abrir por causa de..., né?, regras e leis que ela tem que seguir, né?, de um órgão maior que está superior a ela, né? (...) Um órgão do governo federal. O transporte é do aluno, o aluno tem o seguro de vida, o aluno tem o cadastro, tem que fazer o cadastro dele no transporte, então se algum pai vai para ali e vai para lá, tá irregular e se acontece um acidente em uma coisa irregular... tem as consequências para a Prefeitura, né? (...) Deus o livre, se algum pai morrer aí dentro de um ônibus que é só escolar, com cadastro só de alunos, né?...". (Profissional Dirce)

Na fala de Dirce, notamos que a falta do transporte escolar se constituía como uma problemática também para outras Escolas, no campo do município, que buscavam resolver tal situação junto ao Poder Público municipal. No entanto, segundo a entrevistada, devido às legislações nacionais que regulamentam a questão do transporte escolar e do seguro dos passageiros nos veículos, não seria possível à Prefeitura oferecer o transporte aos pais, já que isto se constituiria uma irregularidade do ponto de vista jurídico, tendo em vista que somente as crianças estariam asseguradas. 
Sobre a não viabilização do transporte escolar para os pais do campo pelo Poder Público, outra profissional afirmou que tal situação seria justificada de outra forma por profissionais da Prefeitura:

“... Até um dia, o chefe do transporte, que eu falei assim, 'Ah, não... vocês é ruim demais, porque que não libera o transporte pra esses pais vir, pelo menos uma vez no bimestre e tal?'. Ele falou assim, 'Se você for na casa desse pessoal, você vai ver que todo mundo tem, nem que seja, um carrinho velho lá' (...) 'Eles têm pelo menos um carrinho lá guardado, mas que que eles fazem? 'Ah pra ir pra Escola eu não vou pôr gasolina pra ir'. Agora fala pra eles que tem uma festa na casa do fulano, que eles vão pra festa'. Então assim, acho que a gente abraça muito a causa do pessoal, né? Então, se a gente for pensar também o povo tem muito disso, né?...”.

Notamos que a profissional também indicou a realização da solicitação de transporte escolar para as famílias do campo junto ao Poder Público. No entanto, de acordo com a entrevistada, um dos profissionais da Prefeitura (chefe de transporte), diante de tal solicitação, argumentou que o oferecimento do transporte escolar para as famílias do campo poderia configurar uma prática paternalista já que as mesmas teriam veículo próprio e condições de locomoção. Segundo a entrevistada, o profissional da Prefeitura apontou que a não ida dos pais do campo à Escola se daria por um desinteresse dos mesmos/uma opção já que as famílias do campo iriam para outros locais e eventos, como festas nas residências de colegas. No relato citado, a profissional se moveu em direção aos argumentos apresentados na fala do profissional da Prefeitura Municipal, “... Então, se a gente for pensar também o povo tem muito disso, né?...". Nesse contexto, configura-se uma visão da família do campo como sendo, por vezes, desinteressada e descompromissada em relação à Escola. A profissional pontuou, porém, que o transporte deveria ser oferecido para os pais:

“... É, eu acho que deveria ter o transporte também, né?, acho que pro pai estar usando e tudo, né? Hoje eles usam isso como argumento. Eu ligo lá, 'Pai, oh seu filho tá assim, assim eu preciso de você aqui', 'Mas como que eu faço? Não tem transporte', né?, acaba agarrando nisso, né?...".

A profissional de educação, nesse momento, ao indicar a necessidade de oferecimento do transporte escolar para os pais, parece expressar um movimento de colocar-se no lugar das famílias e auxiliá-las na superação de obstáculos para possibilitar a presença das mesmas à Escola.

Profissionais da educação afirmaram, ainda, que a pobreza que atingia a maioria das famílias atendidas também contribuía para dificultar a relação Escola e família no campo, tendo em vista que os pais não teriam condições financeiras para possuírem veículo próprio ou para mantê-los. Sobre tais condições de vida das famílias, uma das profissionais afirmou: 
“... Tem uт... uma boa parte deles [pais] não vem porque não tem transporte, às vezes depende do patrão, tem que pegar uma carona. Eles mudam pra zona rural então tudo é bem mais complicado, né? Então quando o patrão vem que leva eles pra fazer compra, eles já aproveitam e já passa aqui e já fala 'Opa, eu tenho que passar na Escola', né? Já vê o filho de cima, já vê o número um, já vê o número dois, o quatro e o cinco, já resolve tudo num dia só...". (Profissional Vilma)

Notamos que Vilma indicou que, considerando a distância geográfica entre Escola e famílias e a falta de transporte dos pais para irem à instituição escolar, famílias tinham de contar com "favores" prestados pelo patrão - "caronas" - para poderem ir à Escola (em ocasiões que iam para cidade comprar mantimentos). Tal fala aponta para a existência de um entrelaçamento entre as condições de vida/de trabalho no campo e a Escola, e para a existência de uma dependência das famílias de outras pessoas e circunstâncias para irem à instituição escolar.

Poliana mencionou ainda que a questão da distância geográfica entre Escola e pais somada a outras características das famílias atendidas, além das condições de vida e de trabalho das mesmas, interferiam na relação Escola e família:

“... Pela comodidade da van pegar na porta e deixar na porta, eles se acomodam (...) Pega o aluno na porta de casa, traz pra Escola, eles sabem que que a partir do momento que entrou dentro daquela van o filho não vai desviar o caminho, vai chegar na Escola (...) E sabe que na hora que sair da Escola vai chegar em casa, então eles acomodam (...) Por isso a gente tem, não vem tanto na Escola...". (Profissional Poliana)

Poliana mencionou que as famílias do campo - isentas da responsabilidade de levar e buscar suas crianças na Escola - se "acomodavam" e que, por isso, não frequentavam a instituição escolar. Nessa fala, evidenciamos que a entrevistada defendeu a ideia de que as famílias do campo, por vezes, não se mobilizavam para comparecer à Escola.

Uma das profissionais relatou que a manifestação de falta de interesse e de mobilização de pais para irem à Escola em momentos como as reuniões, superando a distância geográfica existente, seria influenciada pelo formato não atrativo de atividades realizadas pela Escola para encontro com as famílias, conforme já discutido no item anterior, "... a Escola, fica uma coisa desgastada...". A concepção de que famílias do campo teriam pouco interesse no que tange à vida escolar de seus filhos e que, também por este motivo, não iam à Escola também foi defendida por outras entrevistadas que afirmaram:

“... São os mesmos pais [que vêm às reuniões], que tipo assim, é... 'Não, eu preciso acompanhar a vida do meu filho' (...) Agora têm outros que fala assim 'Não é... pode fazer o que vocês achar aí que tá bom!'. Né? Tem pais que (...) 'Não. Eu vou na Escola quando der'...” (Profissional Vilma). 
“... Às vezes a gente faz uma reunião eles [pais] perguntam assim 'Vai liberar o transporte, pra ir na reunião?'. Então a Prefeitura não libera o transporte pros pais (...) Não libera. Então o que acontece? Os pais não vêm na reunião, mas assim se você chama pra uma Festa Junina... Aparece um pouquinho mais do que a da reunião (...) Aí eles dão um jeitinho de vir (...) [Os pais não vêm à Escola devido] a falta de interesse (...) É a falta de interesse, porque aquele pai mais preocupado com a vida escolar do filho, aquele pai que incentiva, que quer que o filho vença, que vai atrás, que ajuda, aquele pai ele vem na reunião... Agora tem uns que não têm assim, não, não sei o que acontece mas não aparece... Não liga, não manda um bilhete, não quer saber como que o filho está na Escola (...) É, descaso, é desinteresse (...) É porque na Festa Junina veio bem mais pais do que na reunião...". (Profissional Patrícia)

“... Eu acho dificil [a relação existente entre a Escola e famílias], porque a gente tá muito, é, distante da família, né?, e mas nós não julga que só por causa do transporte que eles não têm não, hoje a família tá muito desinteressada da função social da Escola, de procurar a Escola, de saber como que o filho tá na Escola, eles tão delegando para a Escola, 'Se vira lá', então acho que não é culpa tanto do transporte, acho mais é as famílias que, o interesse pela educação assim, eles não sabem, aqui a gente atende aqui, a clientela que a gente atende, eu sei que os alunos lá do Otávio [Escola da cidade], daquelas Escolas lá centrais lá, a função social da Escola pra eles é totalmente diferente dessa aqui, né? (...) Essa aqui eles não... Não acha que a Escola vai contribuir assim, não tem, não dá tanta importância, não é a primeira importância, pros filhos deles, não é às vezes a Escola, né? (...) Eles preocupam com comer, fica preocupado com o que ter o que comer, né?, ter o que comer (...) Essas coisas assim...”. (Profissional Dirce)

Entrevistadas defenderam a ideia de que as famílias do campo não compareciam à Escola somente em função da distância física entre as instituições e da ausência do transporte escolar, mas também por atribuírem unicamente à instituição escolar o papel de educar as crianças e por não valorizarem o futuro educacional de seus filhos. Dirce ressaltou ainda que a função social da Escola para as famílias de camadas altas (atendidas por Escolas centrais na cidade) seria diferenciada da função social para as famílias pobres do campo, tendo em vista que estas, ao contrário de populações urbanas e de camadas altas, não atribuem valor à Educação, estando mais voltadas para o atendimento de suas necessidades básicas, como de alimentação.

Nesse cenário, profissionais defenderam a concepção de que famílias do campo/de camadas populares não valorizavam a Educação de seus filhos e que, por isso, não iam à Escola. Cabe ressaltarmos que, em outros relatos, discutidos anteriormente, profissionais indicaram que características do campo (distância geográfica entre Escola e famílias), características do município (política de transporte), características da Escola (formato das atividades de encontro com as famílias) e condições de vida e de trabalho das famílias (falta de veículo próprio, isolamento das residências) seriam elementos que atravessavam a relação Escola e família e contribuíam para a distância entre estas instituições. No entanto, as profissionais, em outros momentos, como evidenciado nos relatos acima, pareceram desconsiderar tais características para discutir a relação Escola e família, atribuindo às 
famílias a responsabilidade por distanciamentos entre as instituições escolar e familiar. Nas falas citadas, entrevistadas pareceram defender a ideia de que se as famílias do campo valorizassem a Escola e a vida escolar de seus filhos, obstáculos para irem à instituição escolar - como a distância geográfica - poderiam e deveriam ser superados pelas mesmas, “... a gente tem pouco contato com os pais, né? (...) É, o contato é pouco, mas que eu não acho que é só porque não tem o transporte não. Eu acho porque ele não tem interesse muito interesse de vir, porque se ele quisesse vir ele arrumava um jeito, vinha, né? (...) Igual, a mesma coisa se você precisa muito ir no médico você dá um jeito e vai! Agora se você tem muita preocupação com a educação do seu filho, com a Escola do seu filho você dá um jeito e vai!..." (Profissional Dirce).

Sobre as famílias do campo e a manifestação de desinteresse pela Educação, defendida por entrevistadas, uma das profissionais afirmou ainda:

“... Família é a base, acho que a educação a família não tá dando, delegou tudo pra Escola, né? (...) $\hat{E}$, valores, né? Valores tinha que vir já, pelo menos, mais ou menos moldado alguns valores, né?, de conduta, um monte de coisa, e não tá vindo, e hoje não tem isso, mais na criação não... Então a familia é fundamental, a família bem estruturada né?, não é família desestruturada que ainda traz. pra cá e fica pior ainda. E ainda traz pra cá e fica pior ainda, mas uma família bem estruturada, não estou falando daquele nucleozinho de pai, de mãe, de tio, estou falando uma família que não tem essas brigas que têm, não passa necessidades que passam, né? Que, eu acho que a criança, é, a gente vê a diferença de uma criança que tem um... Um acompanhamento familiar e das outras que não têm, é gritante (...) gritante, muito, muito, muito. Então, a nossa aqui a maioria não tem acompanhamento dos, da família, porque, a família, pra eles a função social da Escola é segundo plano, não sei se é a segunda, terceira ou quarta, não é a primeira, e que a maioria também aqui são famílias totalmente, né?, desestruturadas, não é uma é, quase todos filhos de vó, né?, ou... é a vó que cria, então é complicado...". (Profissional Dirce)

Dirce vai compondo, em sua fala, um quadro de significações sobre família, pobreza e rural. Notamos que a profissional, baseando-se no discurso das famílias pobres como sendo “desestruturadas", afirmou que os pais do campo não dariam valor à Educação de seus filhos e que, por isso, não acompanhariam a vida escolar das crianças, contribuindo para a distância na relação Escola e família. Para a entrevistada a "desestrutura" das famílias do campo estaria relacionada com o fato de as mesmas, na visão da profissional, vivenciarem conflitos e carências e, ainda, pelo fato de a criança não ser cuidada pelos pais.

A partir das discussões realizadas anteriormente, percebemos que a distância geográfica entre Escola e família foi indicada por profissionais como um importante elemento que atravessava a relação entre as instituições e que contribuía para dificultá-la. A distância 
física no campo foi mencionada ainda como sendo um elemento que trazia especificidades para a relação Escola e famílias no âmbito rural, diferenciando-a da relação Escola e famílias no âmbito urbano.

Notamos, ainda, que as profissionais, em alguns momentos, recorreram à questão da distância geográfica, associada à falta do transporte e ao formato das atividades realizadas na Escola junto às famílias, para explicar a não ida da maioria dos pais ao contexto escolar. No entanto, em outros momentos, as profissionais pareceram se aproximar da concepção de que a ausência dos pais na Escola se daria devido à distância geográfica associada ao fato de as famílias nem sempre estarem interessadas em comparecer à instituição escolar.

Como forma de sistematizar tais dados, apresentamos o quadro a seguir:

\begin{tabular}{c|c}
\hline Elementos que se associam à distância geográfica e influenciam a ida da família à Escola \\
\hline Características do município & $\begin{array}{c}\text { Não disponibilidade do transporte escolar para as } \\
\text { famílias }\end{array}$ \\
\hline Características das famílias & Falta de transporte das famílias, devido às \\
& condições de pobreza \\
\cline { 2 - 2 } & Desinteresse das famílias pela Escola \\
\hline Características da Escola & Formato das atividades (Desgastantes) \\
\hline
\end{tabular}

Quadro 26 - Elementos que se associam à distância geográfica e influenciam a ida da família à Escola - Relatos das profissionais

\subsubsection{Significações das famílias sobre a relação Escola e famílias e as distâncias geográficas no campo}

Famílias do campo destacaram, ao longo das entrevistas, que a distância geográfica entre a Escola e suas residências era um complicador na ida das mesmas à instituição. A distância física associada à não disponibilização do transporte escolar para os pais, segundo entrevistadas, dificultavam a relação Escola e família, conforme indicam os relatos a seguir:

“... Eles não liberam transporte pros pais irem. Então dá muito pouco pai nessas reuniões (...) Aí se eles liberassem eu creio que daria mais pais nas reuniões, mas eles não libera. Aí vai muito pouco pais...". (Genitora Irene)

“... Mesmo se eles [profissionais da Escola] falam assim 'Ah, vem e tal' né? Agora se eles liberassem o transporte, eu creio que tinha mais gente que ia lá mais, sabe? (...) Mas aí não libera, então. Já não libera nas reuniões fixa. Eu acho que eles tinham que liberar, né? No dia de reunião tinha. Já não libera nos dia da reunião, então não tem nem como eles ir outro dia também. Ir lá pra conversar, conhecer professor, porque tem muitos que não conhece. Não sabe nem que jeito é o professor dos 
filhos. Então eu conheço porque já foram... muitos lá já foram meus professores. Então por isso que eu conheço...". (Genitora Irene)

“... Que nem assim que eu falei pra elas [profissionais da Escola], eu gostaria de estar participando mais da Escola, só que a Escola tinha que abrir, tinha que ver, tinha que abrir esse espaço pros pais tá podendo ir na van pelo menos uma vez por mês, de quinze em quinze dias pra estar indo pra saber como está seu filho. A minha vontade de ir é grande, só que eu não tenho... a minha possibilidade de ir é muito difícil! (...) Uma vez [a Escola] chamou [para reunião] mesmo, mas aí não fui... Ir que jeito? Pra ir até que dava pra ir eu ia no ônibus, mas ia voltar de que jeito? (...) Esperar achar uma carona de lá pra cá?, muito difícil...". (Genitora Inês)

As famílias indicaram que o fato de não haver transporte escolar para os pais associado à distância geográfica contribuíam para o distanciamento entre as instituições familiar e escolar. Segundo Irene, a ausência do transporte escolar prejudicava a participação dos pais na Escola, fazendo com que muitas famílias não conhecessem os professores das crianças e atividades realizadas na e pela instituição escolar junto aos seus filhos. Irene pontuou ainda que, diante da ausência do transporte escolar, o fato de a Escola estar "aberta à família”, por vezes, não garantia/permitia a participação dos pais na mesma. Percebemos que as famílias indicaram o desejo de que a relação Escola e pais fosse mais próxima.

Famílias entrevistadas indicaram ainda que, tendo em vista distância geográfica, o fato de as mesmas não terem veículo próprio, devido às precárias condições de vida, também contribuía para não comparecerem em atividades na Escola:

“... Teve uma festinha aqui no São João e eu não pude ir por causa que não teve, não tinha carro pra nós irmos. Porque o carro aqui que entra aqui é só van que vem pegar eles. Ela não leva, não dá carona pra ninguém (...) E se nós quiser ir, não tem como nós ir, só se for a pé... A pé, ichi!, é longe...". (Genitora Flaviana)

Segundo entrevistadas, muitas famílias não possuíam veículo próprio, o que impossibilitava/dificultava a ida das mesmas à Escola. De acordo com Irene, havia também famílias que possuíam carro próprio, porém alguns de seus membros deixavam de ir à Escola, tendo em vista que não tinham conhecimentos sobre a direção de veículos automotores, “... Porque não é todo mundo que tem carro que pode ir. Às vezes tem, mas não sabe dirigir, então não adianta nem ter..." (Genitora Irene). Houve ainda o relato de genitoras que afirmaram depender da presença dos maridos para poderem ir à instituição escolar, tendo em vista que os mesmos utilizavam os veículos para trabalhar e/ou estudar. Na ausência dos maridos, as genitoras afirmaram a impossibilidade de irem à Escola, “... pra mim ir [à reunião] eu teria que ir de carro e ele [marido] tinha que ir pra Escola [Faculdade] e não teve 
como eu ir...” (Genitora Irene), “... não deu pra mim ir [evento na Escola] porque ele [marido] estava viajando e quando ele está aqui, dá pra mim ir, porque daí a gente vai..." (Genitora Adriana).

É importante mencionar que, partindo do desejo de obter mais informações sobre a criança e o cotidiano escolar, famílias indicaram o uso de diferentes estratégias para comparecem na instituição escolar, superando, dessa forma, algumas das dificuldades que as afastavam da Escola, como a distância geográfica e a falta de transporte. Dentre tais estratégias estão: o uso de "caronas", a ida a pé e a utilização de mototáxi e do transporte escolar das crianças, conforme consta nos relatos a seguir:

“... Aquele dia [reunião] eu fui no carro mais ela e o marido dela [gerente da fazenda onde moram] (...) Aqui só tem um carro, o dia que nós tem que ir em algum lugar, tem que ir com ele...". (Genitora Flaviana)

“... O dia que eu fui fazer a matrícula eu fui a pé mais uma colega minha (...) Nós saímos daqui o quê?, umas onze horas da manhã e viemos chegar aqui era quase sete horas da noite (...) Até chegar lá nós demoramos, a pé (...) Acho que de a pé acho que dá mais, deve ser umas três hora (...) O dia da matrícula, saí daqui era umas onze hora da manhã mais ela. Quando chegamos aqui já dava quase sete horas que ela caminha muito [devagar]... e eu precisava vir andando e ficando em pé na sombra pra esperar ela (...) Ela é... caminhava devagar, tem que esperar, os pés doíam aí eu ficava em pé na sombra esperando ela...”. (Genitora Flaviana)

“... Teve uma vez, no Dia das Mães, eu fui de mototáxi, como eu fui nessa reunião, eu fui de mototáxi e voltei na van (...) Perguntei pra Vilma se eu, eu não usei o transporte sem perguntar pra Vilma, porque o transporte não é liberado pros pais, igual você deve saber lá. Eu perguntei pra ela, ela falou, 'Conversa com o motorista, se o motorista te trouxer, você pode vir... '...”. (Genitora Fabíola)

Nos trechos acima, notamos que Flaviana afirmou que uma das formas que utilizou para comparecer à Escola foi por meio da carona de seu "patrão". Tal fala indica como aspectos da vida e do trabalho no campo - como a distância entre as residências e a Escola/ a falta de transporte próprio devido às precárias condições de vida/ a dependência do patrão para se deslocarem - atravessavam e configuravam possibilidades de relação entre a Escola e famílias. Flaviana mencionou ainda que, diante da falta de veículo para ir à Escola, tinha ido à mesma a pé, o que pareceu ser algo que demandou um longo tempo e que foi desgastante fisicamente.

Já Fabíola afirmou que fora à Escola de mototáxi e pelo transporte escolar disponibilizado para as crianças. Sobre o uso do transporte escolar, a entrevistada indicou que, apesar de não ser autorizado pelo município, cabia ao motorista a decisão de permitir ou não a utilização do mesmo pelas famílias, mediante solicitação destas, o que apontou para a existência de um poder do motorista junto aos pais, sendo possível ao mesmo deliberar se as 
famílias poderiam ou não utilizar o veículo para ir à Escola. Ao contrário do que ocorreu com Fabíola, a genitora de Artur afirmou que, em um dia de festa na Escola, houve a recusa do motorista de levá-la até a instituição. Diante de tal fato, a entrevistada buscou outra forma de comparecer à Escola, conforme indica o relato a seguir:

“... Teve uma vez que teve uma Festa das Crianças (...) Minha menina falou, 'Nossa mãe, a tia falou que assim, a mãe que quiser ir pode ir no ônibus', só que ela também não sabia que a mãe não poderia andar no ônibus, né? (...) Aí a gente levantou cedo e tal, na maior animação porque o ônibus ia passar era 7 horas ali. A gente levantou eu acho que era 5 e meia, tomou café, arrumou e tal e eles na maior animação pra eu ir, queria que eu fosse e tal... Aí na hora que chegou ali que eu falei que o motorista falou que eu não ia, né?, que eu desci do ônibus aí ele foi, eu me senti tão mal, né?, deles irem sozinhos e eu não fui, porque eles estavam tão animados por eu ir... Aí eu corri aqui, abri a chave da porta, peguei a chave da moto, porque eu estava prontinha, e fui lá no rapaz [caseiro] que tira leite e falei que era pra ele me levar lá (...) Aí eu fui, eu cheguei lá, peguei eles de surpresa ainda, né? Porque eles, de surpresa ainda (...) Ixi, eles acharam bom até, porque eles acharam que eu não ia, né? 'Mãe mas você veio, você veio de quê?'. Aí eu falei assim: 'Não o rapaz me trouxe aqui, o Lindomar', que é o rapaz, né? 'Me trouxe'. Aí eles, nossa acharam bom demais. Aí a gente foi no pulapula, nos trem, comeu pipoca...". (Genitora Adriana)

Evidenciamos, a partir da apresentação do episódio acima, o desejo da genitora e dos filhos de que Adriana fosse e participasse de atividades na instituição escolar. Notamos ainda o empenho de Adriana, diante da ausência do transporte escolar, para conseguir ir a um evento promovido pela e na Escola. Para tanto, a mesma recorreu a outra forma de ir à instituição escolar: em uma moto do marido e dirigida pelo caseiro, que teve que se ausentar do serviço nesse período.

No entanto, entrevistadas pontuaram que o uso de meios de locomoção "alternativos" nem sempre era possível, tornando as idas à Escola dificultadas e, por vezes, inviáveis. A disponibilização do transporte escolar emergiu como uma demanda das famílias do campo, tanto para comparecerem às reuniões escolares como em outros momentos para obter informações sobre o cotidiano da criança e para participar de atividades da Escola.

A partir das discussões realizadas acima, percebemos que a distância geográfica foi indicada pelas famílias como sendo um importante elemento que influenciava a ida à Escola. Tendo em vista a grande distância física entre as instituições escolar e familiar, genitoras afirmaram que a falta de transporte escolar; a ausência de transporte das famílias (devido às suas condições econômicas); e, no caso de famílias que possuíam veículo, a não possibilidade de utilização deste pelas genitoras, contribuíam para dificultar o comparecimento das mesmas à Escola. Apesar de tais obstáculos, genitoras afirmaram utilizar, quando possível, formas 
alternativas para comparecerem na instituição. Tais idas, segundo famílias, às vezes eram viáveis em momentos que não eram necessariamente os organizados pela Escola, como as reuniões. O desejo e interesse das famílias em estar presente na Escola e acompanhar a vida escolar de seus filhos emergiram como algo que mobilizava as famílias para irem à Escola e, ainda, que fazia com que a disponibilização do transporte escolar pelo Poder Público despontasse como uma reivindicação das mesmas.

Como forma de sistematizar as discussões realizadas neste item, apresentamos o quadro a seguir:

\section{Elementos que se associam à distância geográfica e influenciam a ida da família à Escola}

Características do município

Características das famílias
Não disponibilidade do transporte escolar para as famílias

Falta de transporte das famílias, devido às condições de pobreza

Utilização de veículo da família para trabalho e estudo do genitor Interesse das famílias pela Escola

Quadro 27 - Elementos que se associam à distância geográfica e influenciam a ida da família à Escola - Relatos das famílias

\subsubsection{Aproximações e distanciamentos das significações das profissionais e famílias sobre a relação Escola e famílias e as distâncias geográficas no campo}

A partir das discussões realizadas nos itens anteriores, notamos que profissionais e famílias entrevistadas destacaram a distância geográfica existente entre Escola e as residências das famílias como elemento que atravessava a relação entre as instituições e que dificultava a ida dos pais à Escola. No entanto, percebemos que as significações de profissionais e famílias sobre os elementos que influenciavam o comparecimento da família à Escola (somando-se à distância geográfica entre as instituições), ora se aproximaram e ora se distanciaram, conforme podemos observar no quadro a seguir: 


\begin{tabular}{c|c|c}
\hline $\begin{array}{c}\text { Elementos que se associam à } \\
\text { distância geográfica e } \\
\text { influenciam a ida da familia à } \\
\text { Escola }\end{array}$ & Profissionais & Famílias \\
\hline Características do município & $\begin{array}{c}\text { Não disponibilidade pelo } \\
\text { município do transporte escolar } \\
\text { para as famílias }\end{array}$ & $\begin{array}{c}\text { Não disponibilidade pelo } \\
\text { município do transporte escolar } \\
\text { para as famílias }\end{array}$ \\
\hline Características das famílias & $\begin{array}{c}\text { Falta de transporte das famílias, } \\
\text { devido às condições de pobreza }\end{array}$ & $\begin{array}{c}\text { Falta de transporte das famílias, } \\
\text { devido às condições de pobreza }\end{array}$ \\
\cline { 2 - 3 } & ----------- & $\begin{array}{c}\text { Utilização de veículo da família } \\
\text { para trabalho e estudo do genitor }\end{array}$ \\
\cline { 2 - 3 } & Interesse das famílias pela Escola \\
\cline { 2 - 3 } & Desinteresse das famílias pela \\
Escola & ------------ \\
\hline Características da Escola & $\begin{array}{c}\text { Formato das atividades voltadas } \\
\text { para os pais (Desgastantes) }\end{array}$ & -------------- \\
\hline
\end{tabular}

Quadro 28 - Elementos que se associam à distância geográfica e influenciam a ida da família à Escola - Relatos das profissionais e famílias

Tanto profissionais como famílias mencionaram que, diante da distância física, a não disponibilidade do transporte escolar pelo município e a falta de condições financeiras das famílias rurais para adquirirem veículo próprio e que lhes dessem autonomia de locomoção, contribuíam para distanciamentos entre pais e profissionais.

Profissionais afirmaram ainda que o modo como eram organizados, na Escola, os encontros com os pais, vistos como sendo desestimulantes, também contribuía para o não comparecimento de famílias à instituição. Já as famílias não mencionaram que o formato de atividades realizadas na Escola seria um elemento que contribuiria para sua ausência no âmbito escolar. Conforme será discutido no próximo subcapítulo, percebemos que em certas circunstâncias há avaliações por famílias de que alguns encontros com profissionais seriam difíceis para os pais, porém, de acordo com os relatos, famílias não destacaram que tal fato colaboraria para não irem à Escola, tendo em vista o desejo de acompanharem seus filhos.

Os dados indicaram, ainda, que as profissionais, apesar de, em alguns momentos, recorrerem às características da Escola e do município para justificarem a ausência de famílias no âmbito escolar, em outros momentos, defenderam a ideia de que pais não iriam à instituição por um desinteresse em relação à Educação e à trajetória escolar de seus filhos. No entanto, ao contrário do que foi defendido em alguns momentos por profissionais, famílias indicaram, em suas falas, a existência de vontade e interesse em irem à Escola para obter informações sobre o cotidiano de seus filhos na instituição. A distância geográfica e a falta de transporte, segundo as famílias, seriam os principais elementos que contribuíam para ausência dos pais na Escola. 
Genitoras mencionaram ainda que o fato de algumas famílias terem carro próprio também não significava a possibilidade de o utilizarem para comparecer ao âmbito escolar, já que os mesmos eram usados para trabalho e estudos dos genitores, elemento este não conhecido pelas profissionais.

A partir das discussões acima, percebemos que as significações das profissionais e famílias sobre os elementos que se associavam à distância geográfica e atravessavam a relação Escola e famílias se aproximaram e se distanciaram, conforme representado na figura a seguir:

\section{Significações aproximaram-se}

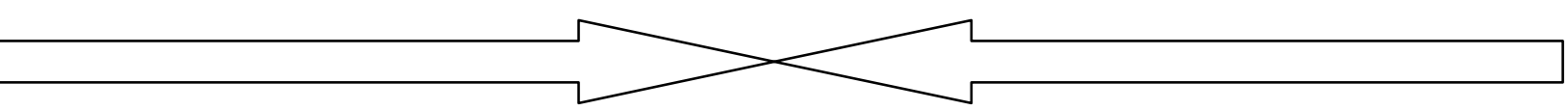

- A aproximação das significações das profisssionais em relação às significações das famílias ocorreu em momentos nos quais características do município (não disponibilização de transporte escolar para pais da zona rural) e das famílias (condições econômicas, pobreza) foram referenciadas como elementos que atravessavam a relação Escola e família e influenciavam a ida dos pais à Escola. Tais significações foram construídas entrelaçadas à concretude da realidade investigada e indicam um conhecimento da Escola sobre aspectos das condições de existência das famílias atendidas.

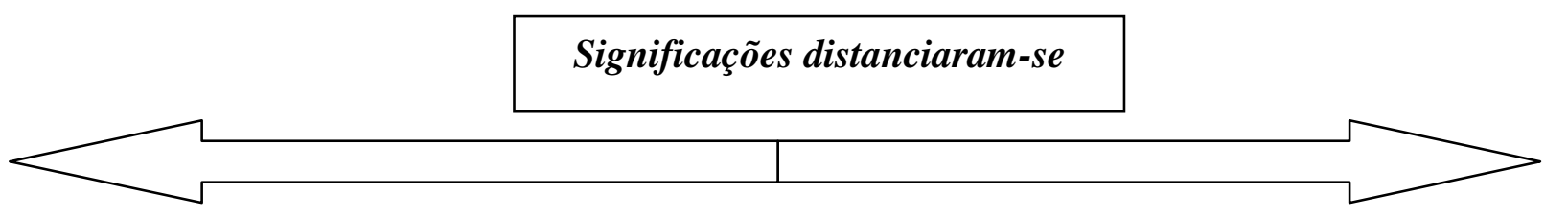

- O distanciamento das significações das profissionais em relação às significações das famílias pareceu ocorrer em momentos que:

- Profissionais se aliaram aos discursos (gerais) construídos socialmente sobre famílias populares e rurais como sendo desinteressadas pela Escola e Educação dos filhos, presentes na matriz sócio-histórica;

- Profissionais recorreram ao formato das reuniões para justificar a ausência das famílias na Escola; enquanto as genitoras indicaram outros elementos relativos às suas condições de vida e trabalho, não referenciados pela Escola, para explicar o não comparecimento dos pais ao âmbito escolar. 


\subsection{SITUAÇÕES PROBLEMÁTICAS NA RELAÇÃO ENTRE A ESCOLA FLAMBOYANT E AS FAMÍLIAS DO CAMPO}

A análise dos dados indicou que a relação entre a Escola e as famílias do campo era atravessada por situações que denominamos de problemáticas. Segundo dicionários da língua portuguesa, "problemática" significa a totalidade dos problemas relativos a um assunto, a uma situação. O "problema" pode significar: 1. Qualquer assunto ou questão que envolve dúvida, incerteza ou dificuldade; 2. Situação difícil; 3. Algo a ser resolvido (DICIONÁRIO ON LINE, MICHAELIS, WIKTIONARY, 2012).

No presente trabalho, entendemos que situações problemáticas na relação Escola e família seriam situações difíceis e com possibilidade de serem significadas e resolvidas de diferentes formas pelos atores envolvidos. A seguir apresentamos os dados construídos sobre esta temática por profissionais e famílias do campo.

\subsubsection{Significações das profisssionais sobre situações problemáticas na relação entre a Escola e as famílias do campo}

A análise das entrevistas das profissionais de educação indicou a existência de situações problemáticas na relação entre a Escola Flamboyant e famílias do campo. Tais problemáticas se relacionavam à entrada da criança na Escola; à baixa frequência da criança na instituição escolar; a queixas sobre aprendizagem e comportamento da criança na Escola e a acidentes envolvendo a criança no âmbito escolar. Nos tópicos a seguir, propomos discutir as significações construídas pelas profissionais sobre tais situações problemáticas.

\subsubsection{O ingresso da crianca na Escola}

Uma das profissionais de educação indicou que o ingresso e a adaptação de crianças provenientes de assentamentos e acampamentos rurais à Escola constituíram-se como uma situação problemática, difícil para esta instituição. Paula afirmou que houve períodos em que a Escola atendia somente famílias que trabalhavam em fazendas e nas indústrias da região, mas que, posteriormente, com a chegada de famílias vinculadas a um movimento social de luta pela terra a Escola passou a atender também a famílias que viviam em acampamentos e assentamentos rurais. Para a entrevistada, o atendimento de famílias acampadas/assentadas e suas crianças causou impactos na instituição escolar, na relação Escola e família: 
“... E essas pessoas quando chegaram aqui inicialmente, as pessoas desse tipo de movimento eles acham que tudo funciona na base da força e do poder sabe?, então essas crianças vieram aqui pra Escola sem limite, até que elas acostumaram com as normas da Escola, né?, se adapta e tudo, a gente teve muito problema de adaptação porque eles acham que as coisas é conseguida assim com intimidação, com força, com poder e não é assim, tudo tem suas regras e tem que ser respeitado porque senão o sistema não funciona (...) A gente teve um problema de adaptação em relação a esses sem-terra, que passaram a vir pra cá. Depois com o tempo eles adaptaram, né?, às normas da Escola, e melhorou um pouco no caso a parte no caso do relacionamento, da disciplina deles com a gente, com os próprios alunos da Escola que já moravam aqui, mas no início foi bem complicado...". (Profissional Paula)

De acordo com Paula, o atendimento das famílias acampadas/assentadas do movimento social trouxe problemas para a Escola, tendo em vista que, para a entrevistada, as pessoas que participam do movimento de luta pela terra manifestavam comportamentos de desrespeito às normas estabelecidas pela Escola. Notamos que a profissional de educação apresentou uma visão negativa das famílias ligadas ao movimento social e indicou o quanto a relação da Escola com as mesmas era dificultada devido às características das famílias e suas crianças. Tal tensão na relação com as famílias acampadas/assentadas parece ter sido "atenuada", de acordo com a profissional, devido à adequação da família à Escola. A ideia de que as famílias tenham que se "adaptar" às normas preestabelecidas pela Escola confronta com princípios que acenam para a participação da comunidade escolar, como os pais, as crianças e os profissionais, inclusive na construção de regras escolares.

Apesar de mencionar uma melhoria na relação da Escola com as famílias do campo assentadas/acampadas, Paula pareceu indicar ainda a permanência de uma tensão entre a instituição escolar e as mesmas, “... no início foi bem complicado (...) Hoje já está mais pacífico o movimento né?, já tem vários assentamentos aqui, né?, já estão mais estabilizados, já com um certo tempo já morando aqui, então já adaptaram à Escola e tá funcionando assim até certo ponto assim, bem razoavelmente...".

\subsubsection{A baixa frequência e queixas sobre a aprendizagem da criança na Escola}

Uma das profissionais de educação mencionou que houve situações nas quais solicitou a ida de famílias à Escola para solucionar problemáticas relacionadas à baixa frequência e aprendizagem da criança na instituição escolar. No relato a seguir, Patrícia falou sobre um dos casos de solicitação aos pais - que moravam dentro de uma indústria na qual não era permitida a entrada do transporte escolar - para comparecerem à Escola: 
“... Nós tivemos caso de um aluno [do Ensino Fundamental] aqui que ele faltava muito (...) Ele não aprende, não aprende mesmo (...) Falta muito. Você quer ver ele vir na Escola é dia de educação Física. Educação Física ele tá aqui na Escola. Então ele falta muito nas aulas. Eu liguei na casa, muito custo, mandei vários bilhetes também, não voltou... Liguei um dia a irmã que atendeu, o telefone nunca atendia, no dia que atendeu é a irmã 'Minha mãe não tá', fui, deixei recado. Tentei falar de novo, não conseguia... Aí consegui falar com o pai. Aí ele olhou pra mim, olhou não, ele falou pra mim assim no telefone: 'Não, mas meu filho não gosta de ir pra Escola'. Falei: 'Não tem que gostar, tem que vir, tem que vir pra Escola'...”. (Profissional Patrícia)

Notamos que Patrícia se colocou na defesa da Educação e sua importância para a criança. A profissional afirmou que buscou entrar em contato com a família da criança que apresentava prejuízos no processo de aprendizagem devido às ausências na Escola e indicou dificuldades para conseguir ter acesso a esta família. Para tanto, a entrevistada mencionou o uso de diversos instrumentos de comunicação, como bilhete e telefone, demonstrando uma mobilização da Escola para se relacionar com a família. Notamos que, no momento de encontro da profissional com o pai da criança - via telefone -, houve o estabelecimento de um diálogo no qual a Escola questionou o motivo alegado pela família para justificar a ausência da criança na Escola. Nessa situação, notamos como na relação Escola e famílias pode haver diferentes visões e posicionamentos de pais e profissionais diante de acontecimentos envolvendo a criança, o que constitui um desafio para tal relação, para o compartilhamento da educação da criança entre as instituições familiar e escolar.

Patrícia relatou que, nesse caso, houve ainda outros momentos em que ocorreu a solicitação, pela Escola, de que os pais comparecessem à mesma para conversar sobre a criança. A entrevistada indicou que, diante das dificuldades de entrar em contato com a família, a Escola solicitou auxílio a uma assistente social da Prefeitura, que na época assessorava a instituição escolar, conforme consta no relato abaixo:

“... Nesse caso ela [assistente social da Prefeitura] chegou a conseguir [que os que pais fossem à Escola]. Lembra de eu te falar que ela conseguiu entrar em contato com a assistente social da granja? (...) A assistente social da granja entrou em contato com os pais, fez com que os pais viessem aqui, aí foi um caso de serviço, né?, porque eles preocuparam com o serviço deles (...) Eles não vieram aqui, porque... eles vieram aqui por causa de preocupação com o serviço (...) Por quê? Porque foi a assistente social do serviço deles que mandou eles virem aqui...". (Profissional Patrícia)

Patrícia mencionou que a assistente social da Prefeitura contatou a assistente social da Indústria - onde a família residia e trabalhava - para mediar a relação da Escola com os pais e garantir a presença dos mesmos no âmbito escolar. Tal ação indicou uma junção dos âmbitos escolar e laboral na resolução de problemáticas relativas à Escola, bem como dos poderes destas instituições em relação à família, para garantir o comparecimento dos pais. A utilização 
de recursos de autoridade e de profissionais "externos", objetivando mediar a relação Escola e pais, pode apontar para uma carência/ineficiência de instrumentos de diálogos e para fragilidades na relação entre as instituições escolar e familiar. Patrícia afirmou que o comparecimento da família à instituição escolar ocorreu devido ao receio dos pais em relação ao trabalho. Notamos que a submissão da família ao mundo do trabalho vinculou-se/foi utilizada para que ocorresse a submissão da família à Escola.

De acordo com a entrevistada, apesar do uso de diversos instrumentos na relação com a família, houve uma demora no comparecimento desta na instituição escolar, “... Isso foi quase o ano inteiro pra gente conseguir isso (...) Que os pais viessem aqui...”, o que provavelmente não contribuiu para solucionar a problemática da não frequência e da aprendizagem da criança na Escola, tendo em vista a proximidade com o término do ano letivo.

Ao longo da entrevista, Patrícia mencionou ainda que solicitou o comparecimento à Escola de outra família cuja criança apresentava queixas relativas à aprendizagem no âmbito escolar:

“... Ah... nós tínhamos, nós temos uma aluna aqui que a professora me reclamou muito que ela é muito assim avoada, sabe? Assim então a professora falou 'Ela não conversa, ela não dá trabalho nenhum, mas eu fico preocupada porque pra ela fazer as coisas tem que 'Fulana faz, copia'...' (...) Então o que acontece? Isso aí é um caso preocupante porque a gente tentou falar com a mãe várias vezes (...) mandei vários bilhetes pra ela... Um dia ela falou que vinha... no feriado (...) Ela marcou a data pra vir no feriado (...) Eu mandei um bilhete de volta, 'Fala pra sua mãe, que na segunda e na terça é recesso e feriado, mas ela marcou assim às vezes nem prestou atenção, né?, ela marcou o dia de vir bem no feriado...' (...) Ai por fim sabe qual foi a resposta que chegou aqui pra mim? 'Minha folga é só no sábado. Não tem como eu ir... '. Quer dizer, eu tentei de todas as maneiras, de todos os meios que eu podia falar com essa mãe, eu não consegui...". (Profissional Patrícia)

Percebemos que a entrevistada indicou novamente a mobilização da Escola para conversar com uma das famílias atendidas pela instituição e cuja criança apresentava queixas escolares relativas à aprendizagem. Patrícia mencionou que houve o estabelecimento de diálogos com a família por meio de bilhetes, nos quais buscava negociar um dia para a mesma comparecer à instituição escolar. No entanto, segundo Patrícia, a ida da família à Escola não ocorreu e foi justificada pela família devido à impossibilidade de se ausentar do trabalho. Esta situação nos indica a existência de diferenças entre o período de descanso do trabalho das famílias rurais e o período de atendimento da instituição escolar e de trabalho das profissionais. Tal fato constitui um desafio na relação Escola e família e aponta para a necessidade de haver arranjos diversos na rotina de trabalho do professor e de funcionamento da Escola para ampliar as possibilidades de encontro com as famílias atendidas. 
A profissional de educação, ao narrar o desfecho do caso, apontou para a impotência/dificuldade da Escola em encontrar com famílias atendidas, mesmo após recorrer a diversos instrumentos, “... eu tentei de todas as maneiras, de todos os meios que eu podia falar com essa mãe, eu não consegui...".

O uso de diferentes estratégias para comunicar com a família e o insucesso na ida dos pais à Escola foram indicados pela profissional em outro caso, “... Teve uma outra também que eu tentei várias vezes (...) Ela mudou. Pra você ter uma noção tem mais de dez dias que ela mudou, não vem mais na Escola e eu não falei com a mãe...” (Profissional Patrícia). Nessa situação, evidenciamos como a questão da migração, vivida pelas populações do campo, também se destacou como um elemento que atravessava a relação entre a Escola e famílias rurais.

\subsubsection{As queixas sobre comportamento da criança na Escola}

De acordo com profissionais da educação, situações que envolviam problemas de comportamento da criança resultavam na solicitação do comparecimento da família à instituição escolar. Uma das profissionais relatou um dos casos vivenciados na Escola:

“... Eu já tive outro caso que o... foi o Tiago, eu não sei o que aconteceu no caminho entre a sala de aula e a van, um dia... você não estava não, o dia que o rapaz trouxe uns livros pra vender, veio na segunda e entregou uns folhetinhos eles levaram pra casa. Aí na terça-feira alguns trouxeram dinheiro pra comprar os livros (...) Outros não. Aí eu tomo muito cuidado com isso pra não entregar livro pra criança errada, não comprar um diferente do que o pai anotou, porque eles vão mesmo reclamar, e a mãe mandou dinheiro pra comprar dois e no caminho a menina [Lilian] desviou um e chegou só com um em casa. Aí no outro dia a mãe veio, né?, e eu não tiro a razão dela não, se fosse eu eu ia também. 'Cadê o outro livro? Eu mandei dinheiro pra dois'. Vamos fazer a pesquisa na sala, estava com um aluno, ele chegou em casa com o livro, 'A tia que me deu, meus colegas da sala tudo comprou e, a, como eu não tinha, a tia ficou com dó e me deu' e não foi isso que aconteceu, né? Aí o pai veio no outro dia, ele assim, eu acredito que ele não deve ter dado o castigo que ele prometeu não, mas falou de uma forma muito rude com a criança e disse que ia tirar todos os brinquedos, ia pôr tudo em uma caixa em cima do guarda-roupa, ia tirar a televisão e ele não ia ter Natal esse ano, como se, porque pra eles o Natal é a melhor coisa que tem. Como se fosse fácil tirar da cabecinha da criança que aquele dia é dia de Natal, esquece que não tem Natal esse ano e esquece que o Natal existe, mas ele falou de uma maneira tão grosseira com a criança que eu achei que foi muito ao extremo também, que não tinha necessidade daquilo tudo. Só que a gente, eu principalmente não falei nada pro pai naquela hora porque é uma coisa que se eu tivesse que falar alguma coisa eu ia chamar o pai e falar longe da criança, eu não posso tirar também a autoridade do pai na frente do aluno. Porque depois nem a professora nem os pais dão conta dele...". (Profissional Poliana)

Poliana afirmou que tendo em vista características da Escola Flamboyant, cuja dinâmica não garantia supervisão da criança durante todo o tempo, ocorreram problemas na 
compra de livros na Escola, apesar dos cuidados realizados pela profissional para evitá-los. Tais problemas na compra dos livros envolveram a ida de duas famílias à instituição escolar. A ida da família de Lilian à Escola indicou uma ação da mesma pela busca de garantia, na relação com a Escola, de seus direitos, na medida em que havia realizado o pagamento de um dos livros que tinha desparecido. A profissional indicou compreender e concordar com a ação da mãe na situação. O comparecimento do genitor de Tiago na Escola apontou para a adoção pelo mesmo, frente à ação do filho de levar o livro da colega para casa, de ações educativas que, na visão de Poliana, foram excessivamente rígidas. Ao falar da postura do pai de Tiago frente à criança, a profissional demonstrou uma sensibilidade frente à criança e indicou seus limites na relação com a família no que se refere ao processo de educação da criança.

Na situação narrada por Poliana, evidenciamos dificuldades advindas do processo de compartilhamento do cuidado e educação da criança entre Escola e família. Outro caso citado por esta profissional também evidenciou tensões existentes nesta relação:

“... Eu escutei do pai do Iago que ele é daquela forma, culpada é a Escola (...) Eu já não acho. Lógico que a Escola tem a sua parcela de culpa no comportamento do aluno, tem sim, mas a culpa não é só da Escola. Se ele não tem limite nenhum na Escola é porque os pais não dão limite também em casa...". (Profissional Poliana)

Poliana afirmou que havia famílias que, em situações envolvendo problemas de comportamento do filho na Escola, atribuíam a responsabilidade pelas ações da criança à instituição escolar. Percebemos que esta profissional aliou-se à concepção de que há uma contribuição conjunta da Escola e família no desenvolvimento da criança - no caso, de seu comportamento - o que apontava para a necessidade de uma atuação também conjunta dessas instituições para resolução da problemática. Poliana indicou que dificuldades de compartilhamento de responsabilidades nessas circunstâncias, como no caso de Iago, ocorriam também em outras instituições: “... É assim, não só aqui, todas as Escolas que eu passei têm pais que jogam a responsabilidade toda na Escola...".

Sobre o caso de Iago, outra profissional afirmou:

“... O Iago começou assim, chegou na Escola começou a dar muito trabalho, a mãe não aceitava, né?, muitas das vezes ela achava que a Escola não tinha interesse pelo filho, que a gente, pouco caso praticamente, o que não é verdade porque a gente dá atenção pra todas as crianças iguais (...) Só que assim ó, ele esquece muito as coisas, né? Ele tá muito agressivo, você presenciou, você viu ele agredir os colegas, bater... então não é aquilo que a mãe falou, então ele chegou num ponto de agredir a professora, né? Então a gente teve que chamar a mãe porque? Pra ver o que que tá acontecendo com ele, pra ver o que que tá acontecendo em casa até mesmo pra ela ajudar, 
conversar com ele, pra ele melhorar, pra ele melhorar o comportamento aqui na Escola...”. (Profissional Patrícia)

Patrícia apontou que Iago, desde seu ingresso na instituição escolar no início do ano letivo, estava apresentando comportamentos vistos como sendo problemáticos pela Escola. No relato notamos que se por um lado a família buscava encontrar explicações para o comportamento da criança na Escola, por outro lado a Escola parecia buscar justificativas para o comportamento da criança na família. Para a profissional, caberia à família modificar suas práticas domésticas para que a criança se comportasse de forma diferenciada na instituição escolar.

Patrícia construiu significações semelhantes sobre os problemas comportamentais de crianças na Escola em outro caso, citado a seguir:

“... A gente teve um caso de um aluno que ele começou dando muito trabalho aí eu fui assim, investigar, não bem, né?, investigar, eu fui procurar saber o porquê desse aluno dar trabalho, tanto trabalho assim, quer dizer, a história dele é... complicada (...) Eu chamei a mãe, quando eu escutei a história de vida dessa criança eu percebi o porquê do comportamento dele (...) Então quando a criança às vezes, maioria das vezes, é... não tem interesse, pai não ajuda, pai não incentiva, chega na Escola ele conversa, dá trabalho, não sei o que, você manda bilhete, aquilo ali pra ele... Atrapalha muito no rendimento, muito, muito mesmo...". (Profissional Patrícia)

Patrícia, na situação mencionada, se aliou também neste caso à concepção de que a origem dos problemas da criança estaria no âmbito familiar. Tais significações sobre as famílias envolvidas em casos problemáticos na Escola encontram apoio em significações, discutidas em subcapítulo anterior, sobre famílias "desestruturadas" e que não valorizariam a educação escolar do filho, “... Valores tinha que vir já, pelo menos, mais ou menos moldado alguns valores, né?, de conduta, um monte de coisa, e não tá vindo, e hoje não tem isso, mais na criação não... Então a família é fundamental, a família bem estruturada né?, não é família desestruturada que ainda traz pra cá e fica pior ainda..." (Profissional Dirce).

Partindo da ideia de que "a causa" de problemas das crianças na Escola estaria nas famílias, Patrícia mencionou que as tentativas de intervenção junto às crianças (conversa, prática de castigo) não logravam sucesso, “... Que não adianta... às vezes a gente chama, conversa, às vezes deixa de castigo não é bem castigo, né? A gente não usa mais essa palavra hoje em dia, deixa pensando, mas às vezes a criança... não melhora...”. Ao discutir as dificuldades para resolver problemáticas envolvendo as crianças, Patrícia vislumbrou a necessidade de mediadores na relação Escola e família, sendo os mesmos profissionais de outras áreas de saber: 
“... Seria bom [ter assistente social na Escola] até pra resolver muitos casinhos pendentes, muitas coisinhas, tem os casos assim, mais agravantes, né? (...) É o caso que eu te falei, por exemplo, o menino dando trabalho que eu fui descobrir o problema dele é na família (...) Quer dizer uma assistente social pra entrar em intervenção nisso aí, dar um apoio, dar um suporte, encaminhar pra um psicólogo (...) Ajudar aquela criança (...) No caso desse outro aluno aí, ele não aprende, ele falta muito, ele não vem à Escola, uma assistente social pra fazer o quê? Pra procurar os pais, pra ver porque que esse menino não vai à Escola, porque que esse menino não tá aprendendo (...) Encaminhar ele pra algum lugar (...) Nós tivemos casos aqui também de outro aluno porque os pais é um descaso total com o aluno, então o menino dá muito trabalho, muito. O que a gente pode fazer pra ajudar aqui na Escola a gente faz, mas ele continua dando trabalho... Até que ultimamente ele melhorou muito, melhorou muito (...) Então o que que acontece?, mas o pai é muito descaso é... seria o caso de um acompanhamento. Esse seria o caso de um acompanhamento mesmo (...) Ajudaria muito. Se tem uma assistente social, qualquer coisa você encaminha pra um Conselho Tutelar, porque chega um ponto que você tem que encaminhar pra um Conselho Tutelar...". (Profissional Patrícia)

Patrícia ressaltou novamente o insucesso da Escola na melhoria de tais casos, a partir da realização de ações junto à criança, bem como a precariedade de recursos na relação com as famílias para resolver as problemáticas. A profissional afirmou a necessidade de auxílio de profissionais e órgãos externos em situações difíceis ocorridas no âmbito escolar, o que indica fragilidades na relação Escola e família e aponta para limites no papel da Escola nessas circunstâncias.

\subsubsection{Acidentes envolvendo a crianca na Escola}

Casos de acidentes envolvendo a criança na Escola foram relatados por profissionais, que os indicaram como sendo situações difíceis para os envolvidos, conforme podemos observar na fala a seguir:

“... A Tatiana lá do segundo período, né?, aconteceu um episódio com ela aqui, foi até lá no parquinho que ela caiu de ponta assim no toquinho, aí ela machucou a vulva, né? Aí a mãe ficou, porque não sabia o que tinha acontecido, não sei o que. Aí eu falei pra ela... aí ela veio, e eu falei, 'Não. Eu vou te acompanhar, nós vamos'. Ai eu fui, fui para o Posto Médico, aí chegou no Posto Médico o médico veio e falou assim. 'Ah, isso aqui...', aí perguntou pra mãe: 'Você confia na Escola em que sua filha estuda?', ela falou assim, 'Confio, tem até a vice-diretora aqui... por que?', 'Ah, porque a gente tá achando que pode ser outra coisa, tal'. Falei 'Não, então vamos verificar o que pode ser, porque eu acho assim, que o interesse da gente, né?, não é camuflar nada, né? Se aconteceu...'. Ai cheguei lá na medicina, aí a moça falou assim, 'Você acha que na Escola você pode ter algum funcionário que pode, tal...?'. Eu falei assim: 'Olha antigamente a gente mandava o filho da gente pra Escola e pra igreja você falava assim 'Tá indo com Deus, né?, tá bem guardado'. Hoje em dia a gente não pode confiar, hoje qualquer um que der em cima do seu filho você tem receio, né? Tanto é que eu vim com a mãe, o outro médico falou pra gente procurar mais, eu vim, né?'. Agora a menina o tempo todo ela só falava o que tinha acontecido, né? Aí tal e fez, um tanto de exame lá e tudo, aí comprovou que realmente (...) ela tinha caído, e engraçado assim que ela não roxeou nada por fora, ficou normal, só a genitália dela que saiu um pouquinho de sangue, aí a mãe já pensa, eu não tiro a razão da mãe não porque você fica preocupada, né? Você não sabe onde que tava. Então assim, igual eu tô te falando o espaço aqui, né?, pra você vê não tem um parquinho assim adequado 
pra eles, né?, porque aquele pequeno lá mas não tem a adequação total né?, tinha que ser uma areia direitinho pra eles estarem brincando, né? (Profissional Vivian)

Notamos que a profissional indicou que, no caso citado, em que uma das crianças da Educação Infantil se feriu na instituição escolar, a Escola e a família da criança se uniram para resolver a problemática, o que se constituiu como uma ação de compartilhamento do cuidado da criança entre as instituições escolar e familiar. Nessa situação específica, percebemos que a profissional aprovou e se aliou ao comportamento da genitora de buscar compreender o ocorrido com a criança. Vivian indicou que a família desconhecia o cotidiano da criança na instituição e que a Escola não tinha informações precisas sobre o evento envolvendo Tatiana. No relato de Vivian evidenciamos ainda que a entrevistada usou o caso de Tatiana para justificar as inadequações físicas da Escola para atender crianças da Educação Infantil.

Sobre o acidente envolvendo a Tatiana, Poliana também relatou:

“... Aqui eu achei tudo muito assim, é... depois que toca aquele sinal lá some todo mundo e os meninos ficam a Deus dará e depois acontece alguma coisa ninguém quer assumir a responsabilidade (...) Chegou [a acontecer], no meu segundo dia de trabalho (...) Deu a hora do intervalo pra eles lancharem, tocou o sino, eu desci e depois eu não voltei pra sala porque era uma quarta-feira. A menina machucou no parque as partes íntimas, caiu sentada em cima do toco, não contou pra professora que foi pra sala, foi reclamar só pra mãe em casa. A mãe veio achando que... (...) Chegou a sangrar (...) Aí eu não tiro razão nenhuma, a mãe estava achando que a menina tinha sido violentada na Escola (...) E foi na hora do recreio, hora que eles estão soltos. É, e eu vi também outras crianças que não são alunos meus na hora do intervalo quebrou braço, lixou o braço. Se tivesse uma pessoa, não é, assim, mais só pra eles verem que tem uma pessoa por perto eles já correm menos, já empurram menos um ao outro, então isso evita de machucar, né? (...) A mãe veio na Escola no outro dia, a Vivian foi com ela na Medicina fez perícia médica, tudo e constatou que realmente foi queda em algum material (...) Depois disso a mãe veio pra conhecer a professora, me explicou o que tinha acontecido, né?, mas assim foi tudo tranquilo, mas até que ver que foi um acidente mesmo... Se fosse com minha filha eu tinha ficado apavorada, igualzinho a mãe dela ficou, né? (...) Mas a menina hora nenhuma falou que alguém tinha mexido com ela, ela sempre falou que tinha caído em cima do toco, mas os pais não acreditaram...". (Profissional Poliana)

Poliana, assim como Vivian, defendeu a ação da família de buscar conversar com a Escola sobre o ocorrido com a filha. Ao falar sobre o caso, Poliana teceu críticas à forma como eram organizadas as atividades na Escola junto às crianças - sem supervisão de adultos e que colocava as crianças em risco na instituição e contribuía para a ocorrência de acidentes como o de Tatiana. Poliana mencionou ainda o quanto tal situação gerou inquietações para a família e para a Escola, mas que foram atenuadas a partir da ação conjunta entre as instituições escolar e familiar. 
A partir da análise e discussão das significações das profissionais relacionadas às situações problemáticas, discutidas anteriormente, apreendemos que profissionais indicaram em suas falas elementos que estariam envolvidos com a ocorrência de tais situações, bem como elementos que dificultariam a resolução das mesmas. Tais dados são apresentados nos quadros a seguir:

\begin{tabular}{|c|c|c|}
\hline Situações problemáticas & \multicolumn{2}{|c|}{$\begin{array}{c}\text { Elementos envolvidos na ocorrência das situações } \\
\text { problemáticas }\end{array}$} \\
\hline Ingresso da criança na Escola & $\begin{array}{l}\text { Características das } \\
\text { crianças/das famílias }\end{array}$ & $\begin{array}{l}\text { Comportamento da criança de } \\
\text { indisciplina, influenciado pelo } \\
\text { pertencimento ao movimento social }\end{array}$ \\
\hline $\begin{array}{l}\text { Queixas sobre frequência e } \\
\text { aprendizagem da criança }\end{array}$ & Características das famílias & $\begin{array}{l}\text { Práticas familiares de educação da } \\
\text { criança }\end{array}$ \\
\hline \multirow{5}{*}{$\begin{array}{l}\text { Queixas sobre o comportamento } \\
\text { da criança na Escola }\end{array}$} & \multirow{3}{*}{$\begin{array}{l}\text { Características das } \\
\text { crianças/das famílias }\end{array}$} & Ambiente familiar "desestruturado" \\
\hline & & $\begin{array}{c}\text { Práticas familiares de educação da } \\
\text { criança }\end{array}$ \\
\hline & & $\begin{array}{l}\text { Dificuldades da criança na relação } \\
\text { com colegas e professora e na } \\
\text { realização de atividades escolares }\end{array}$ \\
\hline & \multirow[t]{2}{*}{ Características da Escola } & $\begin{array}{c}\text { Práticas escolares de educação da } \\
\text { criança }\end{array}$ \\
\hline & & $\begin{array}{c}\text { Dinâmica que permitia crianças } \\
\text { ficarem sem supervisão de adultos em } \\
\text { horários, como no recreio }\end{array}$ \\
\hline \multirow[t]{2}{*}{$\begin{array}{l}\text { Acidentes envolvendo a criança no } \\
\text { âmbito escolar }\end{array}$} & \multirow[t]{2}{*}{ Características da Escola } & $\begin{array}{l}\text { Dinâmica que permitia crianças } \\
\text { ficarem sem supervisão de adultos em } \\
\text { horários, como no recreio }\end{array}$ \\
\hline & & $\begin{array}{l}\text { Inadequação do espaço físico da } \\
\text { Escola para crianças da EI }\end{array}$ \\
\hline
\end{tabular}

Quadro 29 - Elementos envolvidos na ocorrência das situações problemáticas - Relatos das profissionais 


\begin{tabular}{|c|c|c|}
\hline Situações problemáticas & \multicolumn{2}{|c|}{$\begin{array}{c}\text { Elementos que dificultavam a resolução das situações } \\
\text { problemáticas }\end{array}$} \\
\hline Ingresso da criança na Escola & $\begin{array}{l}\text { Características das } \\
\text { crianças/das famílias }\end{array}$ & $\begin{array}{l}\text { Possuíam dificuldades de se } \\
\text { adaptarem às regras da Escola }\end{array}$ \\
\hline \multirow[t]{3}{*}{$\begin{array}{l}\text { Queixas sobre frequência e } \\
\text { aprendizagem da criança }\end{array}$} & \multirow[t]{2}{*}{ Características das famílias } & $\begin{array}{l}\text { Residiam em locais isolados (dentro } \\
\text { de indústrias), o que dificultava o } \\
\text { encontro e a conversa da Escola com } \\
\text { as famílias }\end{array}$ \\
\hline & & $\begin{array}{l}\text { Tempos de descanso no trabalho das } \\
\text { famílias diferente do período de } \\
\text { atendimento da Escola, o que } \\
\text { dificultava a ida das famílias à } \\
\text { instituição escolar }\end{array}$ \\
\hline & Características do campo & $\begin{array}{l}\text { Distância geográfica que dificultava } \\
\text { o encontro e a conversa da Escola } \\
\text { com as famílias }\end{array}$ \\
\hline \multirow{4}{*}{$\begin{array}{l}\text { Queixas sobre o comportamento } \\
\text { da criança na Escola }\end{array}$} & \multirow[t]{3}{*}{ Características das famílias } & Ambiente familiar "desestruturado" \\
\hline & & $\begin{array}{l}\text { Concepção das famílias de que a } \\
\text { educação da criança caberia somente } \\
\text { à EI }\end{array}$ \\
\hline & & $\begin{array}{l}\text { Concepção da família de que a } \\
\text { Escola era desinteressada pela } \\
\text { criança }\end{array}$ \\
\hline & $\begin{array}{l}\text { Características do campo e do } \\
\text { município }\end{array}$ & $\begin{array}{l}\text { Grande distância geográfica e falta } \\
\text { de transporte escolar para os pais, o } \\
\text { que dificultava o encontro e a } \\
\text { conversa da Escola com as famílias }\end{array}$ \\
\hline $\begin{array}{l}\text { Acidentes envolvendo a criança no } \\
\text { âmbito escolar }\end{array}$ & Características da Escola & $\begin{array}{c}\text { Dinâmica que permite crianças } \\
\text { ficarem sem supervisão de adultos } \\
\text { em horários, como no recreio, e que } \\
\text { resultava na falta de informação da } \\
\text { Escola sobre acontecimentos } \\
\text { envolvendo a criança em tais } \\
\text { horários }\end{array}$ \\
\hline
\end{tabular}

Quadro 30 - Elementos que dificultavam a resolução das situações problemáticas - Relatos das profissionais

Nos quadros acima, notamos que as profissionais indicaram que diferentes elementos, tais como características das crianças e das famílias, da Escola, do campo e do município atravessavam a relação Escola e famílias e influenciavam a ocorrência e resolução de situações problemáticas nesta relação. As características das crianças e das famílias presentes nas situações problemáticas estariam relacionadas às formas de a criança se comportar na Escola; às práticas familiares de educação da criança; às concepções dos pais sobre as práticas de cuidado e educação da criança na Escola; às formas de organização familiar e às condições de vida e de trabalho das famílias nos territórios rurais. As características da Escola consistiam em suas práticas escolares de educação da criança; em suas dinâmicas e organização das atividades junto às crianças na instituição; e na estrutura física da Escola. 
Características do campo e do município, como a grande distância geográfica entre Escola e família e ausência de transporte escolar para os pais, também foram mencionadas como importantes elementos que dificultavam a resolução, por famílias e profissionais, de problemáticas envolvendo a criança na instituição escolar.

\subsubsection{Significações das famílias sobre situações problemáticas na relação entre a Escola e as famílias do campo}

A análise das entrevistas das famílias indicou a existência de situações problemáticas na relação entre a Escola e famílias do campo. Tais situações problemáticas se relacionavam à entrada da criança da Escola; a queixas sobre o comportamento da criança na Escola; a acidentes envolvendo a criança no âmbito escolar e ao adoecimento da criança. Nos tópicos a seguir, discutimos as significações construídas pelas famílias sobre estas situações problemáticas.

\subsubsection{O ingresso da crianca na Escola}

Famílias do campo mencionaram que os primeiros encontros com os profissionais da Escola ocorreram nos primeiros dias de entrada da criança na instituição escolar, nos quais houve o acompanhamento dos filhos por seus respectivos pais, por iniciativa dos mesmos, conforme já discutido anteriormente. Segundo a genitora de Fabrício, a ida da família à Escola nos primeiros dias de ingresso da criança na instituição ocorreu devido ao desejo da família, “... Não [foi a Escola que convidou para ir]. Foi eu que quis... Não, [a Escola] não pede, não pede [para ir], mas também não opõe (...) Se a gente quiser ir, visitar a Escola, a Escola está aberta... Igual o dia da reunião... A diretora mesmo falou, né?, que se quiser ir pode ir..." (Genitora Fabíola).

Sobre esse momento, entrevistadas relataram:

“... Eu fiquei muito feliz [com a ida de Iago para a Escola] assim, foi uma emoção muito grande, ainda mais que ele estava muito satisfeito, sabe? $\mathrm{E}$ eu tinha muito medo, por ele ser uma criança muito difícil de trabalhar com ele, de lidar com ele, que ele é muito custoso, então eu estava com muito medo tanto é que fui no primeiro dia de aula pra isso, pra conversar com a Pamela, com a diretora, com todo mundo que é pra 'Olha estou entregando meu filho pra vocês, mas meu filho é assim, assim... Pelo amor de Deus fica de olho nele!' porque o Iago se você soltar ele, ele sai doido desembestado, e ali, você viu que ali é tudo aberto? Então, meu medo maior era esse ali. Dele sair igual um doido desvairado e parar naquela rodovia, que ali está pertinho da rodovia...". (Genitora Inês) 
“... Nossa, nos dois primeiros dias eu fui junto, igual eu te falei, fui aliviada porque eu estava junto e não estava perdendo ele pro mundo. Mas no terceiro dia que eu deixei ele, eu chorei o dia inteiro. Hora que eu vi ele entrando na van, Moisés morria de rir de mim, olhava pra trás e ria de mim... Aquilo pra mim foi, mesmo que eu perdesse ele assim, sabe?, ficar o dia inteiro pra lá... Nossa, a casa ficou grande, vazia, sem aquele menino que eu nunca tinha deixado com ninguém, foi, foi difícil, não foi fácil não...". (Genitora Fabíla)

Notamos que as genitoras afirmaram que, na ida da criança para a Escola, experienciaram diferentes sentimentos. Inês relatou ter sentido alegria pelo fato de Iago estar feliz em ir para a instituição escolar e medo do filho se ferir na Escola. Já Fabíola indicou ter sentido alívio por estar acompanhando o filho nos primeiros dias e angústia em ver Fabrício ir no transporte escolar, sem sua companhia.

Percebemos como a situação de compartilhar o cuidado e educação da criança com a instituição escolar foi inicialmente uma experiência difícil para as genitoras. Além de sentimentos oriundos da ausência da criança na família, no período de sua permanência na Escola, notamos que características do campo - como a distância geográfica que implicava no transporte das crianças - bem como características estruturais da Escola, vista por famílias como sendo inadequadas e inseguras para crianças da Educação Infantil, contribuíam para tornar tal complementaridade ainda preocupante para as genitoras.

A forma como o trabalho é organizado em algumas famílias do campo - em suas residências ou não - também parece se destacar como importante elemento que influencia a forma como os familiares vivenciam o compartilhamento do cuidado e educação da criança com a Escola. Na fala de Fabíola, notamos como a ida da criança para a Educação Infantil se constituiu como um momento de impacto e mudanças para a família. Para Fabíola, que afirmou ficar o dia todo trabalhando na fazenda onde residia, a ida de Fabrício para a instituição escolar pareceu ter gerado grandes mudanças em seu cotidiano. No relato de Irene, cujos três filhos haviam ido para a Escola Flamboyant aos 5 anos, percebemos como o fato de a genitora estar trabalhando em ambiente público na época que seus primeiros filhos foram para a Escola e de estar trabalhando em sua residência na ocasião que Íris ingressou na Educação Infantil interferiu na forma como lidou com esse momento:

“... Só com o meu menino mais velho que eu não fui [nos primeiros dias à Escola], porque aí eu trabalhava e não foi liberado pra mim ir com ele (...) Eu trabalhava e eu não sentia tanta falta, sabe? Por que era assim: Eu trabalhava, chegava cinco horas, né? Então ele chegava seis horas. Era uma hora só que a gente não estava junto, né? Mas era acostumado ficar longe dele no período que eu estava trabalhando (...) Não senti muito não... Mas era ruim, né? Saber que o seu filho não estava dentro de casa... tal, era ruim (...) Agora a Íris...! A Íris era muito grudada comigo. É até hoje. Então, onde eu estou, ela está atrás. Ela está dentro de casa... ela brinca, brinca, mas está sempre junto 
comigo (...) Senti muita falta dela. Senti dos três, mas dela por ela estar mais junto comigo, então foi mais... Por ser mais nova também eu creio...". (Genitora Irene)

Notamos como a ida da criança para a Escola foi também um momento de adaptação para as famílias rurais, adaptação esta influenciada pela questão do trabalho no campo. Em outros relatos percebemos ainda como a forma de a Escola lidar com esse momento na instituição influenciou as vivências das crianças e famílias nesse período:

“... Já a outra, a segunda, eu fui com ela (...) Eu estava de folga (...). Fui no primeiro dia. Aí fui, gente que horror! O que tinha de menino chorando na Escola! Por causa das mães. Ela não chorou. 'Isa eu tô aqui, vou ficar te esperando ali de fora. Na hora do recreio, na hora que você sair a mamãe tá ali'. Não chorou no primeiro dia. Foi... aí no segundo dia o professor falou 'Oh, é bom vocês não vir e tal...', né? Aí, tudo bem, aí no segundo dia eu não fui. Quando foi o terceiro dia eu levei ela pra ela pegar a van e ela saiu lá de casa de boa, né? Cheguei na portaria [de onde residem] ela chorando. 'Minha filha por que você tá chorando?', 'Ah, porque eu não queria ir pra Escola, por isso e isso e tal...', né? Fiquei com o coração na mão, né? Mas falei assim: 'Mas minha filha você tem que ir pra Escola'. 'Liga lá na Escola e fala pro Isaías ficar'. Liguei, né? Aí a diretora falou 'Olha, eu não posso deixar o Isaías aqui por causa dela, porque um dia ela vai ter que vir sozinha'. Falei: 'Tá bom'. Aí expliquei pra ela. Falou 'Mãe, hoje eu não vou na Escola', chorando. Falei 'Tudo bem, então vamos embora pra casa'. Cheguei, expliquei pra ela, falei 'Olha é assim, você tem que ir pra Escola, porque precisa, você tem que aprender, agora os seus coleguinha está tudo lá dentro de sala, é ruim você ficar sem a mamãe? É! A mamãe também acha ruim. Você acha que a mamãe vai ficar feliz aqui sem você? Não... Igual seus irmãos também não vão ficar felizes. Mas hora que você chegar a mamãe tá lá pra te buscar, não precisa de você chorar' (...) Aí uns três dias... Aí no outro dia ela já foi. Você via assim que o olho dela estava cheio de lágrima (...) Foi caladinha três dias seguidos. Ai, aquilo era horrível pra mim. Deus que me livre. Mas ela foi. Aí acostumou...". (Genitora Irene)

$\mathrm{Na}$ fala de Irene, percebemos que o professor da instituição escolar pareceu defender a concepção de que a adaptação da criança à Escola dependeria da criança, sendo que a presença de familiares poderia dificultar tal processo. Na Escola, não havia um programa de acolhimento da criança ingressante e da família na instituição escolar. No relato de Irene, foi indicado que a ida da criança para a instituição escolar sem a presença de familiares, conforme sugerido pela Escola, não foi tranquila para a filha. A genitora afirmou que buscou realizar ações junto à Isa para auxiliá-la no processo de adaptação à Escola. Irene indicou que coube à criança e à família se submeterem/“acostumarem” com tal situação, à custa de certo sofrimento.

No que se refere à Íris e seu irmão mais velho, a genitora relatou que houve também o acompanhamento das crianças pela família no período de ingresso na Escola. No entanto, a genitora ressaltou que a adaptação destes filhos à instituição escolar foi tranquila e facilitada pelo fato de os mesmos terem outras crianças da família na instituição. 
Segundo Fabíola, o fato de a criança (não) ter irmãos na Escola influenciava ainda a decisão dos pais irem ou não à instituição escolar nos primeiros dias de ingresso da criança, conforme consta no relato a seguir:

“... No segundo dia de aula que foi, foi só eu e mais duas mães. Eu não lembro quem que foi, uma é a mãe da Tatiana, que eu estou te falando, que ficou lá, as outras mães não foram não, deixou as crianças irem sozinhas (...) Muitas porque já tinha mais filho que estudava na Escola, né?, que ali tem muitos meninos da sala do Fabrício que se você conversar tem mais criança que estuda em outra sala já, lá na Escola Flamboyant...". (Genitora Fabíola)

Fabíola indicou que a adaptação da nova criança à Escola seria mediada e facilitada por outras crianças da família que já frequentavam a Escola. Tendo em vista que Fabrício não possuía irmãos, Fabíola afirmou como sendo importante sua ida à instituição escolar nos dois primeiros dias. No entanto, ao contrário de Irene - ao falar sobre a ida da irmã de Íris para a Escola -, Fabíola apontou que a professora do filho foi aberta à presença das famílias no âmbito escolar:

“... No primeiro dia eu fiquei até ajudei a professora a montar os negocim, a arrumar a sala, ficou eu e uma outra mãe ajudando. Aí já no segundo dia já não fiquei, fiquei sentada só por perto ouvindo o que estava acontecendo, vendo se ele estava enturmado... Aí no terceiro dia já foi sozinho (...) Foi, foi tranquilo. A professora é muito boa, recebeu as mães que foi, né?, com os filhos. Foi bem recebida...". (Genitora Fabíola)

Fabíola avaliou positivamente a receptividade da Escola em relação às famílias nos primeiros dias de ingresso da criança na instituição escolar e indicou, em outras falas, como sendo tranquila a adaptação de Fabrício à instituição. Porém, a genitora apontou como a ida da criança para a Escola ainda se constituía, após decorrer quase todo o ano, como um momento difícil para a família.

“... Agora hoje eu já estou mais acostumada... Fico ansiosa esperando por ele, mas eu já estou mais acostumada (...) Mas quando dá a hora dele chegar, você já fica esperando já. Eu olho pra lá pra ver se largaram a Maria, porque eu vejo largar a Maria, você lembra dela, né?, pegou lá. Daqui eu vejo largar, pra ver se está largando pra chegar meu Fabricim (...) Estou, o tempo inteiro você está pensando nele lá, até dá vontade de ligar lá pra saber, mas você fica amolando a Escola, né?, é melhor deixar, esquecer e ir acostumando mesmo...". (Genitora Fabíola)

Fabíola afirmou que, em certa medida, havia se acostumado com a ida de Fabrício para a Escola. Notamos, porém, que preocupações iniciais da família no momento de entrada da criança na instituição ainda permaneceram, como as relacionadas com o uso do transporte escolar pelo filho. Em falas de Inês e de Adriana, notamos que as inquietações em relação à 
segurança da criança na Escola, tendo em vista suas características estruturais, também se mantiveram. Aspectos que estariam presentes no momento de entrada da criança na Escola e que seriam difíceis para a família como as relacionadas com a falta da criança no âmbito familiar parecem ser atenuados. No entanto, aspectos relacionados com as características do campo - como a distância geográfica que implicava no transporte das crianças nos territórios rurais - e características estruturais da Escola permaneceram como sendo alvo de preocupação para as famílias. Fabíola, no relato citado acima, indicou como era difícil para a família estabelecer limites, não ser invasiva na relação com a Escola, diante da ansiedade e desejo de saber como sua criança estava na instituição escolar.

\subsubsection{As queixas sobre o comportamento da criança na Escola}

Famílias mencionaram que ocorreram situações problemáticas envolvendo o filho na Escola, sendo estas relacionadas à existência de queixas sobre o comportamento da criança no âmbito escolar. Tais situações foram narradas pelas famílias de Artur e de Iago e serão apresentadas, a seguir, nos seguintes itens: 5.5.2.2.1. As queixas sobre o comportamento de Artur na Escola e 5.5.2.2.2. As queixas sobre o comportamento de Iago na Escola.

\subsection{As queixas sobre o comportamento de Artur na Escola}

Adriana afirmou, conforme já discutido anteriormente, que os encontros com a Escola ocorreram em diversos momentos. Ao falar de tais encontros, notamos que a família se colocou na posição de preocupada com a criança e foi indicando o quanto se mobilizou para solucionar problemáticas ligadas ao comportamento do filho na Escola, por meio do estabelecimento de diálogos com os profissionais de educação. Adriana indicou a importância de haver proximidades na relação entre a Escola e as famílias, tendo em vista a educação da criança e defendeu a ideia de que as instituições escolar e familiar se complementavam, “... Eles falam assim que a Escola e os pais têm que ser juntos, né? Então assim (...) a Escola ajuda também a gente, né? Com tudo, né? Questão de educação, com tudo...”. (Genitora Adriana)

Adriana, em um de seus relatos, indicou como ocorria a relação com a Escola nos momentos de encontro com a família: 
“... Uma vez eu fui lá na cidade, aí nós estávamos passando mais cedo, era umas quatro horas, cinco horas, aí eu falei assim: 'Adriano, vamos passar lá na Escola e vamos pegar os meninos de surpresa'. Aí eu fui lá, aí ela [profissional da Escola] falou tal que ele estava jogando pedra nos meninos tal, aí ela pôs ele lá no... Tem um sofá lá que elas põem também os meninos ficar de castigo, só que ele estava mais era deitado (...) Aí quando eu cheguei, ele estava lá no sofá. Aí ela falou que ele estava jogando pedra nos meninos, aí a tia pôs ele lá. Aí eu conversei com ela lá e tal. Aí ela falou que era pra eu tirar o que ele mais gostava (...) Gostei de conversar com ela, porque ela fala assim um... de um jeito assim que não te deixa chateada, sabe? Ela vai falando, falando, mas assim você sabe que é pro seu bem, né? No dia que eu fui assim conversar com a Pamela, eu fiquei assim muito... Achei ela muito grossa assim, fiquei muito chateada, porque ela falou assim de um jeito muito esquisito, que eu tinha que... 'Senão quando esse menino tiver grande você não vai dá conta!'. Sabe? De um jeito assim...". (Genitora Adriana)

Adriana afirmou que, em situações problemáticas envolvendo a criança no âmbito escolar, a Escola recorria às práticas de castigos para punir comportamentos de Artur. A genitora apontou ainda que, nessas situações problemáticas, houve o estabelecimento de diferentes relações entre a família e a Escola, avaliadas de forma diferenciada pela genitora. Adriana indicou que houve situações em que a relação com a Escola teria sido interessante, apoiadora para a família, mas que teriam ocorrido episódios em que a relação com a Escola teria sido de autoridade em relação à genitora. Em ambas as circunstâncias, segundo as falas de Adriana, houve a busca pela Escola de orientar, auxiliar a família no que tange às suas práticas de educação junto à criança.

Em outros relatos notamos que a Escola, para modificar o comportamento de Artur, sugeria à família a adotar algumas práticas de educação no âmbito privado:

“... A tia [Profissional Pamela] falou, né?, que era pra mim levar ele no psicólogo e tal, né? Aí eu tenho conversado com ele, explico pra ele... eu converso com ele, né? Aí a menina, a psicóloga falou assim que a gente não precisa bater, conversa. Só que às vezes a gente conversa parece que não resolve (...) E aí... eu explico pra ele... (...) Aí eu falei que eu não queria mais bater nele não, mas se ele continuar assim de novo, eu ia bater nele de novo. Aí essa semana ela chega e eu pergunto todo dia: 'Alice o Artur foi lá pro mato?', ai ela: 'Não', mas a Pamela, um dia ela me chamou lá e explicou, né?, que realmente a situação estava bem difícil que ele estava muito teimoso, estava batendo nos meninos, que não obedecia ela, que era pra mim ver o que que eu poderia fazer...". (Genitora Adriana)

“... Como minha menina estuda ali, então às vezes quando elas precisam falar algum recado, então elas mandam pela menina (...) Aí fala: 'Alice fala pra sua mãe pegar esse Artur e dar uns conselhos nele, dar umas varadas nele, conversar com ele que ele tá muito teimoso, muito desobediente... '...". (Genitora Adriana)

Adriana mencionou que a professora Pamela sugeriu à família dialogar com a criança, aplicar castigos físicos em Artur e encaminhar a criança para serviços de Psicologia. Evidenciamos como a Escola buscava intervir nas práticas domésticas de educação da criança, 
ora incentivando o uso de procedimentos mais democráticos de educação, ora incentivando o uso de procedimentos mais autoritários de educação, ora sugerindo a família a recorrer a terceiros para resolver a problemática. Notamos que a Escola, na relação com a família, parecia atribuir à mesma responsabilidades pelo comportamento da criança no âmbito escolar, conferindo à genitora a solução de problemáticas que estariam acontecendo no interior da instituição escolar, “... era pra mim ver o que que eu poderia fazer...”.

Diante das queixas da Escola em relação a Artur, percebemos o uso, pela genitora, de diversas estratégias educativas junto à criança para modificar seu comportamento na Escola. Conforme já discutido anteriormente, Adriana afirmou que buscava ainda ir à Escola periodicamente para acompanhar e resolver tal situação, o que nem sempre era possível devido à distância geográfica e à falta de transporte. Apesar do uso de diferentes formas para solucionar as queixas escolares de Artur, Adriana indicou em suas falas dificuldades para resolver essa problemática, o que gerava desgaste e causava preocupações para a família, tendo em vista que alguns comportamentos de Artur na Escola colocavam, inclusive, a criança em risco:

“... Tem uma casa lá também [no interior da Escola], que parece que é pertinho, uma casa de máquina, que o Artur gosta de ir nessa casa que tem essas máquinas. Aí uma vez a tia falou pra Alice que o Artur quase que virou carne moída que ele entrou dentro dessa máquina e parece que um homem foi lá, sei que estava ele e os coleguinhas (...) É uma casa que tem lá, que tem um mundo de máquina (...) É abandonada. Aí a tia me chamou lá, né?, pra... me chamou não, mandou um recado pela menina que ele estava indo nessa casa, que era perigoso machucar nessas máquinas e era perigoso ter cobra lá debaixo desses trem e realmente eu concordei com ela, né?, que é muito perigoso. Aí a gente conversou com ele, meu esposo conversou com ele, aí parece que ele parou de ir lá nessa casa...". (Genitora Adriana)

“... O Artur ele lá, agora nessa Escola aqui, ele tá dando muito trabalho pra mim...”. (Genitora Adriana)

“... Porque na questão da obediência, né? (...) Acho difícil, mas a gente... A gente... Igual, a gente tenta, né? Fazer o melhor pro filho da gente, ensinar o melhor, né? Mas às vezes a gente tenta tanto, e ainda é pouco ainda, né? Que a gente faz...". (Genitora Adriana)

Nos relatos de Adriana, características do campo (existência de animais peçonhentos, como cobras) e características da Escola (presença de máquinas no seu interior) apareceram como elementos que influenciavam as significações da família sobre a questão da segurança da criança na instituição escolar, mobilizando a família a buscar junto à Escola garantir a segurança do filho por meio da mudança de seu comportamento. Adriana mencionou o quanto as intervenções da família junto a Artur não resolviam a problemática envolvendo o filho na 
Escola, o que parecia gerar sentimentos de frustrações na família pela situação e contribuía para manter tensões na relação da família com a Escola.

\subsection{As queixas sobre o comportamento de Iago na Escola}

Inês afirmou que a Escola buscava se relacionar com a família para, estritamente, discutir queixas relativas ao comportamento de Iago. Tal postura da Escola em relação à família foi alvo de críticas de Inês, conforme consta no relato a seguir:

“... Eu até questionei com a Vilma, fui bem irônica mesmo, falei: 'Engraçado Vilma você me desculpa, mas pra reclamar do Iago, falar que o Iago bateu no fulano, no sicrano que fez e aconteceu, você lembrou do meu telefone? Agora pra me ligar pra me falar que o Iago está bem, pra me falar que o Iago está isso, está aquilo, pra me dar notícia das coisas que estão acontecendo, vocês não lembram o número do meu telefone? Igual pra reclamar dele isso vocês lembram?' (...) 'Não, que não é assim não'. Elas contorcem de uma forma, sabe? Elas saem de uma situação de uma forma incrivel...”. (Genitora Inês)

Na fala de Inês, percebemos que a genitora mencionou ter questionado, junto à direção escolar, os momentos escolhidos pela instituição para se relacionar com a família e indicou seu desejo de que a relação entre Escola e pais ocorresse tendo em vista metas diferenciadas, como para conversarem, de uma forma mais ampla, sobre o cotidiano da criança na instituição. A forma como ocorriam a escuta a e argumentação da Escola sobre as queixas da família parecia contribuir para que a relação Escola e pais fosse vista, por Inês, como sendo insatisfatória.

Em outros relatos, Inês teceu outras críticas às ações da Escola junto às famílias e às crianças:

“... Eles nunca sabem de nada (...) O Iago já sumiu " $R$ " [muitas] coisas na Escola. Liga lá pra saber ninguém sabe de nada (...) Você entendeu? Eu pergunto 'Escuta, como que vocês, um professor de criança de cinco anos simplesmente as crianças me alega que não fica ninguém com eles no recreio, no lanche?'. Por isso que o Iago some tudo porque criancinha de cinco anos tem umas que têm mais responsabilidade de guardar as coisinhas tudo, só que tem outros, no caso do Iago, deixa tudo jogado. Então se a professora está lá junto: 'Iago, ó, vem catar suas coisinhas, guardar dentro da sua lancheira pra ir embora bonitinho'. Menina mas já foram cinco toalhinhas! Duas garrafinhas térmicas, lancheira já foram duas! (...) Aí vai 'Não, porque não fica sozinho de jeito nenhum. Isso fica gente junto'. E aí? Só que eu acredito nas crianças. Que criança não mente, é muito difícil uma criança mentir...". (Genitora Inês)

“... Ali um dia que eu tive lá (...) eu fiquei lá de fora esperando a van, né? Aí eu estou lá de fora esperando assim... Eu só observando... Aí... é... as professoras começaram a sair das salas com os alunos, né? Não tinha dado o sinal ainda. E eu fui vendo uma professora, duas professoras, fui vendo as salas saindo... E cada professora que ia saindo com seus alunos ficava junto com seus alunos até 
no horário do sinal. Sabe?, ficava meio perto... Teve uma que eu estava mais perto dela que ela saiu da sala, ela nem não misturou com as outras crianças... Ela ficou com a turminha dela ali, ficou brincando de amarelinha e tal com os alunos dela... Aí a hora que eu vi a Dona Pamela saindo da sala, ela foi, falou tchau pros meninos e vazou pra secretaria, os meninos xiiiii esparramou. O Iago foi lá pra aquele parquinho brincar... e é onde some as coisas dele! Aí eu falei assim 'Ah... agora eu estou vendo como que some as coisas do Iago' (...) Você entendeu? E ela simplesmente... Aí ficou uns dez minutos! Dez minutos é muita coisa pra uma criança que está com sede de brincar... Em dez minutos ele machuca, em dez minuto ele perde as coisas, você entendeu? Aí eu virei pras professoras que eu vi brincando de amarelinha, deu o sinal ai que ela foi 'Tchau, meus filhos, tchau beijinho, tchau, tchau'. Aí eu chamei ela, falei 'Fulana, você é professora de que série?', mas nem lembro mais agora. Falei: 'Olha, eu quero te dar os parabéns'. Eu fui irônica! Falei 'Olha eu quero te dar os parabéns porque você está uma excelente professora, diferente da Pamela, e falei o nome, que simplesmente saiu de sala, largou os meninos, crianças de cinco aninhos, soltou os meninos aí e voltou pra sala'. É isso que eu questiono, você entende? O carinho, o capricho de zelar, de olhar... 'Ai, porque eu amo meus filhos, porque eu amo isso' ama nada, se amasse não deixava eles livre assim solto do jeito que ela faz, e vem falar pra mim que faz, que olha. Não olha. Se eu vi fazendo esse dia, é óbvio que ela faz direto...". (Genitora Inês)

Notamos que Inês se colocou, em suas falas, como sendo uma genitora preocupada com o filho e que buscava se relacionar com a instituição escolar. Inês mencionou a realização de tentativas de aproximação com a Escola e sua dinâmica por diferentes formas (conversa com profissionais, observações e escuta de crianças) para obter informações sobre o filho e sobre práticas de cuidado e educação da criança na Escola. Concomitantemente, a genitora indicou como a conversa com a Escola, a fim de obter dados sobre a criança ou para discutir questões relacionadas ao cuidado do filho na Escola (como a supervisão das crianças nos horários de recreio e saída), era permeada por tensões e dificuldades. Ao realizar queixas sobre e para a Escola, notamos que a genitora não se aliou às justificativas e dizeres dos profissionais, questionando a veracidade das falas da instituição escolar. Tais falas, segundo Inês, iam de encontro às falas das crianças, consideradas por Inês como sendo verdadeiras. Nos relatos de Inês percebemos fragilidades na relação, no diálogo entre Escola e família. Dificuldades na relação entre as instituições escolar e familiar também foram indicadas nos relatos a seguir:

“... O que eu sinto forte ali é exclusão. O Iago está sendo excluído, tanto pelos funcionários da Escola, como os coleguinhas porque, sabe?, porque está tendo muita briga. Eu acho que o problema do Iago, por ele não falar direito, as criança não devem entender... Isso tem... as criança caçoa, tira sarro dele, sabe?, e ele fica agitado, ele fica nervoso com isso, entendeu? Ai que que acontece?, parte pra briga. Aí fica brigando...". (Genitora Inês)

“... Ele [Iago] está na primeira fase, introdutório, um negócio assim... Eu não entendo, sabe?, que que é. Então eu não sei se nessa fase ele já está sendo alfabetizado, se ele não está, que ano que ele vai ser alfabetizado, que já é alfabetização. Aí ela [Profissional Vilma] falou: 'Não, mas ele já está sendo alfabetizado', está nada porque ele... não liga com ele (...) Então eu não sei te falar realmente assim o que que ele faz o que que deixa de fazer...". (Genitora Inês) 
“... Eu não tenho a mínima ideia realmente (do que as crianças fazem na Escola) porque eu não vejo, eu não vejo o trabalho dele, eu não vejo produção, eu não vejo, sabe? O Iago, eu falo do Iago por causa dessa questão do Iago não participar, né?, que o Iago, né?, ela fala que eles dão um folhinha pro Iago fazer uma tarefinha. 'Ah, não quero mais', ele já embola e joga fora. Então o que que ela tinha que fazer? Pegar outra folha, 'Vem aqui Iago, você vai fazer que isso aqui é um trabalhinho que você tem que fazer', pápápá, conversar, explicar pra ele e insistir. Elas não insistem, ele pegou e jogou fora?, elas largam ele pra lá...”. (Genitora Inês)

“... Então realmente assim, pra mim eles falam que fazem isso, que fazem aquilo... Tá certo que de vez em quando eu vejo ele contar alguma coisinha, ele tentar cantar alguma musiquinha que aprendeu na Escola, então não estou falando que é zerado totalmente, que não aprende nada. Eu vejo que ele aprende alguma coisinha, mas muito pouquinho, pelo, pelo, eu comparo, não é que eu comparo assim comparação, mas eu vejo assim pela Íris que entrou junto no mesmo ano, sabe? A Íris sabe muito mais do que ele, mas assim está certo que o Iago tem uma certa dificuldade maior que a Íris, que a Íris é uma menina mais calma e tal, mas cadê essa professora?, pra estar ajudando o Iago, estar vendo que o Iago tem essa dificuldade, de estar ajudando ele mais...". (Genitora Inês)

Nos trechos apresentados, percebemos o quanto a relação da Escola com a criança era vista pela família como sendo inadequada, sendo que Inês, inclusive, utilizou o termo "exclusão" para caracterizar, se referir a tal relação. Na relação com a Escola, Inês parecia sentir a existência de um desinteresse por parte da instituição escolar em relação a Iago, indicado pela genitora como sendo uma criança que apresentava maiores dificuldades no âmbito escolar, como para se comunicar com os colegas e realizar atividades. A genitora demonstrou não concordar com a postura pedagógica dos profissionais, indicando a necessidade de a instituição escolar realizar um trabalho direcionado à criança e que considerasse suas características e especificidades.

Segundo Inês, a ida da criança para a Escola Flamboyant e a relação entre a instituição escolar e pais estava se constituindo para a família como uma experiência desafiadora e desgastante, “... Tá sendo um ano muito difícil pra ele, pra mim, muito difícil...!... ”. Notamos ainda, segundo as falas de Inês, o quanto a família se colocava na posição daquela que buscava realizar ações para melhorar a vivência da criança na instituição e que, segundo a genitora, não estavam sendo bem-sucedidas. Em outros relatos Inês apontou que, diante dos insucessos nas conversas com a Escola e, ainda, da avaliação de que a instituição escolar não estaria realizando um bom trabalho junto ao filho e que estaria mantendo práticas excludentes junto à criança no âmbito escolar, a mesma buscou outras formas de intervir na dinâmica institucional, conforme consta no trecho a seguir:

“... Eu fui lá na Prefeitura, na Secretaria de Educação e fiz a denúncia da exclusão, de tudo que estava acontecendo lá com o Iago, você entendeu?...”. (Genitora Inês) 
Segundo Inês houve a "denúncia” na Prefeitura Municipal das práticas da Escola junto a Iago. Tal ação evidenciou a existência de concepções da família de que o oferecimento de uma Educação Infantil no campo com qualidade é um direito da criança e da família e que deve ser garantido pelo Poder Público. Concomitantemente tal ação indicou que a família vislumbrava limites de escuta/resolução de suas queixas na relação direta com a Escola, recorrendo a outras instâncias, a mediadores externos para solucionar as problemáticas envolvendo o filho no âmbito escolar.

Em outros relatos, a entrevistada mencionou que, a partir da realização de tal “denúncia” na Prefeitura Municipal, ocorreu, na Escola Flamboyant, uma reunião que contou com a presença da genitora, da inspetora escolar e de profissionais da Escola, como a professora de Iago, na qual a família apresentou algumas de suas angústias e queixas advindas da ida da criança para a Escola, conforme indicam os relatos a seguir:

“... Quando o Iago começou a estudar, eu até questionei isso no dia que teve a reunião com a inspetora, sabe? No começo do ano eles falaram assim: 'Ah, que o Iago, porque que o Iago tá... Ah mais é normal'. Eles falaram assim que era normal uma criança estar com rejeição de querer ir pra Escola. Eu falei: 'Hã, hã, meu filho não'. O Iago, a criança quando entra pra Escola, se for pra ela rejeitar, de não querer ir pra Escola, ela já vai começar a rejeitar a Escola desde o começo do ano (...) Só que as coisas foram acontecendo, as professoras brigando, pondo de castigo, mais não sei o quê, mais não sei o quê... Aí foi tomando raiva (...) Ele já não sente mais aquela vontade, aquele prazer... Se você perguntar pra ele: 'Iago você quer mudar de Escola?', 'Eu quero'. Ele é louquinho pra sair dali...". (Genitora Inês)

“... O Iago estava chegando muito machucado em casa, chorando. Ele até hoje, apesar que já deu uma melhoradinha, mas há uns meses atrás ele estava chorando de manhã que não queria ir pra Escola. Aí ele inventava que estava com dor na perna, que estava com dor de barriga, que estava com dor de cabeça... Cada dia ele inventava uma coisa, sabe?... pra não ir. Eu falei isso na reunião lá, sabe? Aí a Pamela, que eu cheguei... tomei uma birra dessa mulher... a Pamela virou pra mim e falou assim: 'Ah, isso não é verdade, o Iago nunca reclamou, ele adora aqui', ai eu falei 'Mas é claro que ele vai reclamar aqui pra que? Ele tem que reclamar é lá dentro da casa dele pra ele tentar de todas as formas de não vir a Escola, depois que ele já está aqui dentro... pra que que ele vai reclamar?'. Não é verdade? (...) A Pamela chegou a falar que eu estava mentindo questão dele chegar machucado (...) Eu falei assim 'Você acha que eu estou mentindo? Você está me chamando de mentirosa? Pra que que eu vou mentir sobre uma coisa tão séria dessa?' (...) 'Falar que um filho está chegando machucado em casa. Eu não estou, eu quero que vocês me entendam o seguinte...', que nem eu falei pra eles, '... Eu não estou acusando a Escola, não estou acusando você, não estou acusando ninguém. Eu só estou alegando que é o seguinte: o Iago chega machucado aqui hoje aí quando é amanhã eu ligo lá 'Vilma que que está acontecendo? Por que que o Iago machucou?', 'Ah, o Iago está machucado? Não sei disso, não estou sabendo não...'. Eles nunca sabem de nada...”. (Genitora Inês)

Os relatos apresentados indicam como tal encontro entre a família de Iago e a Escola Flamboyant se constituiu, para Inês, como um espaço onde a família expôs suas preocupações 
em relação ao filho e sua ida para a instituição escolar; realizou queixas sobre a Escola no que tange à forma de lidar/educar a criança e no que se refere à falta de informações de profissionais da instituição escolar sobre o cotidiano de Iago neste local; questionou discursos institucionais sobre a criança e sobre a família. Ao mesmo tempo, tal encontro se constituiu, para a genitora, como sendo um momento em que a Escola buscou justificar e negar práticas institucionais criticadas pela família. Inês, em sua fala, apontou o quanto a família e a Escola defendiam visões diferenciadas sobre fatos envolvendo a criança, como acidentes, e o quanto a genitora e profissionais pareciam manter-se em uma relação voltada para confrontos e que não conseguiam avançar na direção do aperfeiçoamento das práticas de compartilhamento do cuidado e educação da criança.

Ainda sobre esta reunião, Inês afirmou: “... só que não adiantou nada que a inspetora foi lá, fez a reunião, só que pra mim ficou aquela assim, que a inspetora acreditou no que eles falavam, ficou de fazer uma avaliação não sei com o que, com a equipe não sei de quem, até hoje essa avaliação não foi feita... E nem vai ser feita porque praticamente tá no fim do ano, né?...”. Inês indicou que também na relação com a inspeção escolar não foi atribuída uma credibilidade às falas da família e que não ocorreu um acolhimento de suas queixas para resolver a problemática envolvendo Iago na Escola.

Diante dos inúmeros encontros problemáticos com a Escola, Inês mencionou o quanto sentia a relação com a instituição escolar desgastada e como avaliava a mesma negativamente:

“... Eu já tomei uma certa bronca da Escola por causa disso, dessa luta minha ali...”. (Genitora Inês)

“... Eu tomei muita raiva deles. Deles todos, sabe? (...) Por causa de tudo isso que está acontecendo, que é meu filho que está no meio dessa, dessa batalha... Então quer dizer assim, eles tentam me passar que, que é tudo perfeito, que é tudo maravilhoso, mas não me convence, você entende? Não me convence que eles estão realmente trabalhando, que eles estão empenhado em fazer alguma coisa pelo Iago. Eu não vejo esse, esse empenho, mesmo de longe. Que quando a gente sente o empenho da pessoa, a gente vê pela criança. Aí ó, essa história, desse tal bilhete. Não sei que bilhete é esse, bilhete pedindo dinheiro, pra comprar um CD, comprar um DVD não sei de que, não sei... E eu já cansei de falar pra eles, 'O Iago ele não fala, ele não me explica, ele não me dá recado', 'Ah, mas aqui pra nós ele fala'. Tudo bem mas dá pra ele o bilhete lá mas não deixa de pedir pra outra pessoa estar avisando e me falando. Eu fico sem saber o que tá acontecendo! ...”. (Genitora Inês)

Notamos o quanto a relação entre a Escola e a família de Iago tornou-se fragilizada. A mesma estava sendo vivenciada por Inês como sendo uma "luta", "uma batalha" na qual não havia interesse da Escola em melhorar suas práticas junto à criança e nem suas ações de escuta, de diálogo e atendimento da família. 
Sobre a escuta da família, em outros relatos, Inês apontou sua concepção de que a instituição escolar avaliava negativamente suas iniciativas de conversar com os profissionais, “... Nossa, essas mulheres de certo quando eu ligo lá, fala assim que é a Inês, mãe do Iago 'Nossa senhora, aquela mulher chata que está no telefone'. Tenho certeza que elas fazem isso...”. A ideia de que a Escola não possuía interesse pela criança e de que era movida apenas por interesses financeiros foi também defendida por Inês, “... Assim pra mim o objetivo daquela Escola é só trabalhar pra ganhar o dinheiro e pronto porque ali eles não preocupam com menino não (...) Eles estão ali trabalhando assim é... mesma coisa de uma empregada doméstica. Chega aqui, vai, limpa a casa, tudo, faz a obrigação dela e vai embora. Isso é o que eu vejo ali...”, o que indicou novamente distanciamentos na relação Escola e família.

Diante das dificuldades vivenciadas na relação com a instituição escolar, Inês mencionou a busca de orientações de profissionais da Psicologia e da Medicina para auxiliar a família e afirmou ter cogitado outras estratégias para solucionar a problemática, conforme consta nos relatos a seguir:

“... Teve uma época, quando estava acontecendo essas coisas, tudo, que eu cheguei a falar que eu não ia mais mandar ele pra Escola esse ano e nem o ano que vem se fosse preciso, sabe?, até eu ver que que eu ia fazer da minha vida, mas aí... com a orientação da psicóloga, da Neusa, né?, a neurologista falou 'Não, você não pode deixar ele, deixar, por mais que esteja acontecendo você não pode deixar de mandar ele porque se você deixar de mandar ele, ele vai tomar como se ele tivesse conquistado o que ele queria, de não ir pra Escola'. Então mal ou ruim ele tem que ir... Tá certo que está acontecendo as coisas lá tudo mas aí o que que acontece?, você tem que ficar em cima, cobrando e exigindo...". (Genitora Inês)

“... Eu cheguei a pensar em sair daqui, voltar pra cidade, pagar aluguel, por causa dele, pra ele mudar da Escola (...) pra outra Escola municipal, né?, mas isso, é... a minha psicóloga aconselhou a não por enquanto que o problema não é a Escola... é a Escola também porque a Escola está tendo esse problema de não estar sabendo receber o Iago. Por isso que a psicóloga dele agora (...) falou que na primeira semana de aula ela já quer ir lá, pra conhecer a sala de aula. Professores, diretor, tudo. E ela quer ver se trabalha pelo menos, eu não entendi se é uma vez a cada quinze dias, uma vez por mês. Porque ela quer ir passar o dia lá, pra ajudar, isso é, isso pro Iago, pra estar ajudando o Iago. Ela quer estar ajudando, tanto a professora nova dele que vai começar com ele o ano que vem, como o diretor, as outras pessoas, e os próprios coleguinhas a estar ajudando a trabalhar com o Iago...". (Genitora Inês)

“... Essa [professora] agora eu nem conheço ainda... Nem estou fazendo muita questão porque está acabando o ano, sabe? (...) Porque eu tomei uma certa birra ali. Eu estou tentando fazer de tudo, estou trabalhando com a minha psicóloga pra mim aceitar essa Escola porque eu não tenho outra opção. Porque se eu tivesse outra opção eu mudava. Se eu tivesse condições, se eu tivesse outra opção, se eu tivesse condição financeira eu tirava o Iago dali. Entendeu? Mas infelizmente não, não temos nem condição financeira, nem opção de Escola...". (Genitora Inês) 
Os trechos acima indicam o quanto a família de Iago buscou encontrar caminhos para solucionar a problemática envolvendo a ida da criança para a Escola. A ideia de retirar a criança da instituição escolar, bem como de ir para a cidade em busca de outra Escola é mencionada por Inês. No entanto, notamos como a relação entre a Escola e a família de Iago vinha se mantendo devido às intervenções de outros profissionais, externos à Escola, que indicavam a importância de a criança permanecer na instituição escolar. Inês indicou ainda que a falta de outra instituição na comunidade rural aonde residiam e a precariedade de recursos financeiros também eram importantes elementos - que atravessam o campo e vida das famílias do campo - que contribuíam para a permanência da criança na Escola Flamboyant.

Diante da permanência de Iago na Escola Flamboyant, Inês relatou a necessidade de auxílio psicológico para trabalhar sua relação emocional/afetiva com a instituição. Em outros relatos, percebemos o quanto a relação entre a Escola e a família vinha sendo mediada pelas orientações de profissionais da Psicologia, que sugeriram - o que foi aceito pela família - de que o genitor de Iago passasse a ir à Escola ao invés da genitora. Inês mencionou ainda que a psicóloga que acompanhava Iago propôs ainda frequentar e atuar junto à Escola para auxiliar a criança, a família e os profissionais da instituição escolar.

A busca por mediadores externos, neste caso, desponta como uma prática que indica a existência de instrumentos ineficientes na relação Escola e família, mas também para a mobilização dos pais em busca da melhoria da relação e das práticas de cuidado e educação dispensados à criança na e pela Escola.

\subsection{Adoecimento e acidente da crianca na Escola}

Famílias entrevistadas relataram a ocorrência de adoecimento e acidente envolvendo a criança na instituição escolar. Fabíola indicou que a relação entre a Escola e família, nestas situações, era atravessada por silenciamentos:

“... Outra coisa que eles [profissionais] faz de errado na Escola (...) O Fabrício teve febre esse ano na Escola, eles preferiu dar banho no Fabrício na Escola, do que me ligar pra me avisar. Ficou com ele com febre altíssima na Escola (...) Não posso te mostrar o caderno de recado dele, porque ele perdeu o caderno de recado lá na Escola, os meninos rasgou o caderno dele tudo. Ele esqueceu lá e os outros meninos rasgou. Ele tinha um bilhetim que ela mandou pra mim... Eles deu banho nele eu achei errado, porque hoje eu tenho tanto medo desse caso de pedofilia Luciana, eles preferiu, não sei quem deu banho nele lá, deu banho nele lá na Escola, e me mandou ele de noitão com febre. Ele chegou aqui, estava com febre altíssima (...) Não fiquei sabendo de nada... Eles não me ligou, não me falou nada. Porque lá na Escola fica uma van, era pra ficar, não sei se tá ficando. Uma van pra esses casos, crianças que passam mal, crianças que cai e machuca, pra trazer de volta pra casa pras mães. 
Esse dia lá tinha a van e eles não mandou pra mim, mas eu não reclamei pra Escola, porque logo no início se vocêfor implicar com tudo (...) E você sabe o que que ele tinha? Ele estava com pneumonia. E eles não me trouxe o Fabrício...". (Genitora Fabiola)

Percebemos que Fabíola criticou os procedimentos adotados pela Escola diante de um quadro febril de Fabrício, indicando incômodos sobre a ausência de diálogos na relação Escola e família frente ao acontecimento. A genitora defendeu a ideia de que a Escola deveria aliar-se às famílias para resolver a problemática, indo além da comunicação aos pais, por meio de bilhetes e após o término do dia escolar, sobre o ocorrido. Fabíola afirmou existir na Escola um veículo para levar as crianças para suas residências, em caso de adoecimento e acidentes, e criticou o fato de a Escola não ter utilizado deste meio na situação relatada. Apesar das ressalvas sobre os procedimentos adotados neste caso, Fabíola mencionou que não realizou queixas à Escola, "... eu não reclamei pra Escola, porque logo no início se você for implicar com tudo...". Tal postura da genitora indicou a existência de uma preocupação e de um cuidado por parte da família com o início da relação com a Escola.

Em outro relato Fabíola narrou mais um momento permeado por silenciamentos da Escola e também da família, conforme consta na fala a seguir:

“... E outro dia, isso já mais agora recente, ele caiu, uma criança empurrou ele, ele caiu e machucou o nariz tudo lá na Escola... Hora que chegou aqui que o Moisés me entregou, pensei que estava quebrado o nariz dele (...) De novo eles não me avisou (...) Ninguém me ligou, não fez nada... e isso eu acho errado da Escola (...) E trouxe o menino machucado, eu tive que... e de noite, você sabe que tudo é mais difícil (...) Não fiquei sabendo. Ele machucou lá, eles ficaram com ele machucado o dia inteiro e me trouxe machucado de noite (...) [A noite] Tudo é mais difícil, pra você ver que o Posto de Saúde do Bairro Mineiro que é mais perto pra nós aqui, não tem traumato de noite e nem pediatra, você deve saber, né? Eu tive que arrumar carro e ir lá pro Posto de Saúde do Bairro Chapada, porque eu pensei que ele estava com o nariz quebrado. Duas coisas que aconteceu lá de errado que eu achei foi isso...". (Genitora Fabíola)

Fabíola criticou novamente o fato de a Escola não comunicar à família um caso de acidente envolvendo a criança no âmbito escolar. A entrevistada apontou ainda como tal procedimento errôneo da Escola toma uma dimensão diferenciada para as famílias no campo, tendo em vista a distância que possuem dos serviços de saúde, localizados na cidade, ainda mais no período noturno. Nesse período, conforme indicou Fabíola, não há no posto de saúde urbano mais próximo da família e médicos especializados em traumatologia e pediatria, tornando a busca da família rural pelo atendimento ainda mais difícil e oneroso.

Apesar das graves consequências que tal ação da Escola trouxe/pode trazer para a família de Fabrício, Fabíola mencionou que não realizou queixas à Escola: 
“... Não cheguei a falar, eu aguentei, esse ano. Agora o ano que vem eu falei, igual eu estava conversando com mamãe, porque eu sempre converso com mamãe e com papai... eu não vou deixar Luciana, porque você não pode deixar tudo (...) Fiquei com receio da Escola, você já começa com a criança num ano, você já começa muito perturbar a Escola, ai vai falar, 'Essa mãe é muito encrenqueira', e já começa até às vezes a encrencar com o filho da gente, por isso que eu não cobrei muito, mas eu achei de errado...". (Genitora Fabiola)

Fabíola manifestou novamente cautela no início da relação com a Escola, demonstrando, inclusive, receios de que as ações da genitora influenciassem as práticas escolares junto à criança. A genitora indicou, porém, a intenção e a necessidade de ir modificando, de forma gradativa, sua relação com a Escola em situações problemáticas envolvendo o filho, a partir da realização de queixas para os profissionais sobre os procedimentos adotados em tais circunstâncias.

Dessa forma, a genitora defendeu a concepção de que a relação com Escola deveria se tornar mais próxima, para o compartilhamento do cuidado da criança entre as instituições familiar e escolar.

A partir da análise e discussão das significações das famílias relativas às situações problemáticas, discutidas anteriormente, apreendemos que familiares indicaram em suas falas elementos que estariam envolvidos com a ocorrência de tais situações, bem como elementos que dificultariam a resolução das mesmas. Tais dados são apresentados nos quadros a seguir: 


\begin{tabular}{|c|c|c|}
\hline Situações & \multicolumn{2}{|c|}{ Elementos envolvidos na ocorrência das situações problemáticas } \\
\hline \multirow[t]{4}{*}{$\begin{array}{l}\text { Ingresso da criança na } \\
\text { Escola }\end{array}$} & $\begin{array}{c}\begin{array}{c}\text { Características das } \\
\text { famílias }\end{array} \\
\end{array}$ & $\begin{array}{c}\text { Trabalho de famílias nas residências contribuía para } \\
\text { tornar o afastamento da criança difícil }\end{array}$ \\
\hline & \multirow[t]{2}{*}{ Características da Escola } & $\begin{array}{l}\text { Inadequação do espaço físico da Escola para crianças } \\
\text { da EI }\end{array}$ \\
\hline & & $\begin{array}{c}\text { Ausência de ações para auxiliar o processo de } \\
\text { adaptação da criança e família à Escola }\end{array}$ \\
\hline & Características do campo & $\begin{array}{l}\text { Distância geográfica, que implicava no transporte da } \\
\text { criança visto com receio pela família }\end{array}$ \\
\hline \multirow{3}{*}{$\begin{array}{c}\text { Queixas sobre } \\
\text { comportamento da } \\
\text { criança na Escola }\end{array}$} & $\begin{array}{c}\text { Características das } \\
\text { crianças }\end{array}$ & $\begin{array}{l}\text { Dificuldades da criança na relação com colegas e } \\
\text { professora e na realização de atividades escolares }\end{array}$ \\
\hline & \multirow{2}{*}{ Características da Escola } & Desinteresse da Escola pela criança \\
\hline & & $\begin{array}{c}\text { Dinâmica que permitia crianças ficarem sem } \\
\text { supervisão de adultos em horários, como no recreio }\end{array}$ \\
\hline $\begin{array}{l}\text { Acidente envolvendo a } \\
\text { criança no âmbito } \\
\text { escolar }\end{array}$ & Características da Escola & $\begin{array}{l}\text { Inadequação do espaço físico da Escola para crianças } \\
\text { da EI }\end{array}$ \\
\hline
\end{tabular}

Quadro 31 - Elementos envolvidos na ocorrência das situações problemáticas - Relatos das famílias

\begin{tabular}{|c|c|c|}
\hline Situações & \multicolumn{2}{|c|}{ Elementos que dificultavam a resolução das situações problemáticas } \\
\hline \multirow[t]{4}{*}{$\begin{array}{l}\text { Ingresso da criança na } \\
\text { Escola }\end{array}$} & $\begin{array}{c}\text { Características das } \\
\text { famílias }\end{array}$ & $\begin{array}{l}\text { Trabalho das famílias nas residências que contribuía } \\
\text { para tornar o afastamento da criança difícil }\end{array}$ \\
\hline & \multirow[t]{2}{*}{ Características da Escola } & $\begin{array}{l}\text { Inadequação do espaço físico da Escola para crianças } \\
\text { da EI }\end{array}$ \\
\hline & & $\begin{array}{c}\text { Ausência de ações para auxiliar o processo de } \\
\text { adaptação da criança e família à Escola }\end{array}$ \\
\hline & Características do campo & $\begin{array}{l}\text { Distância geográfica, que implicava no transporte da } \\
\text { criança visto com receio pela família }\end{array}$ \\
\hline \multirow{7}{*}{$\begin{array}{l}\text { Queixas sobre o } \\
\text { comportamento da } \\
\text { criança na Escola }\end{array}$} & \multirow[t]{2}{*}{$\begin{array}{l}\text { Características das } \\
\quad \text { famílias }\end{array}$} & $\begin{array}{c}\text { Dificuldades da família no processo de educar a } \\
\text { criança }\end{array}$ \\
\hline & & $\begin{array}{c}\text { Precárias condições financeiras da família não } \\
\text { possibilitava sua mudança para a cidade em busca de } \\
\text { outro trabalho e Escola para a criança }\end{array}$ \\
\hline & \multirow[t]{3}{*}{ Características da Escola } & $\begin{array}{c}\text { Formas de a Escola conversar com a família (maior } \\
\text { autoridade) }\end{array}$ \\
\hline & & $\begin{array}{c}\text { Atribuição somente à família da responsabilidade de } \\
\text { educar a criança }\end{array}$ \\
\hline & & $\begin{array}{c}\text { Não escuta e atendimento das queixas da família } \\
\text { sobre ações da Escola }\end{array}$ \\
\hline & \multirow[t]{2}{*}{$\begin{array}{l}\text { Características do campo e } \\
\text { do município }\end{array}$} & $\begin{array}{l}\text { Grande distância geográfica e falta de transporte } \\
\text { escolar para os pais, o que dificultava o encontro e a } \\
\text { conversa da Escola com as famílias }\end{array}$ \\
\hline & & $\begin{array}{c}\text { Ausência de outra Escola na região, o que } \\
\text { impossibilitava a mudança da criança de instituição } \\
\text { escolar }\end{array}$ \\
\hline \multirow{2}{*}{$\begin{array}{c}\text { Adoecimento e } \\
\text { Acidente envolvendo a } \\
\text { criança no âmbito } \\
\text { escolar }\end{array}$} & $\begin{array}{c}\begin{array}{c}\text { Características das } \\
\text { famílias }\end{array} \\
\end{array}$ & Silenciamentos da família na relação com a Escola \\
\hline & Características da Escola & Silenciamentos da Escola na relação com a família \\
\hline
\end{tabular}

Quadro 32 - Elementos que dificultavam a resolução das situações problemáticas - Relatos das famílias 
Nos quadros acima, notamos que as famílias mencionaram diversos elementos que estariam relacionados à ocorrência e resolução das situações problemáticas. Tais elementos se referem às características das famílias/crianças, da Escola, do campo e do município.

No que tange às características das crianças e famílias, notamos que as mesmas se relacionavam com as formas de a criança se comportar na Escola; com dificuldades das famílias no processo de educação da criança e com as condições de vida e de trabalho das famílias nos territórios rurais. Características da Escola também foram citadas como elementos que influenciavam a ocorrência e resolução de situações problemáticas na relação Escola e família. Tais características se relacionavam com a estrutura da Escola e com suas práticas pedagógicas junto à criança e à família, no que se refere à adaptação da família e da criança à Escola e à supervisão das crianças em tempo integral. Tais características da Escola parecem se destacar nas situações problemáticas, tendo em vista o fato de a instituição estar no campo, o que, segundo entrevistadas, colocavam as crianças em situações de maior risco. A forma de a Escola se relacionar com as famílias e de compreender seu papel na educação da criança também foi citado como importante elemento nesse contexto.

Características do campo e do município também foram citadas como elementos que influenciavam a resolução de situações problemáticas, como a ausência de outra Escola na região, o que limitava a possibilidade de escolha da família por outro atendimento, que considerasse mais apropriado; a distância geográfica entre Escola e residências das famílias, o que tornava a ida da criança para a instituição escolar mais difícil para as famílias; e ausência de transporte escolar para os pais, o que dificultava a ida dos mesmos à Escola.

\subsubsection{Aproximações e distanciamentos das significações das profissionais e famílias sobre situações problemáticas na relação entre a Escola e as famílias}

A partir da análise das significações das profissionais e das famílias sobre as situações problemáticas, notamos que as mesmas ora se aproximaram e ora se afastaram, conforme pode ser visualizado nos quadros a seguir: 


\begin{tabular}{|c|c|c|c|}
\hline \multirow{2}{*}{$\begin{array}{c}\text { Situações } \\
\text { problemáticas }\end{array}$} & \multicolumn{3}{|c|}{ Elementos envolvidos na ocorrência das situações problemáticas } \\
\hline & & Profissionais & Famílias \\
\hline \multirow[t]{5}{*}{$\begin{array}{c}\text { Ingresso da } \\
\text { criança na Escola }\end{array}$} & \multirow[t]{2}{*}{$\begin{array}{l}\text { Características das } \\
\text { famílias/crianças }\end{array}$} & $\begin{array}{l}\text { Comportamento da criança de } \\
\text { indisciplina, influenciado pelo } \\
\text { pertencimento ao movimento } \\
\text { social }\end{array}$ & -------------- \\
\hline & & & $\begin{array}{l}\text { Trabalho das famílias nas } \\
\text { residências, o que contribuía } \\
\text { para tornar o afastamento da } \\
\text { criança difícil }\end{array}$ \\
\hline & \multirow[t]{2}{*}{$\begin{array}{c}\text { Características da } \\
\text { Escola }\end{array}$} & ----- & $\begin{array}{c}\text { Inadequação do espaço } \\
\text { físico da Escola para } \\
\text { crianças da EI }\end{array}$ \\
\hline & & & $\begin{array}{l}\text { Ausência de ações da Escola } \\
\text { para auxiliar o processo de } \\
\text { adaptação da criança e } \\
\text { família à Escola }\end{array}$ \\
\hline & $\begin{array}{c}\text { Características do } \\
\text { campo }\end{array}$ & -------------- & $\begin{array}{c}\text { Distância geográfica, que } \\
\text { implicava no transporte da } \\
\text { criança visto com receio pela } \\
\text { família }\end{array}$ \\
\hline $\begin{array}{c}\text { Queixas sobre } \\
\text { frequência e } \\
\text { aprendizagem da } \\
\text { criança }\end{array}$ & $\begin{array}{l}\text { Características das } \\
\text { famílias }\end{array}$ & $\begin{array}{l}\text { Práticas familiares de } \\
\text { educação da criança }\end{array}$ & ------------- \\
\hline \multirow{6}{*}{$\begin{array}{l}\text { Queixas sobre o } \\
\text { comportamento da } \\
\text { criança na Escola }\end{array}$} & \multirow[t]{3}{*}{$\begin{array}{l}\text { Características das } \\
\text { famílias/crianças }\end{array}$} & $\begin{array}{l}\text { Ambiente familiar } \\
\text { "desestruturado" }\end{array}$ & ----------- \\
\hline & & $\begin{array}{l}\text { Práticas familiares de } \\
\text { educação da criança }\end{array}$ & ------------- \\
\hline & & $\begin{array}{l}\text { Dificuldades da criança na } \\
\text { relação com colegas e } \\
\text { professora e na realização de } \\
\text { atividades escolares }\end{array}$ & $\begin{array}{l}\text { Dificuldades da criança na } \\
\text { relação com colegas e } \\
\text { professora e na realização de } \\
\text { atividades escolares }\end{array}$ \\
\hline & \multirow[t]{3}{*}{$\begin{array}{c}\text { Características da } \\
\text { Escola }\end{array}$} & $\begin{array}{l}\text { Práticas escolares de educação } \\
\text { da criança }\end{array}$ & - ----------- \\
\hline & & ------------ & $\begin{array}{c}\text { Desinteresse da Escola pela } \\
\text { criança }\end{array}$ \\
\hline & & $\begin{array}{c}\text { Dinâmica que permite } \\
\text { crianças ficarem sem } \\
\text { supervisão de adultos em } \\
\text { horários, como no recreio }\end{array}$ & $\begin{array}{c}\text { Dinâmica que permite } \\
\text { crianças ficarem sem } \\
\text { supervisão de adultos em } \\
\text { horários, como no recreio }\end{array}$ \\
\hline \multirow[t]{2}{*}{$\begin{array}{c}\text { Acidentes } \\
\text { envolvendo a } \\
\text { criança no âmbito } \\
\text { escolar }\end{array}$} & \multirow[t]{2}{*}{$\begin{array}{c}\text { Características da } \\
\text { Escola }\end{array}$} & $\begin{array}{l}\text { Dinâmica que permite } \\
\text { crianças ficarem sem } \\
\text { supervisão de adultos em } \\
\text { horários, como no recreio } \\
\end{array}$ & -------------- \\
\hline & & $\begin{array}{l}\text { Inadequação do espaço físico } \\
\text { da Escola para crianças da EI }\end{array}$ & $\begin{array}{c}\text { Inadequação do espaço } \\
\text { físico da Escola para } \\
\text { crianças da EI }\end{array}$ \\
\hline
\end{tabular}

Quadro 33 - Elementos envolvidos na ocorrência das situações problemáticas - Relatos das profissionais e famílias 


\begin{tabular}{|c|c|c|c|}
\hline \multirow{2}{*}{$\begin{array}{c}\text { Situações } \\
\text { problemáticas }\end{array}$} & \multicolumn{3}{|c|}{ Elementos que dificultavam a resolução das situações problemáticas } \\
\hline & & Profissionais & Famílias \\
\hline \multirow{5}{*}{$\begin{array}{l}\text { Ingresso da } \\
\text { criança na } \\
\text { Escola }\end{array}$} & \multirow[t]{2}{*}{$\begin{array}{l}\text { Características das } \\
\text { famílias/crianças }\end{array}$} & $\begin{array}{c}\text { Possuíam dificuldades de se } \\
\text { adaptarem às regras da Escola }\end{array}$ & -------------- \\
\hline & & & $\begin{array}{c}\text { Trabalho das famílias nas } \\
\text { residências, o que contribuía } \\
\text { para tornar o afastamento da } \\
\text { criança difícil }\end{array}$ \\
\hline & \multirow[t]{2}{*}{$\begin{array}{l}\text { Características da } \\
\text { Escola }\end{array}$} & --------------- & $\begin{array}{c}\text { Inadequação do espaço físico da } \\
\text { Escola para crianças da EI } \\
\end{array}$ \\
\hline & & & $\begin{array}{l}\text { Ausência de ações para auxiliar } \\
\text { o processo de adaptação da } \\
\text { criança e família à Escola }\end{array}$ \\
\hline & $\begin{array}{c}\text { Características do } \\
\text { campo }\end{array}$ & ------------ & $\begin{array}{c}\text { Distância geográfica, que } \\
\text { implicava no transporte da } \\
\text { criança visto com receio pela } \\
\text { família }\end{array}$ \\
\hline \multirow{10}{*}{$\begin{array}{l}\text { Queixas sobre o } \\
\text { comportamento } \\
\text { da criança na } \\
\text { Escola }\end{array}$} & \multirow[t]{5}{*}{$\begin{array}{l}\text { Características das } \\
\text { famílias/crianças }\end{array}$} & $\begin{array}{c}\text { Ambiente familiar } \\
\text { "desestruturado" }\end{array}$ & ------------ \\
\hline & & $\begin{array}{c}\text { Concepção das famílias de que } \\
\text { a educação da criança caberia } \\
\text { somente à EI }\end{array}$ & --------------- \\
\hline & & $\begin{array}{c}\text { Concepção da família de que a } \\
\text { Escola era desinteressada pela } \\
\text { criança }\end{array}$ & -------------- \\
\hline & & & $\begin{array}{l}\text { Dificuldades da família no } \\
\text { processo de educar a criança }\end{array}$ \\
\hline & & & $\begin{array}{c}\text { Precárias condições financeiras } \\
\text { da família que não possibilitava } \\
\text { sua mudança para a cidade em } \\
\text { busca de outro trabalho e Escola } \\
\text { para a criança }\end{array}$ \\
\hline & \multirow[t]{3}{*}{$\begin{array}{l}\text { Características da } \\
\text { Escola }\end{array}$} & ----- & $\begin{array}{c}\text { Forma de a Escola conversar } \\
\text { com a família (maior } \\
\text { autoridade) }\end{array}$ \\
\hline & & & $\begin{array}{l}\text { Atribuição somente à família da } \\
\text { responsabilidade de educar a } \\
\text { criança }\end{array}$ \\
\hline & & & $\begin{array}{l}\text { Não escuta e atendimento das } \\
\text { queixas da família sobre ações } \\
\text { da Escola }\end{array}$ \\
\hline & \multirow[t]{2}{*}{$\begin{array}{l}\text { Características do } \\
\text { campo e do município }\end{array}$} & $\begin{array}{c}\text { Grande distância geográfica e } \\
\text { falta de transporte escolar para } \\
\text { os pais, o que dificultava ida da } \\
\text { família à Escola } \\
\end{array}$ & $\begin{array}{c}\text { Grande distância geográfica e } \\
\text { falta de transporte escolar para } \\
\text { os pais, o que dificultava ida da } \\
\text { família à Escola }\end{array}$ \\
\hline & & & $\begin{array}{l}\text { Ausência de outra Escola na } \\
\text { região, o que tornava impossível } \\
\text { a mudança da criança de } \\
\text { instituição escolar }\end{array}$ \\
\hline \multirow[t]{2}{*}{$\begin{array}{c}\text { Acidentes } \\
\text { envolvendo a } \\
\text { criança no } \\
\text { âmbito escolar }\end{array}$} & \multirow[t]{2}{*}{$\begin{array}{l}\text { Características da } \\
\text { Escola }\end{array}$} & $\begin{array}{l}\text { Dinâmica que permitia crianças } \\
\text { ficarem sem supervisão de } \\
\text { adultos em horários, como no } \\
\text { recreio, e que resultava na falta } \\
\text { de informação da Escola sobre } \\
\text { acontecimentos envolvendo a } \\
\text { criança em tais horários }\end{array}$ & ---------- \\
\hline & & ------------ & $\begin{array}{l}\text { Silenciamentos na relação com } \\
\text { a família }\end{array}$ \\
\hline
\end{tabular}

Quadro 34 - Elementos que dificultavam a resolução das situações problemáticas - Relatos das profissionais e famílias 
Percebemos que tanto para as profissionais de educação como para as famílias a ocorrência e a resolução de situações problemáticas eram atravessadas, influenciadas por características do município, do campo, da Escola e das famílias rurais. No entanto, notamos que para as profissionais as (negativas) características atribuídas às famílias (ligadas à sua dinâmica e práticas de educação junto à criança) e às crianças (dificuldades nas interações e realização de tarefas) parecem ter preponderância na ocorrência e dificuldade de resolução de tais situações, ainda que as profissionais tenham indicado que características do município (ausência de transporte escolar para os pais), do campo (distância geográfica) e da Escola (dinâmica e estrutura física) também contribuíam nestas circunstâncias. Já para as famílias parece que diversos elementos estariam envolvidos na ocorrência e resolução das situações problemáticas. Não notamos, nas falas das famílias, a referência destacada a um único elemento que estaria envolvido nessas situações.

Ao observamos as significações das profissionais e das famílias, percebemos ainda que as mesmas ora se afastaram e ora se aproximaram, conforme apresentado nas figuras a seguir:

\begin{tabular}{|l|}
\hline Significações aproximaram-se \\
\hline - A aproximação das significações das profissionais em relação às significações das famílias \\
ocorreu em momentos que afirmaram que contribuíam para a ocorrência de situações \\
problemáticas e dificultavam sua resolução: as dificuldades da criança na relação com \\
colegas e professora, bem como na realização de atividades escolares; a organização da \\
dinâmica da Escola que possibilitava crianças ficarem sozinhas sem a supervisão de um \\
adulto; a estrutura inadequada da instituição escolar para crianças da Educação Infantil; e a \\
distância geográfica entre a Escola e famílias associada à ausência do transporte escolar, e \\
que dificultava a ida dos pais ao âmbito escolar. Nesses momentos, percebemos que os \\
elementos indicados por pais e profissionais se relacionavam com características das crianças \\
atendidas e do contexto rural e escolar nos quais estavam inseridas.
\end{tabular}




\section{Significações distanciaram-se}

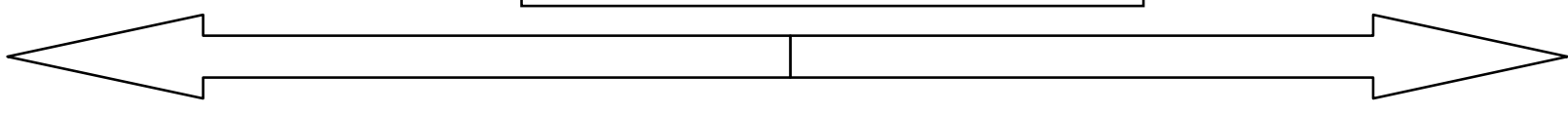

- O distanciamento das significações das profissionais em relação às significações das famílias pareceu se relacionar principalmente com momentos em que as profissionais, para justificar a ocorrência e dificuldades de resolução das situações problemáticas, recorreram às concepções defendidas socialmente sobre as famílias pobres e rurais, enquanto as famílias mencionaram que diversos elementos estariam envolvidos nestas circunstâncias, estando os mesmos relacionados às famílias, à Escola, ao campo e ao município. Enquanto as profissionais se aliaram com frequência às concepções (negativas) presentes na matriz sócio-histórica sobre famílias populares e rurais, as famílias pareceram se apoiar em condições concretas de vida e de trabalho no campo e de atendimento na Escola da criança e dos pais para justificar a ocorrência e os obstáculos para resolução das situações problemáticas. 


\section{CAPÍTULO}

6

\section{Discussão}

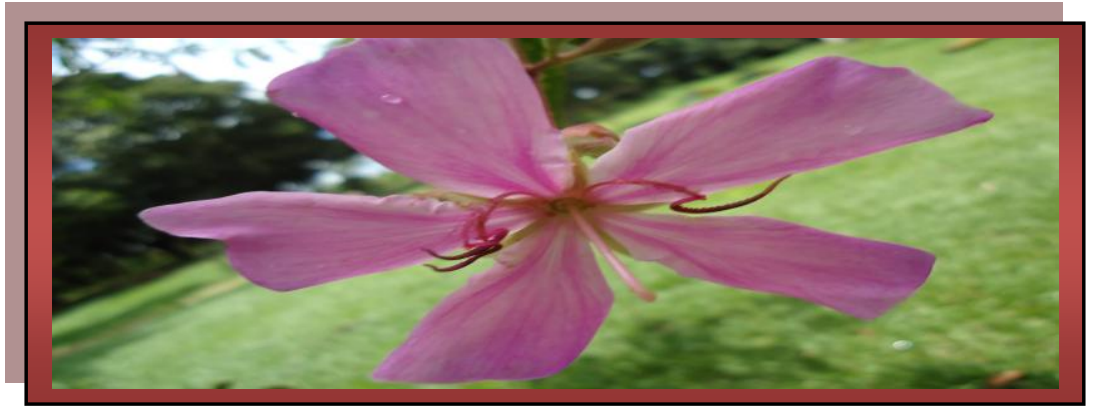





\section{DISCUSSÃO}

Ao partirmos da hipótese de que as significações que compõem o universo semiótico das profissionais da educação e das famílias do campo partilham elementos da matriz sóciohistórica e procurarmos investigar suas aproximações e distanciamentos, situamo-nos no mesmo campo de interesse de pesquisas que vêm apontando a complementaridade entre família e instituição como ponto fundamental no atendimento à criança de 0 a 6 anos, em espaços coletivos, e por esse motivo necessário de ser compreendido. Entender esse processo permite construir conhecimento que contribua para a melhoria da qualidade do que é ofertado para os bebês e crianças pequenas nesses espaços, numa perspectiva que tem a integralidade da criança como referência para o trabalho educativo.

Se esse tema é necessário de investigação em contextos urbanos, para nós, ele assume um caráter de urgência, quando pensamos as instituições de educação no campo dado o duplo silenciamento a que vem sendo submetidas as crianças de zero a seis anos residentes em áreas rurais, seja pela questão etária, seja pela vinculação com o rural (SILVA, PASUCH, SILVA; 2012). O que querem as famílias do campo na relação com a Pré-escola e o que a Escola pensa sobre as famílias do campo são questões cujas respostas ainda carecem de ser construídas com acúmulo de pesquisas na área. $\mathrm{O}$ trabalho procurou, assim, dar visibilidade a este tema, esmiuçando elementos da relação família e instituição de Educação Infantil no contexto rural. Contudo, partiu ele também de elementos adicionais em sua hipótese, apostando que a relação diferenciada no e com o rural e suas condições materiais de existência poderiam circunscrever diferentes significações sobre a relação da Educação Infantil e famílias do campo, marcadas por movimentos de proximidade e distanciamento. Ao longo da pesquisa, foi possível esmiuçar alguns desses elementos, agora apresentados numa síntese que procura evidenciar os movimentos de (des)encontros entre as famílias e as instituições do campo e a rede de significações implicada nas aproximações e distanciamentos de suas significações.

\subsection{Movimentos de (des)encontros entre a Educação Infantil e a família do campo}

Em relação à demanda por vagas, problemática bastante discutida na Educação Infantil em áreas urbanas, profissionais da Escola investigada indicaram a existência de demanda para a Educação Infantil no campo para crianças de 5 anos, ocorrendo, entretanto, menos 
solicitações de vagas para crianças de 0 a 4 anos, que inclusive não eram avaliadas por profissionais como demanda. Chamamos esta demanda de "silenciada", ou seja, que é manifestada pelas famílias na instituição escolar, mas que não é vista e registrada como demanda por Educação Infantil. Já as famílias do campo afirmaram que existia na comunidade demanda de pais por vagas em Creche e Pré-escola para suas crianças de 0 a 5 anos.

Evidenciamos que tanto profissionais como as famílias defenderam a necessidade de haver Pré-escola no campo. No entanto, no que tange à Creche, houve divergências. Enquanto as famílias indicaram a necessidade de haver Creche na zona rural, houve profissionais que se aliaram a esta fala das famílias, mas outras afirmaram a não necessidade de sua existência nesse contexto.

Nessa discussão sobre demanda e necessidade por Educação Infantil no contexto rural, percebemos, assim, que houve diferenciações em relação à questão etária, especialmente quando está em pauta a criança de 0 a 3 anos. Tal fato também é evidenciado no contexto urbano. Segundo Laviola (2010), diversas pesquisas têm indicado que o cuidado e educação dos bebês têm sido vinculados ao espaço privado, o que pode interferir na escolha e demanda das populações citadinas por instituições de Educação Infantil, sendo maior a procura pela Pré-escola. A escolha e a demanda pela Creche nas cidades aparecem relacionadas, muitas vezes, à necessidade de as famílias trabalharem, à distância entre o trabalho e o local de moradia e à impossibilidade de ficarem exclusivamente com seus filhos ou de conciliarem o trabalho e a educação das crianças pequenas. No estudo realizado por Madlum (2012), em um contexto rural de assentamento, esta problemática da diferenciação etária na escolha das famílias pela modalidade de atendimento em Creche também foi verificada. Os moradores investigados no assentamento, que não possui instituição de Educação Infantil, ao mesmo tempo em que defendem a importância da Pré-escola, evidenciam uma concepção de que o ambiente familiar é o local ideal para a criança pequena. Eles utilizam alguns marcadores de desenvolvimento como indicadores para a colocação da criança na Creche, dentre eles, a aquisição da fala e da marcha. Entretanto, quando questionados sobre a necessidade das famílias e quando para eles é apresentada a possibilidade da existência de Creche no próprio assentamento, as visões se modificam, e, nestes casos, indicam a necessidade de Creche para as populações moradoras em territórios rurais, necessidade esta vinculada à presença da mulher na atividade produtiva do assentamento e à luta pela igualdade de oportunidades de trabalho entre homens e mulheres. No rural investigado no presente estudo, notamos que as concepções sobre o cuidado e a educação da criança pequena parecem contribuir para a 
existência de uma menor demanda pela Creche em relação à Pré-escola, sendo o compartilhamento das práticas junto à criança entre pais e Educação Infantil defendido como ideal predominantemente no caso da Pré-escola. Porém características das famílias do campo foram citadas pelas genitoras como importantes elementos que colocam a Creche como instituição que deve existir no contexto rural. $O$ fato de muitas famílias terem as agroindústrias como locais de trabalho e não estarem voltadas à agricultura familiar torna não só a Pré-escola, mas também a Creche como necessária e solicitada naquela comunidade ou para aquelas famílias que possuem uma inserção produtiva não mais dependente do trabalho na própria terra. Percebemos, nesse cenário, o quanto características do contexto rural investigado, mais especificamente suas condições de trabalho e relações econômicas, influenciam as significações das famílias do campo referentes à Educação Infantil.

O material levantado junto as participantes desta pesquisa inclinou assim nosso olhar e nossos questionamentos para as possíveis especificidades e diferenciações da categoria ampla "rural" e para as possibilidades de continuidades ou não que cada particularidade dela possui em relação aos modos de viver e de produzir, característicos de contextos urbanos. O critério de diversidade de famílias, do ponto de vista de sua vinculação econômica e produtiva ou não com a terra, não se mostrou um elemento presente ou que indicasse diferenciadas formas de a Escola olhar para estas famílias, vistas também como famílias rurais a partir de uma matriz única de rural, às vezes idealizado e às vezes inferiorizado. Assentados, por exemplo, foram diferenciados pelas profissionais da Escola muito mais em relação à questão identitária vinculada ao movimento social do que necessariamente à forma de vida e produção econômica da família. As formas de tratamento da família pela Escola, ao longo deste trabalho, mostraram poucas diferenciações para as composições e tipos de organização econômica das famílias. Neste emaranhado de significações, a demanda é vista ora como vinculada também a imagens e representações de campo abstratas (em especial no caso da Escola), ora a elementos pautados na concretude daquele campo e famílias investigadas (como no caso das famílias que, mesmo não querendo para elas a Creche, apontavam-na como uma necessidade de outras famílias). A compreensão de aspectos da demanda das famílias do campo parece-nos, portanto, exigir um esforço adicional no sentido de nos desdobrarmos do imaginário de família urbana, mas também e necessariamente, de nos desdobrarmos do imaginário de família rural como sendo única. A investigação sobre a relação família e Escola, no caso do contexto rural, parece necessitar de um movimento que exige olhar para os aspectos gerais desta relação, presentes na cidade e no campo, mas também para aspectos específicos de cada um desses contextos. Ao mesmo tempo, também, 
parece ser necessário olhar para aspectos gerais e específicos que marcam e atravessam os diferentes rurais investigados que configuram diferentes condições de vida das famílias. A exigência de compreender o rural revela-se, portanto, como um resultado da pesquisa e como uma necessidade para pesquisadores e profissionais que se arriscam na Educação Infantil em área rural, em particular quando o foco é a relação instituição de Educação Infantil e família. As famílias do campo investigadas na pesquisa são atravessadas por elementos que compõem as possibilidades de viver naquele campo, marcando os modos de produção de suas vidas, as possibilidades de emprego e renda, a distribuição e consumo da produção, a mobilidade no campo.

Segundo Arruda e Brito (2009), muitos campos brasileiros são hoje o que denominam de "campos modernos", dominados pela ação das agroindústrias e que trazem condições de vida para as populações do campo similares à dos trabalhadores pobres e moradores nas cidades. O rural por nós investigado talvez seja possível de ser caracterizado nesta direção.

Consideramos que tais condições de vida e de trabalho nos territórios rurais podem contribuir para a existência de pontos de encontro entre as demandas encontradas nas cidades, como pelas Creches e Pré-escolas em tempo integral. Por outro lado, é sabido que existem comunidades que ainda mantêm formas de organização coletivas e/ou tradicionais, o que podem trazer novas maneiras de organização do trabalho, de dinâmicas familiares e de relação das famílias com a Creche e Pré-escola. A diversidade, a concretude e as especificidades das condições de vida das famílias rurais emergem, dessa forma, como importantes elementos que devem ser considerados pela Escola e pelas políticas públicas para a discussão de demanda e oferecimento da Educação Infantil no campo e da relação família e Escola, junto com a compreensão dos elementos gerais que atravessam esses diferentes campos.

No que se refere aos objetivos da Educação Infantil, algumas profissionais participantes desta pesquisa afirmaram que tal modalidade de educação teria como finalidade complementar a família na educação da criança; outras profissionais defenderam que não cabe à Educação Infantil educar a criança; outras indicaram ainda a instituição escolar como sendo substitutiva das práticas maternas. Já as famílias do campo se aliaram à concepção de que a Educação Infantil complementa a família na tarefa de cuidar e educar a criança. Ainda na discussão sobre as finalidades da Educação Infantil, profissionais e famílias afirmaram que tais instituições teriam como meta diversificar as interações entre as crianças e promover processos de aprendizagem e de desenvolvimento, preparando-as para o Ensino Fundamental. A alfabetização foi, em alguns momentos, indicada por profissionais e famílias como sendo objetivo da Educação Infantil, mas em outros momentos tal meta não foi atribuída às Creches 
e Pré-escolas. A Educação Infantil foi defendida, ainda, pelas profissionais e famílias como forma de ascensão social das populações pobres e rurais e também como meio de promover a igualdade de oportunidades entre as populações do campo e as citadinas. As zonas de significações relacionadas aos objetivos da Educação Infantil transitam assim no diálogo com os discursos e práticas construídos historicamente na consolidação da Educação Infantil enquanto parte do sistema de ensino, com função própria e diferenciada da família, e por isto mesmo, a ela complementar.

A relação com as populações pobres e com as dificuldades de melhoria nas condições de trabalho e de vida no campo também foram elementos concretos deste contexto que influenciaram as significações das profissionais e famílias sobre as finalidades da Educação Infantil no campo. Apesar destas características do território rural estarem presentes em alguns momentos na discussão dos objetivos da Educação Infantil no campo, percebemos que o diálogo com a realidade deste contexto não se constituiu como algo norteador e fundante para as participantes refletirem sobre o papel da instituição escolar como Escola rural. $\mathrm{Na}$ pesquisa de Faria (2007), realizada em uma Escola de Ensino Fundamental e de Educação Infantil localizada em um assentamento em Minas Gerais, cujos professores e famílias eram vinculados a um movimento social de luta pela terra, a investigadora evidenciou que havia a defesa, pela comunidade escolar, de que a Escola realizasse um trabalho interligado à Educação do campo e à realidade do Movimento. Naquele contexto, havia uma circulação de discursos referentes ao paradigma da Educação do campo, diferentemente do encontrado na nossa pesquisa.

$\mathrm{Na}$ nossa pesquisa, ainda que profissionais tenham indicado a importância da Escola estar atrelada à realidade das famílias do campo e de as famílias darem indicações em suas falas desta relevância, não percebemos uma defesa aprofundada de princípios de uma Educação organicamente vinculada àquelas famílias e aos seus modos de inserção no campo, embora haja uma aproximação aos princípios gerais e nacionais da Educação Infantil. Constatamos que há, no contexto estudado, movimentos de incorporação dos princípios do marco legal atual sobre a Educação das populações do campo, mas não ficou evidente sua apropriação conforme almejado nas legislações e publicações da área (BRASIL, 2002, 2008).

Esses elementos e significações que revelam a forma como as famílias e as profissionais concebem a Educação Infantil no campo, constroem suas expectativas em relação a esta modalidade de educação e se apropriam de seus princípios, revelam também indícios de que há neles influências pelas vivências diferenciadas no contexto no qual se encontram. Uma das hipóteses que podemos levantar sobre as significações das famílias 
pesquisadas estarem distantes dos debates acerca do marco legal da Educação das populações do campo é o fato de as mesmas estarem envolvidas com o trabalho nas agroindústrias, e não estarem, por exemplo, ligadas a movimentos sociais e sindicais do campo, protagonistas na disputa por uma educação vinculada à realidade dos sujeitos do campo, como ocorria no contexto investigado por Faria (2007) citado acima. No que tange às profissionais, que também não eram vinculadas a movimentos sociais e sindicais do campo e que moravam na cidade, questionamos-nos em que medida as mesmas participaram e/ou participavam de discussões sobre a Educação nos territórios rurais, suas especificidades e suas relações de continuidade com a educação urbana, em seus Cursos de graduação e de formação continuada. A nossa pesquisa parece evidenciar que o conhecimento e debate sobre os princípios da Educação das populações do campo conjuntamente com os da Educação Infantil compõem o conjunto de elementos necessários para que as relações com as famílias rurais estejam pautadas em suas condições concretas de vida.

Na relação da Educação Infantil e família, diferentes instrumentos foram apontados, alguns tradicionais, outros criados na concretude daquele contexto. Dentre os primeiros, destacamos: reuniões; festas e eventos; bilhetes; telefone; ida das famílias por solicitação da Escola e por iniciativa das mesmas. O uso do motorista do transporte escolar e da própria criança como mediadora da relação Escola e família despontou como importantes instrumentos desta relação no campo investigado e que não foram descritos em outros estudos (BHERING; NEZ, 2002; MEIRA, 2004; CÔRREA, 2006; SAISI, 2010). Sobre o uso dos diferentes instrumentos na relação Escola e família, notamos que profissionais pareceram dar mais destaque para as reuniões enquanto as famílias enfatizaram a ida dos pais em momentos não organizados pela Escola. Notamos que esta ida estava dependente, geralmente, de condições de transporte, como por exemplo, carona, tendo a família poucas possibilidades de estar na instituição em horários determinados e previamente estipulados, seja pela Escola, seja pela própria família. Nesse cenário, por vezes os participantes criam novos instrumentos de comunicação para tentar superar essas condições.

Tanto para profissionais como para famílias, os instrumentos da relação citados acima teriam finalidades relacionadas aos aspectos de gestão/atendimento da Escola e relativos à criança, mais especificamente à sua matrícula, desempenho e comportamento na instituição escolar. Para as profissionais, tais instrumentos possibilitariam ainda viabilizar a discussão do orçamento escolar, a comunicação sobre acidente da criança na Escola e a escuta das opiniões das famílias sobre o atendimento. Notamos que, para as famílias, o uso dos instrumentos teria outras finalidades que se relacionavam com a intenção dos pais em conhecer a Escola e o 
cotidiano do filho na mesma e compartilhar o cuidado e educação da criança com a instituição escolar. Tais tentativas de compartilhamento parecem não ser claramente constatadas pela Escola, ainda que profissionais da instituição escolar busquem, segundo relatos das profissionais e famílias, ouvir e atender solicitações dos pais relativas ao cuidado e à educação da criança.

Para profissionais e famílias, um elemento importante e que facilitava o uso de instrumentos na relação Escola e família e o encontro entre pais e profissionais, era o fato de a Escola se colocar aberta à família e mobilizada na busca por encontrar e conversar com as famílias atendidas. Notamos que as profissionais, em alguns momentos, recorreram à questão da distância geográfica associada à falta do transporte e formato das atividades realizadas na Escola junto às famílias, para explicar a não ida da maioria dos pais ao contexto escolar. No entanto, em outros relatos, as profissionais pareceram se aproximar da concepção de que a ausência dos pais na Escola se daria devido à distância geográfica associada ao fato de as famílias nem sempre estarem interessadas em comparecer à instituição escolar.

Já as famílias, em suas falas, indicaram a distância geográfica como sendo um importante elemento que influenciava a ida à Escola. Tendo em vista a grande distância física entre as instituições escolar e familiar, genitoras afirmaram que a falta de transporte escolar para os pais, a ausência de transporte das famílias (devido às suas condições econômicas) e, no caso de famílias que possuíam veículo, a não possibilidade de utilização deste pelas genitoras contribuíam para dificultar o comparecimento das mesmas à Escola. Apesar de tais obstáculos, genitoras afirmaram utilizar, quando possível, formas alternativas para comparecer à instituição e afirmaram que suas idas à Escola seriam frequentes, demonstrando mobilização para irem à mesma em momentos que tinham as condições necessárias. Famílias indicaram, porém, o desejo de participar mais da Escola e queixaram-se que a relação da Escola com os pais ficava restrita à solução de problemáticas. Partindo da concepção de que a grande distância geográfica entre Escola e as residências das famílias contribuía para dificultar a relação entre as instituições familiar e escolar, a disponibilização do transporte escolar para as famílias irem à Escola despontou como sendo uma reivindicação de profissionais e familiares da Escola investigada.

Percebemos, dessa forma, a existência de diferenças nas formas como profissionais e famílias viam e vivenciavam seus momentos de encontros, bem como sobre o que esperavam e desejavam dos mesmos. Dificuldades na relação Escola e família também foram indicadas pelas participantes do estudo em situações problemáticas, sendo as mesmas: ingresso da 
criança na Escola; queixas sobre frequência e aprendizagem da criança; queixas sobre o comportamento da criança na Escola; acidentes envolvendo a criança no âmbito escolar.

Ao analisarmos os dados referentes às situações problemáticas, constatamos que, nesses momentos, a relação Escola e família parecia ser vista pelas famílias como sendo ora de apoio, ora de confronto, ora de autoridade da Escola em relação à família e ora de silenciamento. Já as profissionais pareciam ver tal relação como sendo ora conflitiva e ora distanciada, atribuindo tal distanciamento principalmente a um desinteresse e desestrutura das famílias pobres e rurais. Evidenciamos, ainda, que parecia haver, nessas circunstâncias, instrumentos ineficazes na relação Escola e família. Tal fato fazia com que famílias e profissionais recorressem a mediadores externos para solucionar situações difíceis vivenciadas no âmbito escolar.

Tanto para as profissionais de educação como para as famílias, a ocorrência e a resolução de situações problemáticas eram atravessadas, influenciadas por características do município, do campo, da Escola e das famílias rurais. No entanto, como constatado em outros estudos (MEIRA, 2004), parecia haver uma tendência de a Escola atribuir à criança a origem e à família a solução das situações problemáticas. A intervenção junto à criança (e não na relação Escola e família) parecia ser vista por profissionais como principal forma de resolução das situações difíceis vivenciadas. Houve, porém, episódios em que visualizamos a existência de ações de compartilhamento entre Escola e família, sendo os mesmos relativos a uma situação de acidente da criança na Escola. Esses episódios evidenciam que há situações em que a Escola e a família da criança se unem e dialogam para resolver a problemática.

A partir das discussões realizadas acima, notamos que a relação entre a Escola investigada e as famílias do campo constitui-se por momentos de aproximações e distanciamentos. No entanto, vemos agora esta formulação recheada de elementos concretos de uma situação que é singular, mas ao mesmo tempo guarda elementos de semelhanças com diversos outros contextos investigados em pesquisas nacionais. Além disso, as distâncias parecem predominar e caracterizar tal relação, sendo as mesmas de natureza física (geográfica), interacional (interações pessoais) e semiótica (significações). Tais distâncias parecem contribuir para a existência de dissonâncias na relação Escola e família do campo, diferenciando-se de outros estudos realizados em outros contextos rurais (VARGAS, 2003; POJO, 2003; FARIA, 2007; MARTINS, 2009).

Distâncias, conflitos e tensões na relação Escola e família também ocorrem em instituições urbanas, conforme apontam diversos estudos (HADDAD, 1987; VITORIA, 1997, 1999; BHERING; NEZ, 2002; MEIRA, 2004; CORREA, 2006; FORTKAMP, 2008). No 
entanto, notamos, nesta investigação, que existem características e especificidades do rural que qualificam e configuram tais desencontros, tensões e conflitos. A distância geográfica entre Escola e família; as dificuldades de comunicação via telefone rural; o isolamento de famílias em indústrias; o fato de as famílias não irem à Escola cotidianamente e de não terem condições financeiras para estarem presentes na Escola; a ausência do transporte escolar são alguns dos marcadores importantes e que trazem diferentes condições e formas de pais e profissionais significarem e viverem a relação Escola e família, suas possibilidades e dificuldades naquele contexto rural.

Com a pesquisa, fica evidente como as concretudes do campo e das condições de vida e de trabalho das famílias colocam-se entre as instituições familiar e escolar, mediando também esta relação, dificultando, muitas vezes, o uso de instrumentos de diálogo e de comunicação e, portanto, influenciando a quantidade e a qualidade da relação entre as mesmas. O fato de a Escola e família serem longe dificulta o encontro entre pais e profissionais, o fato de as famílias não terem condições econômicas de transporte e não haver uma política para isto dificulta a superação da grande distância geográfica no campo, o fato de as famílias cumprirem horários de trabalhos fixos nas empresas da agroindústria não permite que compareçam à Escola quando desejam ou nos horários marcados, o fato do telefone rural não funcionar adequadamente dificulta a conversa entre Escola e família, dentre outros elementos. Somam-se a esses elementos outros de natureza semiótica, tais como as significações negativas das famílias pobres e rurais, já mencionados anteriormente.Tais discussões nos levam a pensar que as características e especificidades do campo e as condições de vida e de trabalho de suas famílias devem ser colocadas em patamar devido pela Escola, comunidades e poder público no debate sobre como aperfeiçoar a relação Escola e família nos contextos rurais. Defendemos a ideia de que tais elementos devem ser considerados nos debates sobre a relação Escola e família e que primem pela participação dos pais no âmbito escolar. Segundo diversos autores, é necessário que a família ocupe a Escola, ou seja, se sinta e faça parte dela e auxilie no seu cotidiano e ações, que devem estar ancorados em projetos de ser humano e de sociedade e aliados a luta por uma Educação voltada às populações do campo e suas realidades (MOLINA, 2002; CALDART, 2004; ARROYO, 2007; VENDRAMINI, 2007; MARTINS, 2009). 


\subsection{A Rede de Significações: aproximações e distanciamentos das significações das profissionais e famílias sobre a relação Escola e família no campo}

A partir da análise dos dados construídos ao longo da pesquisa, confirmamos a nossa tese. Constatamos que as significações das profissionais e das famílias ora se aproximaram e ora se distanciaram, ao discutirem a temática do trabalho. Tais movimentos de aproximações e distanciamentos pareceram ocorrer, tendo em vista que as participantes, ainda que compartilhem elementos comuns da matriz sócio-histórica, possuem uma relação diferenciada com o contexto rural no qual a Escola se localizava. Evidenciamos que a relação diferenciada com o rural ocorria tendo em vista diferentes elementos, dentre eles o local de moradia das participantes e as experiências e contato que mantinham com a concretude do campo. Enquanto as famílias residiam no campo e vivenciavam sua realidade, as profissionais residiam na cidade e, ainda, no cotidiano escolar possuíam poucas possibilidades de diálogo e troca de saberes com as famílias sobre aspectos do campo, havendo poucos instrumentos que contribuíssem para a construção de conhecimentos pela Escola sobre aquele rural, e pela família sobre aquela Escola. A experiência direta, pela ida de profissionais às residências das famílias ou em outros locais da comunidade, não apareceu como sendo um instrumento utilizado na relação família e Escola, para a ampliação de saberes das profissionais sobre o campo e suas famílias. As experiências diferenciadas com o contexto rural no qual se situava a Escola permearam a construção de significações das profissionais e famílias sobre a relação entre as instituições escolar e familiar, o que nos remete à discussão e consideração das significações como sendo contextuais, encarnadas em uma determinada configuração da realidade.

As diferenças e semelhanças nas significações das profissionais de educação e famílias do campo nos indicam a existência de elementos distintos, mas também comuns nas redes de significações das profissionais e famílias presentes na discussão da relação Escola e família (sobre demanda, objetivos, instrumentos da relação, distância geográfica e situações problemáticas). Na figura a seguir, buscamos apresentar tais elementos das redes de significações das participantes da pesquisa. No centro da figura, representamos os elementos comuns das redes de significações das profissionais e das famílias. À direita da figura, representamos os elementos específicos das redes de significações das famílias. E à esquerda representamos os elementos específicos das redes de significações das profissionais. 


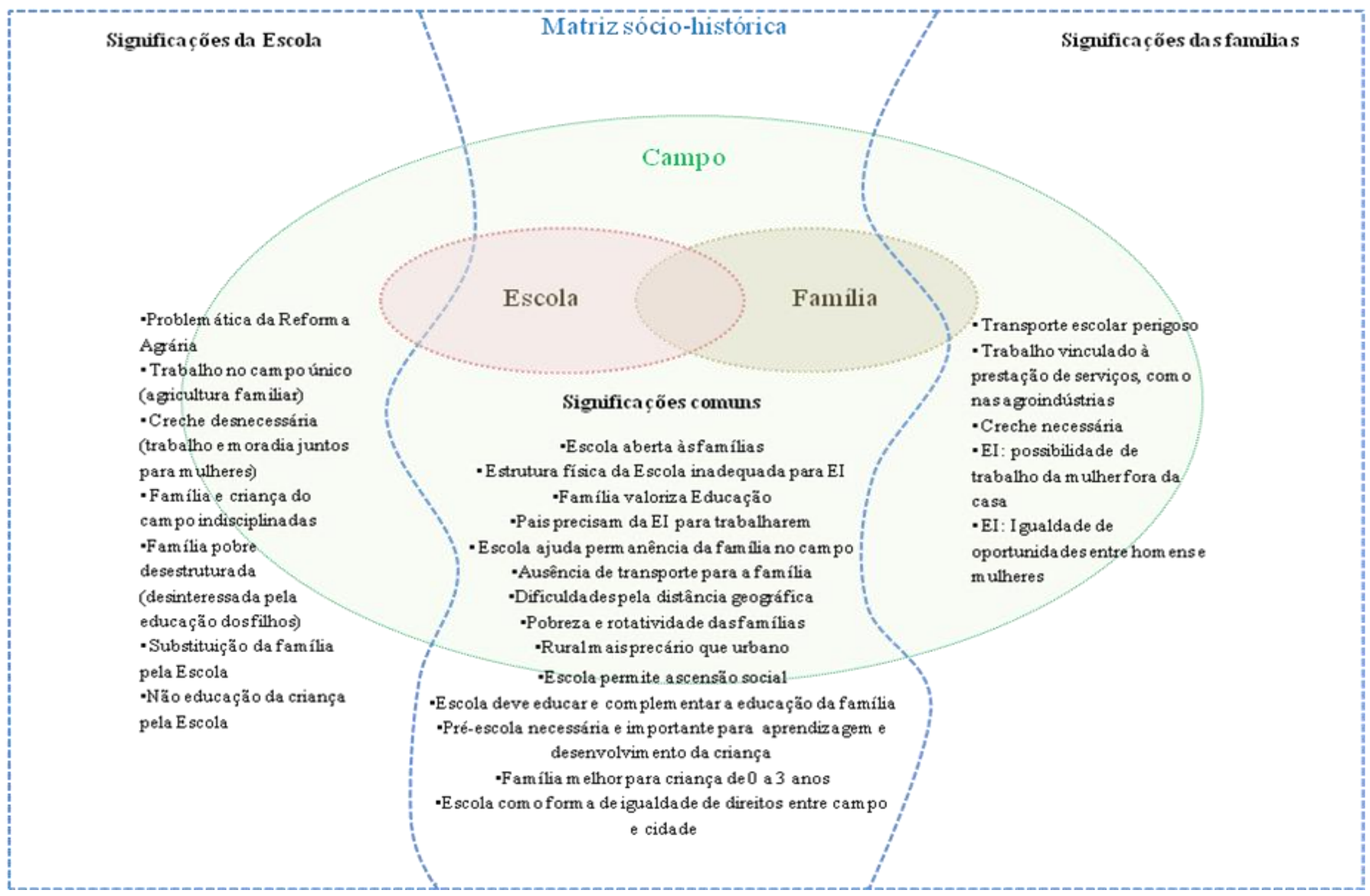

Figura- Rede de significações das profissionais e famílias 
A rede esquematizada evidencia que os distanciamentos das significações das participantes na discussão da relação Escola e família ocorreram quando as profissionais dialogaram com concepções negativas sobre a atuação das famílias junto à criança e com concepções sobre o papel da Escola, presentes na matriz sócio-histórica. Tais distanciamentos ocorreram ainda quando as profissionais dialogam com elementos imaginados e gerais sobre o campo e menos pautados na realidade e concretude daquele campo, citados pelas famílias e relativos: ao tipo de trabalho no campo; às condições de trabalho e de vida naquele rural e que repercutiam na demanda e necessidade de Creche; à dinâmica das famílias do campo na qual estavam presentes o interesse e a mobilização pela Educação de seus filhos; à ausência de Educação Infantil naquele campo e suas consequências para as famílias, como a desigualdade de oportunidades em relação ao gênero; à rotatividade e mobilidade das famílias naquele campo; ao trabalho marcado pela presença da agroindústria.

Já os movimentos de aproximações das significações das participantes ocorreram em momentos que profissionais e famílias dialogaram com elementos concretos da realidade da Escola e do campo referentes: à estrutura e dinâmica da Escola para as crianças da Educação Infantil; às práticas da Escola junto à família, como sua abertura para os pais; às condições de atendimento da Escola no que tange ao transporte da família; ao papel da Escola para a permanência da família no campo; à dinâmica familiar (na qual estão presentes o interesse pela Educação dos filhos; a necessidade de Educação Infantil para os genitores trabalharem, tendo em vista suas condições de vida e econômicas; a falta de recursos financeiros e mobilidade em busca de melhores condições de trabalho e de vida; a dificuldade de locomoção no campo, diante da falta de veículo próprio). As experiências e conhecimentos, construídos pelas profissionais sobre o campo no qual se situava a Escola investigada e das famílias sobre a Escola, emergiram como aspectos relevantes e que contribuíram para que houvesse tais aproximações.

As aproximações das significações das participantes ocorreram ainda em momentos que dialogaram com elementos da matriz sócio-histórica e relativos: aos objetivos da Escola para a criança e família do campo, tendo em vista suas condições de vida e de trabalho em relação às da cidade; ao papel da família no que tange à criança de 0 a 3 anos.

Entendemos que o fato de as significações das profissionais e dos pais sobre a relação Escola e família se distanciarem não significa, a priori, que contribuiria para a promoção de uma relação inadequada entre Escola e famílias. O contrário também seria válido, ou seja, o fato de as significações das profissionais e famílias sobre a relação Escola e família se aproximarem não significa, a priori, que contribuiria para a promoção de uma relação 
adequada entre Escola e família. No estudo de Bhering e Nez (2002), por exemplo, tanto os profissionais como as famílias aliavam-se à concepção da Educação Infantil como sendo uma instituição assistencial, ou seja, suas concepções sobre a Educação Infantil se aproximavam. Porém, tais concepções não contribuíam para a promoção de uma relação, entre a Educação Infantil e os pais, de complementaridade da educação da criança. Outros estudos já constataram que profissionais e famílias defendiam concepções diferentes sobre os objetivos da Educação Infantil, o que é indicado como estando relacionado ao surgimento de conflitos e distanciamentos entre pais e profissionais e que prejudicavam o processo de compartilhamento do cuidado e educação da criança (MEIRA, 2004).

A análise dos dados indicou que as significações das profissionais de educação e famílias se aproximaram mais frequentemente quando discutiram questões relativas aos objetivos da Educação Infantil para as crianças/famílias no campo. Para este debate, as entrevistadas dialogaram com elementos da matriz sócio-histórica, mas também com elementos dos contextos investigados. Na discussão da (não)demanda por Educação Infantil pelas famílias do campo, dos instrumentos da relação entre a Escola e as famílias, das distâncias geográficas e das situações problemáticas na relação entre a Escola e as famílias do campo, observamos que as significações se distanciaram mais frequentemente. Tais distanciamentos pareceram ocorrer, conforme já discutido anteriormente, principalmente nos momentos em que as profissionais se afastaram das características e especificidades do meio rural e se vincularam a concepções genéricas sobre ele. A ausência de conhecimentos mais aprofundados sobre condições de vida e de trabalho, dinâmicas, concepções, desejos e expectativas das famílias pareceu favorecer a defesa, pelas profissionais, de significações gerais presentes na matriz sócio-histórica e que não refletem necessariamente a concretude e a realidade das famílias do campo e de sua relação com a Escola. A defesa pelas profissionais, por exemplo, de concepções das famílias pobres e rurais como sendo desinteressadas pelos filhos e pela Escola pareceu influir consistentemente na construção de significações sobre assuntos abordados (instrumentos da relação entre a Escola Flamboyant e as famílias do campo, distâncias geográficas e situações problemáticas na relação entre a Escola e família) e que se afastaram das concepções das famílias do campo sobre tais temáticas.

De toda forma, é importante assinalar que as aproximações e distanciamentos ocorrem também dependentes dos papéis de cada um no processo de educação compartilhada da criança. Profissionais de educação e familiares falam de lugares distintos e possuem pontos de vista semelhantes, mas também diferentes. O que nos interessou foi explicitar essas diferenças, compor as suas redes, compreender o que provoca os movimentos de aproximação 
e distanciamento, suas determinações concretas e simbólicas, construindo assim uma metodologia de explicitação desses elementos que permita que, com a visibilidade por ela construída, tanto Escolas como famílias possam melhor entender seus papéis e o papel do outro, identificar que eles atuam em relações de complementaridade. Este entendimento requer o reconhecimento de que a relação família e Escola inclui compartilhamento de significações, de expectativas e de desejos, mas também a existência de competição, de situações de conflitos que são constitutivas desta relação e, por isto mesmo, precisam ser visibilizadas e trabalhadas pela comunidade escolar. 


\section{CAPÍTULO}

\section{Considerações Finais}

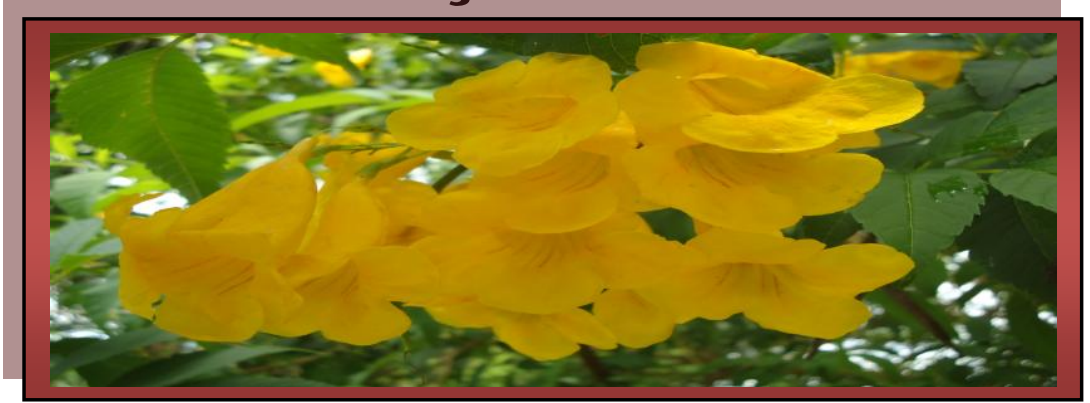





\section{Considerações Finais}

A presente investigação evidencia e discute elementos de um campo em particular, de suas famílias e da Escola e, ao indicar suas características, permite problematizar visões homogeneizantes de rural e de relação Escola e família no campo. A relação entre as instituições escolar e familiar no campo mostrou-se constituída por elementos por vezes semelhantes e por vezes distintos dos encontrados no contexto urbano e em outros contextos rurais, o que colocou em evidência a sua complexidade. O estudo indica, portanto, como a relação Escola e família no campo precisa ser compreendida em suas continuidades e similaridades com outros contextos, mas também em suas concretudes e especificidades. $\mathrm{O}$ tipo de contexto rural e suas características geográficas e econômicas, as diversidades das famílias, suas demandas e concepções, as relações de trabalho no campo, as condições de vida ora parecidas e ora distintas das urbanas são elementos evidenciados nesta pesquisa que atravessam a relação Escola e família e emergem como importantes aspectos a serem considerados e compreendidos por profissionais, gestores e instituições que almejam a melhoria da relação entre a Educação Infantil e as famílias do campo.

A partir da realização deste estudo, consideramos que tais características do campo e das famílias, na relação intrínseca com a Educação Infantil, merecem também ser aprofundadas em pesquisas futuras. Entendemos que novos estudos são necessários para: ampliar e dimensionar a demanda por Creche e Pré-escola nos campos brasileiros; evidenciar quais as consequências da ausência de Educação Infantil no campo para as famílias, por exemplo, no que tange às relações de gênero e às formas encontradas de cuidado e educação da criança; investigar se e como a distância geográfica entre Escola e família tem sido um dificultador na relação Escola e família em outros territórios rurais e como as políticas públicas têm lidado com esta questão, por exemplo, por meio do oferecimento ou não do transporte escolar para os pais; compreender as concepções das Escolas sobre as famílias pobres e rurais e como as mesmas se articulam com as formas encontradas de se relacionarem como as famílias; investigar os instrumentos utilizados e criados no contexto rural para estabelecimento da relação entre Escola e pais e como os mesmos contribuem para o compartilhamento do cuidado e da educação da criança entre Creches/Pré-escolas e famílias do campo, dentre outros. Ao discutir a relação Escola e família no meio rural uma questão tangencial a este tema também emergiu como sendo relevante para futuras pesquisas e que se refere à formação de professores. Consideramos importante investigar como os cursos de 
formação de professores têm abordado os princípios da Educação Infantil e o Paradigma da Educação do campo.

Nesta pesquisa, buscamos compreender a relação Escola e família a partir do estudo das significações, entendidas como encarnadas na realidade concreta, e indicamos elementos das redes de significações das participantes. Pensamos ser interessante, ainda, a realização de outros estudos que investiguem as diferentes redes de significações de Escolas e famílias em diferentes rurais brasileiros, procurando evidenciar os elementos singulares e gerais que os compõem. Também estudos comparativos entre as redes de significações de instituições urbanas e rurais soam frutíferos nesta direção. Acreditamos que a compreensão das redes de significações existentes nos campos e nas cidades e de suas (des)continuidades pode trazer elementos para aprofundarmos nossas discussões e conhecimento tanto sobre a Educação Infantil no campo como sobre aspectos da relação família e Escola, como um todo.

A ampliação de conhecimentos sobre os campos, as famílias, as Escolas rurais e, mais especificamente, sobre a relação entre a Educação Infantil e as famílias do campo, urge como necessária no nosso país. Esperamos que a realização de trabalhos na área de Educação Infantil no campo, ainda em crescimento no contexto brasileiro, possa contribuir conjuntamente para a construção de uma Educação Infantil no campo para e com as famílias do campo. 


\section{Referências}

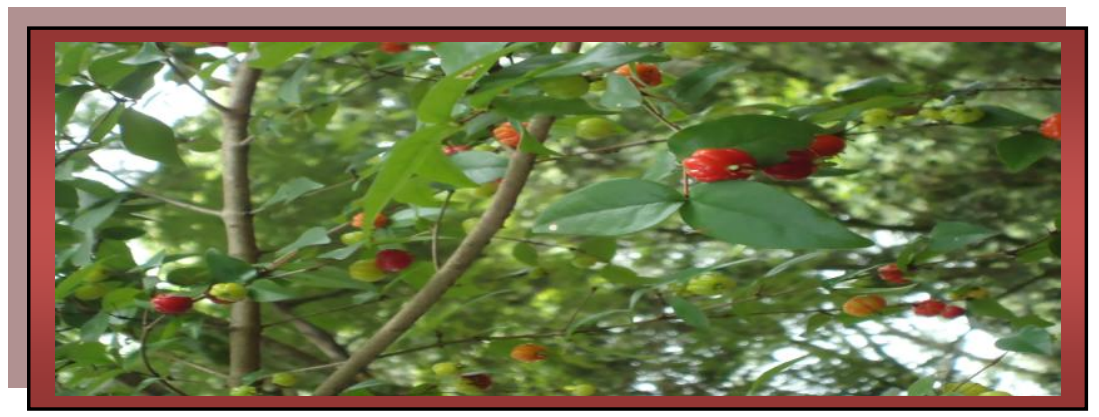





\section{REFERÊNCIAS}

AMORIM, K. S.; VITORIA, T.; ROSSETTI-FERREIRA, M. C. Rede de significações: perspectiva para a análise da inserção de bebês na creche. Cadernos de pesquisa, São Paulo, n.109, p. 115-144, 2000.

ARROYO, M. G. Políticas de formação de educadores(as) do campo. Cadernos Cedes, Campinas, v. 27, n. 72, p. 157-176, 2007.

ARRUDA, E. E.; BRITO, S. H. A. Análise de uma proposta de escola específica para o campo. In: ALVES, G. L. (Org.). Educação no campo: recortes no tempo e no espaço. Campinas: Autores Associados, 2009. p. 23-62.

BAKHTIN, M. Marxismo e filosofia da linguagem: problemas fundamentais do método lógico na ciência da linguagem. São Paulo: Editora Hucitec, 2002.

BERNSTEIN, H. Dinâmicas de classe da mudança agrária. São Paulo: Editora UNESP, 2011.

BHERING, E.; NEZ, T. B. Envolvimento de pais em Creche: possibilidades e dificuldades de parceria. Psicologia: Teoria e Pesquisa, Brasília, v.18, n.1, p. 63-73, 2002.

BRASIL. Constituição (1988). Constituição da República Federativa do Brasil. Brasília, DF: Senado Federal, 1988.

BRASIL. Lei ${ }^{\circ}$ 8.069, de 13 de junho de 1990. Estatuto da criança e do adolescente. Brasília, 1990.

BRASIL. Lei $\mathbf{n}^{\circ}$ 9.394, de 20 de dezembro de 1996. Lei de Diretrizes e Bases da Educação Nacional. Brasília, 1996.

BRASIL. Parecer $n^{\circ}$ 22/98, aprovado em 17 de dezembro de 1998. Diretrizes Curriculares Nacionais para a Educação Infantil. Brasília, DF, 1998.

BRASIL. Ministério da Educação. Diretrizes operacionais para a educação básica nas escolas do campo. Brasília, DF, 2002. 
BRASIL. Ministério da Educação. Secretaria de Educação Infantil e Fundamental. Padrões de Infra-estrutura para as Instituições de Educação Infantil e Parâmetros de Qualidade para a Educação Infantil. Brasília, DF, 2004.

BRASIL. Ministério da Educação. INEP. Pesquisa Nacional da Educação na Reforma Agrária. Brasília, DF, 2005.

BRASIL. Ministério da Educação. INEP. Panorama da educação do campo. Brasília, DF, 2007.

BRASIL. Ministério da Educação. Diretrizes complementares, normas e princípios para o desenvolvimento de políticas públicas de atendimento da Educação Básica do Campo. Brasília, DF, 2008.

BRASIL. Ministério da Educação. INEP. Censo da Educação Básica. Brasília, DF, 2009a.

BRASIL. Ministério da Educação. Diretrizes Curriculares Nacionais para a Educação Infantil. Brasília, DF, 2009b.

BRASIL. Ministério da Educação. Indicadores da qualidade na Educação Infantil. Secretaria da Educação Básica. Brasília, DF, 2009c.

BRASIL. Ministério da Educação. Orientações sobre convênios entre secretarias municipais de educação e instituições comunitárias, confessionais ou filantrópicas sem fins lucrativos para a oferta de educação infantil. Brasília, DF, 2009d.

BRASIL. Parecer no 20/2009 do Conselho Nacional de Educação/Câmara de Educação Básica. Revisão das Diretrizes Curriculares Nacionais para a Educação Infantil. Brasília, DF, 2009e.

BRASIL. Resolução no 5/2009 do Conselho Nacional de Educação/Câmara de Educação Básica. Fixa as Diretrizes Curriculares Nacionais para a Educação Infantil. Brasília, DF, 2009f.

CALDART, R. S. Elementos para a construção do projeto político e pedagógico da Educação do campo. In: MOLINA, M. C. et al. (Org.). Contribuições para a construção de um projeto de Educação do campo. Brasília: Coleção Por uma educação do campo, 2004. p. 1031. 
CALDART, R. S. Educação do campo: notas para uma análise de percurso. Trabalho, educação e saúde, Rio de Janeiro, n. 1, v. 7, p. 35-64, 2009.

CASEY, J. A história da família. São Paulo: Ática, 1992.

CERISARA, A. B.; ROCHA, E. A. C.; SILVA FILHO, J. J. Educação Infantil: uma trajetória de pesquisa e indicações para a avaliação de contextos educativos. In: KISHIMOTO. T. M. et al. (Org.). Formação em contexto: uma estratégia de integração. São Paulo, 2002. p. 203236.

CÔRREA, B. C. Gestão democrática e participação familiar no âmbito da Educação Infantil. Educação: teoria e prática, Rio Claro, v.14, n.26, p. 15-34, 2006.

CRAIDY, C.; KAERCHER, G. E. (Orgs.). Educação infantil: pra que te quero? Porto Alegre: Artmed, 2001.

DARAHEM, G. C.; SILVA, A. P. S.; COSTA, N. R. A. Da Teoria do apego à Rede de Significações: Maria Clotilde Rossetti-Ferreira e a psicologia do desenvolvimento brasileira. São Paulo: Temas em psicologia, v.17, n.1, p.191-207, 2009.

DELGADO, A. C. C. Como as mães de uma creche domiciliar percebem o trabalho de tomar conta de crianças? Rio de Janeiro: Revista Brasileira de Educação, n.28, p. 151-153, 2005.

DICIONÁRIO MICHAELIS. Disponível em: 〈http:// www.michaelis.uol.com.br >. Acesso em: 06 jun. 2012.

DICIONÁRIO ON LINE. Disponível em: <http:// www.dicio.com.br >. Acesso em: 06 jun. 2012.

DICIONÁRIO WIKTIONARY. Disponível em: <http:// www. wiktionary.org >. Acesso em: 06 jun. 2012.

FARIA, A. R. Escola, família e movimento social: um estudo sobre a relação famíliaescola em um assentamento do MST em Minas Gerais. $125 \mathrm{f}$. Dissertação (Mestrado em Educação) - Faculdade de Educação, Universidade Federal de Minas Gerais, Belo Horizonte, 2007. 
FERNANDES, B. M. Os campos da pesquisa em Educação do Campo: espaço e território como categorias essenciais. In: MOLINA, M. C. (Org.). Educação do Campo e Pesquisa: questões para reflexão. Brasília: Ministério do Desenvolvimento Agrário, 2006. p.27-39.

FERNANDES, B. M.; MOLINA, M. C. O campo da educação do campo. In: MOLINA, M. C. et al. (Org.). Contribuições para a construção de um projeto de Educação do Campo. Brasília: Coleção Por Uma Educação do Campo - Articulação Nacional por uma Educação do Campo, 2004.p.53-89.

FERRAZ, L. R. O cotidiano de uma escola rural ribeirinha na Amazônia: práticas e saberes na relação escola e comunidade. 237 f. Tese (Doutorado em Psicologia) - Faculdade de Filosofia, Ciências e Letras de Ribeirão Preto, Universidade de São Paulo, Ribeirão Preto, 2010 .

FIGUEIRAS, C. A. C. A creche comunitária na nebulosa da pobreza. Cadernos de Pesquisa, São Paulo, n.88, p.18-29, 1994.

FORTKAMP, E. H. T. Educação Infantil e família: a complementaridade na perspectiva das famílias de baixa renda. 140f. Dissertação (Mestrado em Educação) - Centro de Ciências da Educação, Universidade Federal de Santa Catarina, Florianópolis, 2008.

GALLO, B. C. Qualidade na Educação Infantil pública: concepções das famílias usuárias. 192 f. Dissertação (Mestrado em Psicologia) - Faculdade de Filosofia, Ciências e Letras de Ribeirão Preto, Universidade de São Paulo, Ribeirão Preto, 2010.

HADDAD, L. A relação Creche-família: relato de uma experiência. Caderno de Pesquisas, São Paulo, n. 60, p.70-78, 1987.

HADDAD, L. Substituir ou compartilhar? O papel das instituições de educação infantil no contexto da sociedade contemporânea. In: MACHADO, M. L. A. (Org.). Encontros e desencontros em educação infantil. São Paulo: Cortez, 2002. p.91-95.

IBGE. Pesquisa Nacional por Amostra de Domicílios 1991/2007. Disponível em: <http://www.ibge.gov.br>. Acesso em: 3 fev. 2012.

IBGE. Pesquisa Nacional por Amostra de Domicílios 2008: primeiras análises. 2009. Disponível em: <http://www.sepm.gov.br/nucleo/dados/09-10-07-comunicapresi-32pnad2008-educacao.pdf >. Acesso em: 21 ago. 2012. 
IBGE. Pesquisa Nacional por Amostra de Domicílios 2009. Disponível em: <http://www.ibge.gov.br>. Acesso em: 3 fev. 2012.

IBGE. Censo 2010. Disponível em: 〈http://www.ibge.gov.br〉. Acesso em: 5 fev. 2011.

KUHLMANN JR., M. Histórias da Educação Infantil brasileira. Revista Brasileira de Educação, Rio de Janeiro, n. 14, p.5-18, 2000.

LAVIOLA, E. C. O bebê, sua educação e cuidado em discursos de mães de camadas médias. 434f. Tese (Doutorado em Psicologia Social) - Pontífica Universidade Católica de São Paulo, São Paulo, 2010.

LIMA, L. P. A Educação Infantil diante da violência doméstica contra a criança: compreendendo sentidos e práticas. 232f. Dissertação (Mestrado em Psicologia) - Faculdade de Filosofia, Ciências e Letras de Ribeirão Preto - Universidade de São Paulo, Ribeirão Preto, 2008.

MADLUM, L. V. Famílias moradoras em assentamento rural: sentidos de creche e escolha dessa modalidade de educação. 115 f. Monografia (Bacharelado em Psicologia) Faculdade de Filosofia, Ciências e Letras de Ribeirão Preto, Universidade de São Paulo, Ribeirão Preto, 2012.

MANCINI, G. U. T. As creches como auxiliadoras das famílias. 1944. Disponível em: <http://www.fcc.org.br/pesquisa/jsp/educacaoInfancia/index.jsp>. Acesso em: 01 out. 2011.

MARQUES, M. I. M. A atualidade do uso do conceito de camponês. Revista NERA, Presidente Prudente, n.12, p.57-67, 2008.

MARTINS, A. P. V. "Vamos criar seu filho": os médicos puericultores e a pedagogia materna no século XX. História, ciências, saúde, Rio de Janeiro, v.15, n.1, p.135-154, 2008.

MARTINS, F. J. Ocupação da Escola: uma categoria em construção. 283 f. Tese (Doutorado em Educação) - Faculdade de Educação, Universidade Federal do Rio Grande do Sul, Porto Alegre, 2009.

MARX, K.; ENGELS, F. A ideologia alemã. São Paulo: Ciências Humanas, 1979. 
MEIRA, M. C. R. Relação Creche família: mito ou realidade. 118f. Dissertação (Mestrado em Enfermagem) - Setor de Ciências da Saúde, Universidade Federal do Paraná, Curitiba, 2004.

MOLINA, M. Desafios para os educadores e educadoras do campo. In: KOLLING, E. J. et al. (Org.). Educação do campo: identidades e políticas públicas. Brasília: Coleção Por uma educação do campo, 2002. p. 26-30.

MORIN, E. Introdução ao pensamento complexo. Lisboa: Instituto Piaget, 1990.

NASCIMENTO, C. G. Agricultores familiares, extrativistas, pescadores artesanais, ribeirinhos, assentados e acampados da Reforma Agrária, quilombolas, caiçaras, indígenas e outros. $301 \mathrm{f}$. Tese (Doutorado em Educação) - Faculdade de Educação, Universidade de Brasília, Brasília, 2009.

NEWMAN, F.; HOLZMAN, L. Lev Vygotsky: Cientista revolucionário. São Paulo: Edições Loyola, 2002.

NOGUEIRA, M. A.; ABREU, R. Famílias populares e escola pública: uma relação dissonante. Educação em Revista, Belo Horizonte, v. 39, p. 41-60, 2004.

NUNES, D. G. Educação Infantil e mundo político. Rev. katálysis, Florianópolis, n. 1, v. 12, p.86-93, 2009.

OLIVEIRA, Z. R. Educação Infantil: fundamentos e métodos. São Paulo: Cortez, 2002.

OLIVEIRA, O. C. As possibilidades de novos rumos para a educação formal na Ilha de Marambaia - RJ. 129f. Dissertação (Mestrado em Educação) - Instituto de Agronomia, Universidade Federal Rural do Rio de Janeiro, Seropédica, 2009.

PASCHOAL, J. D; MACHADO, M.C .G. A história da Educação Infantil no Brasil: avanços, retrocessos e desafios dessa modalidade educacional. Revista Histedbr On-line, Campinas, n.33, p.78-95, 2009.

PATTO, M.H.S. A produção do fracasso escolar: histórias de submissão e rebeldia. São Paulo: Casa do Psicólogo, 1990. 
POJO, E. C. Travessias educativas em comunidades ribeirinhas da Amazônia. $130 \mathrm{f}$. Dissertação (Mestrado em Educação) - Universidade Metodista de São Paulo, São Bernardo do Campo, 2003.

ROSEMBERG, F. Avaliação de programas, indicadores e projetos em educação infantil. Revista Brasileira de Educação, Rio de Janeiro, n. 16, p. 19-26, 2001.

ROSEMBERG, F. Organizações multilaterais, estado e políticas de educação infantil. Cadernos de Pesquisa, São Paulo, n. 115, p. 25-64, 2002.

ROSSETTI-FERREIRA, M. C.; AMORIM, K. S.; SILVA, A. P. S. Uma perspectiva teóricometodológica para análise do desenvolvimento humano e do processo de investigação. Psicologia: Reflexão e Crítica, Porto Alegre, n.2, v.13, p.281-293, 2000.

ROSSETTI-FERREIRA, M. C.; AMORIM, K. S.; SILVA, A. P. S.; CARVALHO, A. M. A. Rede de significações e o estudo do desenvolvimento humano. Porto Alegre: Artmed, 2004.

ROSSETTI-FERREIRA, M. C.; AMORIM, K. S.; SILVA, A. P. S.; OLIVEIRA, Z. M. R. Desafios metodológicos na perspectiva da rede de significações. Cadernos de Pesquisa, São Paulo, n.133, v.38, p.147-170, 2008.

SAISI, N. B. Educação Infantil e família: uma parceria necessária. Educação: teoria e prática, Rio Claro, n.34, v.20, p.65-85, 2010.

SHANIN, T. A definição de camponês: conceituações e desconceituações - o velho e o novo em uma discussão marxista. Revista NERA, Presidente Prudente, n.7, p.1-21, 2005.

SILVA, A. P. S. (Des) continuidades no envolvimento com o crime: construção de identidade narrativa de ex-infratores. São Paulo: IBCCRIM, 2003.

SILVA, A. P. S.; PASUCH, J. Orientações Curriculares para a Educação Infantil do Campo. In: Anais do I Seminário Nacional: Currículo em Movimento - Perspectivas Atuais. Belo Horizonte, 2010.

SILVA, A. P.; PASUCH, J.; SILVA, J. B. Educação Infantil do Campo. 1. ed. São Paulo: Cortez, 2012. 
SILVA, I. O. De pajem a professora: ambiguidades da formação docente na educação infantil. Paidéia, Belo Horizonte, n. 4, p. 249-275, 2008.

SILVA, I. O.; LUZ, I. R.; FARIA FILHO, L. M. Grupos de pesquisa sobre infância, criança e educação infantil no Brasil: primeiras aproximações. Revista Brasileira de Educação (Impresso), Rio de Janeiro, v. 15, p. 84-97, 2010.

SOUZA. S. J.; KRAMER, S. Educação ou tutela? A criança de 0 a 6 anos. São Paulo: Loyola, 1988.

STRENZEL, G. R. A produção científica sobre educação infantil no Brasil nos programas de pós-graduação em educação. In: $23^{\text {a }}$ Reunião Anual da ANPEd, Caxambu. Anais... Rio de Janeiro: 2000. p.1-12.

TEIXEIRA, S. R. S.; ALVES, J. M. O contexto das brincadeiras das crianças ribeirinhas da Ilha do Combu. Psicologia: reflexão e crítica, Porto Alegre, n.3, v.21, p.374-382, 2008.

VARGAS, S. M. Processos de formação e aprendizagem no meio rural: o continuum famíliaescola. Revista Brasileira de Educação, Rio de Janeiro, n. 24, p.95-106, 2003.

VASCONCELOS, J. F.; SAMPAIO, S. Problemas médico-sociais da infância: o comércio das criadeiras. $1938 . \quad$ Disponível em: <http://www.fcc.org.br/pesquisa/jsp/educacaoInfancia/index.jsp>. Acesso em: 01 out. 2011.

VENDRAMINI, C. R. Educação e trabalho: reflexões em torno dos movimentos sociais do campo. Cadernos Cedes, Campinas, n. 72, v. 27, p. 121-135, 2007.

VIEIRA, L. M. F. Mal necessário: creches no Departamento Nacional da Criança (19401970). Cadernos de Pesquisa, São Paulo, v. 67, p. 3-16, 1988.

VITORIA, T. Representações de educadoras sobre as mães e famílias das crianças da Creche. 121f. Dissertação (Mestrado em Psicologia) - Faculdade de Filosofia, Ciências e Letras de Ribeirão Preto, Universidade de São Paulo, Ribeirão Preto, 1997.

VITORIA, T. As relações Creche e famílias. Perspectiva, Florianópolis, n.31, v.17, p. 45-59, 1999.

VYGOTSKY, L. S. A formação social da mente. São Paulo: Martins Fontes, 1984. 
VYGOTSKY, L. S. A construção do pensamento e da linguagem. Trad. Paulo Bezerra. $2^{\mathrm{a} e d . ~ S a ̃ o ~ P a u l o: ~ E d i t o r a ~ W M F ~ M a r t i n s ~ F o n t e s, ~} 2009$.

WALLON, H. O Papel do outro na consciência do eu. In: WEREBE, M. J. G.; NADELBRULFERT, J. (Orgs). Henri Wallon. São Paulo: Ática, 1986.

WATTE, C. R. A trajetória de vida das famílias do campo que compõem a comunidade escolar do Centro Municipal de Educação Anchieta/SC. In: AUED, B. C., VENDRAMINI, C. R. (Orgs.). Educação do campo: desafios teóricos e práticos. Florianópolis, 2009. p.265-279.

ZAGO, N. Transformações urbanas e dinâmicas escolares: uma relação de interdependência num bairro da periferia urbana. Educação, Sociedade e Culturas, Porto, n.7, p.29-54, 1997. 



\section{APÊNDICES}

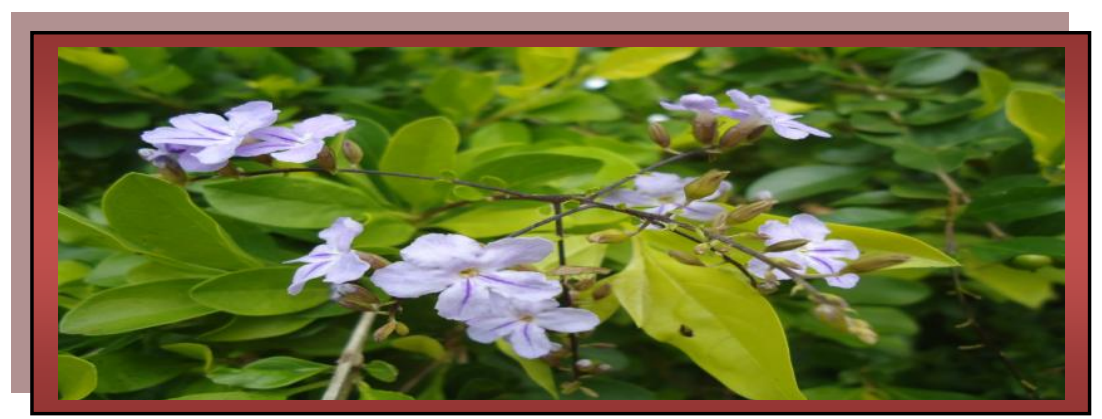





\section{APÊNDICE A}

Roteiro de entrevista com gestores das instituições de Educação Infantil no campo

1) Nome da instituição

2) Localização

3) Horário de funcionamento

4) Histórico

5) Estrutura (número de salas, outros ambientes...). Se tem xerox, internet, data-show....

6) Vinculação com a Prefeitura Municipal (rede direta ou conveniada)

7) Como se dá a relação com a Prefeitura Municipal (visitas, envio de documentos,...)

8) Outros parceiros

9) Recursos Financeiros

10) População atendida

- Faixa etária das crianças

- Número de crianças

- Proporção criança e professor

- Rotatividade

- Famílias (origem, ocupação, nível socioeconômico)

- Relação com a família

11) Transporte das crianças (como chegam à instituição, distância)

12) Profissionais

- Número

- Formação/Atividades desenvolvidas

- Local onde residem

13) Se há demanda para ampliação do serviço (vagas e modalidades de atendimento)

14) Se há a ida de crianças do campo para instituições da cidade. Se sim, de qual faixa etária.

15) Se há vantagens e/ou desvantagens do atendimento da criança no campo

16) Se há facilidades e/ou dificuldades do atendimento da criança no campo

17) Dados pessoais e profissionais (nome, cargo, tempo na instituição, formação)

18) Outras observações 


\section{APÊNDICE B}

\section{Roteiro de entrevista com as famílias}

\section{1) A família}

- História - origem, trajetórias.

- A vida e a relação com o campo e a cidade - Sentido de campo e cidade.

- Membros e ocupações.

- O cotidiano da família (Relato de um dia de semana e de um dia do final de semana).

- Sentidos sobre família.

\section{2) As crianças}

- Número e faixa etária

- O cotidiano das crianças, mais especificamente as pequenas.

- Responsáveis pelo seu cuidado e educação.

- Sentidos sobre cuidar e educar.

\section{3) A Escola}

\subsection{A entrada na instituição}

- Conhecimento da Escola e o primeiro contato.

- A entrada da criança na Escola - Como foi? Quais os motivos para a realização da matrícula? A criança entrou na Escola na idade desejada pela família? Ou desejavam que esta entrada ocorresse antes ou depois?

- O que sentiram quando a criança entrou na Escola.

- A vaga - Critérios da Escola para ingresso, presença ou não de lista de espera, se há demanda na comunidade para atendimento de crianças na Educação Infantil, se considera que tem de existir tal atendimento para todas as crianças pequenas ( 0 a 5 anos).

\subsection{O transporte}

- Hora de saída e chegada da criança em casa.

- Opinião sobre o transporte.

\section{3. $O$ atendimento}

- A Escola: objetivos/papel e atividades realizadas. Sentidos sobre a Educação Infantil.

- Opinião sobre o atendimento oferecido: atividades, estrutura e profissionais.

\subsection{Relação Escola e família}

- Há encontros? Se sim: quando, como e onde ocorrem.

- Famílias vão à Escola? Se sim: qual o transporte?

- Opinião sobre a relação.

\subsection{Avaliação, Sentimentos e Ideais}

- Vantagens e desvantagem da ida da criança para a Escola (Para a criança, família e Escola).

- O que sente hoje quando a criança vai para a Escola.

- O que seria uma instituição/um atendimento ideal.

\section{4) Dados pessoais}




\section{APÊNDICE C}

\section{Roteiro de entrevista com os profissionais da Escola Flamboyant}

\section{1) História profissional}

- Trajetória profissional - Formação, quando começou a trabalhar na EI.

- A ida para a Escola do campo. Onde mora atualmente.

- Cargo ocupado na Escola.

- A relação com o campo e a cidade - Sentido de campo e cidade.

\section{2) A Escola}

- História da Escola e do atendimento na Educação Infantil.

- Objetivos/papel da Escola.

\section{3) A Educação Infantil}

- A vaga: Critérios de ingresso, presença ou não de lista de espera, se há demanda/para qual faixa etária, se considera que tem de existir tal atendimento para todas as crianças pequenas ( 0 a 5 anos).

- Número de crianças matriculadas.

- Atividades realizadas e objetivos. Sentidos sobre a Educação Infantil.

- Se há avaliação das crianças. Se sim, descrever.

- Opinião sobre o atendimento oferecido: atividades realizadas, estrutura, profissionais, currículo, alimentação e formas de avaliação.

- Semelhanças e diferenças com trabalho já desenvolvido/em desenvolvimento em outra instituição com crianças pequenas. Opinião sobre esta (não)diferenciação.

-Sentidos sobre o cuidar e o educar.

\section{4) As crianças}

- A relação com as crianças. Sentidos sobre infância.

- O que facilita e dificulta esta relação.

- Há rotatividade? Se sim, por quê?

\section{5) O transporte}

- Hora de saída e chegada da criança em casa.

- Opinião sobre o transporte.

\section{6) As famílias}

- Como são e como cuidam e educam as crianças. Sentidos sobre família.

- A relação com as famílias - como ocorre (local, periodicidade e objetivo). Opinião sobre esta relação.

- O que facilita e dificulta esta relação.

\section{7) Avaliação e ideais}

- O que facilita e/ou dificulta o atendimento da criança da Educação Infantil na Escola do campo.

- Vantagem e desvantagem da ida da criança para a Escola (Para a criança, família e Escola).

- O que seria uma instituição/um atendimento ideal.

\section{8) Dados pessoais}




\section{APÊNDICE D \\ Termo de Consentimento Livre e Esclarecido \\ (Gestores e profissionais da educação)}

$\mathrm{Eu}$, da instituição

aceito participar da pesquisa intitulada $\boldsymbol{A}$ relação entre a Educação Infantil e as famílias do campo, desenvolvida por Luciana Pereira de Lima, pós-graduanda da Faculdade de Filosofia Ciências e Letras de Ribeirão Preto, sob orientação da Profa. Dra. Ana Paula Soares da Silva. Fui informado(a) que esta pesquisa tem como objetivo investigar condições de atendimento da criança do campo na Educação Infantil e a relação entre as instituições de Educação Infantil no campo e as famílias.

Fui esclarecido(a) de que a pesquisa utilizará a análise de dados obtidos durante visitas à instituição que irão ser realizadas pela pesquisadora. Estas visitas terão como objetivo o conhecimento da instituição pela pesquisadora.

Fui informado(a) de que a pesquisa utilizará a análise de entrevistas com profissionais da instituição que serão gravadas em fita cassete e/ou aparelho digital.

Fui esclarecido(a) de que a participação na pesquisa não traz riscos aos participantes e que irão ser respeitadas as normas éticas quanto à identificação nominal dessa instituição e de seus profissionais, garantindo-se o anonimato.

A minha participação nesta pesquisa é feita por um ato voluntário, o que me deixa ciente de que a pesquisa não me trará nenhum apoio financeiro ou despesa, sendo possível, a qualquer momento, interromper a participação sem que essa decisão traga quaisquer consequências.

Todas as minhas questões quanto à pesquisa foram respondidas, e a pesquisadora colocou-se à disposição para esclarecer quaisquer dúvidas que eu tiver em qualquer momento da pesquisa.

Estou ciente de que este tipo de pesquisa pode contribuir para o planejamento de ações que visem à melhoria da Educação Infantil no campo. Por isso, autorizo a divulgação dos dados obtidos, para fins acadêmicos e científicos, desde que seja resguardada a minha identidade.

Participante:

de de

Pesquisadora:

Faculdade de Filosofia, Ciências e Letras - USP/ RP

Av. Bandeirantes, 3900, Bloco 3 - sala 1 - CINDEDI

Ribeirão Preto - SP

Tels: (16) 3602-4549

(34) $9942-0187$ 


\section{Termo de Consentimento Livre e Esclarecido (Gestores e profissionais da educação)}

$\mathrm{Eu}$, aceito participar da pesquisa intitulada $\boldsymbol{A}$ relação entre a Educação Infantil e as famílias do campo, desenvolvida pela aluna Luciana Pereira de Lima e orientada pela Profa. Dra. Ana Paula Soares da Silva da Faculdade de Filosofia Ciências e Letras de Ribeirão Preto - Universidade de São Paulo. Estou ciente de que esse tipo de pesquisa pode contribuir para o planejamento de ações que visem à melhoria da Educação Infantil no campo. Por isso, autorizo a divulgação dos dados obtidos, para fins acadêmicos e científicos, desde que seja resguardada a minha identidade.

As informações levantadas comporão um banco de dados do Centro de Investigações sobre Desenvolvimento Humano e Educação Infantil (CINDEDI-FFCLRP/USP), do qual a pesquisadora faz parte. Foi garantido que o acesso a esse banco de dados é de exclusividade dos pesquisadores desse Centro e, por esse motivo, autorizo também a utilização dos dados em outras pesquisas, desde que estejam asseguradas as mesmas garantias éticas e que o projeto seja submetido ao Comitê de Ética em Pesquisa.

Participante:

de

de

Pesquisadora:

Faculdade de Filosofia, Ciências e Letras - USP/ RP

Av. Bandeirantes, 3900, Bloco 3 - sala 1 - CINDEDI

Ribeirão Preto - SP

Tels: (16)3602-4549

(34) $9942-0187$ 


\section{APÊNDICE E \\ Termo de Consentimento Livre e Esclarecido (Famílias)}

$\mathrm{Eu}$,

na condição de da instituição

aceito participar da pesquisa intitulada $A$ relação entre a Educação Infantil e as famílias do campo, desenvolvida por Luciana Pereira de Lima, pós-graduanda da Faculdade de Filosofia Ciências e Letras de Ribeirão Preto, sob orientação da Profa. Dra. Ana Paula Soares da Silva.

Fui esclarecido(a) de que a pesquisa utilizará a análise de dados obtidos durante visitas às famílias que irão ser realizadas pela pesquisadora. Estas visitas terão como objetivo o conhecimento das famílias pela pesquisadora.

Fui informado(a) de que a pesquisa utilizará a análise de entrevistas com as famílias, que serão gravadas em fita cassete e/ou aparelho digital.

Fui esclarecido(a) de que a participação na pesquisa não me trará danos de qualquer natureza, bem como ganhos ou despesas financeiras.

Fui informado(a) de que a minha participação é voluntária e que posso, a qualquer momento, parar de participar da pesquisa, sem que isso traga qualquer consequência.

Dessa forma, aceito participar desta pesquisa e autorizo a publicação e divulgação dos dados obtidos pela pesquisadora, desde que não haja a citação de meu nome e de outros nomes mencionados durante a pesquisa.

Todas as minhas questões em relação à pesquisa foram respondidas, e a pesquisadora colocouse à disposição para esclarecer quaisquer dúvidas que eu tiver em qualquer momento da pesquisa.

Participante:

de

de

Pesquisadora:

Faculdade de Filosofia, Ciências e Letras - USP/ RP

Av. Bandeirantes, 3900

Bloco 3 - sala 1 - CINDEDI

Ribeirão Preto - SP

Tels: (16) 3602-4549

(34) $9942-0187$ 


\section{Termo de Consentimento Livre e Esclarecido (Famílias)}

$\mathrm{Eu}$, aceito participar da pesquisa intitulada $\boldsymbol{A}$ relação entre a Educação Infantil e as famílias do campo, desenvolvida pela aluna Luciana Pereira de Lima e orientada pela Profa. Dra. Ana Paula Soares da Silva da Faculdade de Filosofia Ciências e Letras de Ribeirão Preto - Universidade de São Paulo. Estou ciente de que este tipo de pesquisa pode contribuir para o planejamento de ações que visem à melhoria da Educação Infantil no campo. Por isso, autorizo a divulgação dos dados obtidos, para fins acadêmicos e científicos, desde que seja resguardada a minha identidade.

Fui informado(a) de que as informações obtidas na pesquisa comporão um banco de dados do Centro de Investigações sobre Desenvolvimento Humano e Educação Infantil (CINDEDI-FFCLRPUSP), do qual a pesquisadora faz parte. Foi garantido que o acesso a esse banco de dados é de exclusividade dos pesquisadores desse centro e, por esse motivo, autorizo também a utilização dos dados em outras pesquisas, desde que estejam asseguradas as mesmas garantias éticas e que o projeto seja submetido ao Comitê de Ética em Pesquisa.

Participante:

de de

Pesquisadora:

Faculdade de Filosofia, Ciências e Letras - USP/ RP

Av. Bandeirantes, 3900

Bloco 3 - sala 1 - CINDEDI

Ribeirão Preto - SP

Tels: (16) 3602-4549

(34) $9942-0187$ 
